\title{
Geochemical Signatures as a Tool for Vermiculite Provenance Determination
}

\author{
Karen E. Wright
}

Carl D. Palmer

September 2008

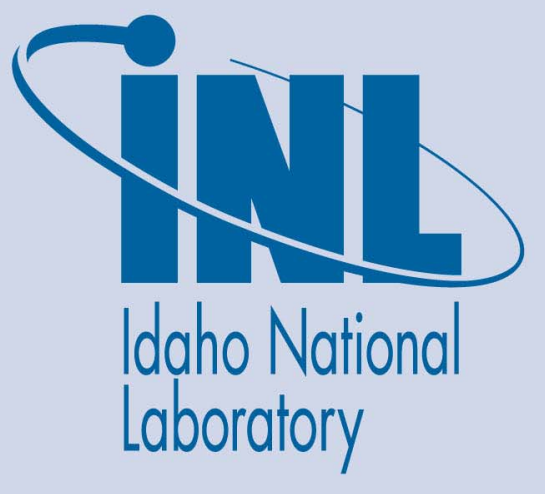

The INL is a U.S. Department of Energy National Laboratory operated by Battelle Energy Alliance 


\title{
Geochemical Signatures as a Tool for Vermiculite Provenance Determination
}

\author{
Karen E. Wright \\ Carl D. Palmer
}

September 2008

\section{Idaho National Laboratory \\ Idaho Falls, Idaho 83415}

http://www.inl.gov

\author{
Prepared for the \\ U.S. Environmental Protection Agency \\ Region 10 \\ and for the \\ U.S. Department of Energy \\ Under DOE Idaho Operations Office \\ Contract DE-AC07-05ID14517
}




\section{DISCLAIMER}

This information was prepared as an account of work sponsored by an agency of the U.S. Government. Neither the U.S. Government nor any agency thereof, nor any of their employees, makes any warranty, expressed or implied, or assumes any legal liability or responsibility for the accuracy, completeness, or usefulness, of any information, apparatus, product, or process disclosed, or represents that its use would not infringe privately owned rights. References herein to any specific commercial product, process, or service by trade name, trade mark, manufacturer, or otherwise, does not necessarily constitute or imply its endorsement,

recommendation, or favoring by the U.S. Government or any agency thereof. The views and opinions of authors expressed herein do not necessarily state or reflect those of the U.S. Government or any agency thereof. 


\section{ACKNOWLEDGEMENTS}

We would like to thank Mr. John Barich, EPA Region 10, for providing the funding for this work. We would like to thank Mr. Jed Januch of EPA Region 10 for providing us with product samples, and for coordinating the efforts of EPA Region 8 and 4 to provide us with samples. We would also like to express our gratitude to Mr. Gary Taylor of the South Carolina Geological Survey for providing us with samples from the Enoree area. Without his assistance this work would not be possible. Finally we would like to thank Dr. Scott Hughes and Myles Miller from Idaho State University for providing expertise with regard to neutron activation analysis, and Ms Diane Johnson Cornelius, of Washington State University for her expertise with regard to X-ray fluorescence spectroscopy. 



\section{ABSTRACT}

Thirty-eight samples of known origin (China, Libby MT, South Africa, South Carolina) and 6 vermiculite product samples of unknown origin were analyzed for major and trace elements, including rare earth elements to determine the feasibility of distinguishing the provenance of the samples based upon a geochemical signature. Probability plots suggest that two of the four groups (Libby, South Carolina) were comprised of two subgroups. Results of hierarchical cluster analysis are highly sensitive to the linkage method chosen. Ward's method is the most useful for this data and suggests that there are five groups within the data set (South African samples, two subsets of the Libby samples, a subset of the South Carolina samples, and a second subset of the South Carolina samples combined with the China samples). Similar results were obtained using k-cluster analysis. Neither clustering method was able to distinguish samples from China from the South Carolina samples. Discriminant analysis was used on a four-category model comprised of the original four groups and on a six-category model comprised of the five categories identified from the cluster analysis but with the China samples grouped into a sixth category. The discriminant/classification model was able to distinguish all of the groups including the China samples from one another for both the four- and six-category models with $100 \%$ of the samples properly classified. The 6 unknown product samples were classified with a probability of consistency of $99 \%$. Both discriminant models were also run with a subset of our analyte set to be consistent with the smaller Gunter et al., (2005) analyte set. Twenty vermiculite samples (nine of known origin and eleven of unknown origin) from their study were classified based on our discriminant models with the reduced set of analytes. Of the twenty samples, Gunter et al. (2005) was able to classify 16 with cluster analysis while our 4-category discriminant analysis model allowed us to classify all twenty. Of the 16 samples Gunter et al. (2005) classified using cluster analysis, all but one sample was assigned the same classification by our 4category model. Of the nine samples with known origin, all were correctly classified. Similar results were obtained for the six-category model. Comparison of the plots of the canonical roots, the Wilks' $\mathrm{L}$, and the square Mahalanobis distances suggest the full analyte set provides better discrimination of the groups than the reduced analyte set. The six-category model is more consistent with the results of the probability plots and the cluster analysis. Discriminant analysis of geochemical data from vermiculite ore is a powerful technique for determining the ore's provenance. 


\section{CONTENTS}

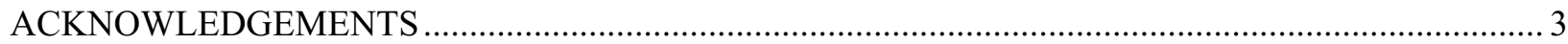

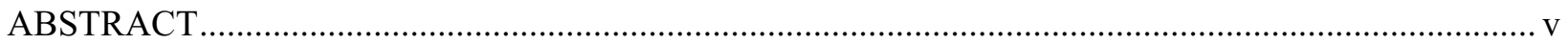

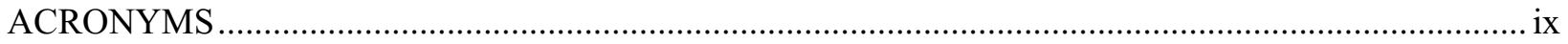

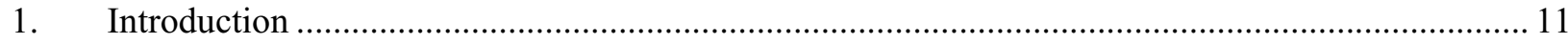

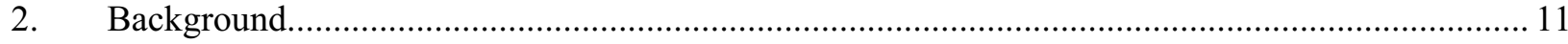

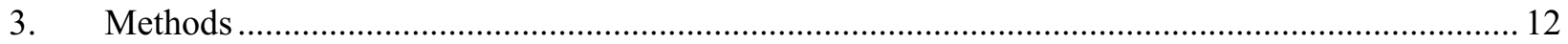

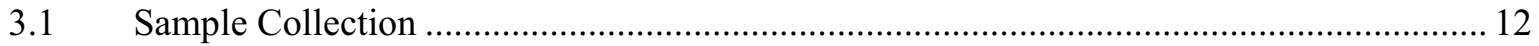

3.2 Sample Preparation and Analysis ...................................................................... 12

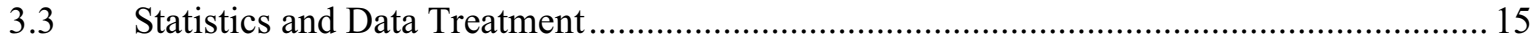

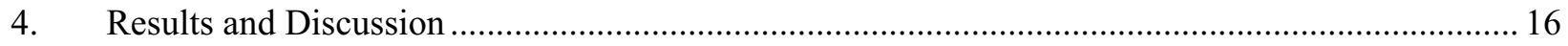

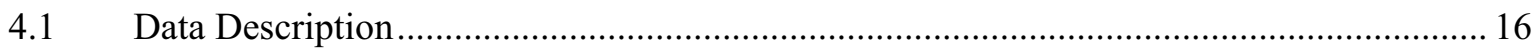

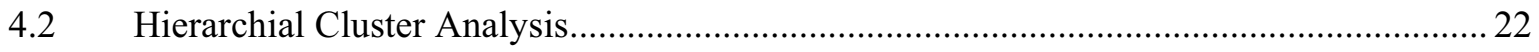

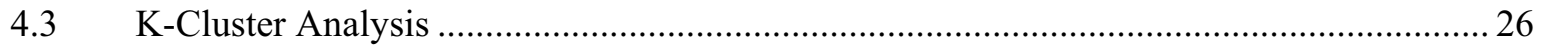

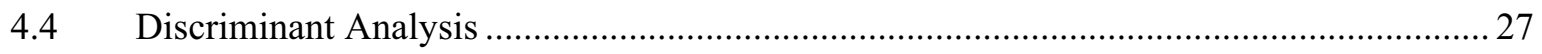

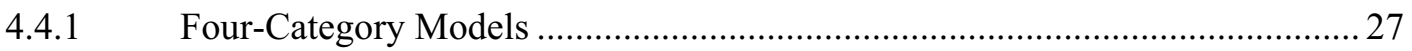

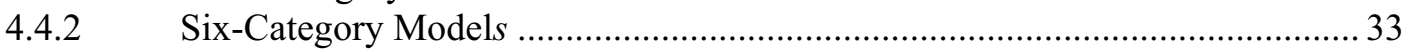

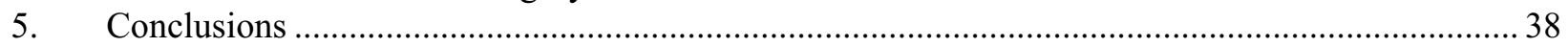

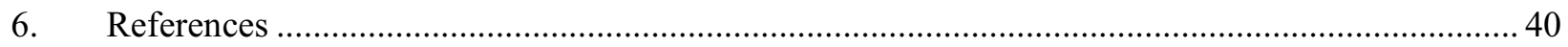

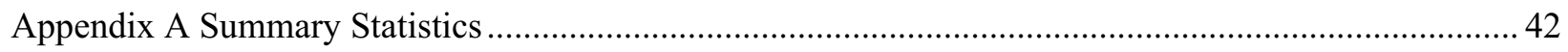

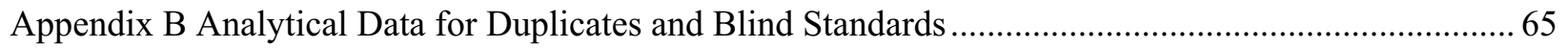

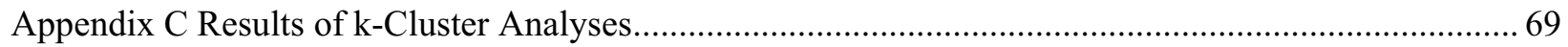

Appendix D Results of Four-Category Discriminant Analyses .............................................................. 95

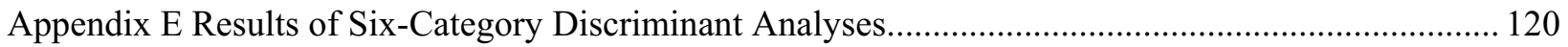




\section{FIGURES}

Figure 1. Spider diagram showing all vermiculite samples normalized to primitive mantle (Sun and McDonough, 1989).

Figure 2. Cluster diagrams using single linkage (A), complete linkage (B), unweighted pair-group average (C), and Ward's method (D). All of the methods used Euclidean distances. All ores and products analyzed in this study are shown. Samples of known origin have their sample names preceded by a location designation $(\mathrm{SC}=$ South Carolina, $\mathrm{SA}=$ South Africa, $\mathrm{CH}=\mathrm{China}, \mathrm{L}=\mathrm{Libby}$, $\mathrm{P}=$ product), although a priori knowledge of the sample origin has no effect on the cluster analysis. 25

Figure 3. Plot of $\mathrm{c}$ versus number of clusters used in the k-cluster analysis. Maximum values of $\mathrm{c}$ reflect the "best" model. 27

Figure 4. Scatter plots of canonical scores for data from the four-category method. 30

Figure 5. Scatter plots of canonical scores for data from six-category model. Ellipses define the compositional fields of each category based on their roots.

\section{TABLES}

Table 1. Sample names, sources and brief description

Table 2. Chemical analysis of vermiculite samples. See Table 1 for sample descriptions and locations. 18

Table 3. Table of highly correlated elements. Elements in bold were used in cluster analysis while the other correlated elements were removed from the analysis.

Table 4. Seeds used in the k-cluster analysis.

Table 5. Discriminant function analysis summary for the four category model.

Table 6. Chi-square tests for successive roots removed for the four-category model. .28

Table 7. Raw and standardized discriminant function coefficients for the four category model

Table 8 . Coefficients for the classification functions for the four-category model.

Table 9. Classification probabilities for the six products for the four-category model

Table 10. Posteriori classification probabilities for the samples analyzed by Gunter et al. (2005) using discriminant analysis. $\mathrm{Li}=$ samples from Libby; at $=$ attic samples; $\mathrm{ga}=$ garden products; $\mathrm{SA}=$ samples from South Africa, and $\mathrm{SC}=$ samples from South Carolina.

Table 11. Discriminant function analysis summary for six-category model. 34

Table 12. Chi-square tests for successive roots removed for the six-category model. 34 
Table 13. Raw and standardized discriminant function coefficients for six-category model.

Table 14. Coefficients for the classification functions for the six-category model.

Table 15. Posteriori calculations of classification probabilities for the six products and SA GS-1 using the six-category model. 


\section{ACRONYMS}

INL Idaho National Laboratory

NAA Neutron Activation Analysis

NIST National Institute for Standards and Testing

ppm Parts per million $(\mathrm{mg} / \mathrm{kg})$

REE Rare Earth Element

SCGS South Carolina Geological Survey

USEPA United States Environmental Protection Agency

USGS United States Geological Survey

XRF X-ray Fluorescence Spectroscopy 


\section{Introduction}

Vermiculite is chemically similar to tri-octahedral smectites and micas, and structurally similar to phlogopite. It can be found as an alteration product of phlogopite or biotite, in a contact region between siliceous intrusives and mafic rocks, or in association with carbonatites (Deer et. al, 1993). When heated rapidly above $900^{\circ} \mathrm{C}$, generation of steam results in "exfoliation"-- a process whereby the mineral expands perpendicular to its cleavage planes, resulting in a product with excellent insulating and absorption properties (Potter, 2000).

Vermiculite was used extensively as attic insulation, building materials, packing materials and gardening adjuncts. For example, the United States Environmental Protection Agency (EPA) states that 940,000 homes in the USA may have vermiculite as attic insulation (EPA, 1985). From 1924-1990, more than half of the world's vermiculite supply came from Libby, Montana (USGS, 2006). Although vermiculite is no longer mined in Libby, it is still mined in the U.S. W.R. Grace \& Co. currently mines vermiculite near Enoree, S.C., and Virginia Vermiculite Ltd. mines vermiculite in Louisa County, VA and operates a vermiculite subsidiary near Woodruff, S.C. In addition, substantial amounts of vermiculite are imported from the northern Transvaal region in South Africa, and China's world supply continues to grow (Potter, 2000).

In 1999, Libby came to national attention when the Seattle Post-Intelligencer (Schneider, 1999) revealed the extent of lung-related illnesses both among workers and within the community, as a result of asbestos contamination of the vermiculite. A 2002 Agency for Toxic Substances and Disease Registry study (ATSDR, 2002) found that asbestosis mortality in the Libby area was 40 times higher than the rest of Montana and 60 times higher than the rest of the United States. Because Libby vermiculite can still be found (primarily as attic insulation), it would be useful to be able to distinguish the source (provenance) of vermiculite in an unknown sample. In addition, if data surfaces demonstrating that a particular mine is contaminated with asbestos, the ability to distinguish the source of an unknown sample would aid in determining relative risk, without the cost and complexity of asbestos sampling.

The objective of the current study is to determine if the provenance of vermiculite samples can be identified from their geochemical composition and to identify the combination of analytes that can best discriminate the provenances from one another.

\section{Background}

A 2001 feasibility study performed by EPA (Frank and Edmund, 2001) suggested several different approaches to the use of geochemical tracers to determine ore provenance. These include the use of accessory minerals, major, minor, and trace elements, and isotopic ratios.

Gunter and Singleton (2003) used whole rock chemical analysis for vermiculite provenance determination and found that Libby samples tend to be high in $\mathrm{Cr}, \mathrm{V}, \mathrm{Ba}$, and FeO. Williams and others (2003) suggested Libby vermiculite samples might be distinguished from vermiculites from other locations using $\mathrm{x}$-ray diffraction due to differences in relative intensities of 10,12, and 14 angstrom peaks. In a study where samples from Libby, South Africa, South Carolina, and Virginia were compared to vermiculite products using electron microprobe data, Lowers and Meeker (2004) found that although samples from South Africa were distinct, Libby and South Carolina samples were more difficult to distinguish. This result is important because South Carolina is a major vermiculite supplier and its ore is reported to contain fibrous tremolite (Libby, 1975). Gunter and others (2005) used cluster analysis (average linkage) 
on a data set that included 8 major element and 10 trace elements to distinguish ores from Libby, South Carolina, China, and South Africa.

Because rare-earth elements (REEs) commonly reflect the mineralogy and petrogenesis of the ore body, a statistical approach that includes these elements may be diagnostic of the ore's provenance. Boettcher (1967) described the mineralogy of the Rainy Creek Complex of Libby, from which Libby vermiculite was extracted, as containing vermiculite, biotite, apatite, pyroxene and tremolite, with trace amounts of sphene, zircon, carbonate, feldspar and microcline. Vermiculite ore bodies from South Carolina were described by Libby (1975) as containing vermiculite/hydrobiotite, biotite, augite, tremolite, microcline, apatite, tremolite, and talc with minor amounts of sphene/rutile, microperthite, zircon, and monazite. The Palabora complex in South Africa is mined not only for vermiculite, but also contains economic quantities of apatite, magnetite, baddeleyite $\left(\mathrm{ZrO}_{2}\right)$, uranothorianite, linnaeite (for cobalt), and trace precious metals (Guilbert and Park, 1986). Mineralogy of the areas where the China samples were collected was not available to us.

In the current study, thirty eight vermiculite rock samples of known origin and six product samples are analyzed for 10 major and 28 trace elements including REEs. Cluster analysis is used to determine groupings of the samples, while discriminant/classification analysis is used to identify linear combinations of elements that can best discriminate the various sources of the samples. The results of these calculations allow us to classify product samples supplied to us by EPA and samples reported by Gunter et al. (2005).

\section{Methods}

\subsection{Sample Collection}

Vermiculite samples were obtained from several sources. The U.S. Geological Survey (USGS) provided 13 samples from the A.L Bush collection including samples from Libby (3), South Carolina (2), South Africa (5), and China (3). Region 4 EPA provided three samples from South Africa and one South Carolina sample processed at Palmetto Vermiculite. Region 8 EPA sent 11 samples obtained from Libby. The South Carolina Geological Survey (SCGS) sent 10 samples from the Enoree, S.C. region. Finally, EPA Region 10 provided 6 vermiculite product samples (Table 1).

All the samples were "grab" samples. Some came from active or closed mining sites (e.g. Libby); others came from exposed outcrop (e.g., some samples from Enoree). No attempts were made to remove accessory minerals or otherwise alter the samples, except to reduce particle size.

\subsection{Sample Preparation and Analysis}

Because samples came from different sources and had different analytical requirements, several different preparation steps were employed. Samples provided by SCGS were easily pulverized to $<200$ mesh following about 2 minutes of grinding in a shatterbox using a zirconia grinding dish. The remaining vermiculite samples consisted of large flakes (and in the case of product, large exfoliated flakes). Methods used to reduce the particle size of these samples depended on the analytical method used. Splits $(3 \mathrm{~g})$ intended for neutron activation analysis (NAA) were cut by steel bladed scissors to reduce the flakes to $<2 \mathrm{~mm}$ across. Splits (10-15g) intended for X-ray fluorescence (XRF) were pulverized by the GeoAnalytical Lab at Washington State University using a tungsten carbide swingmill. Loss on ignition (LOI) was measured on sample splits heated at $750^{\circ} \mathrm{C}$. This temperature may not release all structural 
water in vermiculite, but was chosen to minimize potential reaction with silica crucibles (Diane Johnson, personal communication).

All samples were analyzed for trace elements using NAA. Samples were irradiated at Oregon State University and counted by the Laboratory for Environmental Geochemistry at Idaho State University using methods described by Wright (1998). With the exception of samples from the USGS A.L. Bush collection, all samples were prepared and analyzed using XRF by the GeoAnalytical Lab at Washington State University using methods described by Johnson et. al (1999). Briefly, this involved mixing powdered samples with lithium tetraborate in a 1:2 ratio and heating in a graphite crucible at $1000^{\circ} \mathrm{C}$ for 5 minutes. Upon cooling, the samples were crushed and reground in a swingmill and re-fused for 5 minutes. Following cooling, resultant glass beads were polished with 600 grit silicon carbide and cleaned in an ultrasonic cleaner. 
Table 1. Sample names, sources and brief description

\begin{tabular}{|c|c|}
\hline Sample Name & Source/Description \\
\hline \multicolumn{2}{|c|}{$\begin{array}{l}\text { USGS Samples from the } \\
\text { A.L. Bush Collection }\end{array}$} \\
\hline GS2 & Libby AB3, crude vermiculite \\
\hline GS4 & Libby AB4, no.1 sorted vermiculite \\
\hline GS10 & Libby AB111, no. 0 sorted vermiculite \\
\hline GS15 & $\begin{array}{l}\text { South Carolina traveler's rest ore with } 10 \% \text { gangue donated by G. Breit, } \\
1958\end{array}$ \\
\hline GS11 & South Carolina no. 3c crude ore from 1967 or 1971 \\
\hline GS1 & South Africa AB 35, crude no. 4 ore from Palabora \\
\hline GS18 & South Africa AB 117, classified vermiculite ore, no. 3 sort, Palabora \\
\hline GS17 & South Africa AB 118, classified vermiculite ore, no. 2 sort, Palabora \\
\hline GS3 & South Africa AB119, classified vermiculite ore, no. 1 sort, Palabora \\
\hline GS13 & South Africa AB 120, classified vermiculite ore, no. 0 sort, Palabora \\
\hline GS12 & China AB 36, Xinchang, processed vermiculite ore, $2.0-4.0 \mathrm{~mm}$ \\
\hline GS16 & China AB 37, Xinchang, processed vermiculite ore, $0.5-2.0 \mathrm{~mm}$ \\
\hline GS7 & China AB 38, Xinchang, crude vermiculite ore \\
\hline \multicolumn{2}{|c|}{$\begin{array}{l}\text { Samples provided by } \\
\text { EPA Region } 4\end{array}$} \\
\hline PVC1 & South Africa, processed by Palmetto Vermiculite \\
\hline PVC2 & South Africa, processed by Palmetto Vermiculite \\
\hline $\mathrm{PVC} 3$ & South Africa, processed by Palmetto Vermiculite \\
\hline PVC5 & South Carolina, processed by Palmetto Vermiculite \\
\hline \multicolumn{2}{|c|}{$\begin{array}{l}\text { Samples provided by } \\
\text { EPA Region } 8\end{array}$} \\
\hline $1 \mathrm{~A}$ & Libby grab samples \\
\hline $2 \mathrm{~A}$ & Libby grab samples \\
\hline $3 \mathrm{~A}$ & Libby grab samples \\
\hline $4 \mathrm{~A}$ & Libby grab samples \\
\hline $5 \mathrm{~A}$ & Libby grab samples \\
\hline $6 \mathrm{~A}$ & Libby grab samples \\
\hline $7 \mathrm{~A}$ & Libby grab samples \\
\hline $8 \mathrm{~A}$ & Libby grab samples \\
\hline $9 \mathrm{~A}$ & Libby grab samples \\
\hline $10 \mathrm{~A}$ & Libby grab samples \\
\hline $11 \mathrm{~A}$ & Libby grab samples \\
\hline \multicolumn{2}{|c|}{$\begin{array}{l}\text { Samples provided by } \\
\text { South Carolina } \\
\text { Geological Survey }\end{array}$} \\
\hline SC2 & Enoree area grab samples \\
\hline $\mathrm{SC} 3$ & Enoree area grab samples \\
\hline $\mathrm{SC} 4$ & Enoree area grab samples \\
\hline SC5 & Enoree area grab samples \\
\hline SC6 & Enoree area grab samples \\
\hline SC7 & Enoree area grab samples \\
\hline SC8 & Enoree area grab samples \\
\hline SC9 & Enoree area grab samples \\
\hline SC10 & Enoree area grab samples \\
\hline SC11 & Enoree area grab samples \\
\hline \multicolumn{2}{|c|}{$\begin{array}{l}\text { Product samples } \\
\text { provided by EPA Region } \\
10\end{array}$} \\
\hline P1 & Zonolite Chemical Packaging Vermiculite Product \\
\hline P2 & Thermorock Vermiculite Product \\
\hline P3 & Zonolite Industrial LAB Product \\
\hline P4 & Zonolite Industrial SPU Product \\
\hline P5 & Zonolite Plaster Aggregate Product \\
\hline P6 & Stronglite Fine Vermiculite Product \\
\hline
\end{tabular}




\subsection{Statistics and Data Treatment}

Major element data was normalized on an anhydrous basis (sum of major elements normalized to the sum of major elements plus the LOI) prior to statistical analysis or data plotting. Data gathered from the different sources and analytical procedures (NAA and XRF) were compiled into a single database for statistical analysis. X-ray fluorescence data was used for major element data. Samples provided by SCGS and EPA were analyzed by XRF by Washington State University, while the USGS provided XRF data for the A.L. Bush samples. Trace element data for Ce, Co, Cr, Eu, Hf, La, Lu, Nd, Sc, Sm, Ta, Tb, $\mathrm{Th}$, and $\mathrm{Yb}$ were obtained using NAA. $\mathrm{Ba}, \mathrm{Cu}, \mathrm{Ga}, \mathrm{Nb}, \mathrm{Ni}, \mathrm{Pb}, \mathrm{Rb}, \mathrm{Sr}, \mathrm{U}, \mathrm{V}, \mathrm{Y}, \mathrm{Zn}$ and $\mathrm{Zr}$ (Table 2) were obtained using X-ray fluorescence. In some cases (e.g., $\mathrm{Pb}$ ), data from both the USGS for their samples, and from Washington State University for the remaining samples were used. Thus, two different detection limits are present for the same element, depending on where the analysis was performed. Some analytes, such as $\mathrm{Ba}$, were duplicated with NAA and XRF analyses. When such duplication occurred, the decision to choose data from one technique versus the other was based on the accuracy of analyses of USGS schist standard SDC-1 and NIST coal-fly ash standard 1633-b using each technique (Appendix B). When the accuracy of the two techniques was similar, the technique with the lower detection limit was chosen.

Prior to statistical analysis, data was ln-transformed to render the data normally distributed and to reduce the influence of elements measured with different units (e.g. major elements expressed as weight percent and trace elements expressed as parts-per-million). This prevents elements such as $\mathrm{Ba}$, which can be as high as $4000 \mathrm{ppm}$, from dominating the differences between populations. Statistical analyses were performed on the transformed data set using Statistica v. 7.1(Statsoft, 2006). Not all analyzed elements were included in the statistical analysis. Zirconium and hafnium were excluded because samples pulverized with the zirconia grinder could be contaminated with these elements. Elements for which any of the samples were below the detection limit of the analytical method were excluded. This includes $\mathrm{P}_{2} \mathrm{O}_{5}, \mathrm{Eu}, \mathrm{Lu}, \mathrm{Nd}, \mathrm{Nb}, \mathrm{Pb}, \mathrm{Ta}, \mathrm{Tb}, \mathrm{Th}, \mathrm{U}, \mathrm{Y}$ and $\mathrm{Yb}$. Some elements were eliminated from the statistical analysis because they had properties that would skew the statistical analysis. Elements that are highly correlated can dominate the way likeness is measured (McPherson, 2001). Thus, a Pearson correlation matrix of the ln-transformed data was calculated. Another consideration to the validity of the results of the statistical analysis is the correlation of the variances (standard deviations) with the means across the categories (Statsoft, 2006). Such correlations can result in spurious statistical significance. To test for this possibility, Pearson product moment correlations between the group means and the group variance were calculated for each of the variables used in the analysis. All of the variables had insignificant correlations ( $\mathrm{p}>0.05)$ except for $\mathrm{Rb}(\mathrm{p}=0.00313), \mathrm{Sr}(\mathrm{p}=0.0266)$, and $\mathrm{MgO}(\mathrm{p}=0.0428)$. Therefore $\mathrm{Mg}, \mathrm{Sr}$, and $\mathrm{Rb}$ were not used in further statistical analyses.

Cluster analysis was conducted using both hierarchical and non-hierarchical methods. The number of elements in the analyses was reduced by choosing a single element from groups of correlated elements with correlation coefficients $>0.7$. For the tree clustering analysis (hierarchical), four different agglomeration techniques were applied: single linkage, complete linkage, unweighted pair-group average, and Ward's method. In all cases, a Euclidean distance measure was applied. For the k-cluster analysis (non-hierachial), four sets of seeds were tested corresponding to 4, 5,6, and 7 clusters. The choice of the number of clusters is based on the results of the hierarchical analysis. Additional tests are conducted based on the same seeds used in the five-cluster model plus an additional cluster using each of the China samples as seeds.

To determine which variables best differentiate vermiculite groups, discriminant analysis was performed using the module in the Statistica software package (Statsoft, 2006). The discriminant analysis was performed on the data set using two different sets of categories. The first set is a four-category model 
based on the original grouping of the samples: Libby Montana (L), South Carolina (SC), South Africa (SA), and China $(\mathrm{CH})$. The second set is a six-category mode which is based on the five categories identified in the cluster analysis (two categories from Libby, L1 and L2; one from South Africa, SA; two from South Carolina, SC1 and SC2 ) but with the China samples grouped into a sixth category $(\mathrm{CH})$.

Both the four-category and the six-category model were analyzed using two subsets of the 38 measured analytes. For both variable sets, we eliminated 12 analytes described previously. Thus the first set of variables consists of the 21 analytes $\mathrm{SiO}_{2}, \mathrm{TiO}_{2}, \mathrm{Al}_{2} \mathrm{O}_{3}, \mathrm{FeO}$, $\mathrm{MnO}, \mathrm{CaO}, \mathrm{Na}_{2} \mathrm{O}, \mathrm{K}_{2} \mathrm{O}, \mathrm{Ba}, \mathrm{Ce}, \mathrm{Co}, \mathrm{Cr}$, $\mathrm{Cs}, \mathrm{Cu}, \mathrm{Ga}, \mathrm{La}, \mathrm{Ni}, \mathrm{Sc}, \mathrm{Sm}, \mathrm{V}$, and $\mathrm{Zn}$. The second set of variables is comprised of the 15 analytes that are common between variable set one and the element set used by Gunter (2003). These include $\mathrm{SiO}_{2}$, $\mathrm{TiO}_{2}, \mathrm{Al}_{2} \mathrm{O}_{3}, \mathrm{FeO} * \mathrm{MnO}, \mathrm{CaO}, \mathrm{K}_{2} \mathrm{O}, \mathrm{Ba}, \mathrm{Cr}, \mathrm{Cu}, \mathrm{Ga}, \mathrm{Ni}, \mathrm{Sc}, \mathrm{V}$, and $\mathrm{Zn}$.

As described in a previous paragraph, there are correlations between several of the analytes. Such correlations can result in ill-conditioning of the variance/covariance matrix which must be inverted during the solution process. We therefore proceeded using a forward stepping scheme to add the most discriminating analyte not currently in the model. The criterion to enter the model was an F statistic $>2$ while the criterion to remove a variable from the model was an F statistic $<1$. Once a variable is added to the model, analytes with correlation coefficients $>0.7$ with the added variable were removed from further consideration. The process was then continued by adding the next most discriminating analyte from the remaining set. This procedure was repeated until an additional analyte resulted in a statistically insignificant $(\mathrm{p}>0.05)$ discriminant coefficient in the model.

\section{Results and Discussion}

\subsection{Data Description}

Analytical results are shown in Table 2. Statistical summaries of the data including means and standard deviations for $\ln$ (concentration) of each analyte by category, box and whisker plots for combined and individual groups, the Pearson correlation coefficient matrix, and categorized probability plots for each element are provided in Appendix A.

shows a spider diagram of all vermiculite samples in this study normalized to primitive mantle (Sun and McDonough, 1989). For illustrative purposes, samples that were below detection limit for a particular element were assigned a value of $0.001 \mathrm{ppm}$ for that element so that it could be plotted on the logarithmic diagram. From Figure 1, it appears that vermiculite from South Carolina is enriched in REE's relative to ores from South Africa and Libby; but its signature substantially overlaps that of ores from China. In contrast, vermiculite from Libby is notably depleted in Th, La, $\mathrm{P}, \mathrm{Sm}$, and Eu compared to ores from the other three localities. South African ores appear to have more geochemical variability than do ores from the other three localities; however they exhibit prominent depletions of $\mathrm{Pb}$ and $\mathrm{Yb}$. 


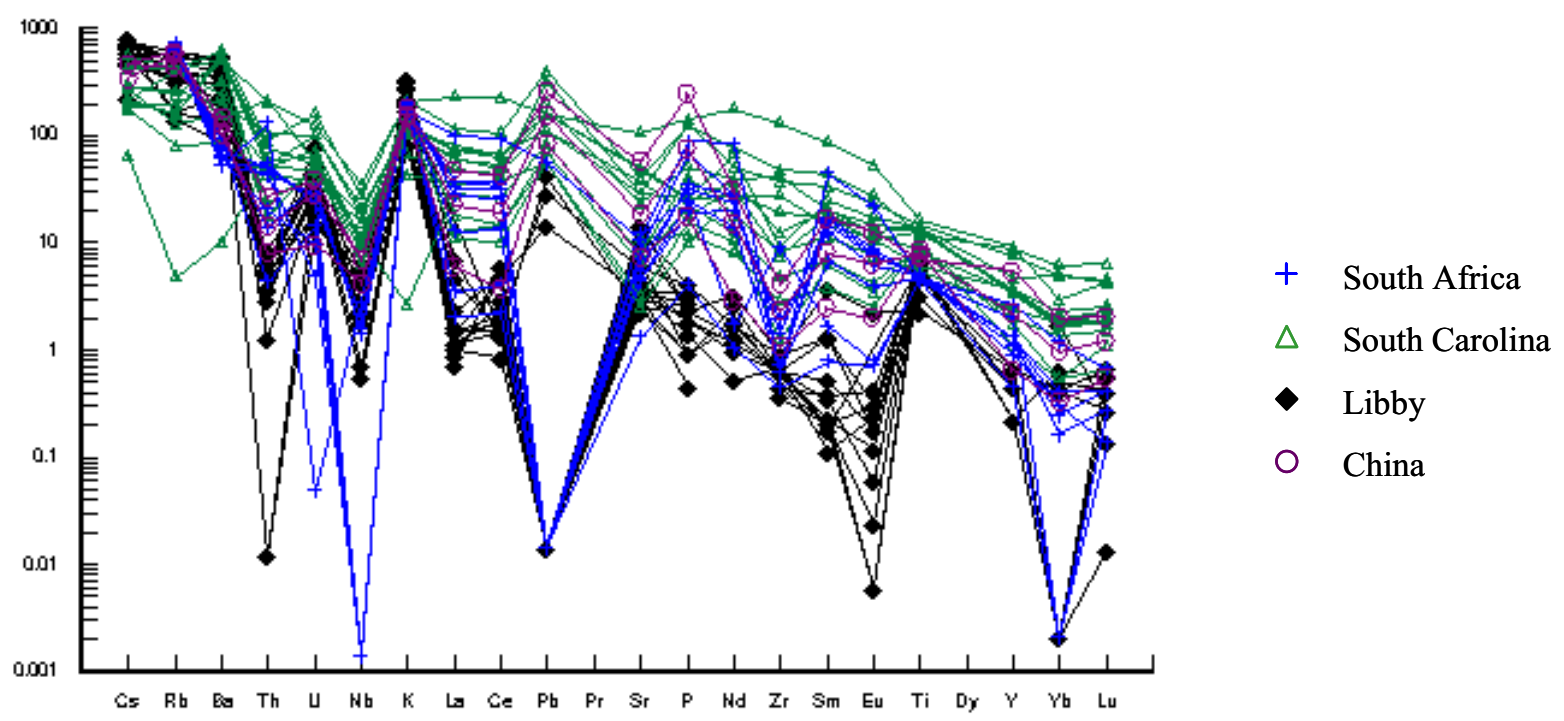

Figure 1. Spider diagram showing all vermiculite samples normalized to primitive mantle (Sun and McDonough, 1989). 
Table 2. Chemical analysis of vermiculite samples. See Table 1 for sample descriptions and locations.

\begin{tabular}{|c|c|c|c|c|c|c|c|c|c|c|c|c|c|c|c|c|}
\hline & GS-1 & GS-3 & GS-13 & GS-17 & GS-18 & PVC1 & PVC2 & PVC3 & GS-7 & GS-12 & GS-16 & GS-11 & GS-15 & $\mathrm{SC2}$ & $\mathrm{SC} 3$ & SC4 \\
\hline $\mathrm{SiO}_{2}$ & 43.0 & 38.3 & 37.8 & 39.1 & 38.9 & 38.7 & 39.4 & 39.2 & 41 & 38.4 & 40.2 & 38.9 & 42.6 & 44.2 & 47.7 & 44.3 \\
\hline $\mathrm{TiO}_{2}$ & 0.85 & 0.88 & 0.86 & 0.91 & 0.9 & 0.845 & 0.906 & 0.952 & 1.41 & 1.53 & 1.48 & 1.62 & 1.8 & 1.04 & 1.66 & 2.69 \\
\hline $\mathrm{Al}_{2} \mathrm{O}_{3}$ & 8.9 & 8.7 & 8.5 & 8.9 & 9.1 & 8.24 & 8.67 & 9.14 & 10.1 & 11.4 & 11.2 & 12.5 & 11.9 & 6.64 & 10.5 & 12.7 \\
\hline $\mathrm{FeO}^{*}$ & 6.11 & 6.74 & 6.74 & 6.65 & 6.38 & 5.92 & 6.42 & 6.94 & 7.1 & 9.35 & 8.72 & 8.27 & 6.92 & 9.26 & 7.60 & 9.26 \\
\hline $\mathrm{MnO}$ & 0.04 & 0.05 & 0.05 & 0.05 & 0.04 & 0.04 & 0.05 & 0.05 & 0.08 & 0.08 & 0.09 & 0.12 & 0.92 & 0.15 & 0.12 & 0.12 \\
\hline MgO & 22.5 & 22.1 & 21.8 & 22.8 & 23 & 23.1 & 23.0 & 23.8 & 12.4 & 16.3 & 16.2 & 17.8 & 17.2 & 22.9 & 14.0 & 11.1 \\
\hline $\mathrm{CaO}$ & 0.6 & 4.0 & 4.5 & 3.1 & 2.5 & 5.16 & 3.79 & 2.30 & 7.8 & 2.5 & 3.8 & 1.2 & 1.8 & 2.65 & 3.93 & 5.16 \\
\hline $\mathrm{Na}_{2} \mathrm{O}$ & $<0.15$ & $<0.15$ & $<0.15$ & $<0.15$ & $<0.15$ & 0.06 & 0.07 & 0.05 & 0.56 & $<0.15$ & 0.17 & $<0.15$ & 0.27 & 0.18 & 0.91 & 1.30 \\
\hline $\mathrm{K}_{2} \mathrm{O}$ & 5.27 & 4.34 & 4.31 & 4.59 & 4.86 & 4.78 & 4.83 & 5.16 & 4.23 & 3.69 & 4.72 & 3.84 & 4.95 & 0.07 & 3.15 & 3.13 \\
\hline $\mathrm{P}_{2} \mathrm{O}_{5}$ & 0.08 & 1.31 & 1.66 & 0.67 & 0.46 & 0.52 & 0.60 & 0.37 & 4.7 & 0.32 & 1.43 & 0.29 & 0.43 & 0.78 & 1.02 & 0.511 \\
\hline LOI (\%) & 10.1 & 11.1 & 11.1 & 10.8 & 10.8 & 8.98 & 8.04 & 7.63 & 8.1 & 13.8 & 10.5 & 13.0 & 8.80 & 8.57 & 6.64 & 6.64 \\
\hline Sum & 98.1 & 98.2 & 98.1 & 98.3 & 97.6 & 96.4 & 95.7 & 95.6 & 98.4 & 98.4 & 98.4 & 98.5 & 97.5 & 96.4 & 97.2 & 96.9 \\
\hline $\mathrm{Ba}$ & 643 & 366 & 359 & 370 & 432 & 644 & 520 & 447 & 1020 & 869 & 725 & 999 & 1640 & 71 & 1360 & 3970 \\
\hline $\mathrm{Ce}^{1}$ & 3.9 & 65.1 & 166 & 55.5 & 23.6 & 7.2 & 60.0 & 46.6 & 76.4 & 6.5 & 34.2 & 26.0 & 25.5 & 45.5 & 113 & 119 \\
\hline $\mathrm{Co}{ }^{1}$ & 75.6 & 62.3 & 71.2 & 67.3 & 67.7 & 80.1 & 58.7 & 62.0 & 51.5 & 66.4 & 60.6 & 72.9 & 59.7 & 73.7 & 48.5 & 35.7 \\
\hline $\mathrm{Cr}^{7}$ & 210 & 251 & 282 & 235 & 215 & 263 & 198 & 238 & 601 & 776 & 1090 & 2150 & 2570 & 229 & 1100 & 442 \\
\hline Cs ${ }^{1}$ & 15.2 & 10.6 & 11.1 & 11.5 & 11.8 & 12.4 & 8.62 & 11.0 & 2.70 & 3.67 & 3.67 & 4.44 & 3.52 & 0.52 & 2.23 & 1.67 \\
\hline $\mathrm{Cu}$ & 7 & 59 & 87 & 41 & 15 & 8 & 17 & 19 & 38 & 31 & 45 & 131 & 73 & 31 & 55 & 20 \\
\hline $\mathrm{Eu}^{1}$ & 0.12 & 1.46 & 3.73 & 1.28 & 0.66 & 0.13 & 1.33 & 1.05 & 2.07 & 0.33 & 1.07 & 0.58 & 0.70 & 1.24 & 2.16 & 2.94 \\
\hline Ga & 16 & 12 & 14 & 14 & 14 & 12 & 12 & 13 & 12 & 8 & 13 & 22 & 18 & 8 & 15 & 16 \\
\hline $\mathrm{Hf}{ }^{1}$ & 0.30 & 0.17 & 0.22 & 0.07 & 0.06 & 0.25 & 0.23 & 0.06 & 0.93 & 0.10 & 0.66 & 0.65 & 1.22 & 5.81 & 11.6 & 2.49 \\
\hline La ' & 1.4 & 25.1 & 66.9 & 22.1 & 8.8 & 2.4 & 25.0 & 19.1 & 31.6 & 4.1 & 15.3 & 12.4 & 8.7 & 19.6 & 50.3 & 54.9 \\
\hline $\mathrm{Lu}{ }^{1}$ & 0.01 & 0.02 & 0.05 & 0.03 & 0.03 & 0.01 & 0.02 & 0.01 & 0.15 & 0.04 & 0.09 & 0.08 & 0.11 & 0.13 & 0.16 & 0.34 \\
\hline $\mathrm{Nd}{ }^{1}$ & 1.4 & 37.7 & 114 & 37.0 & 18.8 & 2.3 & 31.8 & 27.1 & 41.9 & 4.0 & 20.0 & 14.2 & 17.2 & 23.9 & 52.1 & 91.0 \\
\hline Nb & $\mid<2$ & $<2$ & 2 & $<2$ & $<2$ & 1.0 & 1.5 & 1.1 & 5 & 3 & 5 & 7 & 8 & 7.6 & 15 & 7.8 \\
\hline $\mathrm{Ni}$ & 152 & 201 & 223 & 172 & 157 & 148 & 157 & 176 & 458 & 499 & 575 & 331 & 412 & 606 & 535 & 73 \\
\hline $\mathrm{Pb}$ & $<3$ & $<3$ & 4 & $<3$ & $<3$ & $<1$ & $<1$ & $<1$ & 18 & 6 & 11 & 4 & 5 & 6 & 14 & 11 \\
\hline $\mathrm{Rb}$ & 456 & 398 & 386 & 399 & 433 & 411 & 428 & 472 & 364 & 270 & 387 & 271 & 263 & 3 & 168 & 103 \\
\hline $\mathrm{Sc}{ }^{1}$ & 5.0 & 5.2 & 8.7 & 9.4 & 8.8 & 5.9 & 10.6 & 7.5 & 9.3 & 6.6 & 10.7 & 11.8 & 11.3 & 10.6 & 13.0 & 25.1 \\
\hline $\mathrm{Sm}{ }^{1}$ & 0.35 & 7.53 & 19.6 & 6.59 & 2.95 & 0.74 & 7.09 & 5.58 & 7.61 & 1.07 & 3.55 & 2.77 & 3.03 & 4.94 & 9.10 & 11.1 \\
\hline $\mathrm{Sr}$ & 28 & 178 & 225 & 114 & 96 & 257 & 149 & 93 & 1210 & 158 & 384 & 66 & 139 & 171 & 489 & 1050 \\
\hline $\mathrm{Ta}{ }^{1}$ & 0.10 & 0.07 & $<0.02$ & $<0.02$ & 0.04 & 0.33 & 0.43 & 0.40 & 0.03 & 0.01 & 0.04 & 0.04 & 0.66 & 0.32 & 0.74 & 0.35 \\
\hline $\mathrm{Tb}{ }^{1}$ & 0.03 & 0.37 & 1.11 & 0.27 & $<0.05$ & 0.06 & 0.51 & 0.38 & 0.73 & $<0.05$ & 0.32 & $<0.05$ & 0.31 & 0.53 & 0.67 & 0.78 \\
\hline$T{ }^{1}$ & 0.37 & 4.57 & 11.1 & 3.72 & 1.74 & 1.16 & 4.29 & 3.63 & 2.27 & 0.69 & 1.20 & 18.0 & 1.57 & 4.43 & 9.08 & 5.06 \\
\hline$U^{\top}$ & $<0.4$ & 0.5 & $<0.4$ & $<0.4$ & $<0.4$ & 0.7 & 0.5 & 0.6 & 0.8 & $<0.4$ & 0.6 & 1.2 & 1.1 & 1.5 & 2.1 & 1.3 \\
\hline v & 31 & 41 & 35 & 39 & 34 & 13 & 18 & 19 & 161 & 165 & 176 & 194 & 190 & 89 & 124 & 241 \\
\hline $\mathbf{Y}$ & 2 & 9 & 12 & 6 & 5 & 6 & 6 & 4 & 25 & 3 & 10 & 8 & 9 & 11 & 16 & 21 \\
\hline $\mathrm{Yb}{ }^{1}$ & $<0.02$ & $<0.02$ & 0.58 & 0.20 & 0.12 & 0.15 & 0.08 & 0.15 & 0.99 & 0.16 & 0.48 & 0.27 & 0.66 & 0.85 & 0.86 & 2.46 \\
\hline $\mathrm{Zn}$ & 67 & 84 & 81 & 77 & 73 & 61 & 68 & 78 & 109 & 144 & 144 & 138 & 107 & 92 & 94 & 97 \\
\hline $\mathrm{Zr}$ & 5 & 8 & 7 & 8 & 7 & 101 & 16 & 21 & 46 & 12 & 26 & 14 & 53 & 92 & 469 & 101 \\
\hline
\end{tabular}


Table 2. (continued).

\begin{tabular}{|c|c|c|c|c|c|c|c|c|c|c|c|c|c|c|c|c|}
\hline & |sc5 & Sc6 & SC7 & SC8 & Sc9 & SC10 & SC11 & PVC5 & GS-2 & GS-4 & GS-10 & $1 \mathrm{~A}$ & $2 A$ & $3 A$ & $4 \mathrm{~A}$ & $5 \mathrm{~A}$ \\
\hline $\mathrm{SiO}_{2}$ & 41.8 & 44.3 & 42.9 & 49.7 & 43.8 & 44.1 & 39.2 & 40.0 & 37.8 & 37.4 & 36.9 & 49.9 & 37.5 & 39.3 & 39.8 & 38.4 \\
\hline $\mathrm{TiO}_{2}$ & 3.30 & 2.65 & 2.38 & 1.23 & 2.31 & 2.73 & 2.92 & 1.90 & 1.09 & 1.24 & 1.22 & 0.48 & 1.23 & 1.15 & 1.09 & 1.47 \\
\hline $\mathrm{Al}_{2} \mathrm{O}_{3}$ & 11.6 & 12.4 & 11.4 & 9.9 & 15.1 & 11.5 & 9.88 & 12.4 & 11.6 & 12.0 & 12.1 & 3.71 & 12.5 & 13.1 & 9.54 & 13.7 \\
\hline $\mathrm{FeO}^{*}$ & 10.1 & 9.16 & 11.0 & 8.24 & 9.88 & 8.90 & 16.8 & 8.39 & 8.45 & 8.9 & 8.63 & 4.59 & 9.56 & 8.00 & 7.67 & 8.87 \\
\hline MnO & 0.12 & 0.13 & 0.15 & 0.15 & 0.24 & 0.12 & 0.19 & 0.09 & 0.09 & 0.10 & 0.08 & 0.08 & 0.10 & 0.08 & 0.08 & 0.08 \\
\hline $\mathrm{MgO}$ & 8.66 & 11.5 & 16.5 & 13.1 & 6.35 & 13.2 & 8.59 & 17.2 & 19.5 & 19.7 & 20.3 & 17.8 & 21.3 & 22.2 & 19.3 & 22.2 \\
\hline $\mathrm{CaO}$ & 7.48 & 5.28 & 1.76 & 6.13 & 3.60 & 6.49 & 8.91 & 1.94 & 2.10 & 1.70 & 1.30 & 18.7 & 1.02 & 0.38 & 7.48 & 0.29 \\
\hline $\mathrm{Na}_{2} \mathrm{O}$ & 0.65 & 1.25 & 0.11 & 1.28 & 0.26 & 1.28 & 0.91 & 0.41 & $<0.15$ & 0.19 & 0.16 & 0.38 & 0.20 & 0.22 & 0.14 & 0.25 \\
\hline $\mathrm{K}_{2} \mathrm{O}$ & 5.79 & 3.00 & 1.13 & 1.86 & 5.80 & 2.88 & 3.71 & 3.80 & 5.03 & 6.00 & 5.07 & 2.29 & 7.60 & 9.56 & 2.78 & 9.56 \\
\hline $\mathrm{P}_{2} \mathrm{O}_{5}$ & 2.87 & 0.50 & 0.19 & 0.51 & 2.45 & 0.36 & 2.59 & 0.23 & 0.06 & $<0.05$ & $<0.05$ & 0.04 & 0.03 & 0.02 & 0.02 & 0.02 \\
\hline LOI (\%) & 3.83 & 6.86 & 9.40 & 5.31 & 6.28 & 5.29 & 2.74 & 9.22 & 11.1 & 9.00 & 11.0 & 0.90 & 3.89 & 0.79 & 8.85 & 1.01 \\
\hline Sum & 96.2 & 97.0 & 97.1 & 97.4 & 96.1 & 96.8 & 96.5 & 95.7 & 97.7 & 97.2 & 97.7 & 98.8 & 94.9 & 94.8 & 96.8 & 95.8 \\
\hline Ba & 3720 & 3910 & 599 & 1090 & 4280 & 3710 & 2290 & 3580 & 2550 & 2510 & 2120 & 603 & 3300 & 2860 & 1620 & 3430 \\
\hline $\mathrm{Ce}{ }^{1}$ & 404 & 93.6 & 66.8 & 76.7 & 187 & 86.3 & 122 & 17.8 & 10.6 & 8.8 & 2.7 & 8.8 & 8.2 & 3.9 & 1.5 & 2.3 \\
\hline $\mathrm{Co}{ }^{1}$ & 36.8 & 38.9 & 58.5 & 48.7 & 59.2 & 38.6 & 50.0 & 51.6 & 63.4 & 63.3 & 67.2 & 33.1 & 67.1 & 55.1 & 81.6 & 76.1 \\
\hline $\mathrm{Cr}^{1}$ & 285 & 480 & 865 & 1290 & 102 & 512 & 12.3 & 1220 & 1950 & 1550 & 1250 & 1150 & 2210 & 1410 & 1180 & 825 \\
\hline$C s^{1}$ & 1.73 & 1.62 & 1.37 & 2.11 & 3.30 & 1.71 & 1.44 & 2.38 & 5.69 & 5.57 & 4.71 & 1.80 & 5.68 & 4.17 & 5.18 & 5.90 \\
\hline $\mathrm{Cu}$ & 18 & 18 & 120 & 28 & 112 & 20 & 41 & 66 & 30 & 26 & 13 & 3 & 4 & 1 & 3 & 2 \\
\hline $\mathrm{Eu}{ }^{1}$ & 8.89 & 2.42 & 1.85 & 1.77 & 4.64 & 2.17 & 3.85 & 0.42 & 0.05 & 0.07 & 0.05 & 0.38 & $<0.01$ & 0.03 & $<0.01$ & 0.04 \\
\hline Ga & 19 & 17 & 16 & 13 & 21 & 15 & 18 & 16 & 16 & 18 & 18 & 6 & 16 & 16 & 13 & 16 \\
\hline$H f^{1}$ & 34.7 & 3.46 & 4.96 & 5.93 & 13.1 & 1.89 & 10.4 & 0.55 & 0.09 & 0.22 & 0.05 & 0.08 & 0.30 & 0.27 & 0.18 & 0.37 \\
\hline $\mathrm{La}^{\prime}$ & 157 & 41.8 & 24.7 & 33.9 & 78.2 & 42.8 & 49.3 & 7.6 & 0.5 & 0.6 & 0.0 & 1.6 & 1.0 & 1.0 & 0.7 & 4.7 \\
\hline $\mathrm{Lu}{ }^{1}$ & 0.31 & 0.14 & 0.17 & 0.19 & 0.47 & 0.13 & 0.32 & 0.05 & 0.02 & 0.03 & 0.02 & 0.05 & 0.02 & 0.04 & 0.03 & 0.02 \\
\hline $\mathrm{Nd}^{1}$ & 243 & 49.4 & 38.7 & 36.9 & 103 & 42.3 & 68.8 & 10.9 & $<0.5$ & $<0.5$ & $<0.5$ & 4.4 & 0.7 & 2.4 & 3.5 & $<0.5$ \\
\hline $\mathrm{Nb}$ & 25 & 7.0 & 11 & 13 & 20 & 5.8 & 13 & 4.4 & 4.0 & 4.0 & 3.0 & 1.3 & 2.0 & 1.3 & 1.7 & 1.3 \\
\hline $\mathrm{Ni}$ & 243 & 74 & 360 & 277 & 51 & 68 & 11 & 440 & 211 & 232 & 206 & 112 & 186 & 264 & 129 & 221 \\
\hline $\mathrm{Pb}$ & 11 & 11 & 4 & 23 & 28 & 8 & 8 & 4 & $<3$ & $<3$ & 3 & $<1$ & $<1$ & $<1$ & $<1$ & $<1$ \\
\hline $\mathbf{R b}$ & 256 & 103 & 51 & 81 & 276 & 99 & 124 & 152 & 238 & 236 & 200 & 90 & 297 & 378 & 106 & 387 \\
\hline $\mathrm{Sc}{ }^{1}$ & 24.1 & 25.2 & 14.5 & 18.3 & 27.6 & 26.3 & 41.6 & 10.7 & 9.8 & 14.0 & 12.9 & 74.2 & 16.9 & 38.0 & 11.9 & 17.6 \\
\hline $\mathrm{Sm}^{1}$ & 38.8 & 8.83 & 7.50 & 6.67 & 19.7 & 8.04 & 14.6 & 1.69 & 0.09 & 0.17 & 0.09 & 1.63 & 0.08 & 0.57 & 0.08 & 0.05 \\
\hline $\mathrm{Sr}$ & 2260 & 1010 & 53 & 601 & 852 & 794 & 608 & 233 & 75 & 71 & 48 & 303 & 74 & 51 & 133 & 60 \\
\hline $\mathrm{Ta}{ }^{1}$ & 1.40 & 0.36 & 0.62 & 0.62 & 1.40 & 0.31 & 0.55 & 0.60 & 0.17 & 0.16 & 0.03 & 0.82 & 0.51 & 0.45 & 0.16 & 0.42 \\
\hline $\mathrm{Tb}{ }^{7}$ & 1.96 & 0.80 & 0.62 & 0.28 & 1.47 & 0.69 & 1.23 & 0.24 & 0.05 & 0.03 & $<0.05$ & $<0.05$ & 0.1 & $<0.05$ & $<0.05$ & $<0.05$ \\
\hline $\mathrm{Th}{ }^{7}$ & 17.1 & 6.49 & 3.69 & 4.61 & 7.55 & 4.24 & 1.98 & 1.47 & $<0.02$ & $<0.02$ & 0.11 & 0.71 & 0.52 & 0.25 & 0.43 & 0.30 \\
\hline $\mathbf{U}^{\top}$ & 2.6 & 1.1 & 0.8 & 2.1 & 3.4 & 1.0 & 1.0 & 1.1 & 0.6 & $<0.4$ & 0.5 & 1.0 & 1.7 & 0.8 & 0.6 & 0.6 \\
\hline v & 302 & 239 & 141 & 133 & 230 & 261 & 480 & 182 & 122 & 134 & 123 & 51 & 96 & 85 & 72 & 94 \\
\hline $\mathbf{Y}$ & 41 & 17 & 16 & 17 & 39 & 15 & 35 & 5 & $<2$ & $<2$ & $<2$ & 3 & $<1$ & 1 & 2 & $<1$ \\
\hline$Y_{b^{\prime}}$ & 1.44 & 0.90 & 0.98 & 1.11 & 3.04 & 0.82 & 2.44 & 0.27 & 0.20 & 0.25 & $<0.02$ & 0.20 & 0.86 & 0.32 & $<0.02$ & $<0.02$ \\
\hline $\mathrm{Zn}$ & 140 & 97 & 193 & 103 & 151 & 84 & 139 & 103 & 65 & 76 & 67 & 23 & 69 & 51 & 42 & 53 \\
\hline $\mathrm{Zr}$ & 1456 & 139 & 217 & 310 & 539 & 84 & 411 & 32 & 5.0 & 5.0 & 4 & 10 & 8 & 7 & 7 & 7 \\
\hline
\end{tabular}


Table 2. (continued).

\begin{tabular}{|c|c|c|c|c|c|c|c|c|c|c|c|c|}
\hline & $6 A$ & $7 \mathrm{~A}$ & $8 \mathrm{~A}$ & $9 \mathrm{~A}$ & $10 \mathrm{~A}$ & $11 \mathrm{~A}$ & P1 & P2 & P3 & P4 & P5 & P6 \\
\hline $\mathrm{SiO}_{2}$ & 37.5 & 38.3 & 36.3 & 42.2 & 48.3 & 37.7 & 39.1 & 38.8 & 39.6 & 38.4 & 38.8 & 38.1 \\
\hline $\mathrm{TiO}_{2}$ & 1.42 & 1.28 & 1.28 & 0.90 & 0.66 & 1.22 & 1.39 & 0.77 & 2.24 & 1.26 & 1.28 & 1.21 \\
\hline $\mathrm{Al}_{2} \mathrm{O}_{3}$ & 13.2 & 12.8 & 12.1 & 8.0 & 4.9 & 12.1 & 13.4 & 6.8 & 13.3 & 11.9 & 12.8 & 12.1 \\
\hline $\mathrm{FeO}^{*}$ & 10.9 & 8.7 & 10.6 & 6.96 & 6.07 & 9.08 & 9.15 & 5.77 & 9.72 & 9.24 & 8.80 & 5.06 \\
\hline MnO & 0.09 & 0.08 & 0.11 & 0.09 & 0.09 & 0.09 & 0.10 & 0.05 & 0.12 & 0.09 & 0.10 & 0.04 \\
\hline $\mathrm{MgO}$ & 21.3 & 21.4 & 19.6 & 18.4 & 17.6 & 19.8 & 21.9 & 19.7 & 19.1 & 19.4 & 21.7 & 23.2 \\
\hline $\mathrm{CaO}$ & 0.11 & 1.15 & 1.75 & 10.6 & 16.9 & 2.11 & 1.51 & 10.1 & 1.40 & 2.93 & 1.14 & 1.98 \\
\hline $\mathrm{Na}_{2} \mathrm{O}$ & 0.25 & 0.22 & 0.16 & 0.23 & 0.30 & 0.28 & 0.14 & 0.10 & 0.09 & 0.28 & 0.22 & 1.45 \\
\hline $\mathrm{K}_{2} \mathrm{O}$ & 9.02 & 8.03 & 5.63 & 2.94 & 2.40 & 4.58 & 5.57 & 4.06 & 4.05 & 4.62 & 6.29 & 4.38 \\
\hline $\mathrm{P}_{2} \mathrm{O}_{5}$ & 0.01 & 0.04 & 0.08 & 0.04 & 0.09 & 0.03 & 0.04 & 2.49 & 0.47 & 0.04 & 0.01 & 0.07 \\
\hline LOI (\%) & 1.59 & 3.05 & 7.23 & 6.16 & 1.64 & 9.24 & 4.19 & 7.26 & 6.34 & 7.96 & 4.27 & 7.89 \\
\hline Sum & 95.5 & 95.0 & 95.0 & 96.5 & 99.0 & 96.3 & 96.5 & 95.9 & 96.4 & 96.2 & 95.5 & 95.5 \\
\hline $\mathrm{Ba}$ & 3760 & 2670 & 3870 & 1450 & 1020 & 2140 & 2520 & 464 & 1210 & 2300 & 2440 & 2560 \\
\hline $\mathrm{Ce}{ }^{1}$ & 5.1 & 3.1 & 3.4 & 2.6 & 2.5 & 2.6 & 9.9 & 354 & 51.3 & 7.0 & 11.1 & 14.1 \\
\hline $\mathrm{Co}{ }^{1}$ & 78.6 & 77.5 & 81.8 & 69.6 & 66.2 & 71.3 & 84.9 & 48.9 & 66.0 & 79.3 & 81.7 & 65.3 \\
\hline $\mathrm{Cr}{ }^{1}$ & 1840 & 1190 & 1280 & 1210 & 276 & 1000 & 1540 & 315 & 1140 & 821 & 1650 & 2220 \\
\hline Cs ${ }^{1}$ & 5.73 & 6.28 & 4.61 & 3.54 & 4.66 & 3.89 & 6.62 & 8.98 & 4.32 & 5.14 & 6.76 & 3.86 \\
\hline $\mathrm{Cu}$ & 2 & 4 & 27 & 4 & 2 & 13 & 17 & 23 & 102 & 17 & 25 & 6 \\
\hline $\mathrm{Eu}{ }^{\prime}$ & $<0.01$ & 0.01 & $<0.01$ & 0.03 & 0.05 & 0.02 & 0.04 & 7.72 & 1.87 & 0.01 & $<0.01$ & 0.20 \\
\hline Ga & 17 & 15 & 16 & 10 & 5.8 & 16 & 17 & 10 & 23 & 16 & 18 & 14 \\
\hline $\mathrm{Hf}{ }^{\prime}$ & 0.24 & 0.49 & 0.48 & 0.24 & 0.69 & 0.26 & 0.35 & 0.56 & 3.17 & 0.26 & 0.30 & 0.58 \\
\hline La $^{\prime}$ & 0.7 & 1.0 & 0.8 & 1.1 & 0.8 & 3.1 & 0.3 & 145 & 19.5 & 0.7 & 0.3 & 3.2 \\
\hline Lu ' & 0.02 & 0.02 & 0.01 & $<0.01$ & 0.05 & 0.02 & 0.02 & 0.09 & 0.22 & 0.02 & 0.02 & 0.01 \\
\hline $\mathrm{Nd}^{7}$ & $<0.5$ & 1.6 & 2.3 & 1.8 & 2.3 & 1.3 & 1.6 & 187 & 28.6 & 0.2 & $<0.5$ & 4.3 \\
\hline $\mathrm{Nb}$ & 1.5 & 1.3 & 1.6 & 0.5 & 0.4 & 1.4 & 3.0 & 1.5 & 9.2 & 2.0 & 2.7 & 3.0 \\
\hline $\mathrm{Ni}$ & 143 & 240 & 154 & 146 & 81 & 180 & 235 & 129 & 493 & 166 & 233 & 382 \\
\hline $\mathrm{Pb}$ & $<1$ & $<1$ & 2 & $<1$ & $<1$ & $<1$ & 1 & 2 & 2 & 8 & 3 & $<1$ \\
\hline $\mathbf{R b}$ & 337 & 309 & 364 & 226 & 103 & 202 & 257 & 365 & 282 & 203 & 276 & 241 \\
\hline$S c^{1}$ & 16.2 & 15.4 & 11.7 & 16.1 & 34.6 & 14.5 & 13.4 & 17.7 & 15.5 & 14.2 & 12.7 & 10.0 \\
\hline $\mathrm{Sm}^{1}$ & 0.10 & 0.15 & 0.09 & 0.23 & 0.58 & 0.10 & 0.10 & 41.9 & 7.34 & 0.13 & 0.06 & 0.83 \\
\hline $\mathrm{Sr}$ & 55 & 72 & 125 & 215 & 269 & 91 & 52 & 430 & 92 & 91 & 61 & 206 \\
\hline $\mathrm{Ta}^{7}$ & 0.22 & 0.23 & 0.34 & 0.21 & 0.41 & 0.17 & 0.54 & 0.67 & 0.84 & 0.41 & 0.52 & 0.50 \\
\hline $\mathrm{Tb}^{7}$ & $<0.05$ & $<0.05$ & $<0.05$ & $<0.05$ & $<0.05$ & $<0.05$ & 0.07 & 2.56 & 0.84 & $<0.05$ & 0.17 & 0.15 \\
\hline $\mathrm{Th}{ }^{7}$ & 0.46 & 0.52 & 0.55 & 0.49 & 0.31 & 0.43 & 0.73 & 20.8 & 2.55 & 0.40 & 0.64 & 1.10 \\
\hline $\mathbf{U}^{\top}$ & 0.9 & 0.5 & 1.0 & 0.8 & 0.6 & 0.4 & 0.6 & 1.1 & 1.6 & 0.7 & 0.6 & 0.9 \\
\hline v & 103 & 93 & 89 & 69 & 64 & 86 & 95 & 18 & 172 & 94 & 103 & 55 \\
\hline $\mathbf{Y}$ & $\mid<1$ & $<1$ & $<1$ & 2.8 & 2.2 & $<1$ & 1.1 & 23 & 21 & $<1$ & $<1$ & 1.7 \\
\hline $\mathrm{Yb}{ }^{7}$ & $<0.02$ & $<0.02$ & $<0.02$ & $<0.02$ & $<0.02$ & $<0.02$ & 0.22 & 0.74 & 1.44 & 0.25 & 0.27 & 0.24 \\
\hline Zn & 58 & 51 & 75 & 40 & 30 & 108 & 70 & 60 & 171 & 63 & 79 & 38 \\
\hline $\mathrm{Zr}$ & 7 & 7 & 7 & 7 & 10 & 7 & 7 & 22 & 46 & 8 & 6 & 12 \\
\hline
\end{tabular}


A Pearson correlation matrix is provided in Appendix A. Elements with correlation coefficients exceeding 0.7 are shown in Table 3. Lanthanum was chosen for use in cluster analysis because its presence is associated with monazite, a mineral known to be present in South Carolina but not at Libby. While Ce and Sm are also associated with monazite, La is easily measured with XRF, a common laboratory instrument. Vanadium was chosen for use in statistical analyses over Ti and Mn. Manganese is in low concentration in vermiculite and may be difficult to detect in some samples. Titanium can substitute into the lattices of both biotite and clinopyroxene whereas $\mathrm{V}$ is more specific to substitution in clinopyroxene (Deer et al., 1992). Therefore the abundance of clinopyroxene or its trace element composition may be diagnostic of provenance. Cesium was chosen over sodium because sodium is in low concentration in vermiculite samples and may be difficult to detect in some samples.

Table 3. Table of highly correlated elements. Elements in bold were used in cluster analysis while the other correlated elements were removed from the analysis.

\begin{tabular}{|ccc|}
\hline Element & Correlated Element & Correlation Coefficient \\
\hline \hline La & $\mathrm{Ce}$ & 0.887 \\
& $\mathrm{Sm}$ & 0.927 \\
& & 0.809 \\
\hline $\mathbf{V}$ & $\mathrm{Ti}$ & 0.711 \\
& $\mathrm{Mn}$ & \\
\hline $\mathbf{C s}$ & $\mathrm{Na}$ & 0.701 \\
\hline
\end{tabular}

The statistical methods that we employ have an underlying assumption of the data being normally distributed; therefore, it is worth reviewing this assumption with the data set employed in this study. Normality can be determined using statistical tests such at the Shapiro-Wilk (preferred) or KolmorgorovSmirnov test and viewed graphically using probability plots (Appendix A) which should be linear for normal distributions. Although normality is required for the mathematical development of many statistical tests, the severity of the impact of using those tests when there is a violation of normality is not necessarily great (StatSoft, 2007). For the South African samples, every variable fits a normal distribution ( $\mathrm{p}>0.05)$ using the Shapiro-Wilk test except for $\mathrm{SiO}_{2}$ and $\mathrm{CaO}$. Both of these exceptions can be explained by an outlier (the same sample) with the remaining data fitting a normal distribution. All of the China samples fit a normal distribution except for $\mathrm{SiO}_{2}, \mathrm{Cs}$, and $\mathrm{CaO}$. The latter two results are explained by duplicate results with only three samples in the category. For $\mathrm{SiO}_{2}$ in the China category, the data approximates a straight line and it fits a normal curve according to the Kolmorgorov-Smirnov test. For the South Carolina samples, $\mathrm{MnO}, \mathrm{K}_{2} \mathrm{O}, \mathrm{Ba}, \mathrm{Ni}$, and $\mathrm{Rb}$ failed the Shapiro-Wilk test. For all of the elements that failed the test, the probability plots appear to be comprised of two straight-line segments implying that the South Carolina samples are comprised of at least two subcategories that are normally distributed. However, the samples comprising the straight line segments are not consistent between analytes.

For the Libby category, $\mathrm{TiO}_{2}, \mathrm{Al}_{2} \mathrm{O}_{3}, \mathrm{FeO}, \mathrm{MgO}, \mathrm{Co}, \mathrm{Cr}, \mathrm{Cs}, \mathrm{Ga}, \mathrm{La}, \mathrm{Rb}, \mathrm{Sc}$, and $\mathrm{Sm}$ failed the normality test. The results for $\mathrm{Co}, \mathrm{Cr}, \mathrm{Cs}$, and $\mathrm{La}$ can be explained by a single outlier and are assumed to be normally distributed. For $\mathrm{Rb}$, the deviations from a straight line are small and it does pass the Kolmorgorov-Smirnov test. For the remaining elements that failed the test $\left(\mathrm{TiO}_{2}, \mathrm{Al}_{2} \mathrm{O}_{3}, \mathrm{FeO}, \mathrm{MgO}, \mathrm{Ga}\right.$, $\mathrm{Sc}$, and $\mathrm{Sm}$ ) the probability plots appear to be comprised of two line segments. Samples 1A, 4A, 9A, and 10A appear together in one of the line segments in a majority of those analytes. This is consistent with the origin of Libby from fractional crystallization from a single parent magma (Boettcher, 1966). Such paragenesis can be indicated by the non-normal distribution of trace elements (Kawabe, 1977). 


\subsection{Hierarchial Cluster Analysis}

Cluster analysis is used to determine if there are characteristics of samples that allow them to be separated into different groups. Clustering methods can be applied when there is limited prior knowledge about the samples being analyzed. The results of hierarchial methods can be displayed as graphical output in the form of a dendrogram or tree that illustrates the distance between each of the clusters. There are several different agglomerative hierarchial cluster analysis methods based on the choice of linkage (amalgamation) method and the choice of measure of similarity (distance) between the clusters (e.g., Rencher, 2002). These hierarchial clustering techniques are non-unique in the sense that different clusters can be obtained depending on the choice of method. We chose to use four different linkage methods: single, complete, unweighted average, and Ward's methods. All of these methods are known to be monotonic, i.e., not show inversions (reversals) in the dendrogram (e.g., Morgan and Ray, 1995; Rencher, 2002). Single linkage defines the distance between two clusters as the minimum distance between a point $\mathrm{A}$ in one cluster and a point $\mathrm{B}$ in the other cluster. In contrast, complete linkage defines the distance between two clusters as the maximum distance between point $\mathrm{A}$ and point $\mathrm{B}$. The average linkage approach defines the distance between two clusters $\mathrm{A}$ and $\mathrm{B}$ as the average of $n_{\mathrm{a}} n_{\mathrm{b}}$ distances between the $n_{\mathrm{a}}$ points in A and the $n_{\mathrm{b}}$ points in B. Ward's method uses within-cluster and between-cluster distances to join clusters in a way that minimizes within-cluster distances (Rencher, 2002; Systat, 2007). In general, Ward's method and average linkage method are often preferred because they are relatively insensitive to outliers, although some types of data sets simply work better with some linkage methods than with others (Rencher, 2002).

In addition to the selected linkage method, it was necessary to choose a method to determine clustering distances. Clustering distance algorithms are specific to the type of data being analyzed. For example, some distance methods are appropriate for counts of objects while other methods are specific for quantitative data. Still other methods are more suitable for data that has been standardized. Absolute distance measure is appropriate for standardized, quantitative data (Systat, 2007) and it was used in our cluster analysis. Following the rationale outlined previously, the 15 elements used in the cluster analysis are: $\mathrm{SiO}_{2}, \mathrm{Al}_{2} \mathrm{O}_{3}, \mathrm{FeO}^{*}, \mathrm{CaO}, \mathrm{K}_{2} \mathrm{O}, \mathrm{Ba}, \mathrm{Co}, \mathrm{Cr}, \mathrm{Cs}, \mathrm{Cu}, \mathrm{La}, \mathrm{Ni}, \mathrm{Sc}, \mathrm{V}$ and $\mathrm{Zn}$.

Figure 2 (A-D) shows the cluster trees containing all the ore and product samples used in this study using single, complete, and unweighted average linkages and Ward's method, respectively. All of the dendrograms were computed with Euclidian distances. To determine the number of clusters from the dendrogram, we chose the number of clusters at the stage where

$$
d_{j}>\bar{d}+k s_{d} \quad j=1,2, \ldots n
$$

for the first time, where $\mathrm{d}_{1}, \mathrm{~d}_{2}, \ldots \mathrm{d}_{\mathrm{n}}$ are the distances when there are $\mathrm{n}, \mathrm{n}-1, \mathrm{n}-2, . ., 1$ clusters and $\overline{\boldsymbol{d}}$ and $\mathrm{s}_{\mathrm{d}}$ are the mean and standard deviation of the d (e.g., Rencher, 2002; Mojena, 1977). We used the recommended (Milligan and Cooper, 1985) value of 1.25 for the $\mathrm{k}$ parameter.

The samples in the single linkage method (Figure 2A) tend to remain separated (chaining), consistent with results that others have obtained using this linkage method (Rencher, 2002). Using the linkage distance cutoff from Eq. (1) there appear to be two orphans (SC2, SC11) and two groups (SA+P2, everything else). This method suggests only minimal clustering occurs and that it would be difficult to identify sources of vermiculite. In contrast, the complete linkage approach (Figure 2B) forms more clusters (7) with only 1 orphan (SC2). The clusters include 1) a subset of the SC samples; 2) a subset of SC samples, 
CH samples, plus P3; 3) a subset of SA samples plus P2; 4) a group comprised of two SA samples (SA GS-1, SA PVC-1); 5) a subset of the L samples plus P1, P4, and P5; 6) a second subset of L samples plus P6; and 7) a third subset of L samples. The existence of subcategories for the $\mathrm{L}$ and $\mathrm{SC}$ categories is consistent with the observations of the probability plots discussed in previous paragraphs.

The unweighted average linkage (Figure 2C) and Ward's method (Figure 2D) generated 3 and 4 groups, respectively. The clusters in the unweighted average method were comprised of the L category plus $\mathrm{P} 1$, P2, P4, and P6; the SA category plus P5; and a subset of the SC category plus the CH category and P3. There were two orphans (SC2 and SC11). The four clusters generated in Ward's method were L with P1, P4, P5, and P6; SA with P2; a subset of SC; and another subset of SC with the CH samples and P3.

Except for the single linkage method, which only distinguishes SA samples, the cluster analyses used show that Libby and South Africa ores are distinct from each other and distinct from South Carolina and China ores, but that China ores and South Carolina ores cannot be distinguished from one another. Only Ward's method did not have any orphans. The particular samples that plot as orphans vary with the linkage method chosen. None of the methods distinguishes samples from China. While the general grouping of the six products is the same in all cluster trees, several of the known samples plot as orphans. Cluster analysis suggests that P1, P4, P5, and P6 are Libby products, whereas P2 is likely from South Africa and P3 is likely from South Carolina. 
Single Linkage

Euclidean distances

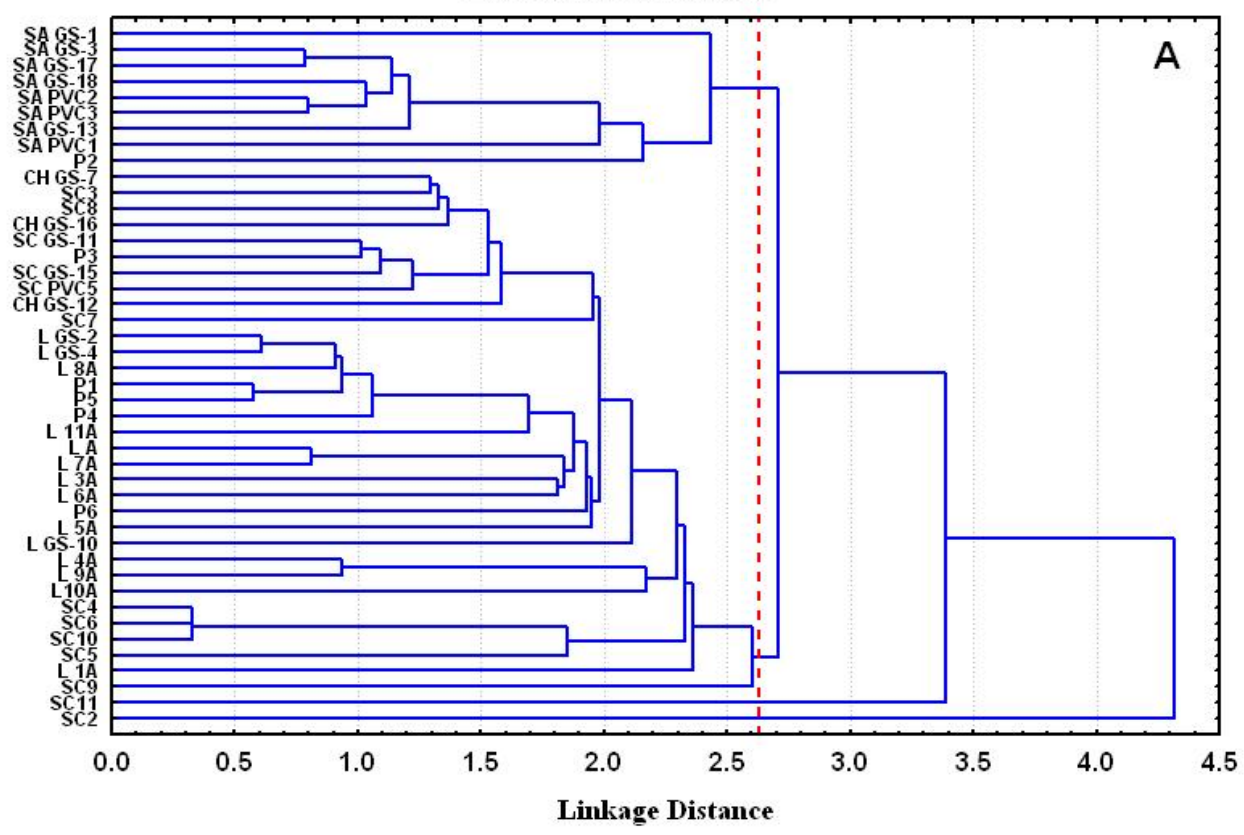

Complete Linkage

Euclidean distances

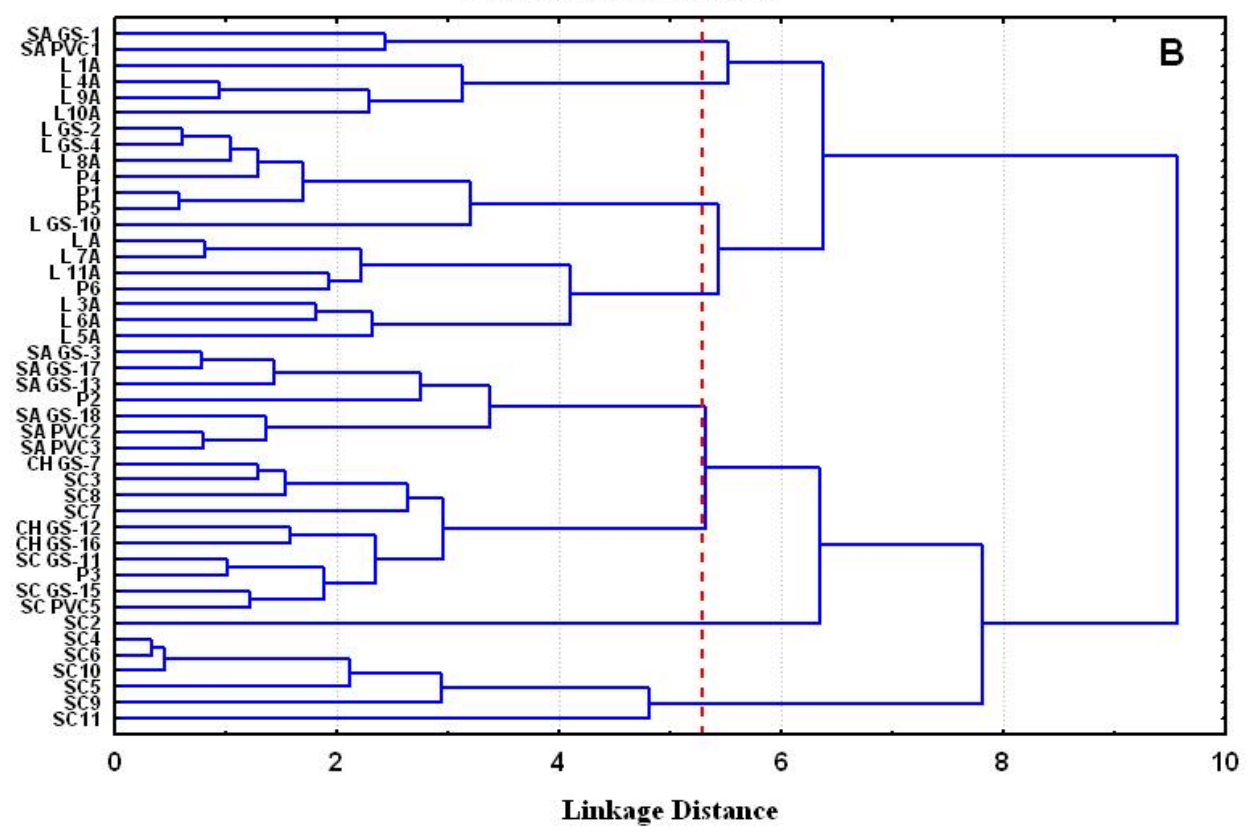


Unweighted pair-group average

Euclidean distances

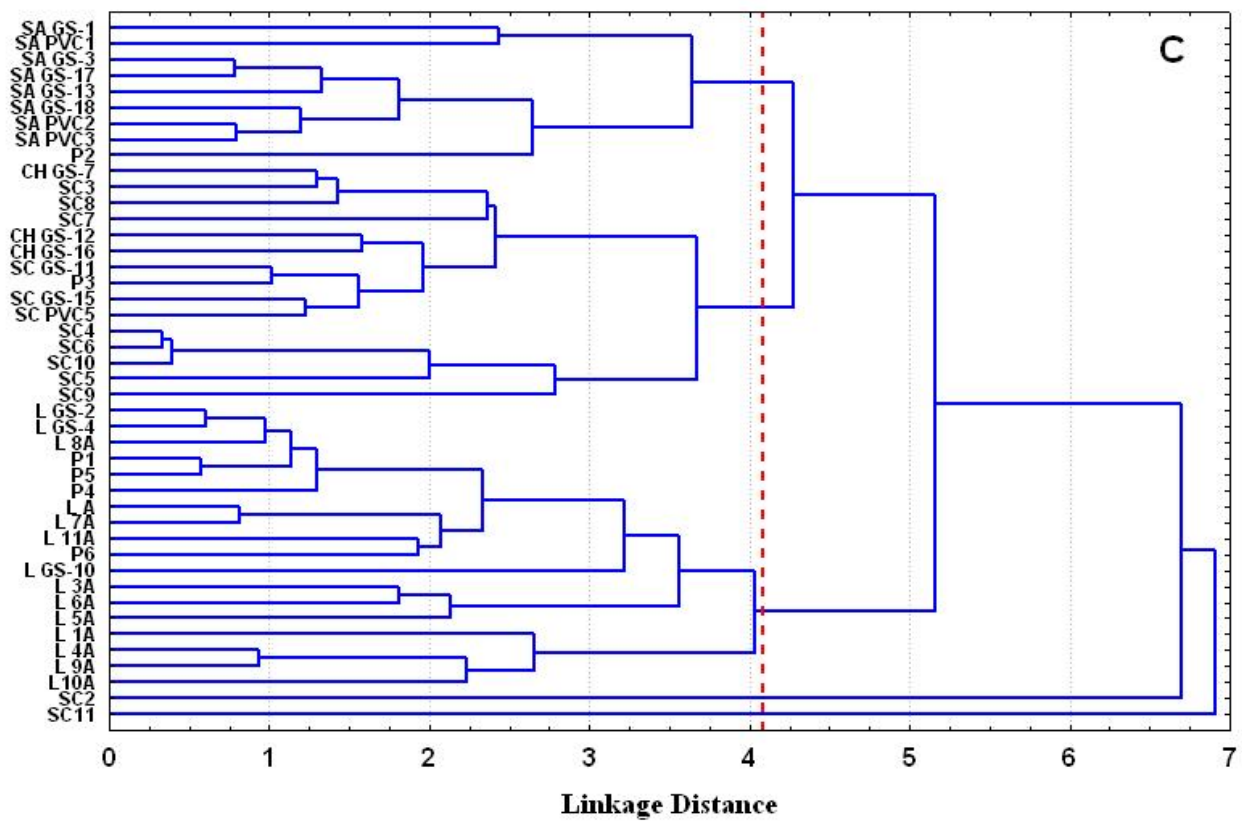

Ward's method

Euclidean distances

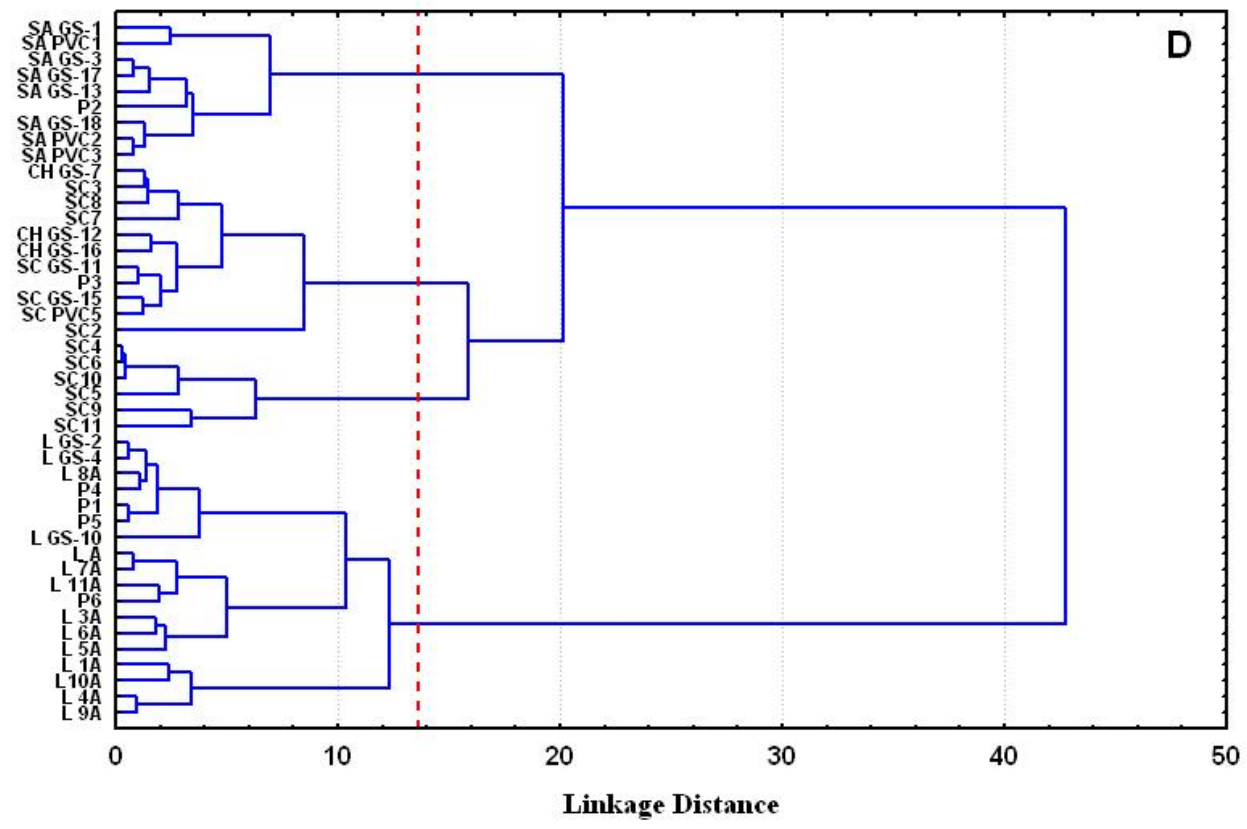

Figure 2. Cluster diagrams using single linkage (A), complete linkage (B), unweighted pair-group average (C), and Ward's method (D). All of the methods used Euclidean distances. All ores and products analyzed in this study are shown. Samples of known origin have their sample names preceded by a location designation ( $\mathrm{SC}=$ South Carolina, $\mathrm{SA}=$ South Africa, $\mathrm{CH}=$ China, $\mathrm{L}=$ Libby, $\mathrm{P}=$ product), although a priori knowledge of the sample origin has no effect on the cluster analysis. 


\subsection{K-Cluster Analysis}

We applied k-cluster analysis to test whether allowing the individual samples to be reclassified as the centroids of the clusters as identified would make a large difference in the perceived clusters. We considered 4, 5, 6, and 7 clusters with seeds chosen from the dendrogram for Ward's methods (Figure 2d, Table 4). The results yield clusters similar to those obtained from the hierachial analysis with the exception that sample SA GS-1 was assigned to one of the Libby subcategories rather than to the South African categories. To determine which of the four scenarios bests represents the clustering, we calculated

$$
c=\frac{\operatorname{tr}(\mathbf{H}) /(k-1)}{\operatorname{tr}(\mathbf{E}) /(n-k)}
$$

where $\operatorname{tr}(\mathbf{H})$ and $\operatorname{tr}(\mathbf{E})$ are the traces (sum of the diagonal elements) of the $\mathrm{p} \mathrm{x} \mathrm{p} \mathrm{between} \mathrm{group} \mathrm{and} \mathrm{within}$ group sum of product matrices, $\mathrm{p}$ is the number of variables (15), $\mathrm{n}$ is the total number of samples (44) and $\mathrm{k}$ is the number of clusters (Rencher, 2002). The ranks of $\mathbf{E}$ and $\mathbf{H}$ are $\mathrm{p}$ and $\mathrm{k}-1$, respectively. The number of clusters that maximizes $\mathrm{c}$ is likely to be the best model. For the scenarios tested, the maximum c occurs with 5 clusters (Figure 3 ). This result, consistent with the probability distribution analysis discussed in the Data Description section (see also Appendix A) and similar to the hierarchial cluster analysis, suggests that the Libby samples and the South Carolina samples are both comprised of at least two subgroups, and the China samples remain indistinguishable from South Carolina samples. It should be emphasized that different results can be obtained if different seeds are used; nonetheless, the fact that we can reasonably replicate the hierarchial cluster analysis with the k-cluster analysis suggests that the clustering is reasonable.

As previously noted, with the hierarchial and k-clustering approach, the China samples are indistinguishable from a subset of the South Carolina samples. To see if we could separate out the China samples, we ran three scenarios of a 6 cluster model using the seeds from the previous 5 cluster model plus each of the three China samples as the sixth seed. All of these scenarios resulted in the creation of an orphan (SC 2) with the China samples clustered with the South Carolina in the same manner as seen in the 5 cluster scenario. Thus, the China samples cannot be differentiated from the South Carolina samples using the clustering techniques employed in this study.

Table 4. Seeds used in the k-cluster analysis.

\begin{tabular}{|c|c|}
\hline $\begin{array}{c}\text { No. of } \\
\text { Clusters }\end{array}$ & \multicolumn{1}{|c|}{ Seeds } \\
\hline \hline 4 & SA GS-17, SC GS-11, SC 10, L 7A \\
\hline 5 & SA GS-17, SC GS-11, SC 10, L 7A, L 9A \\
\hline 6 & SA GS-17, SC GS-11, SC 10, L 7A, L 9A, L GS-4 \\
\hline 7 & SA GS-17, SC GS-11, SC 10, L 7A, L 9A, L GS-4, SA GS-1 \\
\hline
\end{tabular}




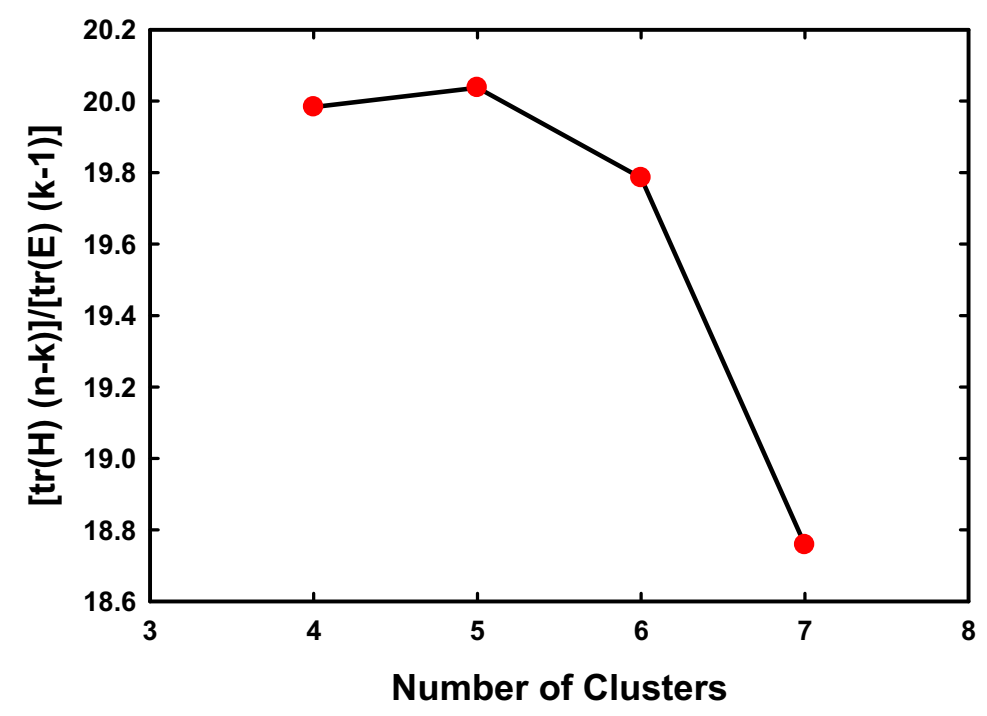

Figure 3. Plot of $\mathrm{c}$ versus number of clusters used in the k-cluster analysis. Maximum values of $\mathrm{c}$ reflect the "best" model.

\subsection{Discriminant Analysis}

Discriminant analysis is a multivariate statistical tool that allows one to address the question of what factors differentiate one category from another. The cluster analysis tools we used in the previous sections consider the distance between a sample and clusters to assign the sample to the nearest cluster to build the groups. This distance is referred to as the Mahalonbis distance.

Discriminant analysis determines what linear combinations of the variables (i.e., roots) best differentiate predefined groups from one another. Wilks' $\Lambda$ is smaller when a variable's contribution to the discriminant function is larger. Once these discriminant functions are defined, they can be transformed to provide a method of classifying additional samples.

We investigate two sets of categories using discriminant analysis. The first set is a four-category model comprised of the original four groups of samples: $\mathrm{L}, \mathrm{SA}, \mathrm{SC}$, and $\mathrm{CH}$. This model allows us to compare the results with the previous work of Gunter et al. (2005). The second set of categories is a sixcategory model comprised of the five groups identified in the cluster analysis but with all of the China samples grouped into a sixth category. Both of these models were run with our set of analytes as well as a subset of these variables that are common with Gunter et al.'s (2005) analyte set, which allows for comparison of our models with than of Gunter et al. (2005).

\subsubsection{Four-Category Models}

The first model that was run was the four-category model (L, SA, SC, CH) with our set of analytes. The sequence of variables added to the model and their corresponding statistics are summarized in Table 5. If the next variable $(\mathrm{Zn})$ is added to model, its coefficient becomes insignificant $(\mathrm{p}=0.110)$. The smallest value of the Wilks' partial lambda $(\Lambda)$ is for $\mathrm{V}$ (Table 5) indicating that this variable contributes the most to discriminating between the groups. The other variables that contribute to discrimination are, in 
increasing order of $\Lambda$ and decreasing order of importance, $\mathrm{Sc}, \mathrm{Sm}, \mathrm{Ni}, \mathrm{K}_{2} \mathrm{O}, \mathrm{Ba}, \mathrm{Ga}, \mathrm{SiO}_{2}, \mathrm{Co}$, and $\mathrm{CaO}$. The tolerances were $>0.10$ indicating a maximum of $90 \%$ redundancy in the discriminating power of the variables.

Table 5. Discriminant function analysis summary for the four category model.

\begin{tabular}{|c|c|c|c|c|c|c|c|}
\hline \multirow{2}{*}{$\mathrm{N}=38$} & \multicolumn{7}{|c|}{$\begin{array}{l}\text { Discriminant Function Analysis Summary (fprinttraceln1) } \\
\text { Step 10, N of vars in model: } 10 \text {; Grouping: Category (4 grps) } \\
\text { Wilks' Lambda: } .00044 \text { approx. F }(30,74)=32.014 p<0.0000\end{array}$} \\
\hline & $\begin{array}{l}\text { Element } \\
\text { Added }\end{array}$ & Wilks' $\Lambda$ & $\begin{array}{c}\text { Wilks' } \\
\text { Partial } \Lambda \\
\end{array}$ & F-Remove & p-Level & Tolerance & $\begin{array}{c}\text { Correlated Variables } \\
\text { Removed }\end{array}$ \\
\hline 1 & $\bar{V}$ & 0.00228 & 0.1910 & 35.29 & 3.8443E-09 & 0.2960 & $\mathrm{TiO}_{2}, \mathrm{MnO}, \mathrm{Na}_{2} \mathrm{O}, \mathrm{Cs}$ \\
\hline 2 & $\mathrm{Sm}$ & 0.00173 & 0.2522 & 24.71 & $1.1951 \mathrm{E}-07$ & 0.2305 & $\mathrm{La}, \mathrm{Ce}$ \\
\hline 3 & Sc & 0.00221 & 0.1972 & 33.93 & 5.6882E-09 & 0.1084 & none \\
\hline 4 & $\mathrm{Ni}$ & 0.00153 & 0.2843 & 20.98 & $5.2351 \mathrm{E}-07$ & 0.1600 & none \\
\hline 5 & $\mathrm{Ga}$ & 0.00074 & 0.5843 & 5.93 & 3.3631E-03 & 0.2003 & $\mathrm{Al}_{2} \mathrm{O}_{3}$ \\
\hline 6 & $\mathrm{~K}_{2} \mathrm{O}$ & 0.00125 & 0.3478 & 15.62 & $6.2577 \mathrm{E}-06$ & 0.1174 & none \\
\hline 7 & $\mathrm{Ba}$ & 0.00087 & 0.5018 & 8.27 & $5.4278 \mathrm{E}-04$ & 0.1009 & none \\
\hline 8 & $\mathrm{SiO}_{2}$ & 0.00064 & 0.6794 & 3.93 & 1.9897E-02 & 0.3953 & none \\
\hline 9 & Co & 0.00063 & 0.6952 & 3.65 & $2.5998 \mathrm{E}-02$ & 0.2398 & none \\
\hline 10 & $\mathrm{CaO}$ & 0.00061 & 0.7110 & 3.39 & $3.3710 \mathrm{E}-02$ & 0.2979 & none \\
\hline
\end{tabular}

The discriminant functions were calculated using canonical analysis. There are three roots that are calculated (number of categories -1$)$. All three of the roots are highly significant $(\mathrm{p}<<0.05)$ and therefore all three roots (Table 6) should be considered.

Table 6. Chi-square tests for successive roots removed for the four-category model.

\begin{tabular}{|c|r|r|r|r|r|r|}
\hline $\begin{array}{c}\text { Roots } \\
\text { Removed }\end{array}$ & $\begin{array}{c}\text { Eigen- } \\
\text { value }\end{array}$ & $\begin{array}{c}\text { Canonical } \\
\text { R }\end{array}$ & $\begin{array}{c}\text { Wilks' } \\
\text { Lambda }\end{array}$ & Chi-Sqr. & df & p-level \\
\hline 0 & 47.36 & 0.9896 & 0.00044 & 232.19 & 30 & $0.000 \mathrm{E}+00$ \\
1 & 13.23 & 0.9642 & 0.02105 & 115.83 & 18 & $2.220 \mathrm{E}-16$ \\
2 & 2.34 & 0.8369 & 0.29958 & 36.16 & 8 & $1.641 \mathrm{E}-05$ \\
\hline \hline
\end{tabular}

The standardized discriminant function coefficients (Table 7) suggest that the first root is dominated by $\mathrm{Sc}, \mathrm{Ni}$, and $\mathrm{Ba}$. The second root is dominated primarily by Sm while the third root is dominated by $\mathrm{Ga}$ and $\mathrm{K}_{2} \mathrm{O}$. The first discriminant function (root) accounts for $75 \%$ of the discriminatory power of the model. The addition of the second function accounts an additional $21 \%$ of the discriminatory power and the addition of the third function adds another $\sim 4 \%$. Thus the three roots account for nearly $100 \%$ of the variability. 
Table 7. Raw and standardized discriminant function coefficients for the four category model.

\begin{tabular}{|l|rrr||rrr|}
\hline & \multicolumn{4}{|c||}{$\begin{array}{c}\text { Raw Coefficients for } \\
\text { Canonical Variables }\end{array}$} & \multicolumn{3}{c|}{$\begin{array}{c}\text { Standardized Coefficients for } \\
\text { Canonical Variables }\end{array}$} \\
\hline Variable & \multicolumn{1}{|c|}{ Root 1 } & \multicolumn{1}{c|}{ Root 2 } & \multicolumn{1}{c|}{ Root 3 } & \multicolumn{1}{c|}{ Root 1 } & \multicolumn{1}{c|}{ Root 2 } & \multicolumn{1}{c|}{ Root 3 } \\
\hline $\mathbf{V}$ & -3.8913 & -1.2663 & 2.52540 & -1.41103 & -0.45918 & 0.91575 \\
$\mathrm{Sm}$ & 1.0846 & -1.4575 & 0.05126 & 1.10442 & -1.48419 & 0.05220 \\
$\mathrm{Sc}$ & -5.4607 & 2.1399 & -1.63977 & -2.49940 & 0.97945 & -0.75053 \\
$\mathrm{Ni}$ & -2.8046 & 0.3588 & 0.50912 & -2.09650 & 0.26821 & 0.38058 \\
$\mathrm{Ga}$ & 0.0862 & -0.7480 & -5.86921 & 0.02502 & -0.21703 & -1.70306 \\
$\mathrm{~K}_{\mathbf{2}} \mathrm{O}$ & 2.5027 & 1.1602 & 1.81737 & 1.89425 & 0.87812 & 1.37552 \\
$\mathrm{Ba}$ & -2.6596 & -0.9911 & -0.89945 & -2.03836 & -0.75957 & -0.68935 \\
$\mathrm{SiO}_{2}$ & -4.2602 & -13.5984 & -5.34365 & -0.26495 & -0.84572 & -0.33234 \\
$\mathrm{Co}$ & -5.3605 & -0.6265 & -0.02755 & -1.13199 & -0.13230 & -0.00582 \\
$\mathrm{CaO}$ & -0.6967 & 0.6461 & 0.07810 & -0.73666 & 0.68318 & 0.08258 \\
\hline \hline Constant & 100.7097 & 59.9839 & 29.89091 & 47.35652 & 13.23402 & 2.33797 \\
Eigenval & 47.3565 & 13.2340 & 2.33797 & -- & -- & -- \\
Cum.Prop & 0.7525 & 0.9628 & 1.00000 & 0.7525 & 0.9628 & 1.00000 \\
\hline
\end{tabular}

From the discriminant equations, the canonical scores for each of the samples can be calculated and plotted (Figure 4). The ellipses are based on the mean \pm 1.5 times the range of the analytes as defined in the Statistica software package (StatSoft, 2006). From the scatter plots, one can see that root 1 is very good at discriminating South Africa samples from the others while root 2 is good at discriminating Libby samples from the South Carolina samples. The samples from China are best discriminated by root 3 .

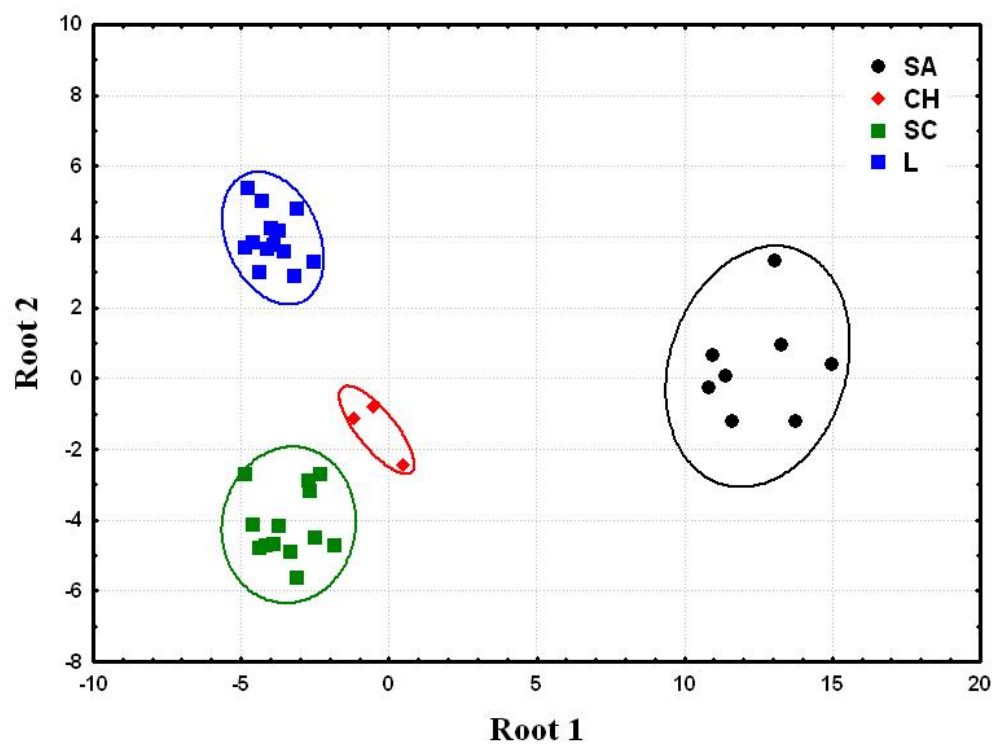



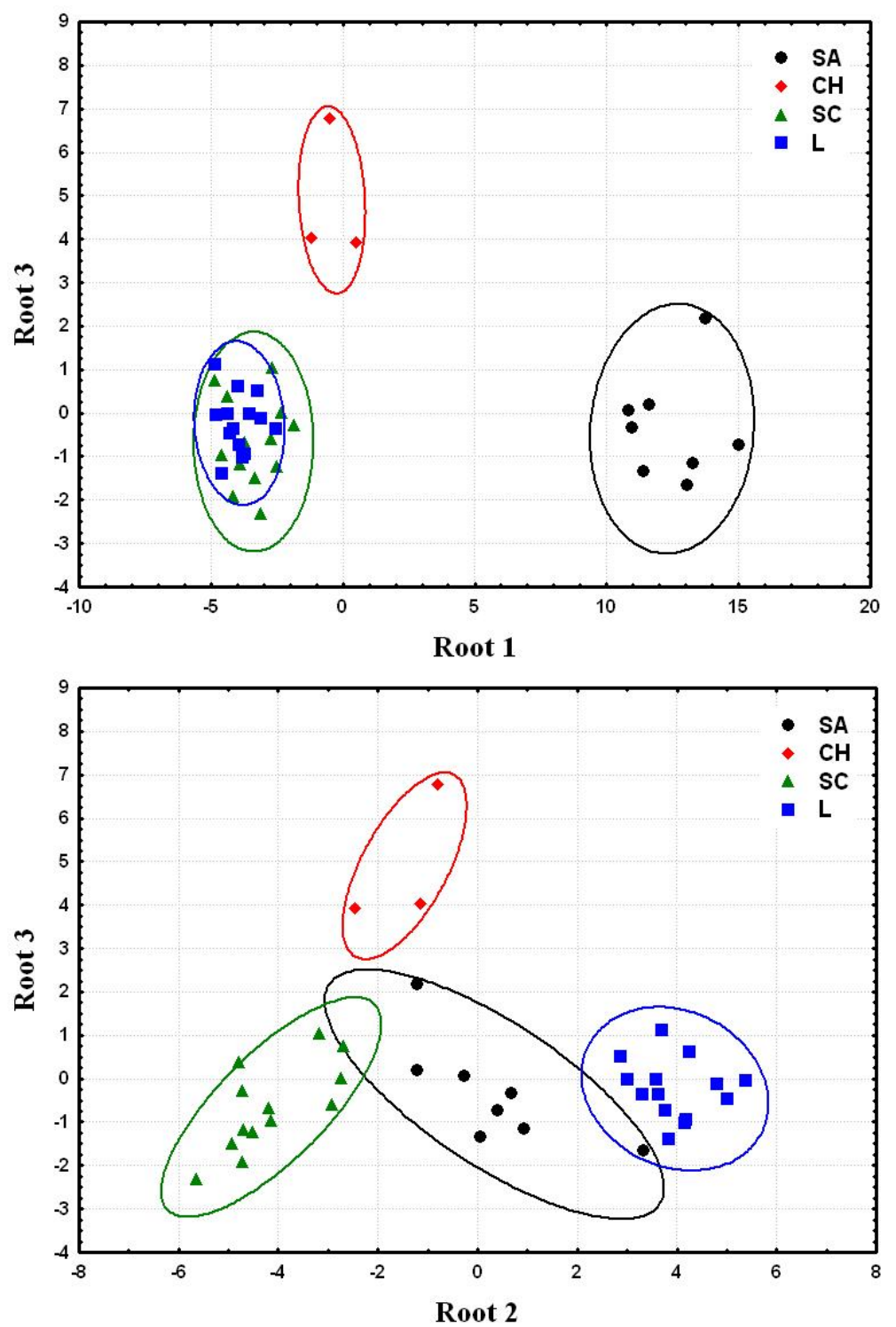

Figure 4. Scatter plots of canonical scores for data from the four-category method.

From the classification functions (Table 8), we can classify each of the samples used in discriminant analysis and calculate post hoc probabilities of the samples belonging to each of the categories. The result of these calculations is that $100 \%$ of the samples are correctly placed into each of their identified categories with probabilities close to unity. The 6 product samples discussed in the Cluster Analysis section were also classified. Samples P2 and P3 have near unit probabilities of belonging to categories SA and SC (South Africa and South Carolina), respectively. The remaining product samples (P1, P4, P5, P6) were identified as belonging to category L (Libby) (Table 9). 
Table 8. Coefficients for the classification functions for the four-category model.

\begin{tabular}{|c|c|c|c|c|}
\hline & $\begin{array}{c}\text { SA } \\
p=.21053\end{array}$ & $\begin{array}{c}\mathrm{CH} \\
\mathrm{p}=.07895 \\
\end{array}$ & $\begin{array}{c}S C \\
p=.34211\end{array}$ & $\begin{array}{c}L \\
p=.36842\end{array}$ \\
\hline$\overline{\overline{\mathbf{V}}}$ & $\overline{359.9}$ & $\bar{~} 425.6$ & 426.6 & 419.5 \\
\hline Sm & -5.5 & -16.6 & -16.2 & -28.5 \\
\hline Sc & 486.2 & 544.1 & 563.7 & 583.3 \\
\hline $\mathbf{N i}$ & 224.5 & 262.7 & 267.2 & 271.9 \\
\hline Ga & 224.8 & 194.1 & 228.5 & 219.9 \\
\hline $\mathrm{K}_{2} \mathrm{O}$ & -237.9 & -262.7 & -283.4 & -274.6 \\
\hline $\mathrm{Ba}$ & 311.1 & 342.4 & 357.9 & 351.0 \\
\hline $\mathrm{SiO}_{2}$ & 3064.2 & 3115.5 & 3194.3 & 3084.1 \\
\hline Co & 991.0 & 1061.1 & 1078.9 & 1076.7 \\
\hline $\mathrm{CaO}$ & 22.9 & 31.1 & 31.0 & 36.7 \\
\hline Constant & -10634.1 & -11818.6 & -12444.9 & -12001.1 \\
\hline
\end{tabular}

Table 9. Classification probabilities for the six products for the four-category model.

\begin{tabular}{|c|cccc|c|}
\hline Sample & $\begin{array}{c}\text { SA } \\
\mathrm{p}=. \mathbf{2 1 0 5 3}\end{array}$ & $\begin{array}{c}\text { CH } \\
\mathrm{p}=. \mathbf{0 7 8 9 5}\end{array}$ & $\begin{array}{c}\text { SC } \\
\mathrm{p}=.34211\end{array}$ & $\begin{array}{c}\mathrm{L} \\
\mathrm{p}=.36842\end{array}$ \\
\hline P1 & 0.00000 & 0.00000 & 0.00000 & 1.00000 \\
P2 & 1.00000 & 0.00000 & 0.00000 & 0.00000 \\
P3 & 0.00000 & 0.00000 & 1.00000 & 0.00000 \\
P4 & 0.00000 & 0.00000 & 0.00000 & 1.00000 \\
P5 & 0.00000 & 0.00000 & 0.00000 & 1.00000 \\
P6 & 0.00000 & 0.00089 & 0.00110 & 0.99800 \\
\hline
\end{tabular}

There are twenty additional vermiculite samples from Gunter et al. (2005) that could be used to test the general approach used in this study. Because that work used a different set of elements than our present study, the discriminant model was reconstructed using data generated from our samples with a common set of elements. The twenty additional samples were then classified and compared to the results reported by Gunter et al. (2005). The common elements between our data set and the two data sets provided by Gunter et al. (2005) are $\mathrm{SiO}_{2}, \mathrm{TiO}_{2}, \mathrm{Al}_{2} \mathrm{O}_{3}, \mathrm{FeO}, \mathrm{MnO}, \mathrm{MgO}, \mathrm{CaO}, \mathrm{Na}_{2} \mathrm{O}, \mathrm{K}_{2} \mathrm{O}, \mathrm{P}_{2} \mathrm{O}_{5}, \mathrm{Ba}, \mathrm{Cr}, \mathrm{Cu}, \mathrm{Ga}, \mathrm{Nb}$, $\mathrm{Ni}, \mathrm{Pb}, \mathrm{Rb}, \mathrm{Sr}, \mathrm{V}, \mathrm{Y}, \mathrm{Zn}$, and $\mathrm{Zr}$. The elements $\mathrm{P}_{2} \mathrm{O}_{5}, \mathrm{Nb}, \mathrm{Pb}$, and $\mathrm{Y}$ were not included in the analyses because some of the samples had concentrations of these analytes below the detection limit. $\mathrm{Zr}$ and $\mathrm{Hf}$ were not included because the samples were potentially contaminated by the zirconia grinder. $\mathrm{Rb}, \mathrm{Sr}$, and $\mathrm{MgO}$ were not included in the analysis because of the significant correlations between the means and the variances for the elements. Therefore, the final set of elements used in the analysis were $\mathrm{SiO}_{2}, \mathrm{TiO}_{2}$, $\mathrm{Al}_{2} \mathrm{O}_{3}, \mathrm{FeO}, \mathrm{MnO}, \mathrm{CaO}, \mathrm{Na}_{2} \mathrm{O}, \mathrm{K}_{2} \mathrm{O}, \mathrm{Ba}, \mathrm{Cr}, \mathrm{Cu}, \mathrm{Ga}, \mathrm{Ni}, \mathrm{Sr}, \mathrm{V}$, and $\mathrm{Zn}$. The values used were the $\mathrm{ln}-$ transformed concentrations reported in Table 2.

The elements were sequentially added to determine the smallest subset of variables that would present information useful for classification of those samples. Details of the model can be found in Appendix D. The selected elements included by increasing values of Wilks' partial $\Lambda$ (hence, in descending order of importance in the model) are $\mathrm{Cr}, \mathrm{V}, \mathrm{Ga}, \mathrm{Zn}, \mathrm{Sc}, \mathrm{FeO} *, \mathrm{~K}_{2} \mathrm{O}$ and $\mathrm{SiO}_{2}$. All of the coefficients are statistically significant $(\mathrm{p}<0.05)$. All three roots (number of categories -1$)$ are highly significant $(\mathrm{p}<<$ 0.05 ) indicating that all three roots need to be considered. The standardized discriminant function 
coefficients suggest that the first root is dominated by $\mathrm{V}$ and $\mathrm{Cr}$ and accounts for $65 \%$ of the discriminatory power of the model. The second root is dominated by $\mathrm{Zn}$ and $\mathrm{FeO}$ and accounts for an additional $26 \%$ to the discriminatory power of the model while the inclusion of the third root, which is dominated by Ga provides an additional $9 \%$ to the discriminatory power. The first root discriminates the $\mathrm{SA}$ and $\mathrm{SC}$ samples from the $\mathrm{CH}$ and $\mathrm{L}$ samples while the second root discriminates the $\mathrm{L}$ samples from the other samples. The third root discriminated the $\mathrm{CH}$ samples from the others. Post hoc classification of the samples used to define the model showed that $100 \%$ of the samples were correctly classified.

The twenty additional samples from the Gunter data set included two vermiculite samples known to be from Libby, one known to be from South Africa, five known to be from South Carolina, four samples of attic insulation and seven samples of garden products. Results of the posteriori classification of these samples are shown in Table 10. Using discriminant analysis, samples of definite known origin from Libby, South Africa, and South Carolina are classified correctly with a probability of model agreement near unity. Garden samples are all ascribed a South African origin, while three of four attic samples are attributed to Libby. The fourth sample, at3UI was classified as originating from South Carolina.

Most of the results of the discriminant analysis results concur with those of Gunter's cluster analysis with a few exceptions. Gunter et al.'s (2005) cluster analysis had several outliers, indicated by a "?" under "Gunter Classification" in Table 10. Discriminant analysis showed that samples SC3UI and SC5UI came from South Carolina, consistent with their reported origin. Samples ga5UI and ga6UI come from South Africa, which is consistent with the remaining garden samples, although the origin of these products cannot be confirmed by the manufacturers. Discriminant analysis of samples at1UI, at2UI and at4UI agree with Gunter's assessment of a Libby origin; however sample at3UI differs. Discriminant analysis suggests this sample comes from South Carolina while Gunter's cluster analysis suggests a Libby origin. One of the key differences between the ore body in Libby versus the ore bodies in South Carolina is the presence of monazite in the latter. Because $\mathrm{La}, \mathrm{Ce}$, and Sm strongly partition into Monazite, the use of one of these elements in discriminant analysis should more accurately separate Libby samples from those originating from South Carolina. The use of Libby vermiculite as attic insulation is relatively common in the Pacific Northwest and Intermountain West. Therefore it is more likely that sample at3UI is from Libby, although this cannot be confirmed.

While both of these models appear to do very well in the post-posteriori classification of the samples, there are differences between the two. The first model, which uses more analytes, shows greater separation of the groups in the plots of the various roots than does the second model. In addition, the square of the Mahalanabis distances between the groups are greater for the first model than for the second model. Further, the eigen values, canonical $\mathrm{R}$ values, and $\chi^{2}$ values for the first model are larger and the $\mathrm{L}$ values are smaller than the model based on the set of elements that are common with Gunter et al. (2005). A key finding is that the China samples can be differentiated from the other three groups using discriminant analysis, regardless of which of the two sets of analytes are used. 
Table 10. Posteriori classification probabilities for the samples analyzed by Gunter et al. (2005) using discriminant analysis. $\mathrm{Li}=$ samples from Libby; at $=$ attic samples; ga= garden products; $\mathrm{SA}=$ samples from South Africa, and $\mathrm{SC}=$ samples from South Carolina.

\begin{tabular}{|c|c|c|c|c|c|c|c|}
\hline Sample & $\begin{array}{c}\text { Reported } \\
\text { Category }\end{array}$ & $\begin{array}{c}\text { Gunter } \\
\text { Class- } \\
\text { ification }\end{array}$ & $\begin{array}{c}\text { This Work } \\
\text { Class- } \\
\text { ification }\end{array}$ & $\begin{array}{c}\text { SA } \\
\mathbf{p}=.21053\end{array}$ & $\begin{array}{c}\mathbf{C H} \\
\mathbf{p}=. \mathbf{0 7 8 9 5}\end{array}$ & $\begin{array}{c}\text { SC } \\
\mathbf{p}=.34211\end{array}$ & $\mathbf{p}=.36842$ \\
\hline Li1UI & $\mathrm{L}$ & $\mathrm{L}$ & $\mathrm{L}$ & 0.000000 & 0.000000 & 0.000001 & 0.999999 \\
Li2UI & $\mathrm{L}$ & $\mathrm{L}$ & $\mathrm{L}$ & 0.000000 & 0.000000 & 0.000002 & 0.999998 \\
at1UI & $?$ & $\mathrm{~L}$ & $\mathrm{~L}$ & 0.000000 & 0.000000 & 0.000224 & 0.999776 \\
at2UI & $?$ & $\mathrm{~L}$ & $\mathrm{~L}$ & 0.000000 & 0.000000 & 0.015272 & 0.984728 \\
at3UI & $?$ & $\mathrm{~L}$ & SC & 0.000000 & 0.000707 & 0.999140 & 0.000152 \\
at4UI & $?$ & $\mathrm{~L}$ & $\mathrm{~L}$ & 0.000000 & 0.000000 & 0.000055 & 0.999945 \\
ga1UI & $?$ & SA & SA & 1.000000 & 0.000000 & 0.000000 & 0.000000 \\
ga2UI & $?$ & SA & SA & 1.000000 & 0.000000 & 0.000000 & 0.000000 \\
ga3UI & $?$ & SA & SA & 1.000000 & 0.000000 & 0.000000 & 0.000000 \\
ga4UI & $?$ & SA & SA & 1.000000 & 0.000000 & 0.000000 & 0.000000 \\
ga5UI & $?$ & $?$ & SA & 1.000000 & 0.000000 & 0.000000 & 0.000000 \\
ga6UI & $?$ & $?$ & SA & 1.000000 & 0.000000 & 0.000000 & 0.000000 \\
ga7UI & $?$ & SA & SA & 1.000000 & 0.000000 & 0.000000 & 0.000000 \\
SA1UI & SA & SA & SA & 1.000000 & 0.000000 & 0.000000 & 0.000000 \\
SC1UI & SC & SC & SC & 0.000000 & 0.000000 & 0.999998 & 0.000002 \\
SC2UI & SC & SC & SC & 0.000000 & 0.000000 & 1.000000 & 0.000000 \\
SC3UI & SC & $?$ & SC & 0.000000 & 0.000059 & 0.999927 & 0.000014 \\
SC4UI & SC & SC & SC & 0.000000 & 0.000000 & 0.999999 & 0.000001 \\
SC5UI & SC & $?$ & SC & 0.000000 & 0.000000 & 1.000000 & 0.000000 \\
SC6UI & SC & SC & SC & 0.000000 & 0.000000 & 1.000000 & 0.000000 \\
\hline
\end{tabular}

\subsubsection{Six-Category Models}

Our four-category discriminant analysis approach to classify vermiculite samples as being from Libby, South Carolina, South Africa or China is useful; however, it does appear to contradict results from the probability plots and the cluster analysis, which suggest that the Libby and South Carolina groups are comprised of two subgroups. To develop a more consistent model, we performed discriminant analysis on the five groups defined by the k-cluster analysis. In addition, we considered the China samples to be a sixth group to determine if it was possible to discriminate these samples from the other groups. More detailed results of the discriminant analysis are provided in Appendix E. The sequence of variables added to the model (Table 11) is similar to that of the four-category system except that $\mathrm{Zn}$ is added and Co and $\mathrm{SiO}_{2}$ are removed. When the next variable $\left(\mathrm{SiO}_{2}\right)$ is added, both $\mathrm{SiO}_{2}$ and Co become insignificant $(\mathrm{p}>$ 0.05). The Wilks' partial $\Lambda$ is smallest for $\mathrm{K}_{2} \mathrm{O}$ indicating that this variable has the greatest discriminating power. This is followed by $\mathrm{Sm}, \mathrm{Ba}, \mathrm{Ni}, \mathrm{Sc}$, and $\mathrm{V}$ in decreasing discriminatory power. In general, the tolerances are much larger in the six category model than in the four-category model suggesting less redundancy in the variables. All five roots calculated by the canonical analysis (Table 12) are highly significant $(\mathrm{p}<<0.05)$ and therefore all five roots should be considered. 
Table 11. Discriminant function analysis summary for six-category model.

\begin{tabular}{|c|c|c|c|c|c|c|c|}
\hline \multirow{2}{*}{ Step } & \multicolumn{7}{|c|}{$\begin{array}{l}\text { Discriminant Function Analysis Summary (fprinttraceln1) } \\
\text { Step 9, N of vars in model: } 9 \text {; Grouping: Category ( } 6 \text { grps) } \\
\text { Wilks' Lambda: } .00002 \text { approx. F }(45,110)=24.143 p<0.0000\end{array}$} \\
\hline & $\begin{array}{l}\text { Element } \\
\text { Added }\end{array}$ & Wilks' $\Lambda$ & $\begin{array}{c}\text { Wilks' }^{\prime} \\
\text { Partial } \Lambda \\
\end{array}$ & F-Remove & p-Level & Tolerance & $\begin{array}{c}\text { Correlated Variables } \\
\text { Removed }\end{array}$ \\
\hline 1 & $\mathrm{~V}$ & 0.000071 & 0.3299 & 9.75 & 3.4945E-05 & 0.5914 & $\mathrm{TiO}_{2}, \mathrm{MnO}, \mathrm{Na}_{2} \mathrm{O}, \mathrm{Cs}$ \\
\hline 2 & Sm & 0.000130 & 0.1804 & 21.81 & $3.2768 \mathrm{E}-08$ & 0.2678 & $\mathrm{La}, \mathrm{Ce}$ \\
\hline 3 & Sc & 0.000079 & 0.2975 & 11.33 & 1.0769E-05 & 0.2285 & none \\
\hline 4 & $\mathrm{Ni}$ & 0.000083 & 0.2846 & 12.07 & $6.4804 \mathrm{E}-06$ & 0.5591 & none \\
\hline 5 & $\mathrm{Ga}$ & 0.000049 & 0.4821 & 5.16 & 2.3657E-03 & 0.3182 & $\mathrm{Al}_{2} \mathrm{O}_{3}$ \\
\hline 6 & $\mathrm{~K}_{2} \mathrm{O}$ & 0.000140 & 0.1672 & 23.90 & 1.3487E-08 & 0.0971 & none \\
\hline 7 & $\mathrm{Ba}$ & 0.000088 & 0.2673 & 13.16 & $3.1512 \mathrm{E}-06$ & 0.1182 & none \\
\hline 8 & $\mathrm{Zn}$ & 0.000038 & 0.6215 & 2.92 & 3.3653E-02 & 0.5474 & $\mathrm{Cu}$ \\
\hline 9 & $\mathrm{CaO}$ & 0.000037 & 0.6376 & 2.73 & 4.3387E-02 & 0.6756 & none \\
\hline
\end{tabular}

Table 12. Chi-square tests for successive roots removed for the six-category model.

\begin{tabular}{|c|r|r|r|r|r|r|}
\hline $\begin{array}{c}\text { Roots } \\
\text { Removed }\end{array}$ & $\begin{array}{c}\text { Eigen- } \\
\text { value }\end{array}$ & $\begin{array}{r}\text { Canonical } \\
\text { R }\end{array}$ & $\begin{array}{c}\text { Wilks' } \\
\text { Lambda }\end{array}$ & Chi-Sqr. & df & p-level \\
\hline 0 & 58.62 & 0.9916 & 0.000023 & 314.44 & 45 & $0.000 \mathrm{E}+00$ \\
1 & 14.56 & 0.9673 & 0.001400 & 193.84 & 32 & $0.000 \mathrm{E}+00$ \\
2 & 6.10 & 0.9269 & 0.021797 & 112.87 & 21 & $1.432 \mathrm{E}-14$ \\
3 & 2.52 & 0.8459 & 0.154733 & 55.05 & 12 & $1.774 \mathrm{E}-07$ \\
4 & 0.84 & 0.6753 & 0.543986 & 17.96 & 5 & $2.996 \mathrm{E}-03$ \\
\hline
\end{tabular}

The standardized discriminant function coefficients (Table 13) suggest that the first root is dominated by $\mathrm{K}_{2} \mathrm{O}$ and $\mathrm{Ba}$ while the second root is dominated by Sm. The third root appears to be an even combination of $\mathrm{Ga}, \mathrm{Ni}, \mathrm{K}_{2} \mathrm{O}$, and $\mathrm{Zn}$. The fourth and fifth roots are dominated by $\mathrm{Ga}$ and $\mathrm{K}_{2} \mathrm{O}$, respectively. The first discriminant function accounts for $71 \%$ of the discriminatory power of the model. The successive addition of the second through the fifth roots respectively adds about $18,7,3$, and $1 \%$ to the discriminatory power of the model. One obvious feature of the six-category model is that both Libby and South Carolina are split into two subgroups while China and South Africa remain as intact groups. This discriminatory power is particularly well-shown in the scatter plots of root 2 versus root 1 and root 3 versus root 1 (Figure 5). The first root helps to discriminate SA and SC-1 from the other groups, and $\mathrm{CH}$ from SC-1, SC-2, and SA. The second root helps to discriminate L-1 and L-2 from the other categories and to a lesser extent $\mathrm{SC}-1$ from the other categories. Root 3 helps to discriminate $\mathrm{CH}$ from the other categories, L-2 from L-1, and SC-1 from SC-2. 
Table 13. Raw and standardized discriminant function coefficients for six-category model.

\begin{tabular}{|c|c|c|c|c|c|c|c|c|c|c|}
\hline \multirow[b]{2}{*}{ Variable } & \multicolumn{5}{|c|}{$\begin{array}{l}\text { Raw Coefficients for } \\
\text { Canonical Variables }\end{array}$} & \multicolumn{5}{|c|}{$\begin{array}{c}\text { Standardized Coefficients for } \\
\text { Canonical Variables }\end{array}$} \\
\hline & Root 1 & Root 2 & Root 3 & Root 4 & Root 5 & Root 1 & Root 2 & Root 3 & Root 4 & Root 5 \\
\hline$\overline{\mathbf{V}}$ & 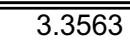 & 0.39857 & -1.44983 & -1.5702 & -0.47662 & 0.92563 & 0.10992 & $=0.399840$ & $=0.433042$ & $\overline{\overline{446}}$ \\
\hline Sm & -0.4869 & -1.87879 & 0.28619 & -0.0 & & 314 & -1.72909 & 0.263382 & -0 . & 335 \\
\hline Sc & & & & & & & & & & \\
\hline $\mathrm{Ni}$ & & 644 & -1 & & & & & -0.7 & & \\
\hline Ga & & -0.59144 & 377 & & & & & & & \\
\hline $\mathrm{K}_{2} \mathrm{O}$ & -3.8471 & 1.30642 & -1.13204 & -0.9936 & -1.48704 & -2.58650 & 0.87832 & -0.761091 & -0.668008 & 9762 \\
\hline $\mathrm{Ba}$ & 3.9162 & -1.55981 & 0.93788 & 0.4717 & -0 & 060 & -0.90835 & 0.546171 & 0.27 & -0 . \\
\hline $\mathrm{Zn}$ & 1.7426 & -0.56622 & -3.24252 & 0.6700 & -1.79642 & 0.38576 & -0.12534 & -0.717797 & 0.148309 & -0.397674 \\
\hline $\mathrm{CaO}$ & & 0.65764 & 0.37499 & -0.8376 & & 0.05726 & 0.46218 & 0.263539 & -0.588639 & 0.237399 \\
\hline & .4706 & -3.63909 & 1212.18640 & $\overline{12.1094}$ & $\overline{-3.4}$ & "58.62018 & 1414.56459 & "6.098748 & 2.515637 & 0.838283 \\
\hline Eig & 58.6202 & 14.56459 & 6.09875 & 2.5156 & 0.83828 & -- & -- & -- & -- & -- \\
\hline Cum.Prob. & 0.7094 & 0.88561 & 0.95941 & 0.9899 & 1.00000 & 0.70937 & 0.88561 & 0.959414 & 0.989856 & 1.000000 \\
\hline
\end{tabular}



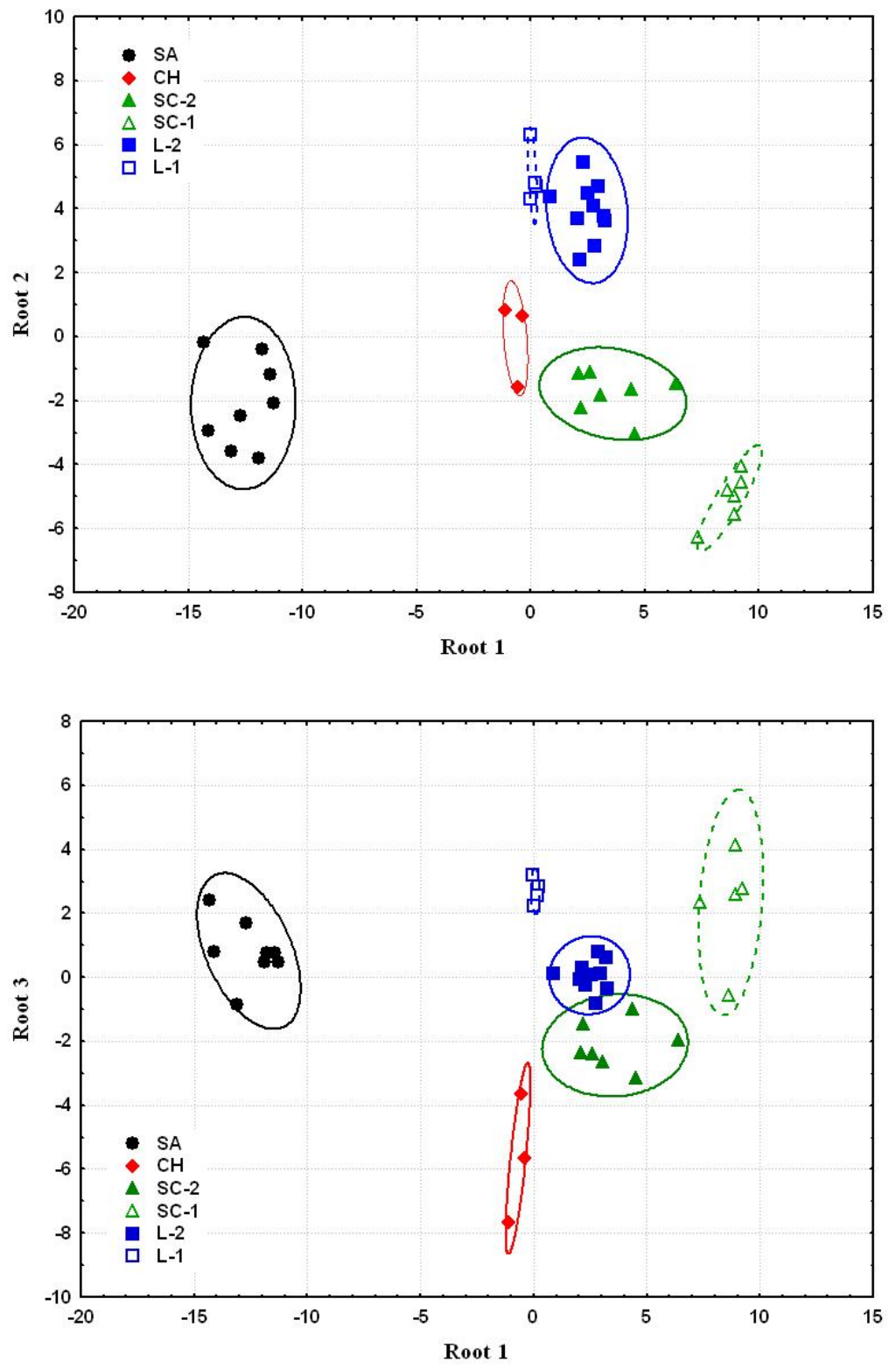

Figure 5. Scatter plots of canonical scores for data from six-category model. Ellipses define the compositional fields of each category based on their roots. 
Using the six-category classification functions (Table 14), we classified posteriori probabilities for each of the samples used in the discriminant analysis and calculated probabilities of the 6 product samples belonging to each of the categories (Table 15). Included in the analysis was sample SA GS-1, which was classified as a Libby sample under some of the cluster analysis scenarios. As with the four-category model, $100 \%$ of the six-category samples were correctly identified with the probabilities in all cases being very close to unity. Thus, the model is able to distinguish each of the groups extremely well. The results for the products were identical to the results obtained by both cluster analysis and the four-category discriminant analysis.

Table 14. Coefficients for the classification functions for the six-category model.

\begin{tabular}{|c|c|c|c|c|c|c|}
\hline & $\begin{array}{c}\text { SA } \\
p=.21053\end{array}$ & $\begin{array}{c}\mathrm{CH} \\
\mathrm{p}=.07895\end{array}$ & $\begin{array}{c}\text { SC-2 } \\
p=.18421\end{array}$ & $\begin{array}{c}\text { SC-1 } \\
p=.15789\end{array}$ & $\begin{array}{c}L-2 \\
p=.26316\end{array}$ & $\begin{array}{c}L-1 \\
p=.10526\end{array}$ \\
\hline $\mathbf{V}$ & 128.17 & 183.47 & 185.69 & 197.76 & 180.63 & 175.41 \\
\hline Sm & -40.14 & -51.57 & -49.28 & -44.53 & -59.11 & -58.86 \\
\hline Sc & 256.31 & 302.87 & 319.79 & 329.99 & 331.81 & 323.98 \\
\hline $\mathrm{Ni}$ & 106.25 & 132.60 & 132.11 & 123.01 & 133.71 & 128.13 \\
\hline Ga & 97.86 & 64.02 & 108.68 & 123.44 & 110.78 & 103.78 \\
\hline $\mathrm{K}_{2} \mathrm{O}$ & -199.61 & -230.72 & -260.67 & -285.53 & -249.28 & -239.38 \\
\hline $\mathrm{Ba}$ & 205.23 & 241.25 & 265.47 & 294.33 & 254.64 & 243.96 \\
\hline $\mathrm{Zn}$ & 197.56 & 238.29 & 232.72 & 231.91 & 224.41 & 205.64 \\
\hline $\mathrm{CaO}$ & 11.73 & 13.67 & 12.38 & 12.56 & 15.54 & 21.17 \\
\hline Constant & -1732.97 & -2486.32 & -2752.38 & -3037.80 & -2677.25 & -2456.60 \\
\hline
\end{tabular}

Table 15. Posteriori calculations of classification probabilities for the six products and SA GS-1 using the six-category model.

\begin{tabular}{|c|c|c|c|c|c|c|c|}
\hline \multirow[b]{2}{*}{ Samples } & \multicolumn{7}{|c|}{$\begin{array}{l}\text { Posterior Probabilities (fprinttraceln1) } \\
\text { Incorrect classifications are marked with * }\end{array}$} \\
\hline & $\begin{array}{c}\text { Observed } \\
\text { Classif. }\end{array}$ & $\begin{array}{c}\mathrm{CH} \\
p=.07895\end{array}$ & $\begin{array}{c}L 1 \\
p=.10526\end{array}$ & $\begin{array}{c}L 2 \\
p=.26316\end{array}$ & $\begin{array}{c}\text { SA } \\
p=.21053\end{array}$ & $\begin{array}{c}\text { SC1 } \\
p=.15789\end{array}$ & $\begin{array}{c}\text { SC2 } \\
p=.18421\end{array}$ \\
\hline P1 & --- & 0.00000 & 0.00000 & 1.00000 & 0.00000 & 0.00000 & 0.0000 \\
\hline P2 & --- & 0.00000 & 0.00000 & 0.00000 & 1.00000 & 0.00000 & 0.00000 \\
\hline P3 & --- & 0.00000 & 0.00000 & 0.00000 & 0.00000 & 0.00000 & 1.00000 \\
\hline P4 & -- & 0.00000 & 0.00007 & 0.99993 & 0.00000 & 0.00000 & 0.00000 \\
\hline P5 & --- & 0.00000 & 0.00000 & 1.00000 & 0.00000 & 0.00000 & 0.00000 \\
\hline P6 & --- & 0.00000 & 0.15155 & 0.84141 & 0.00000 & 0.00000 & 0.00703 \\
\hline
\end{tabular}

The six-category model was also run using the Gunter et al., (2005) analyte set. The analytes in the model in order of decreasing importance (increasing Wilks' partial $\Lambda$ ) are $\mathrm{Ni}, \mathrm{Zn}, \mathrm{V}, \mathrm{SiO}_{2}, \mathrm{FeO}, \mathrm{Ga}, \mathrm{Sc}$, and $\mathrm{Ba}$. All five roots are highly significant $(\mathrm{p}<<0.05)$ and therefore all five should be considered. The standardized coefficients for the canonical variables suggest that the first, second, third, and fourth roots are dominated by $\mathrm{FeO}, \mathrm{Zn}, \mathrm{Ni}$, and $\mathrm{Ga}$, respectively while the fifth root is evenly influenced by $\mathrm{SiO}_{2}, \mathrm{Ga}$, $\mathrm{FeO}$, and $\mathrm{Zn}$. For the samples used to define the model, 100\% were properly classified. For the 20 Gunter et al. (2005) samples, all of the samples that were classified as SA in the four-category model 
were also classified as SA in the six-category model. The samples that were classified as L samples in the four-category model were classified as L2 in the six-category model. The samples previously classified as SC were classified as SC2 in the six-category model except for SC5UI, which was classified as SC1. Sample at3UI which was classified as SC in the four-category model has a $61 \%$ chance of being classified as $\mathrm{CH}, 35 \%$ of being SC2, and $4 \%$ of being $\mathrm{L} 2$ in the six-category model, thus it likely remains incorrectly classified.

As with the four-category model, the six-category model using the analyte set in this study appears to have greater discriminating power than the model based on the Gunter et al. (2005) analyte set. Again, this conclusion is based on the better separation of the groups in the plots of the various roots, the larger squared Mahalonbis distances, and the smaller Wilks' $\Lambda$.

\section{Conclusions}

Several conclusions can be drawn from this work:

1. Probability plots suggest that there may be at least two subcategories in the Libby and the South Carolina samples.

2. While cluster analysis is useful for group classification when there is no prior knowledge about a sample's origin, it is highly sensitive to the linkage algorithm chosen. Ward's linkage provides the best classification for this data set based upon knowledge of the origin of the samples.

3. Because of the differences in accessory minerals between the deposits, REE's such as La, Ce, $\mathrm{Sc}$, and Sm are highly diagnostic in provenance determination. Samarium is particularly useful for distinguishing samples from Libby as Sm is highly depleted in Libby samples.

4. Hierarchial cluster analysis and k-cluster analysis both support that notion that there are subcategories in the Libby and South Carolina samples.

5. Cluster analysis suggests that there are five clusters in the data corresponding to the South African samples, two subsets of the Libby samples, a subset of the South Carolina samples, and a second subset of the South Carolina samples combined with the China samples. Neither the hierarchical nor the non-hierarchical clustering methods tested in this work was capable of distinguishing the China samples from the South Carolina samples.

6. Discriminant analysis shows that the four ore provenances can be uniquely differentiated from one another using three roots (factors). The first root is dominated by $\mathrm{Sc}, \mathrm{Ni}$, and $\mathrm{Ba}$, the second root by Sm, and the third root by $\mathrm{Ga}$ and $\mathrm{K}_{2} \mathrm{O}$. Unknown samples can be assigned a provenance with a probability computed from the model.

7. Discrimination can also be achieved using a subset of our analytes that is consistent with that used by Gunter et al. (2005). The first root is dominated by $\mathrm{V}$ and $\mathrm{Cr}$, the second by $\mathrm{Zn}$ and $\mathrm{FeO}$, and the third root is dominated by $\mathrm{Ga}$. The discrimination is better with our full analyte set than with the smaller analyte set of Gunter et al. (2005).

8. Groups from a six-category model comprised of one group of South Africa samples, one group of China samples, two groups of Libby samples, and two groups of South Carolina samples can be differentiated using five roots for both the full analyte set and the reduced analyte set.

9. The six-category discriminant model developed from the full analyte set best represents the data since it is consistent with the results of the probability plots and the cluster analysis. For the five 
roots describing this model, the first root is dominated by $\mathrm{K}_{2} \mathrm{O}$ and $\mathrm{Ba}$ while the second root is dominated by Sm. The third root appears to be an even combination of $\mathrm{Ga}, \mathrm{Ni}, \mathrm{K}_{2} \mathrm{O}$, and $\mathrm{Zn}$. The fourth and fifth roots are dominated by $\mathrm{Ga}$ and $\mathrm{K}_{2} \mathrm{O}$, respectively.

10. Because discriminant analysis allows for clear differentiation between the primary suppliers of vermiculite to the United States, this technique can be used to determine the relative risk of asbestos contamination based on the ore's origin. 


\section{References}

ATSDR, 2002, The Community Environmental Health Project in Libby, Montana, in Hazardous Substances and Public Health, Part 1.

Boettcher, A.L., 1967, The Rainy Creek alkaline-ultramafic igneous complex near Libby, Montana: I. Ultramafic rocks and fenite: Journal of Geology, v. 75, p.526-553.

Deer, W.A., Howie, R.A. and J. Zussman, 1992, An Introduction to the Rock Forming Minerals, $2^{\text {nd }}$ Edition, Longman Scientific and Technical, 696p.

Frank D, and L. Edmund, 2001, Feasibility for Identifying Mineralogical and Geochemical Tracers from Vermiculite Ore Deposits, EPA 910-R-01-002, U.S. Environmental Protection Agency, Region 10, Seattle, WA

Guilbert, J.M., Park Jr., C.F., 1986, The Geology of Ore Deposits, W.H. Freeman and Company, New York, 985p.

Gunter, M.E., Singleton, E., Bandli, B.R., Lowers, H.A., and G.P. Meeker, 2005, Differentiation of commercial vermiculite based on statistical analysis of bulk chemical data: Fingerprinting vermiculite from Libby, Montana U.S.A., American Mineralogist, v. 90, p. 749-754.

Gunter, M.E., and E. Singleton, 2003, Crystal Chemistry in the Attic: Differentiating Commercial Vermiculite from Libby, Montana from other Commercial Vermiculites on the Basis of "Whole-Rock" Chemical Analysis, Abstracts with Programs, Geological Society of America, v. 35, no.6, p. 620.

Johnson, D.M., Hooper, P.R. and R.M. Conrey, 1999, XRF Analysis of Rocks and Minerals for Major and Trace Elements on a Single Low Dilution Li-tetraborate Fused Bead, in Advances in X-ray Analysis, v. 41, p. $854-867$.

Kawabe, I., 1977. A stochastic model of fractional crystallization and its application to the Japanese geosynclinal basalt, Mathematical Geology, v. 9, no. 1, 39-53.

Libby, S.C., 1975, The Origin of Potassic Ultramafic Rocks in the Enoree "Vermiculite" District, South Carolina: University Park, PA, Pennsylvania State University unpublished thesis, 116p.

Lowers, H.A., and G.P. Meeker, 2004, Electron Probe Microanalysis as a Tool for Identifying Vermiculite Sources, Microscopy and Microanalysis.

McPherson, G., 2001, Applying and Interpreting Statistics, Springer-Verlag, New York, 640p.

Milligan, G.W., Cooper, M.C., 1985, An Examination of Procedures for Determining the Number of Clusters in a Data Set, Psychometrika, v. 50, no. 2, p. 159-179.

Mojena, R., 1977, Hierarchical grouping methods and stopping rules: An evaluation, Computer Journal, v. 20 , no. 4 , p. $359-363$.

Morgan, B.J.T. and A P.G. Ray, 1995, Non-uniqueness and Inversions in Cluster Analysis, Applied Statistics, v. 44, no. 1, p. 117-134. 
Potter, M.J., 2000, Vermiculite, in U.S. Geological Survey Minerals Yearbook, 83.1-83.4.

Rencher, A.C., 2002, Methods of Multivariate Analysis, Wiley-Interscience, New Jersey.

Schneider, A., 1999, Uncivil Action: A Town Left to Die, Seattle Post-Intelligencer, Nov 18, 1999.

StatSoft, Inc. (2006). STATISTICA (data analysis software system), version 7.1. www.statsoft.com.

StatSoft, Inc. (2007). Electronic Statistics Textbook. Tulsa, OK: StatSoft. WEB:

http://www.statsoft.com/textbook/stathome.html.

Systat Software, Inc. (2007). Statistics I, San Jose, CA. www.systat.com

Sun S. S., McDonough, W.F., 1989, Chemical and isotopic systematics of oceanic basalts: implications for mantle composition and processes. In: Saunders, A.D. and Norry, M. (eds), Magmatism in Ocean Basins. Geological Society of London Special Publication v.42, p. 313-345

U.S. Environmental Protection Agency, 1985, Exposure Assessment for Asbestos-Contaminated Vermiculite. EPA 560/5-85-013, U.S. Environmental Protection Agency, Washington, D.C.

U.S. Geological Survey, 2006, Vermiculite statistics, in Kelly, T.D., and Matos, G.R., comps., Historical statistics for mineral and material commodities in the United States: U.S. Geological Survey Data Series 140, available online at http://pubs.usgs.gov/ds/2005/140/. (Accessed 12/14/07.)

Williams, T.J., Gunter, M.E., Jones, B., Singleton, E., 2003, Preliminary Observations on the Provenance of Industrial Vermiculites by Powder X-ray Diffraction, Abstracts with Programs, Geological Society of America, v. 35, no.6, p. 620.

Wright, K., 1998, Geochemistry and Petrology of the tuff of McMullen Creek, Cassia County Idaho, Idaho State University M.S. Thesis, 172p. 
Appendix A

Summary Statistics 


\begin{tabular}{|c|c|c|c|c|c|c|c|c|c|c|}
\hline & \multicolumn{5}{|c|}{ Means } & \multicolumn{5}{|c|}{ Standard Deviations } \\
\hline & SA & $\mathrm{CH}$ & SC & $\mathbf{L}$ & All Grps & SA & $\mathrm{CH}$ & SC & $\mathbf{L}$ & All Grps \\
\hline $\mathrm{SiO}_{2}$ & 3.809336 & 3.824437 & 3.876127 & 3.775172 & 3.820791 & 0.036393 & 0.002959 & 0.065377 & 0.073868 & 0.073805 \\
\hline $\mathrm{TiO}_{2}$ & 0.019161 & 0.526237 & 0.832966 & 0.174501 & 0.394831 & 896 & 0.073812 & 0.336246 & 0.334960 & 0907 \\
\hline $\mathrm{Al}_{2} \mathrm{O}_{3}$ & 2.309454 & 2.526623 & 2.527845 & 2.418164 & 2.441362 & 0.035489 & 0.094341 & 0.198985 & 0.423765 & 0.289549 \\
\hline $\mathrm{FeO}$ & 2.007325 & 2.259633 & 2.339286 & 2.197073 & 2.210717 & 0.055912 & 0.172765 & 0.205457 & 0.251465 & 0.230499 \\
\hline $\mathrm{MnO}$ & -2.92791 & -2.347197 & -1.731358 & -2.333723 & -2.253806 & 0.101930 & 0.066166 & 0.583250 & 0.139198 & 0.562687 \\
\hline $\mathrm{MgO}$ & 3.263843 & 2.83723 & 2.6718 & 3.091087 & 2.963975 & 0.023249 & 0.181455 & 0.376797 & 0.090707 & 0.328133 \\
\hline $\mathrm{CaO}$ & 1.168229 & 1.574407 & 1.402339 & 0.721355 & 1.115748 & 0.683581 & 0.544937 & 0.615059 & 1.509077 & 1.064260 \\
\hline $\mathrm{Na}_{2} \mathrm{O}$ & -2.645446 & -1.28382 & -0.6024 & -1.405935 & -1.382351 & 0.18 & 0.715569 & 0.920588 & 0.306553 & 446 \\
\hline $\mathrm{K}_{2} \mathrm{O}$ & 1. & 1.572483 & 1.003054 & 1.732347 & 1.463079 & 0.067733 & 0.098832 & 1.152936 & 0.516970 & 711 \\
\hline $\mathrm{Ba}$ & 6.132254 & 6.760357 & 7.419586 & 7.684082 & 7.19397 & 0.240951 & 0.170802 & 1.149478 & 0.529929 & 0.952631 \\
\hline $\mathrm{Ce}$ & 3.468545 & 3.24667 & 4.328862 & 1.37216 & 2.972995 & 1.239657 & 1.256664 & 0.864760 & 0.609245 & 1.556853 \\
\hline Co & 4.216251 & 4.080523 & 3.918926 & 4.198216 & 4.097175 & 0.105580 & 0.128716 & 0.244393 & 0.230095 & 0.243089 \\
\hline $\mathrm{Cr}$ & 5.459674 & 6.682223 & 6.175684 & 7.087224 & 6.400765 & 0.119716 & 0.298661 & 1.431814 & 0.498026 & 1.074054 \\
\hline Cs & 2.433655 & 1.197877 & 0.650945 & 1.532221 & 1.394112 & 0.158796 & 0.177211 & 0.533973 & 0.320387 & 0.757001 \\
\hline $\mathrm{Cu}$ & 3.091361 & 3.62608 & 3.777596 & 1.696444 & 2.854424 & 0.915008 & 0.186601 & 0.747994 & 1.098601 & 1.277897 \\
\hline $\mathrm{Ga}$ & 2.582509 & 2.376433 & 2.776348 & 2.593058 & 2.63644 & 0.108983 & 0.260299 & 0.243696 & 0.385449 & 0.301780 \\
\hline La & 2.507134 & 2.527397 & 3.471813 & -0.169074 & 1.852784 & 1.310820 & 1.040573 & 0.873723 & 1.077766 & 1.906974 \\
\hline $\mathrm{Ni}$ & 5.144616 & 6.231283 & 5.132414 & 5.139552 & 5.224366 & 0.145111 & 0.114894 & 1.203971 & 0.331659 & 0.776365 \\
\hline $\mathrm{Rb}$ & 6.044889 & 5.817997 & 4.669662 & 5.413933 & 5.324046 & 0.070449 & 0.192611 & 1.162617 & 0.495495 & 0.901794 \\
\hline Sc & 1.997867 & 2.165887 & 2.901339 & 2.897751 & 2.651751 & 0.286453 & 0.245814 & 0.450425 & 0.554214 & 0.590661 \\
\hline $\mathrm{Sm}$ & 1.287143 & 1.121356 & 2.027684 & -1.822001 & 0.381924 & 1.329488 & 0.988971 & 0.842625 & 0.976860 & 1.990945 \\
\hline $\mathrm{Sr}$ & 4.788851 & 6.037207 & 5.977637 & 4.569326 & 5.213218 & 0.697986 & 1.020647 & 1.142948 & 0.615129 & 1.077622 \\
\hline V & 3.289914 & 5.119277 & 5.285472 & 4.481825 & 4.556153 & 0.422829 & 0.046011 & 0.435091 & 0.269377 & 0.825948 \\
\hline $\mathrm{Zn}$ & 4.293389 & 4.87699 & 4.743639 & 3.985201 & 4.379952 & 0.110496 & 0.160769 & 0.246413 & 0.400474 & 0.454791 \\
\hline Valid N & 8 & 7 & 13 & 14 & 38 & 8 & & 13 & 14 & 38 \\
\hline
\end{tabular}




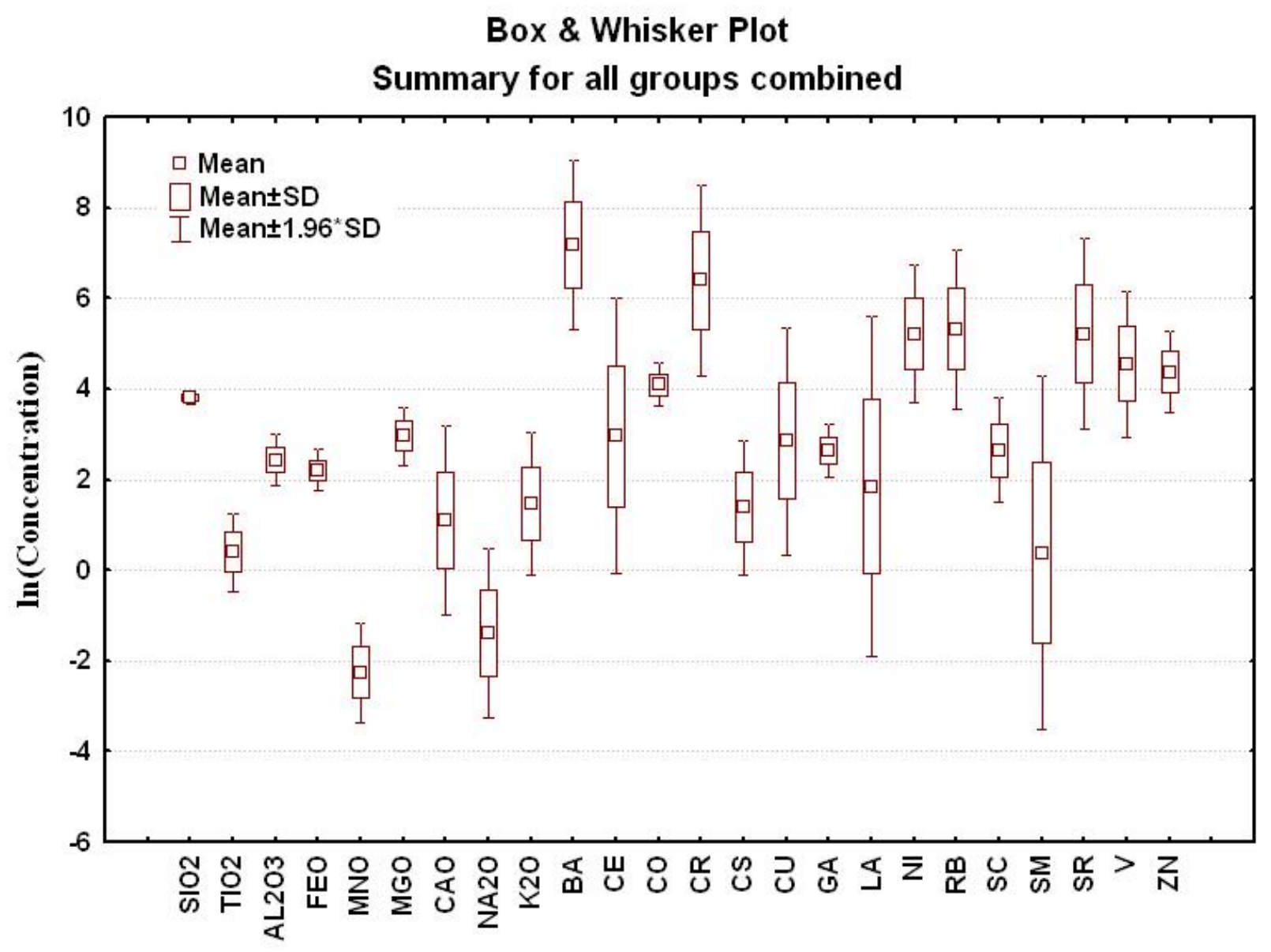



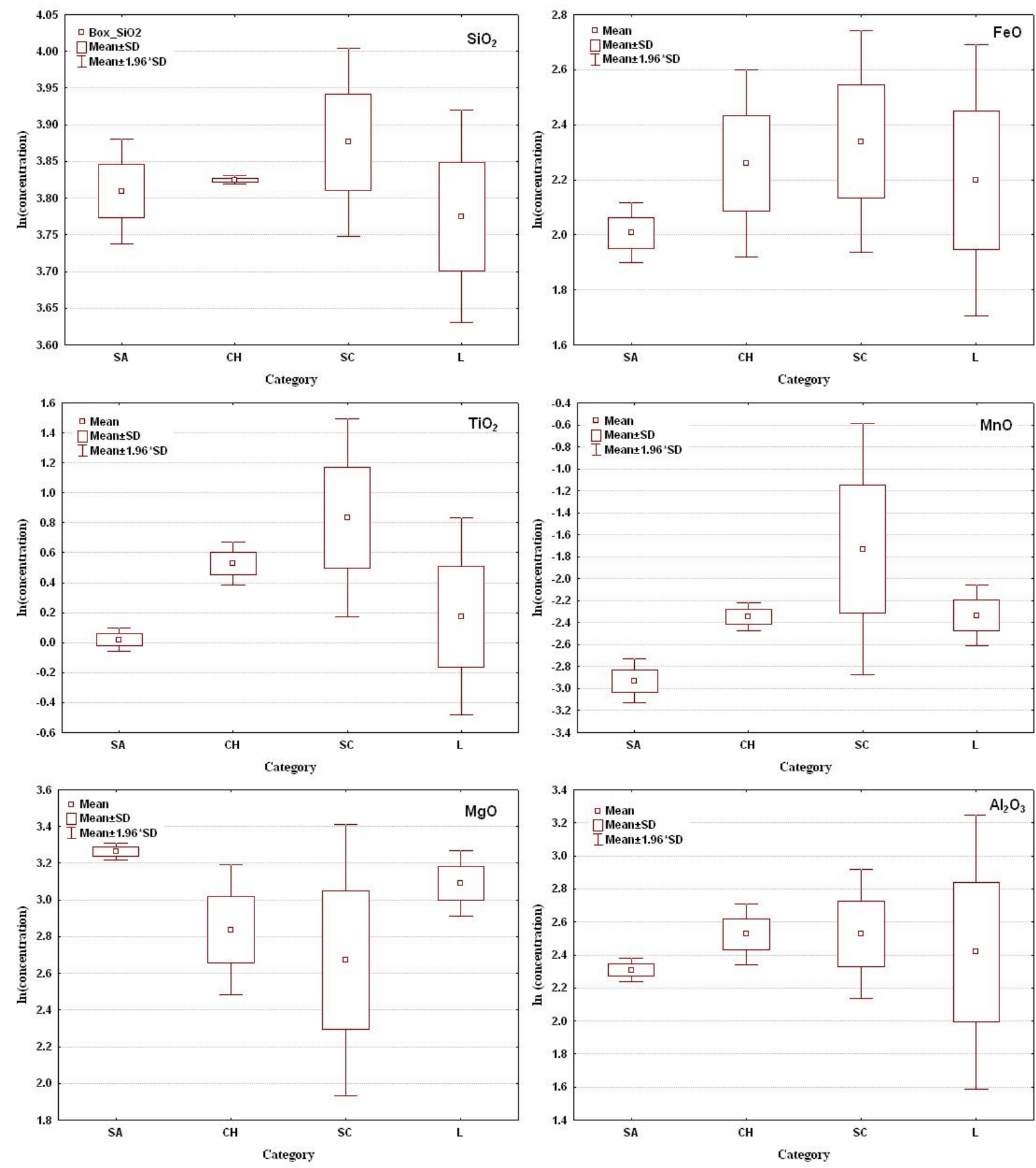

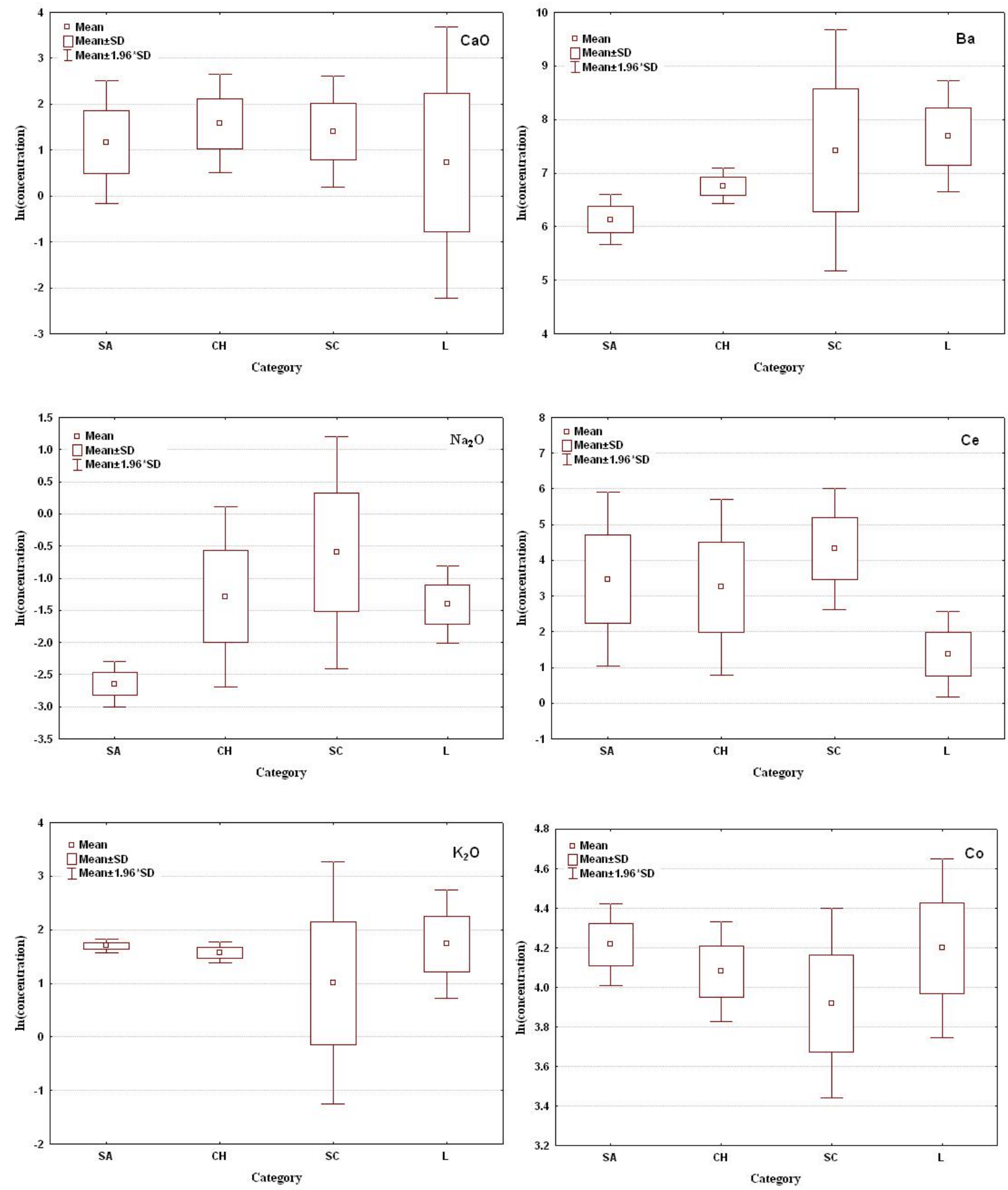

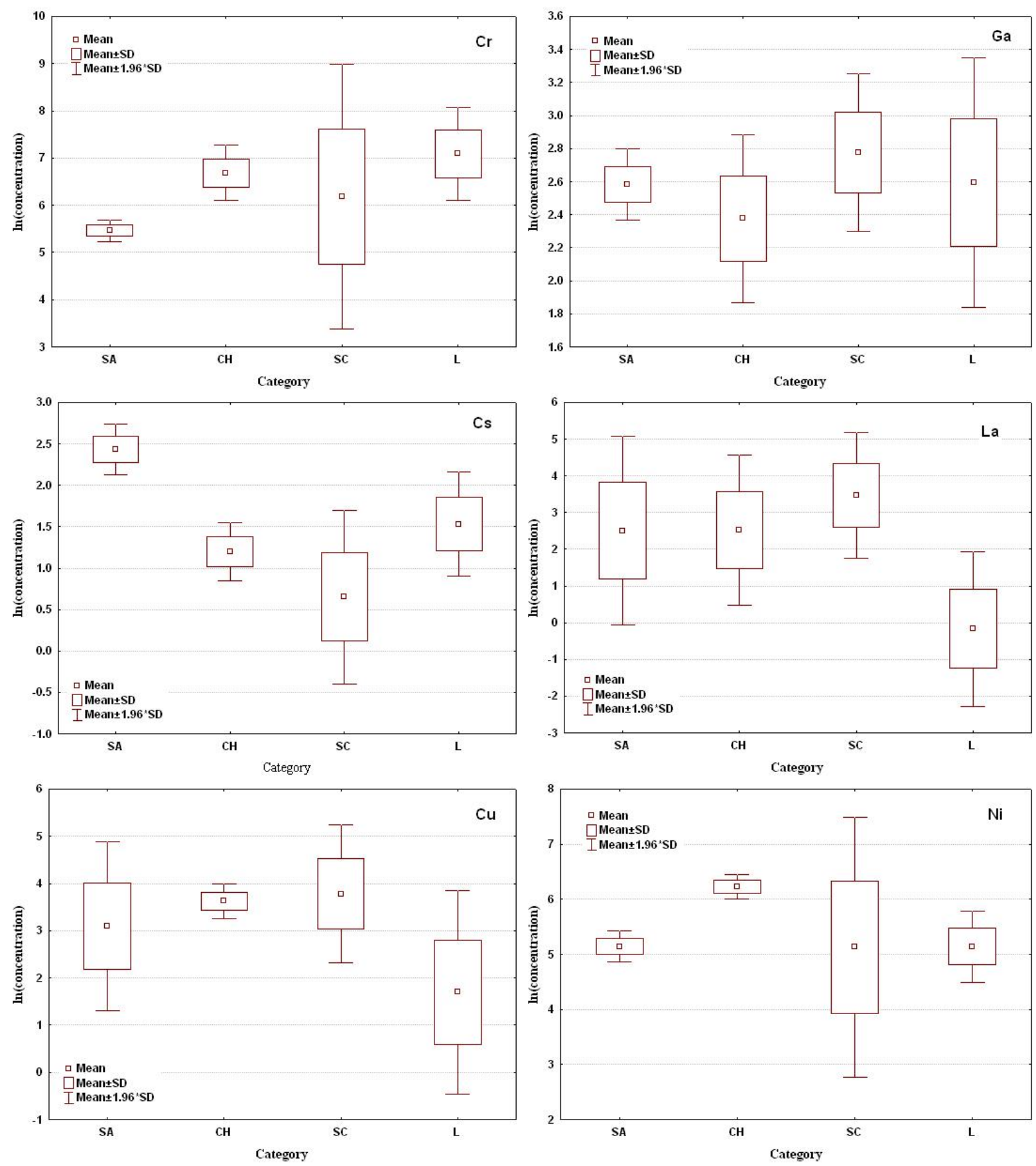

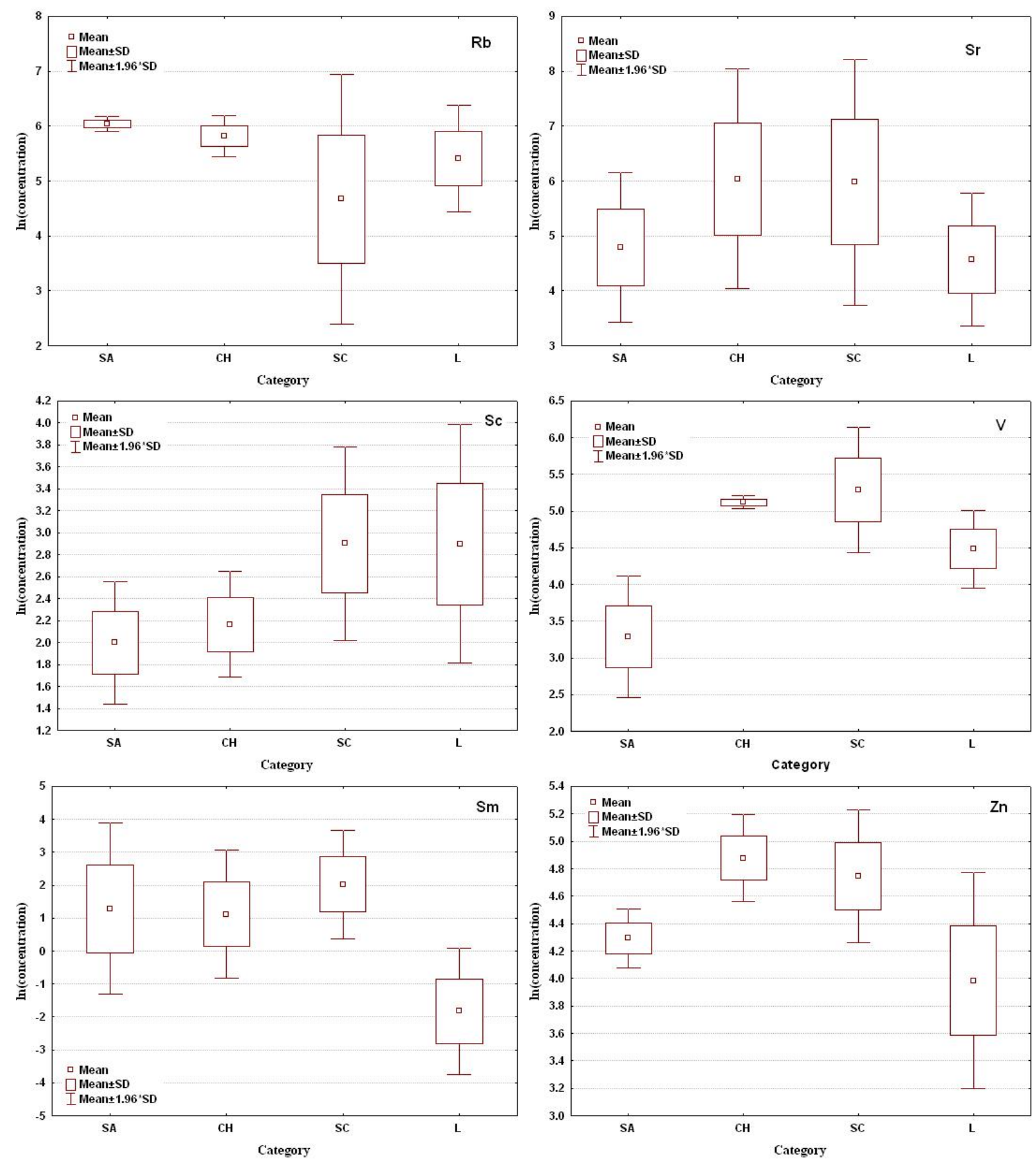


\begin{tabular}{|c|c|c|c|c|c|c|c|c|c|c|c|c|c|c|c|c|c|c|c|c|c|c|}
\hline & $\mathrm{SIO}_{2}$ & $\mathrm{TiO}_{2}$ & $\mathrm{Al}_{2} \mathrm{O}_{3}$ & $\mathrm{FeO}$ & MnO & $\mathrm{MgO}$ & $\mathrm{CaO}$ & $\mathrm{Na}_{2} \mathrm{O}$ & $\mathrm{K}_{2} \mathrm{O}$ & $\mathrm{P}_{2} \mathrm{O}_{5}$ & $\mathrm{Ba}$ & $\mathrm{Ce}$ & Co & $\mathrm{Cr}$ & Cs & $\mathrm{Cu}$ & Eu & $\mathbf{G a}$ & $\mathrm{Hf}$ & $\mathrm{La}$ & Lu & Nd \\
\hline$\overline{\mathrm{SiO}_{2}}$ & 1.000 & & & & & & & & & & & & & & & & & & & & & \\
\hline $\mathrm{TiO}_{2}$ & 0.029 & 1.000 & & & & & & & & & & & & & & & & & & & & \\
\hline $\mathrm{Al}_{2} \mathrm{O}_{3}$ & -0.391 & 0.696 & 1.000 & & & & & & & & & & & & & & & & & & & \\
\hline $\mathrm{FeO}$ & -0.259 & 0.746 & 0.620 & 1.000 & & & & & & & & & & & & & & & & & & \\
\hline $\mathrm{MnO}$ & 0.280 & 0.576 & 0.282 & 0.486 & 1.000 & & & & & & & & & & & & & & & & & \\
\hline $\mathrm{MgO}$ & -0.385 & -0.636 & -0.114 & -0.399 & -0.541 & 1.000 & & & & & & & & & & & & & & & & \\
\hline $\mathrm{CaO}$ & 0.514 & -0.116 & -0.582 & -0.276 & 0.011 & -0.402 & 1.000 & & & & & & & & & & & & & & & \\
\hline $\mathrm{Na}_{2} \mathrm{O}$ & 0.298 & 0.489 & 0.135 & 0.197 & 0.399 & -0.633 & 0.236 & 1.000 & & & & & & & & & & & & & & \\
\hline $\mathrm{K}_{2} \mathrm{O}$ & -0.584 & 0.040 & 0.431 & -0.032 & -0.208 & 0.047 & -0.353 & -0.126 & 1.000 & & & & & & & & & & & & & \\
\hline $\mathrm{P}_{2} \mathrm{O}_{5}$ & 0.369 & 0.289 & -0.108 & 0.043 & 0.126 & -0.461 & 0.517 & 0.054 & -0.226 & 1.000 & & & & & & & & & & & & \\
\hline $\mathrm{Ba}$ & -0.293 & 0.534 & 0.592 & 0.390 & 0.316 & -0.426 & -0.257 & 0.560 & 0.550 & -0.380 & 1.000 & & & & & & & & & & & \\
\hline $\mathrm{Ce}$ & 0.355 & 0.417 & -0.003 & 0.113 & 0.191 & -0.511 & 0.395 & 0.213 & -0.211 & 0.851 & -0.217 & 1.000 & & & & & & & & & & \\
\hline Co & -0.512 & -0.322 & 0.226 & 0.079 & -0.200 & 0.634 & -0.493 & -0.594 & 0.140 & -0.450 & -0.142 & -0.597 & 1.000 & & & & & & & & & \\
\hline $\mathrm{Cr}$ & -0.089 & -0.052 & 0.305 & -0.125 & 0.134 & 0.350 & -0.381 & 0.125 & 0.166 & -0.587 & 0.321 & -0.459 & 0.191 & 1.000 & & & & & & & & \\
\hline Cs & -0.476 & -0.522 & 0.023 & -0.393 & -0.584 & 0.596 & -0.263 & -0.701 & 0.635 & -0.186 & -0.156 & -0.281 & 0.549 & -0.011 & 1.000 & & & & & & & \\
\hline $\mathrm{Cu}$ & 0.244 & 0.453 & 0.298 & 0.355 & 0.386 & -0.257 & 0.173 & -0.059 & -0.177 & 0.651 & -0.208 & 0.658 & -0.134 & -0.147 & -0.168 & 1.000 & & & & & & \\
\hline Eu & 0.497 & 0.305 & -0.154 & -0.048 & 0.131 & -0.455 & 0.464 & 0.145 & -0.280 & 0.893 & -0.350 & 0.867 & -0.646 & -0.498 & -0.297 & 0.591 & 1.000 & & & & & \\
\hline Ga & -0.347 & 0.668 & 0.841 & 0.568 & 0.321 & -0.185 & -0.504 & 0.081 & 0.435 & -0.015 & 0.532 & 0.158 & 0.119 & 0.129 & 0.064 & 0.371 & -0.025 & 1.000 & & & & \\
\hline $\mathrm{Hf}$ & 0.425 & 0.675 & 0.161 & 0.422 & 0.578 & -0.749 & 0.212 & 0.574 & -0.351 & 0.483 & 0.203 & 0.586 & -0.442 & -0.248 & -0.686 & 0.357 & 0.490 & .274 & 1.000 & & & \\
\hline La & 0.403 & 0.388 & -0.060 & 0.062 & 0.155 & -0.495 & 0.393 & 0.200 & -0.240 & 0.853 & -0.266 & 0.887 & -0.568 & -0.508 & -0.296 & 0.528 & 0.869 & 0.038 & 0.600 & 1.000 & & \\
\hline Lu & 0.441 & 0.592 & 0.072 & 0.341 & 0.525 & -0.726 & 0.263 & 0.431 & -0.289 & 0.616 & 0.042 & 0.706 & -0.609 & -0.302 & -0.592 & 0.484 & 0.654 & 0.179 & 0.759 & 0.679 & 1.000 & \\
\hline Nd & 0.498 & 0.204 & -0.226 & -0.109 & 0.094 & -0.385 & 0.569 & 0.093 & -0.314 & 0.758 & -0.348 & 0.675 & -0.467 & -0.458 & -0.262 & 0.409 & 0.742 & -0.144 & 0.479 & 0.801 & 0.520 & 1.000 \\
\hline $\mathrm{Nb}$ & 0.102 & 0.536 & 0.275 & 0.423 & 0.576 & -0.496 & 0.095 & 0.554 & -0.174 & 0.079 & 0.407 & 0.221 & -0.291 & 0.240 & -0.637 & 0.206 & 0.112 & 0.203 & 0.562 & 0.142 & 0.471 & 0.024 \\
\hline $\mathrm{Ni}$ & 0.070 & -0.071 & 0.195 & -0.160 & -0.018 & 0.435 & -0.303 & -0.177 & -0.141 & -0.033 & -0.274 & -0.085 & 0.239 & 0.624 & 0.001 & 0.215 & -0.029 & -0.008 & -0.089 & -0.078 & -0.098 & -0.071 \\
\hline $\mathrm{Pb}$ & 0.328 & 0.641 & 0.293 & 0.485 & 0.567 & -0.581 & 0.215 & 0.399 & -0.267 & 0.510 & 0.127 & 0.571 & -0.339 & -0.058 & -0.554 & 0.653 & 0.444 & 0.277 & 0.636 & 0.436 & 0.675 & 0.370 \\
\hline $\mathbf{R b}$ & -0.522 & -0.136 & 0.283 & -0.202 & -0.362 & 0.195 & -0.256 & -0.367 & 0.920 & -0.027 & 0.228 & -0.108 & 0.224 & 0.061 & 0.787 & -0.059 & -0.133 & 0.294 & -0.434 & -0.109 & -0.365 & -0.146 \\
\hline Sc & 0.150 & 0.171 & -0.237 & 0.107 & 0.338 & -0.575 & 0.237 & 0.556 & -0.068 & -0.116 & 0.409 & 0.086 & -0.564 & -0.077 & -0.535 & -0.284 & 0.069 & -0.092 & 0.381 & 0.075 & 0.420 & 0.069 \\
\hline Sm & 0.483 & 0.297 & -0.196 & -0.041 & 0.139 & -0.486 & 0.493 & 0.144 & -0.286 & 0.899 & -0.361 & 0.920 & -0.641 & -0.533 & -0.293 & 0.554 & 0.937 & -0.048 & 0.540 & 0.927 & 0.699 & 0.838 \\
\hline $\mathrm{Sr}$ & 0.460 & 0.357 & -0.182 & 0.002 & 0.219 & -0.765 & 0.707 & 0.615 & -0.197 & 0.682 & 0.109 & 0.654 & -0.731 & -0.374 & -0.501 & 0.213 & 0.616 & -0.161 & 0.608 & 0.679 & 0.602 & 0.608 \\
\hline $\mathrm{Ta}$ & 0.148 & 0.244 & 0.013 & 0.095 & 0.368 & -0.338 & 0.015 & 0.385 & -0.098 & -0.153 & 0.392 & 0.040 & -0.276 & 0.069 & -0.394 & -0.171 & -0.048 & 0.096 & 0.500 & 0.017 & 0.205 & 0.004 \\
\hline Tb & 0.277 & 0.324 & -0.060 & 0.060 & 0.216 & -0.423 & 0.291 & 0.267 & -0.206 & 0.640 & -0.100 & 0.811 & -0.498 & -0.385 & -0.282 & 0.456 & 0.652 & 0.101 & 0.591 & 0.687 & 0.539 & 0.497 \\
\hline Th & 0.352 & 0.244 & -0.109 & -0.055 & 0.069 & -0.309 & 0.295 & 0.063 & -0.242 & 0.625 & -0.294 & 0.660 & -0.325 & -0.373 & -0.197 & 0.356 & 0.597 & -0.017 & 0.474 & 0.753 & 0.472 & 0.796 \\
\hline $\mathbf{U}$ & 0.246 & 0.347 & 0.104 & 0.175 & 0.418 & -0.432 & 0.034 & 0.425 & -0.161 & -0.013 & 0.349 & 0.060 & -0.313 & 0.119 & -0.499 & -0.064 & 0.025 & 0.117 & 0.504 & 0.054 & 0.289 & 0.041 \\
\hline V & 0.131 & 0.809 & 0.477 & 0.695 & 0.711 & -0.698 & -0.033 & 0.651 & -0.069 & 0.089 & 0.575 & 0.180 & -0.350 & 0.131 & -0.700 & 0.308 & 0.124 & 0.433 & 0.597 & 0.130 & 0.581 & 0.006 \\
\hline $\mathbf{Y}$ & 0.541 & 0.205 & -0.247 & -0.106 & 0.127 & -0.406 & 0.595 & 0.106 & -0.345 & 0.737 & -0.341 & 0.616 & -0.431 & -0.450 & -0.288 & 0.395 & 0.708 & -0.168 & 0.501 & 0.751 & 0.501 & 0.983 \\
\hline $\mathrm{Yb}$ & 0.346 & 0.446 & 0.099 & 0.149 & 0.335 & -0.462 & 0.292 & 0.323 & -0.237 & 0.591 & -0.071 & 0.762 & -0.532 & -0.188 & -0.420 & 0.585 & 0.669 & 0.179 & 0.512 & 0.601 & 0.670 & 0.474 \\
\hline $\mathrm{Zn}$ & 0.130 & 0.743 & 0.542 & 0.664 & 0.465 & -0.425 & -0.065 & 0.045 & -0.093 & 0.571 & 0.001 & 0.566 & -0.143 & -0.186 & -0.304 & 0.807 & 0.508 & 0.529 & 0.532 & 0.540 & 0.600 & 0.360 \\
\hline $\mathrm{Zr}$ & 0.519 & 0.626 & 0.061 & 0.317 & 0.491 & -0.771 & 0.370 & 0.486 & -0.330 & 0.653 & 0.069 & 0.708 & -0.583 & -0.385 & -0.622 & 0.419 & 0.658 & 0.169 & 0.885 & 0.713 & 0.762 & 0.587 \\
\hline
\end{tabular}




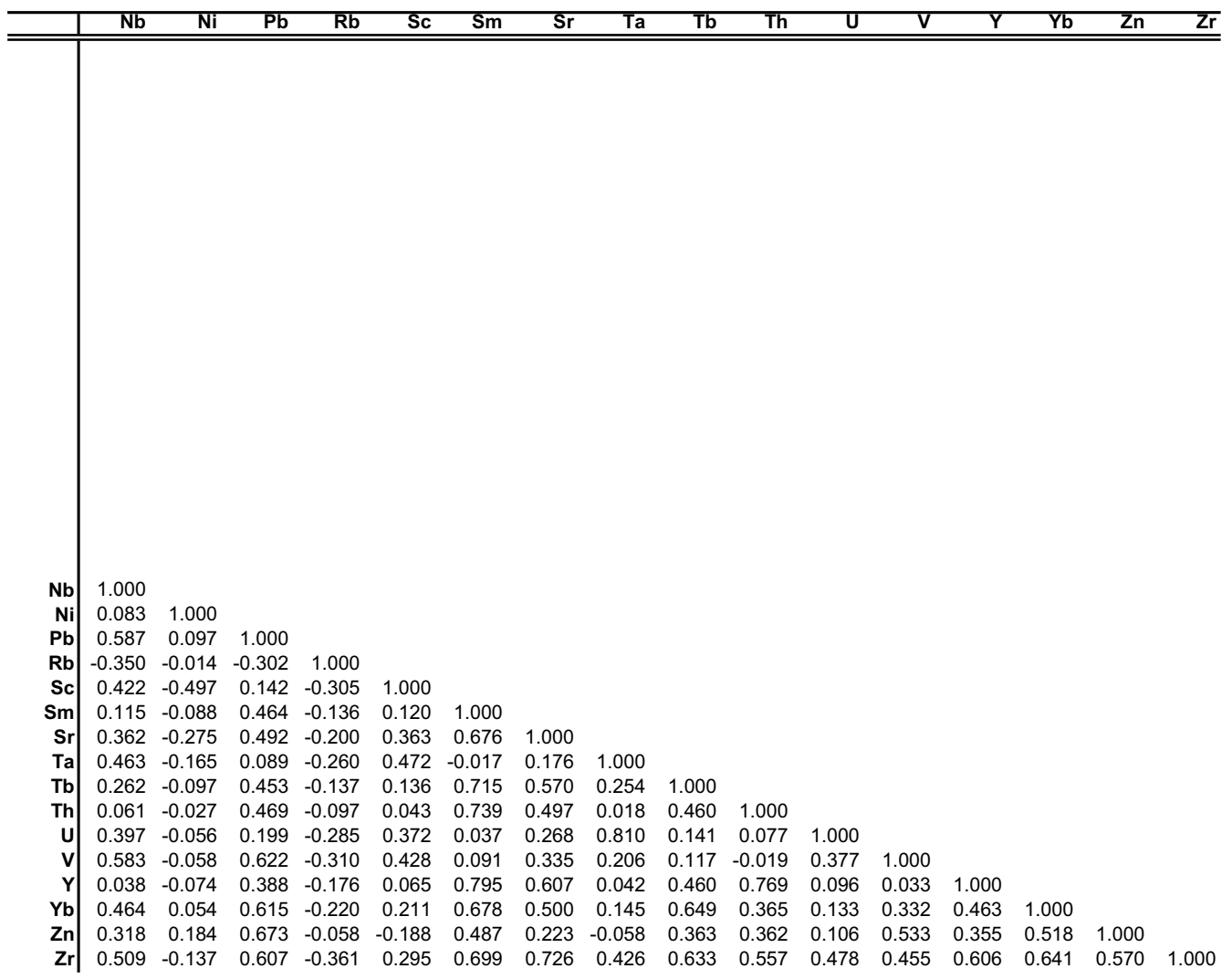


Categorized Probability Plot: $\mathrm{SlO} 2$
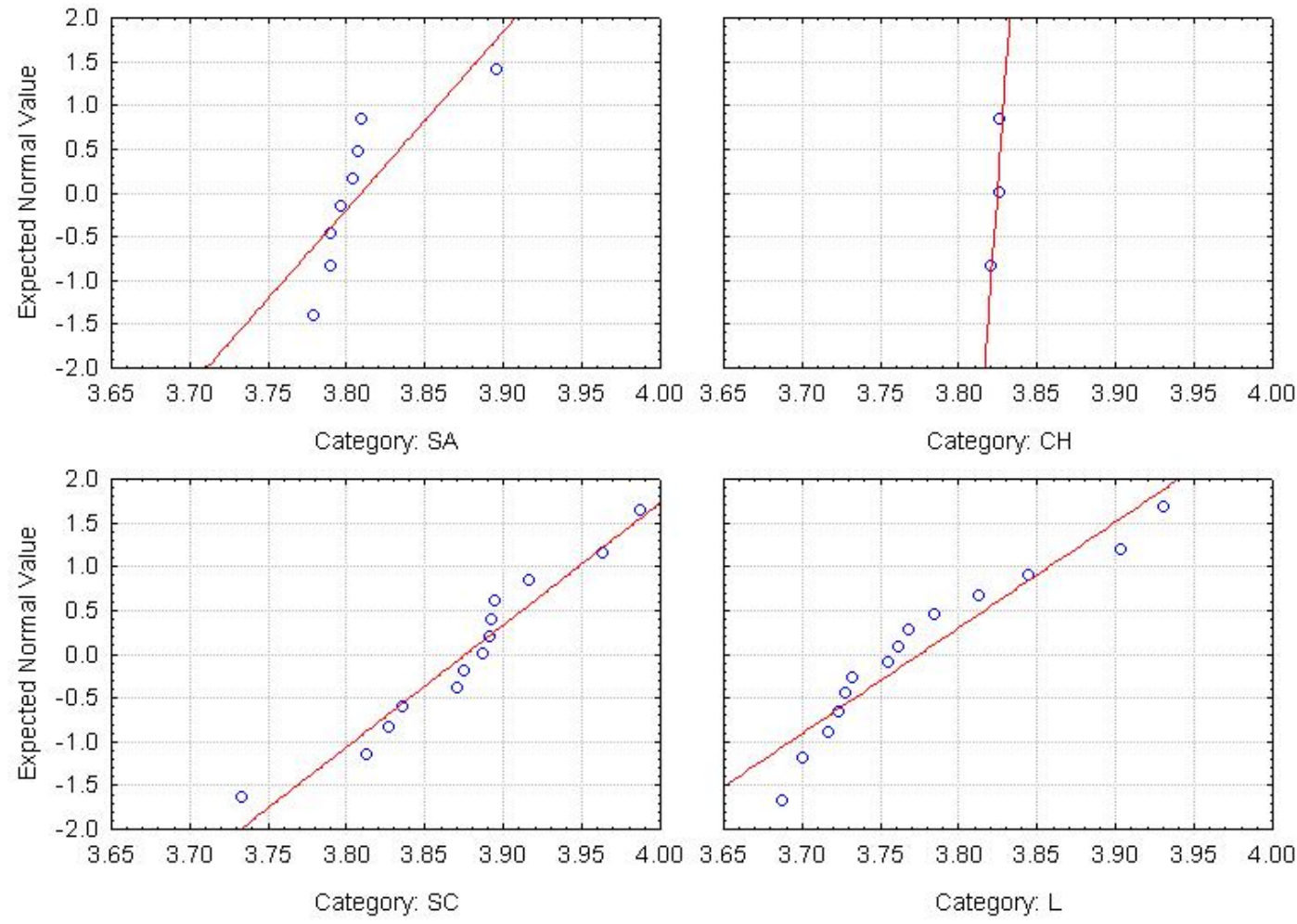

Categorized Probability Plot: $\mathrm{TIO} 2$
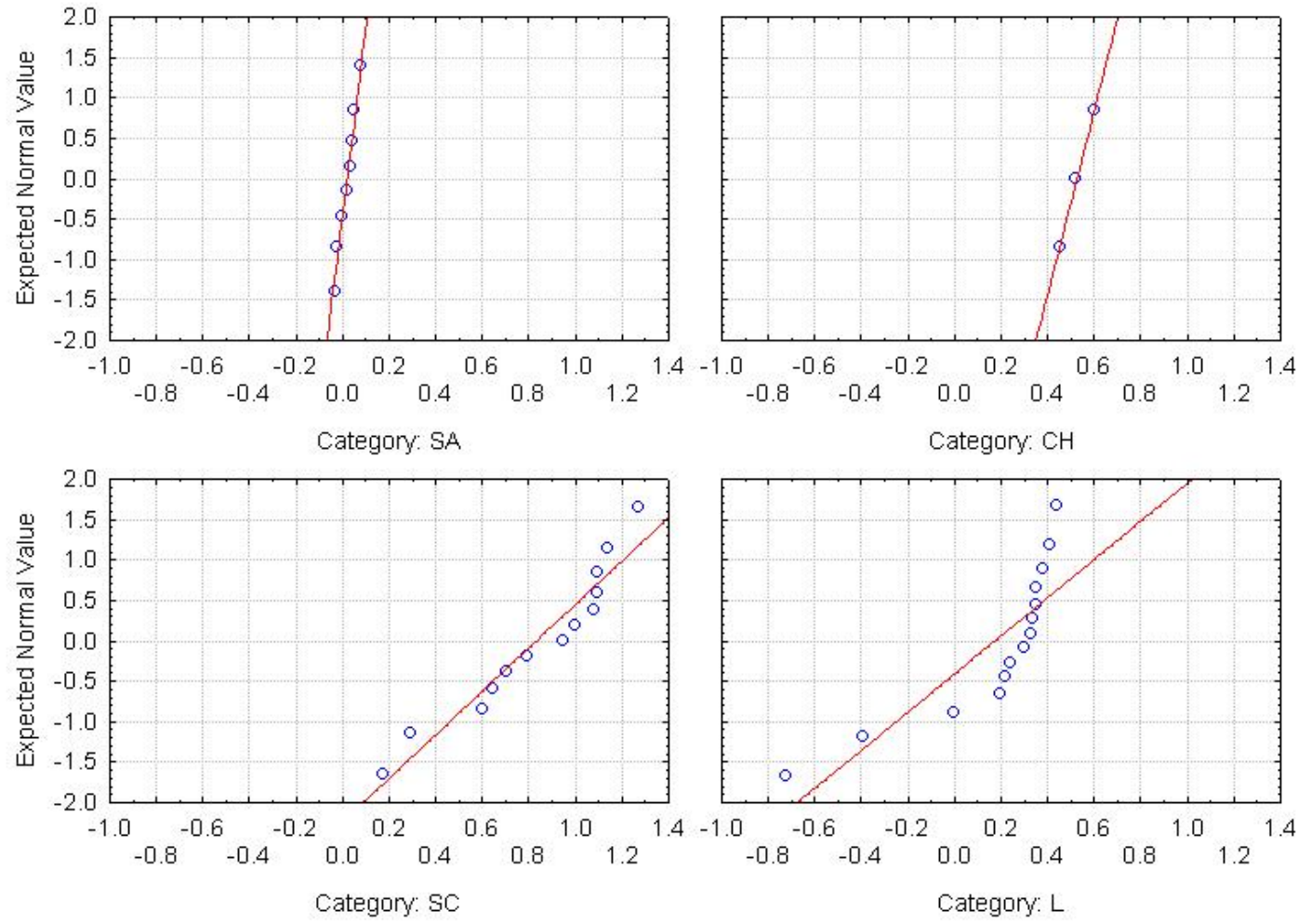
Categorized Probability Plot: AL2O3
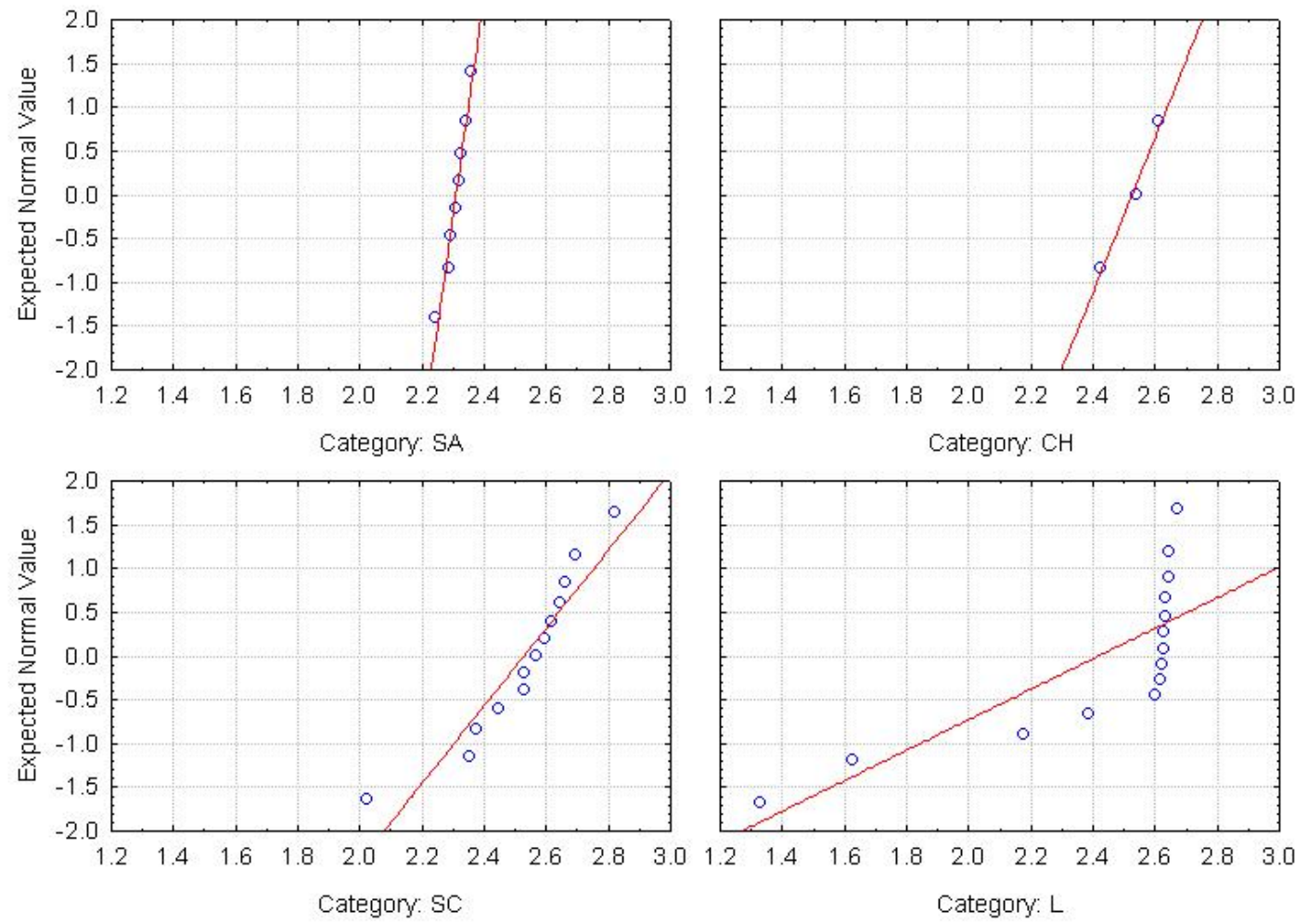

Categorized Probability Plot: FEO
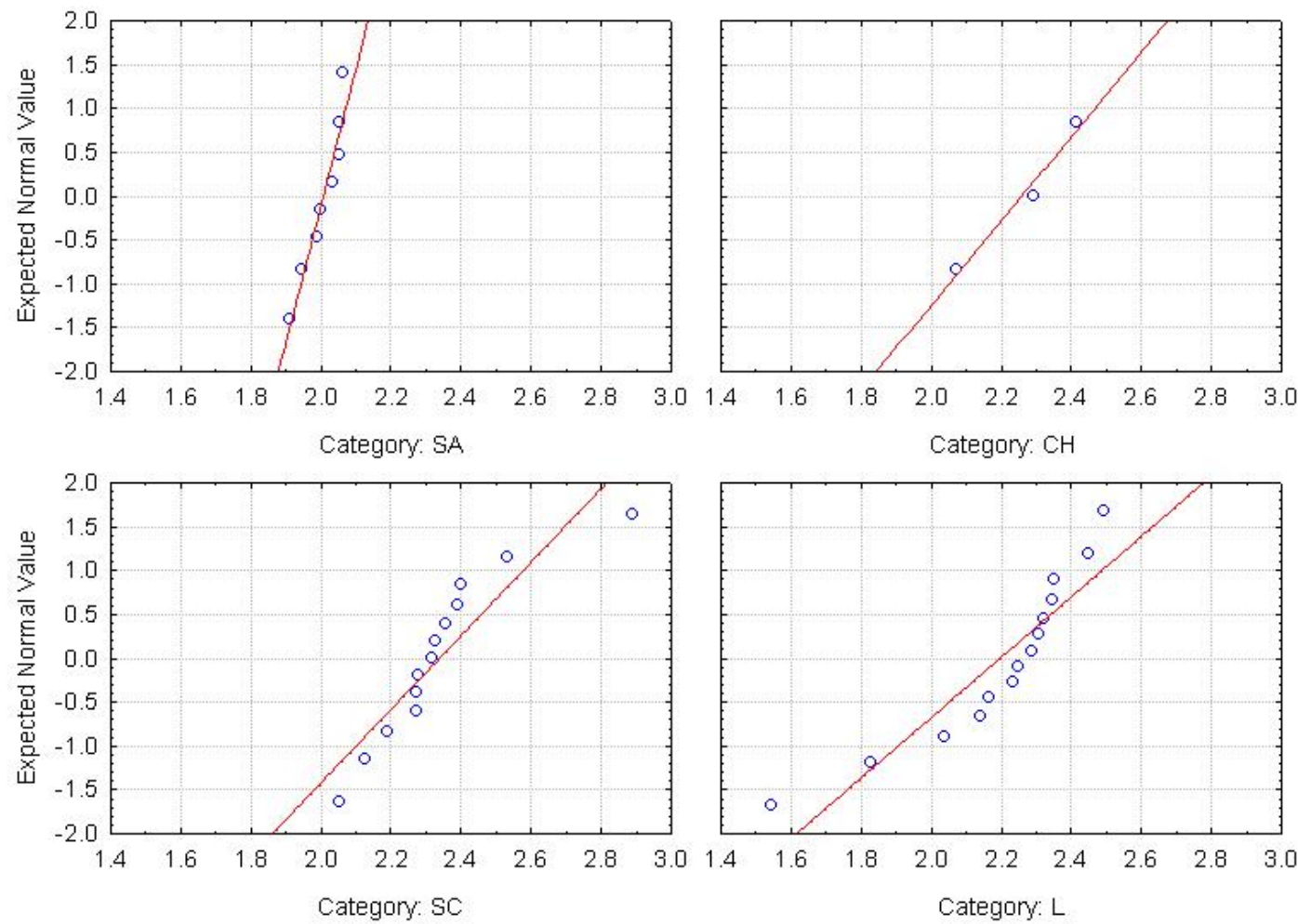
Categorized Probability Plot: MNO
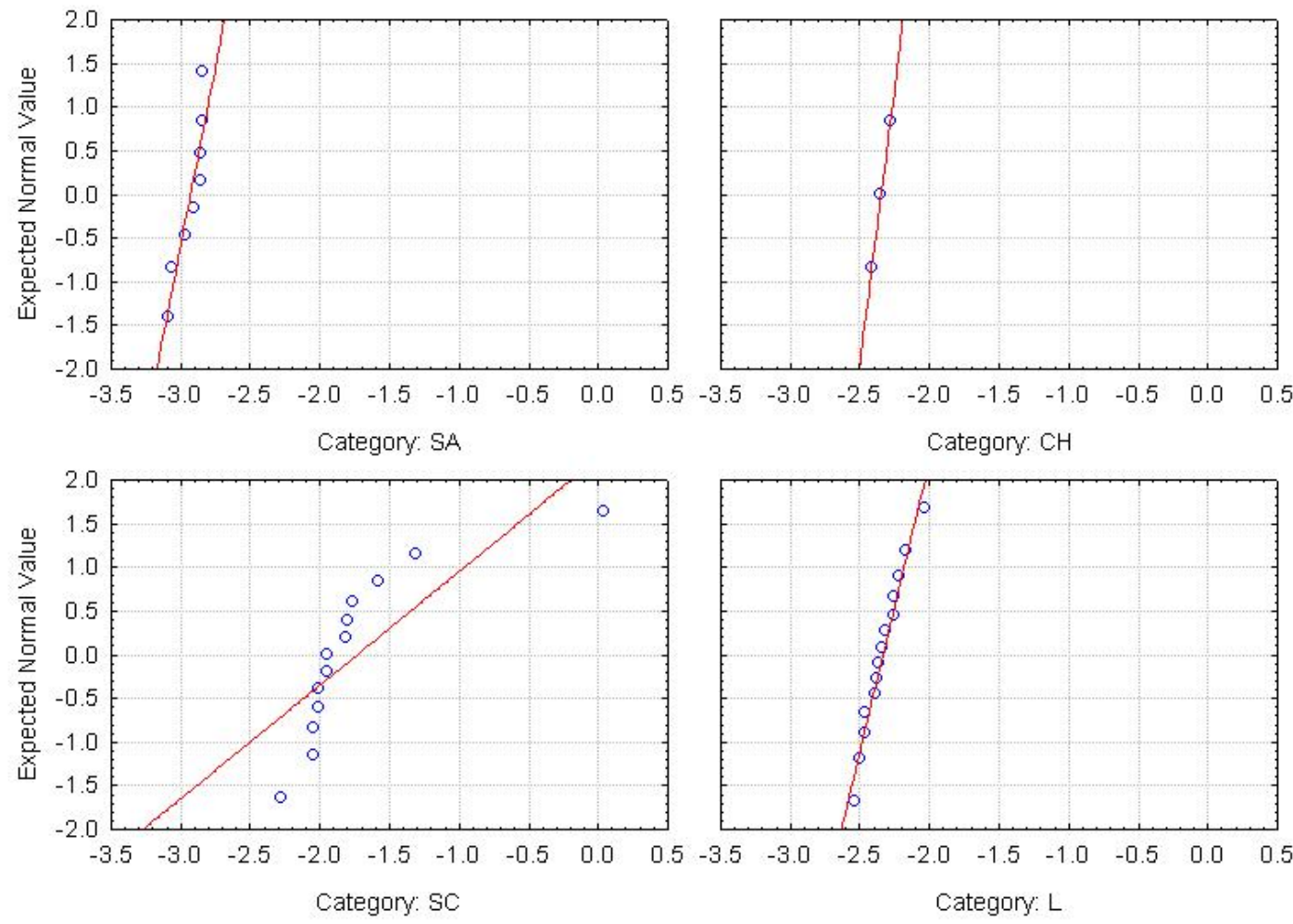

Categorized Probability Plot: MGO
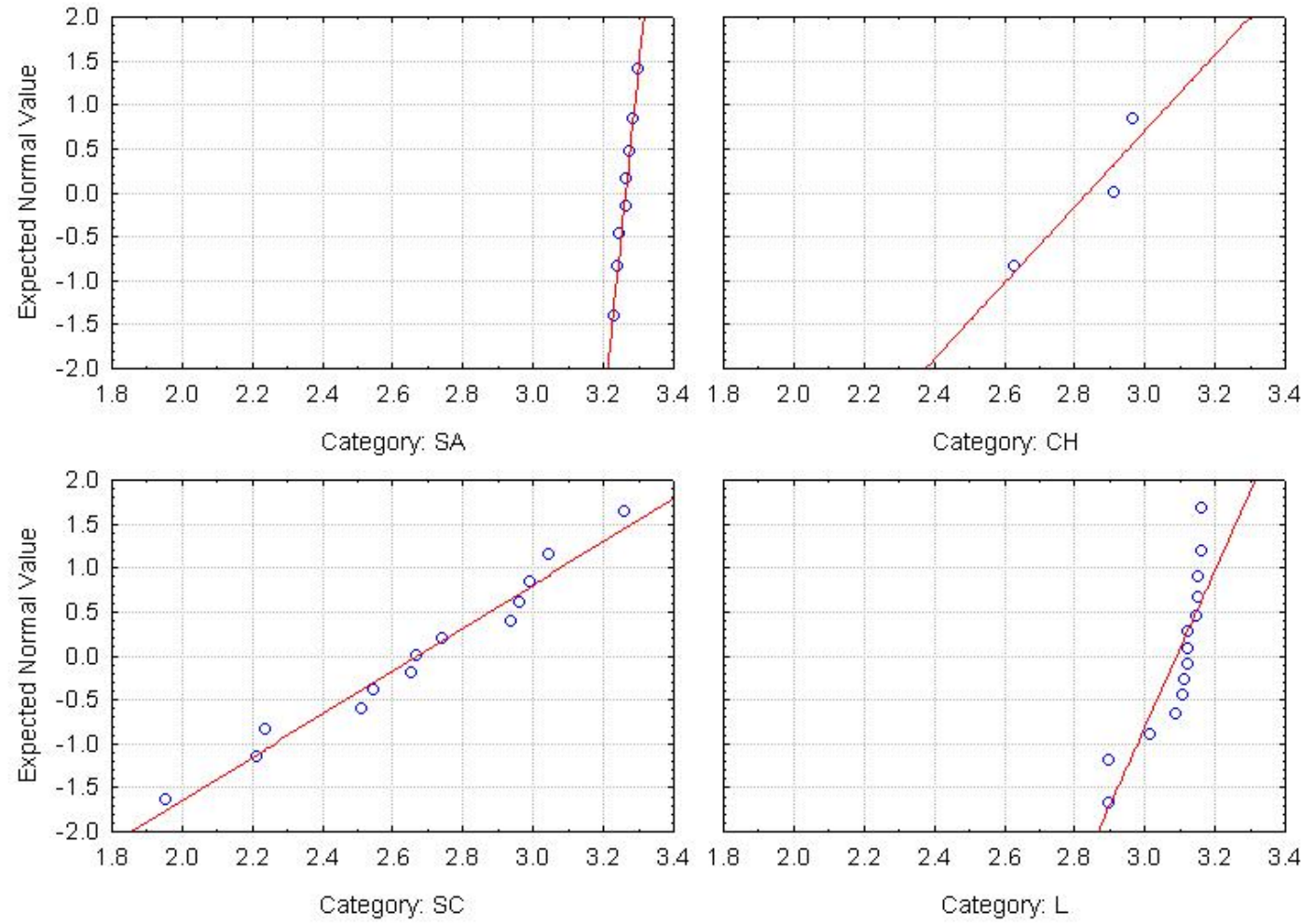
Categorized Probability Plot: CAO
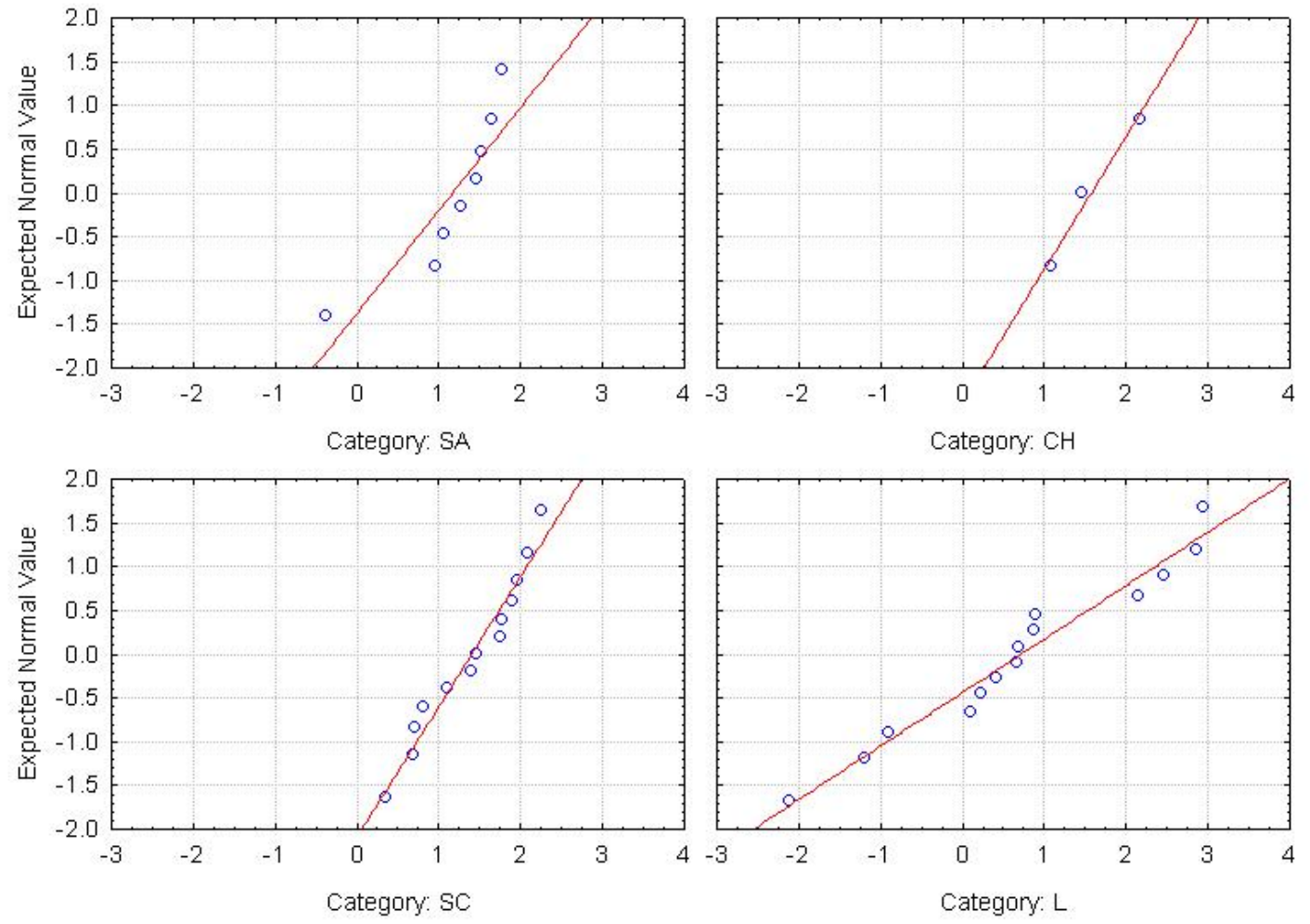

Categorized Probability Plot: NA2O
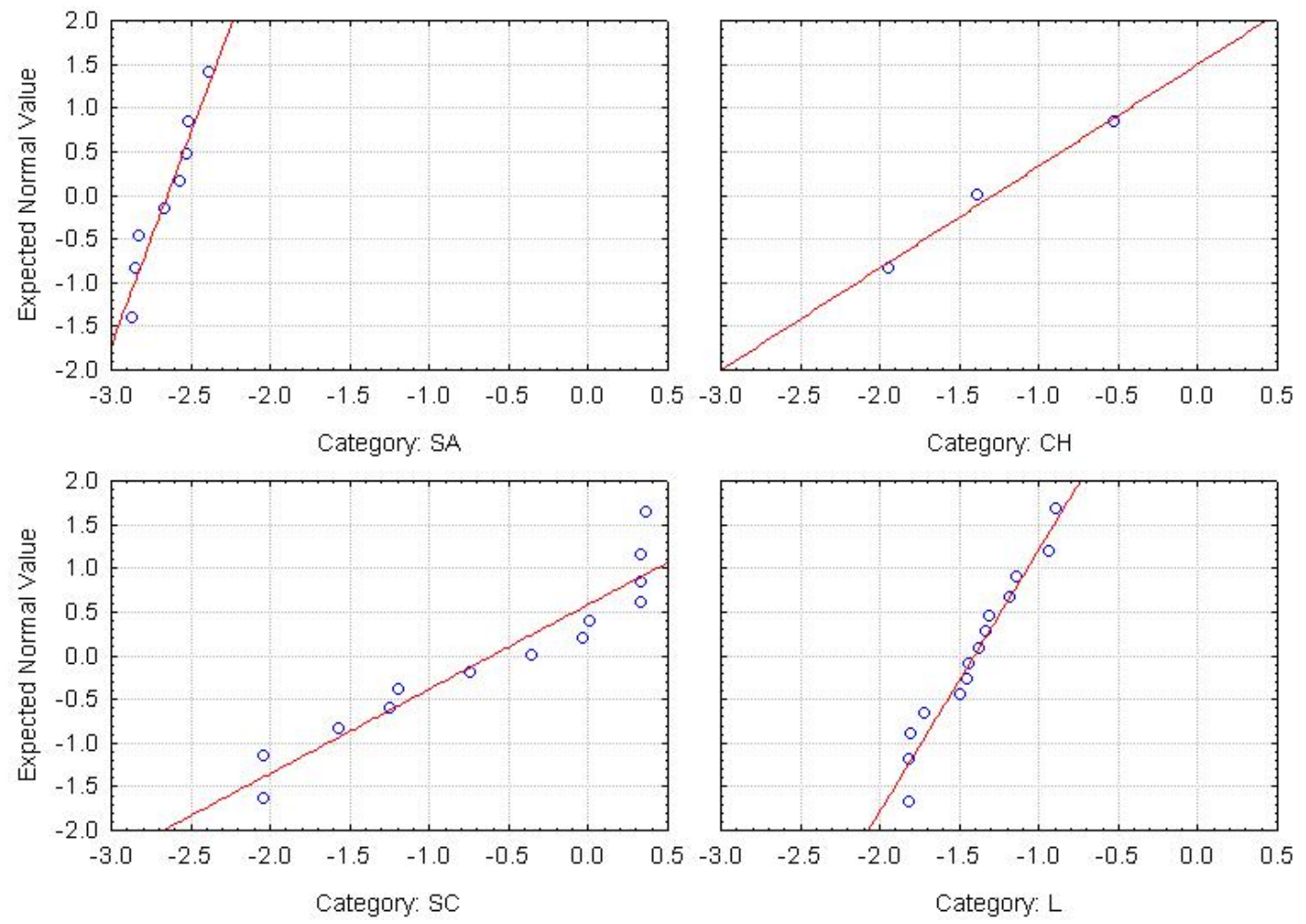
Categorized Probability Plot: $K 2 \mathrm{O}$
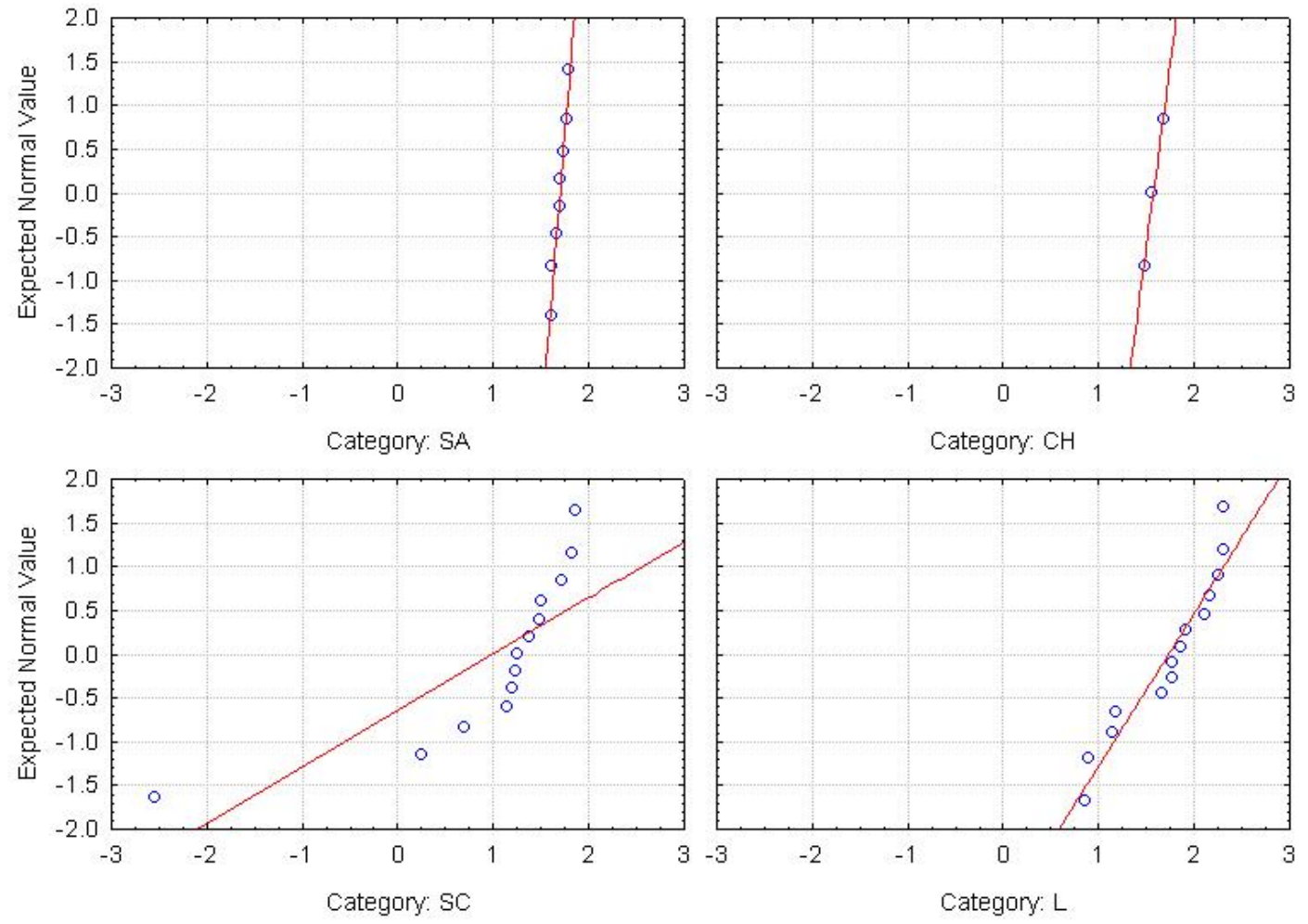

Categorized Probability Plot: BA
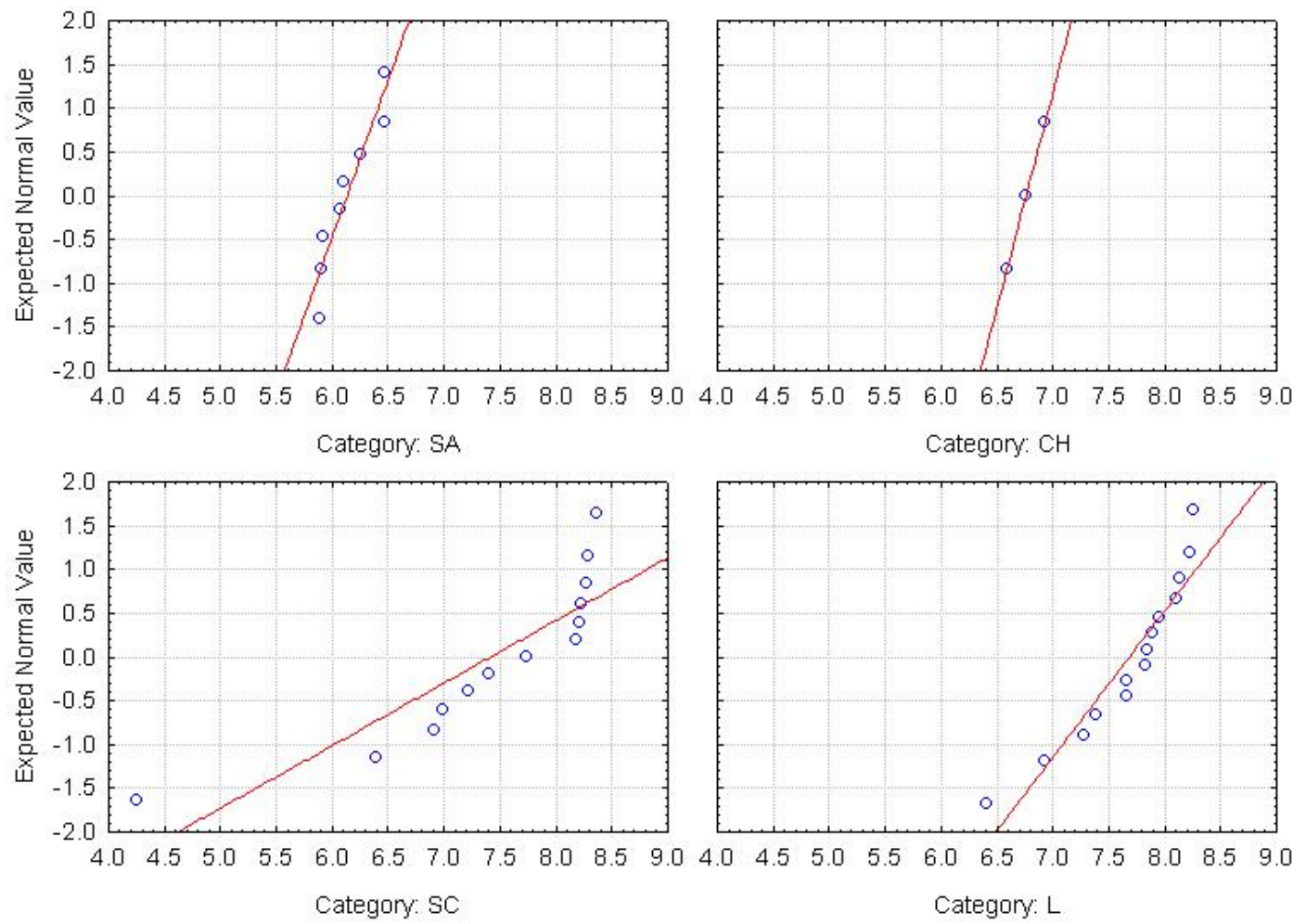
Categorized Probability Plot: CE
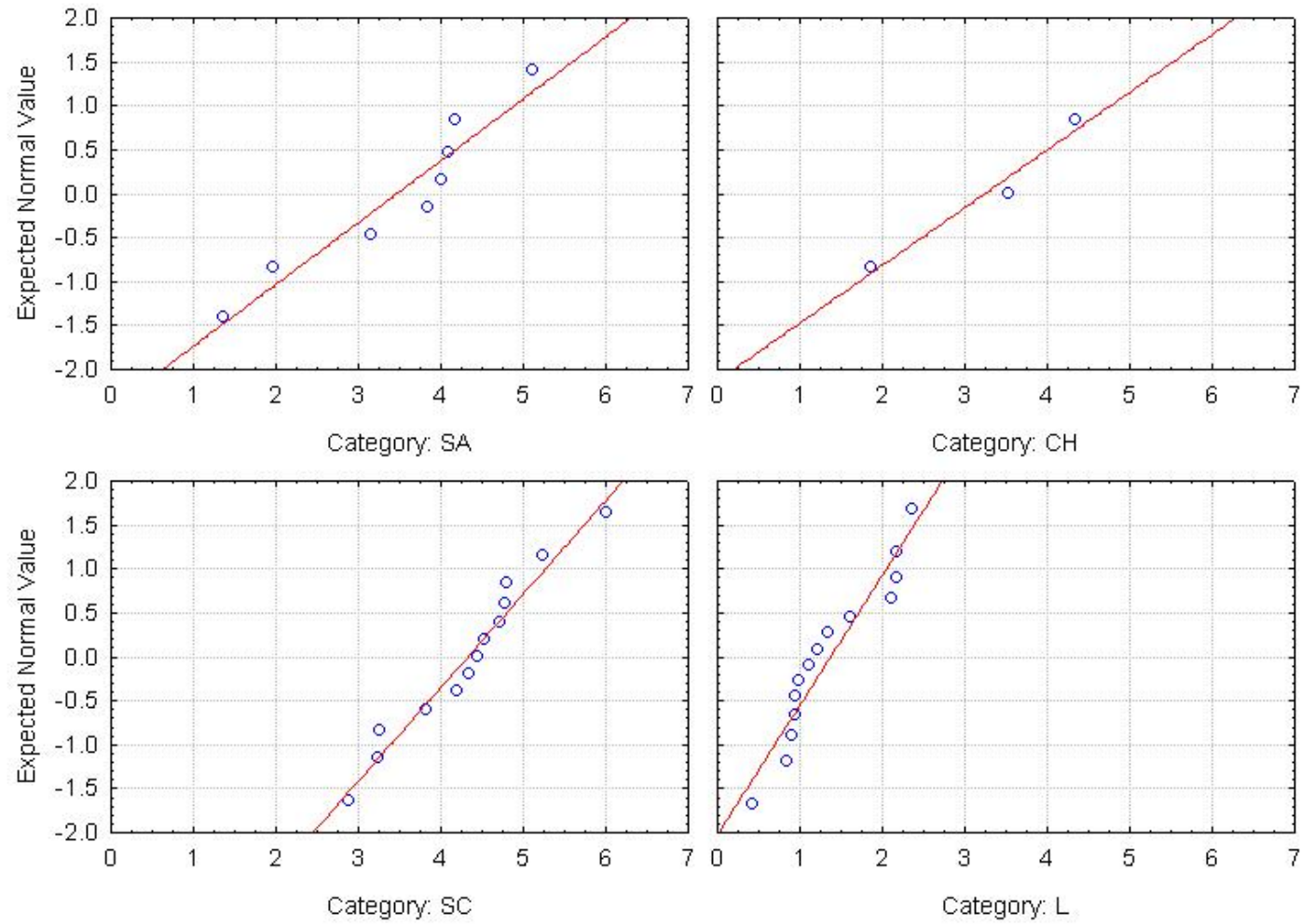

Categorized Probability Plot: CO
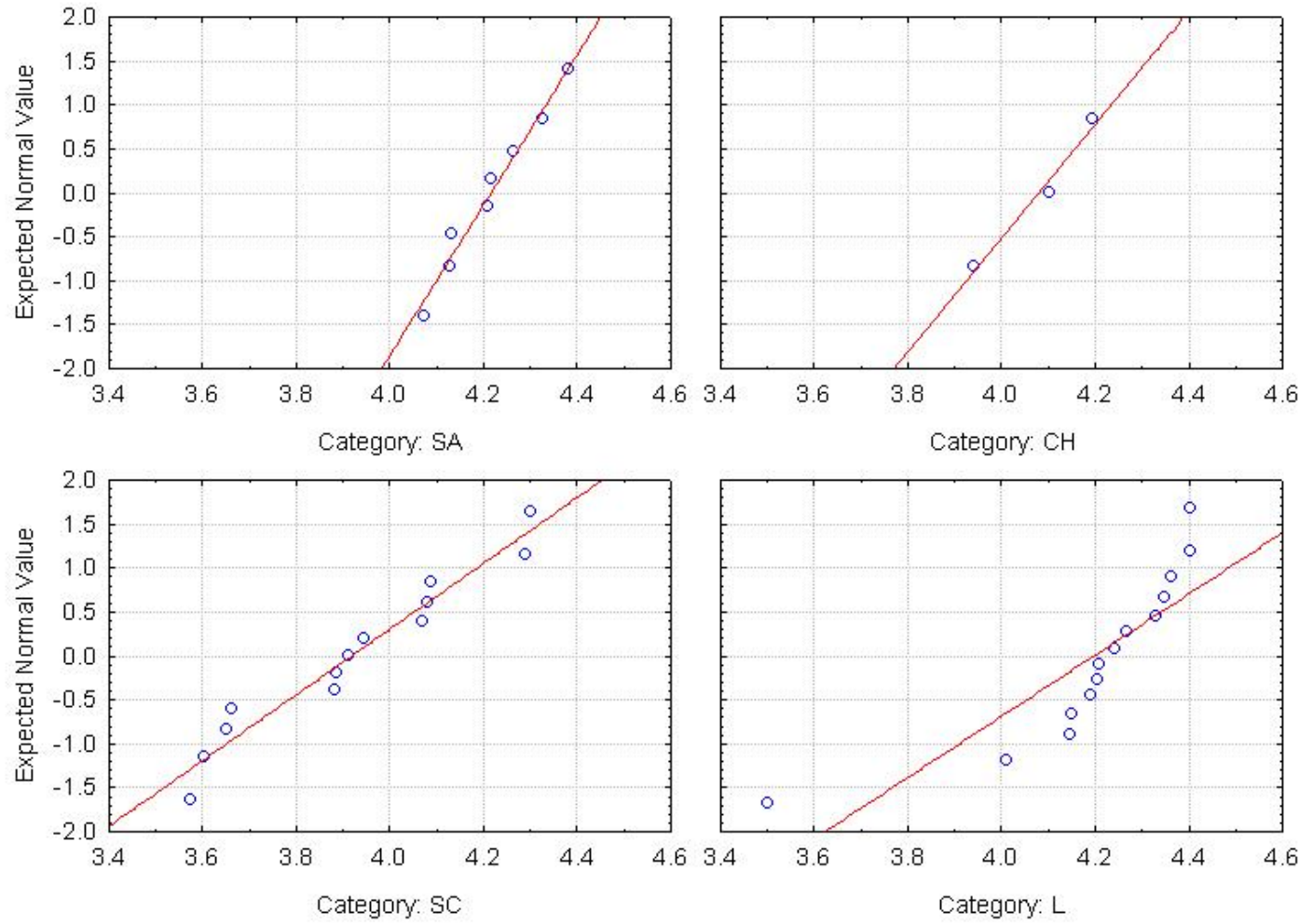
Categorized Probability Plot: $\mathrm{CR}$
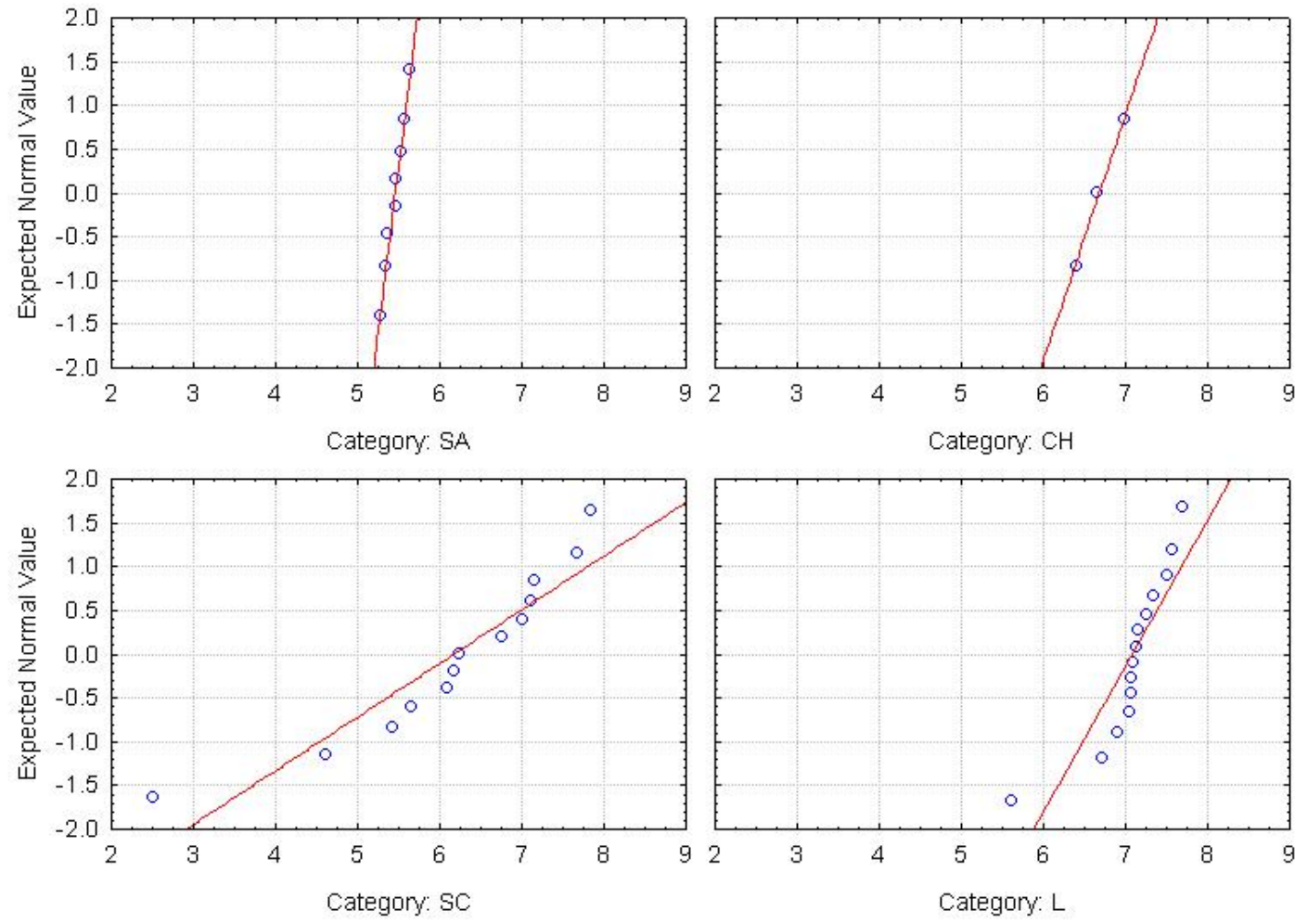

Categorized Probability Plot: CS
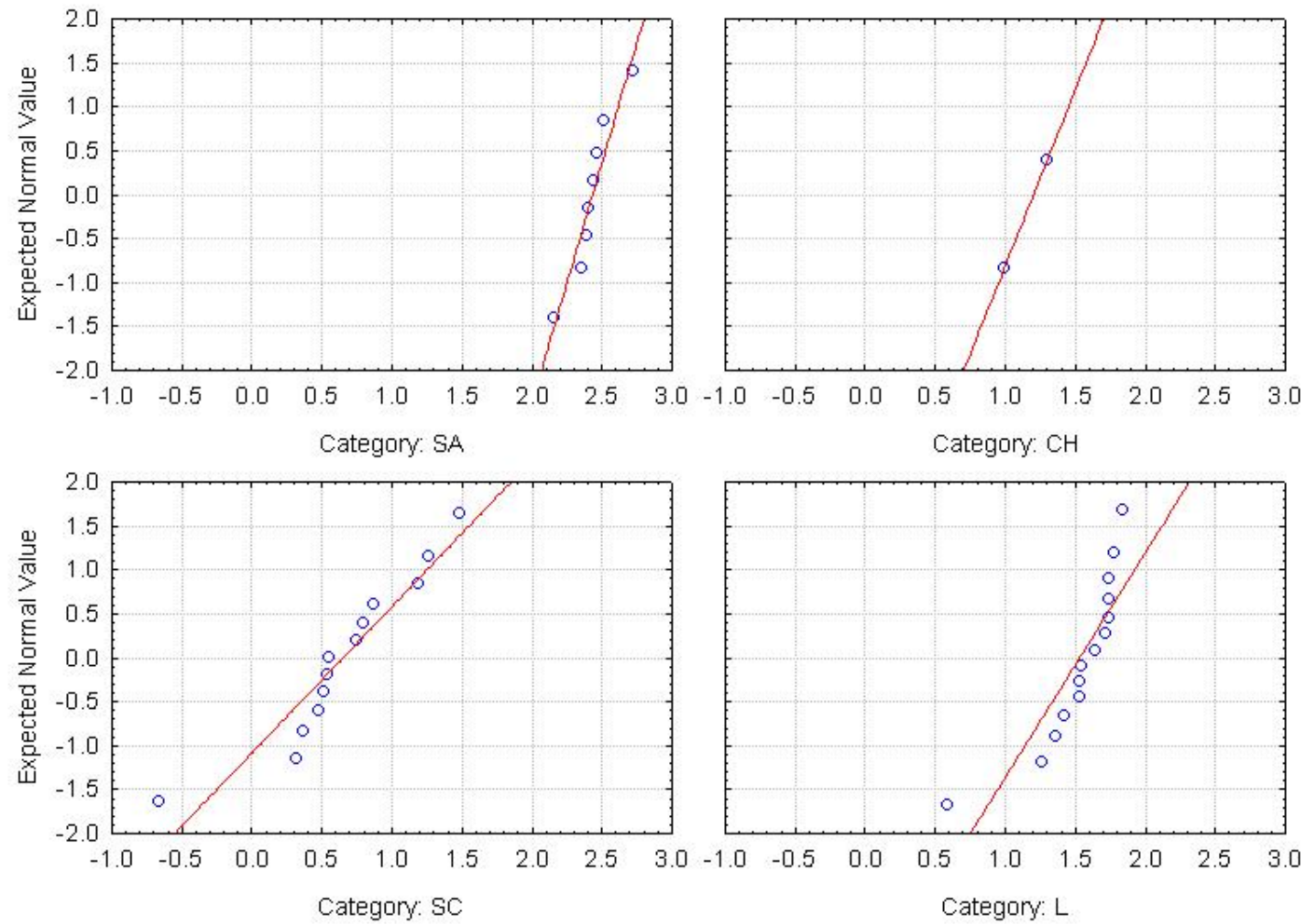
Categorized Probability Plot: CU
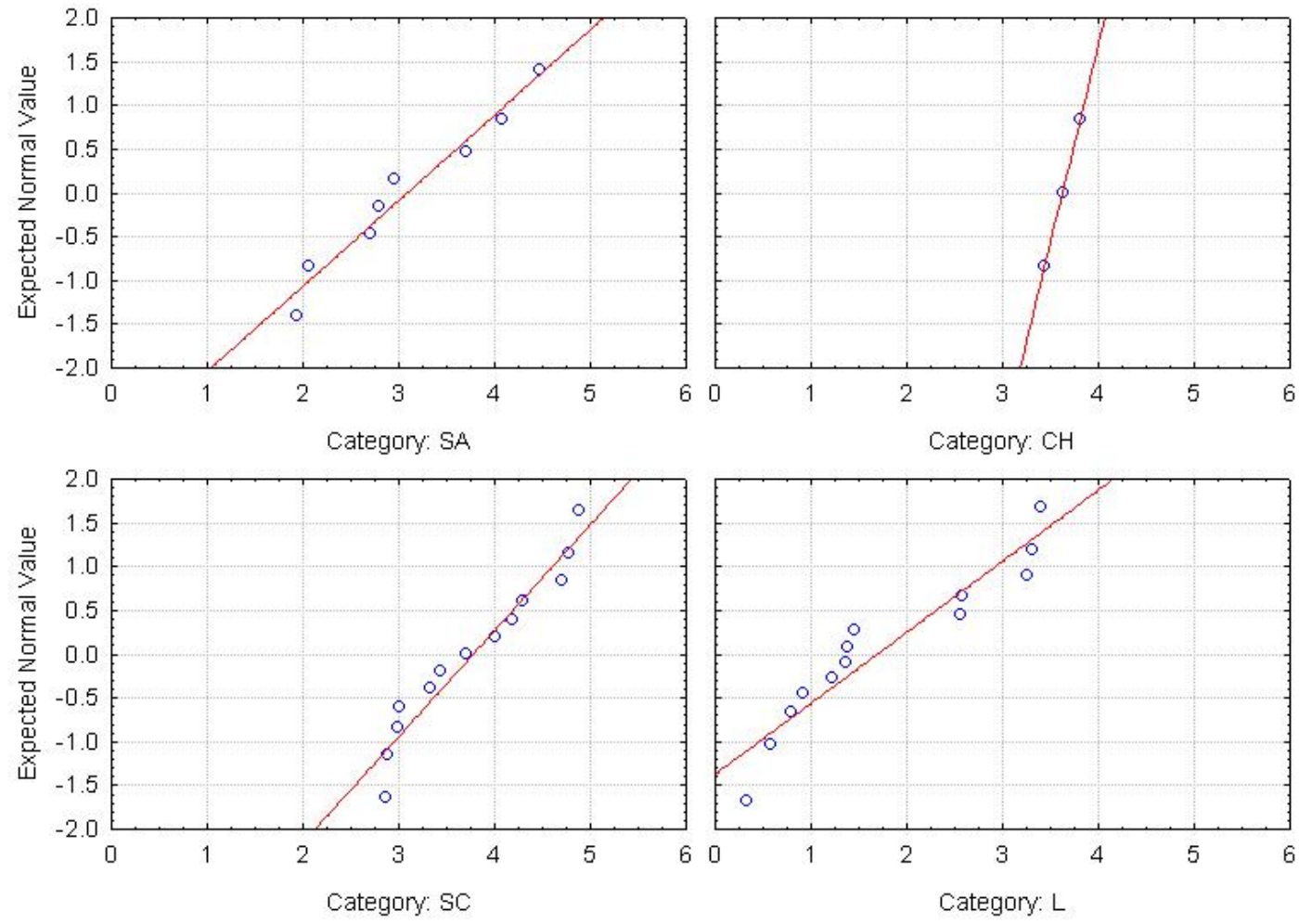

Categorized Probability Plot: GA
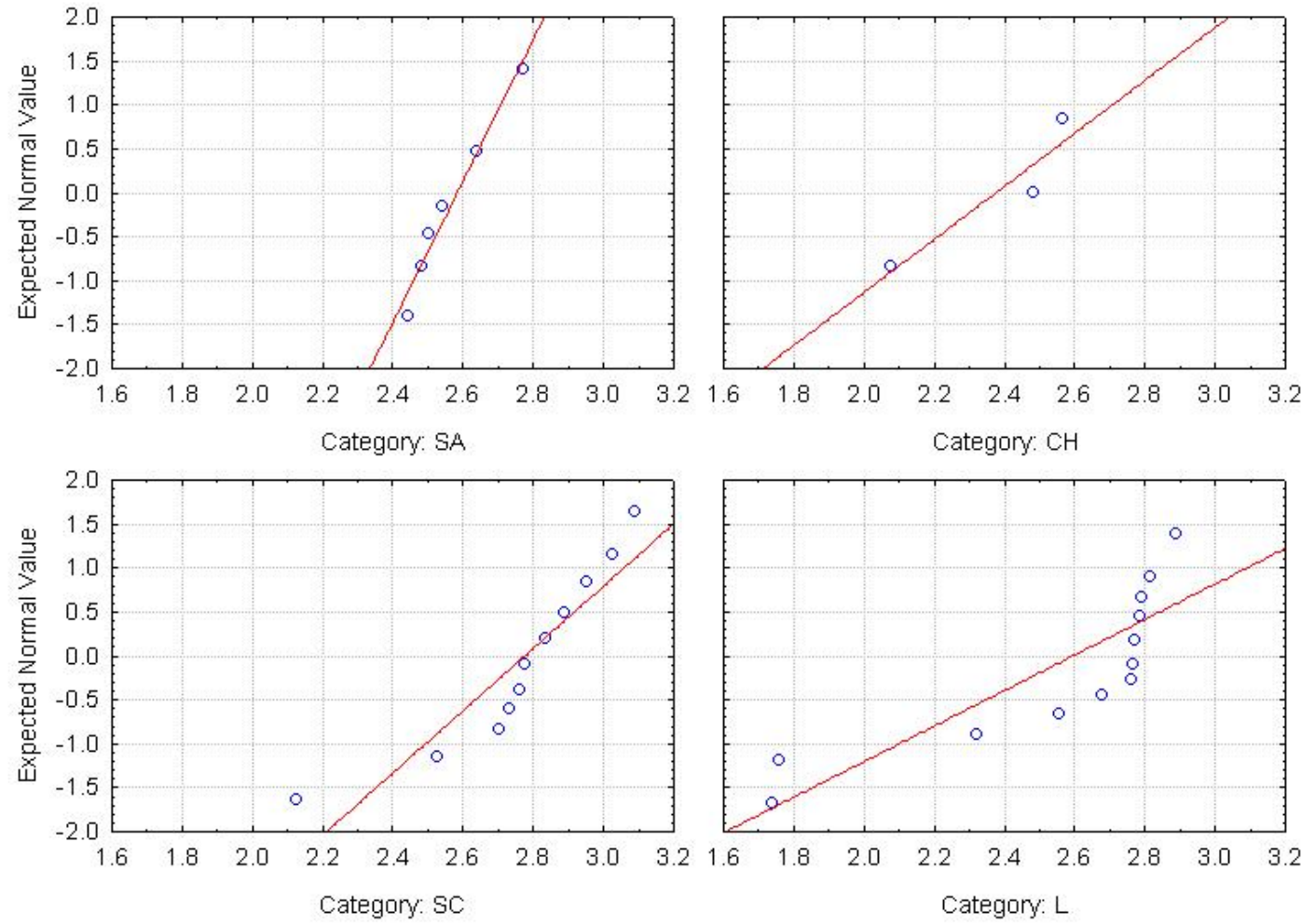
Categorized Probability Plot: LA
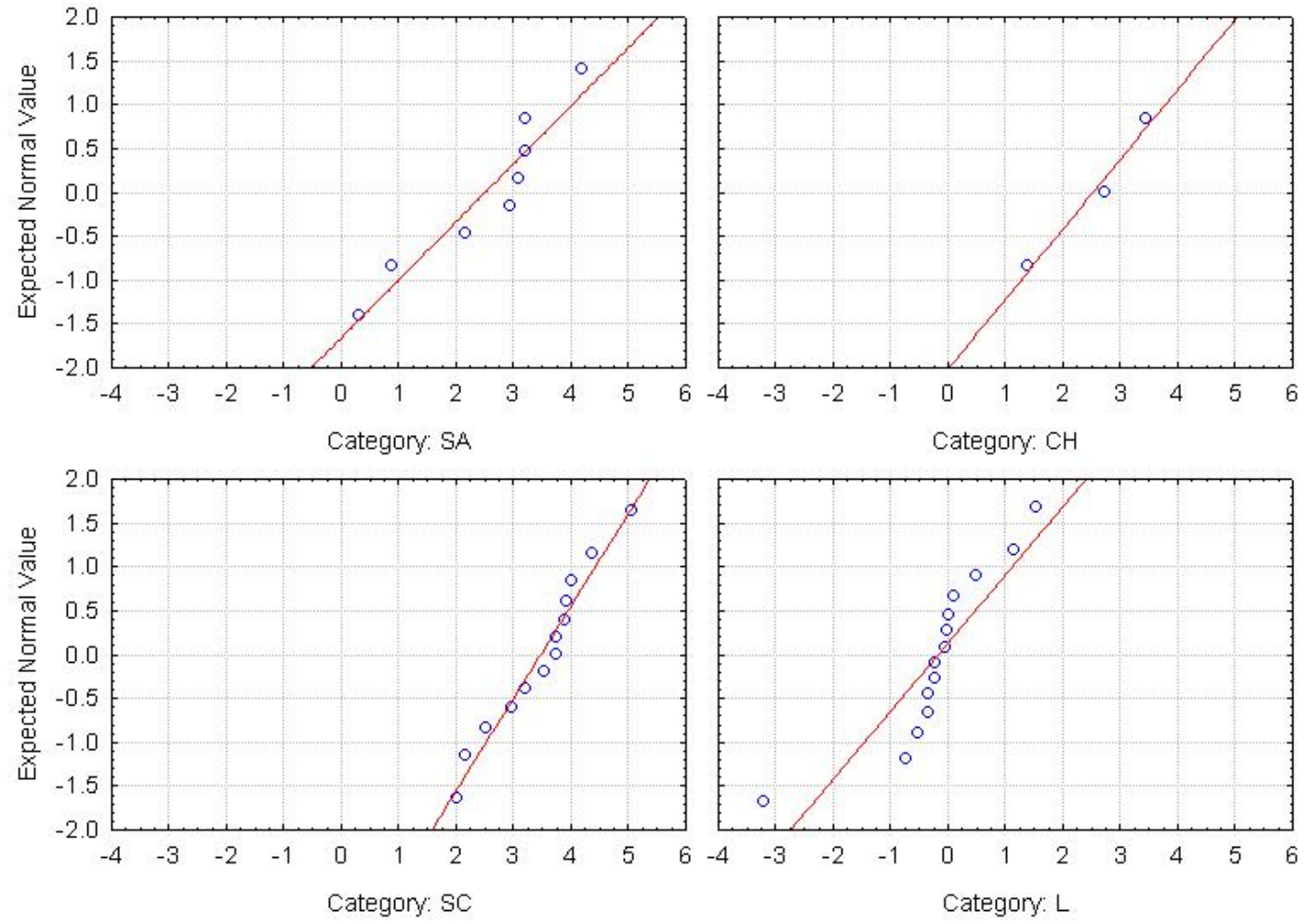

Categorized Probability Plot: NI
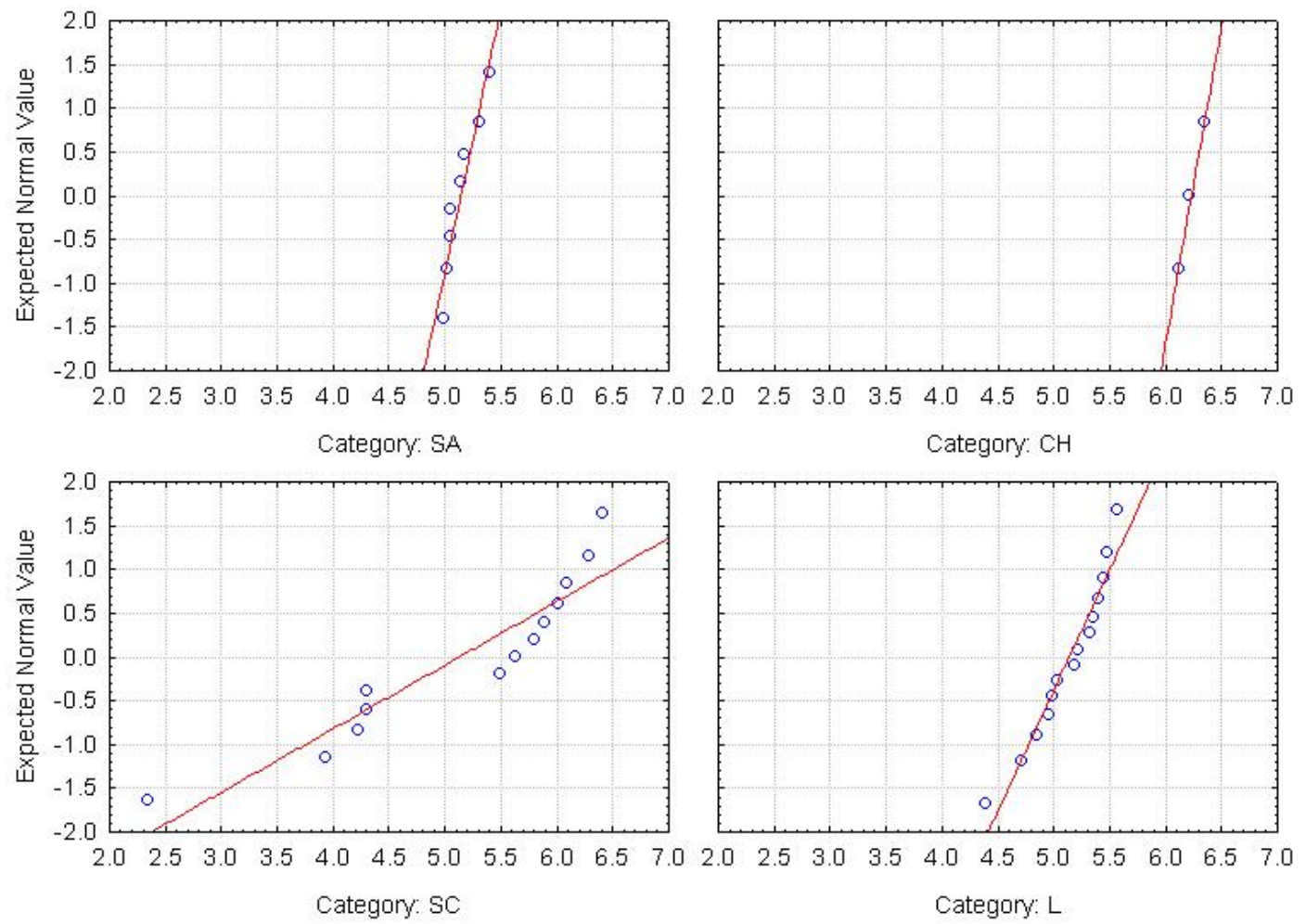
Categorized Probability Plot: RB
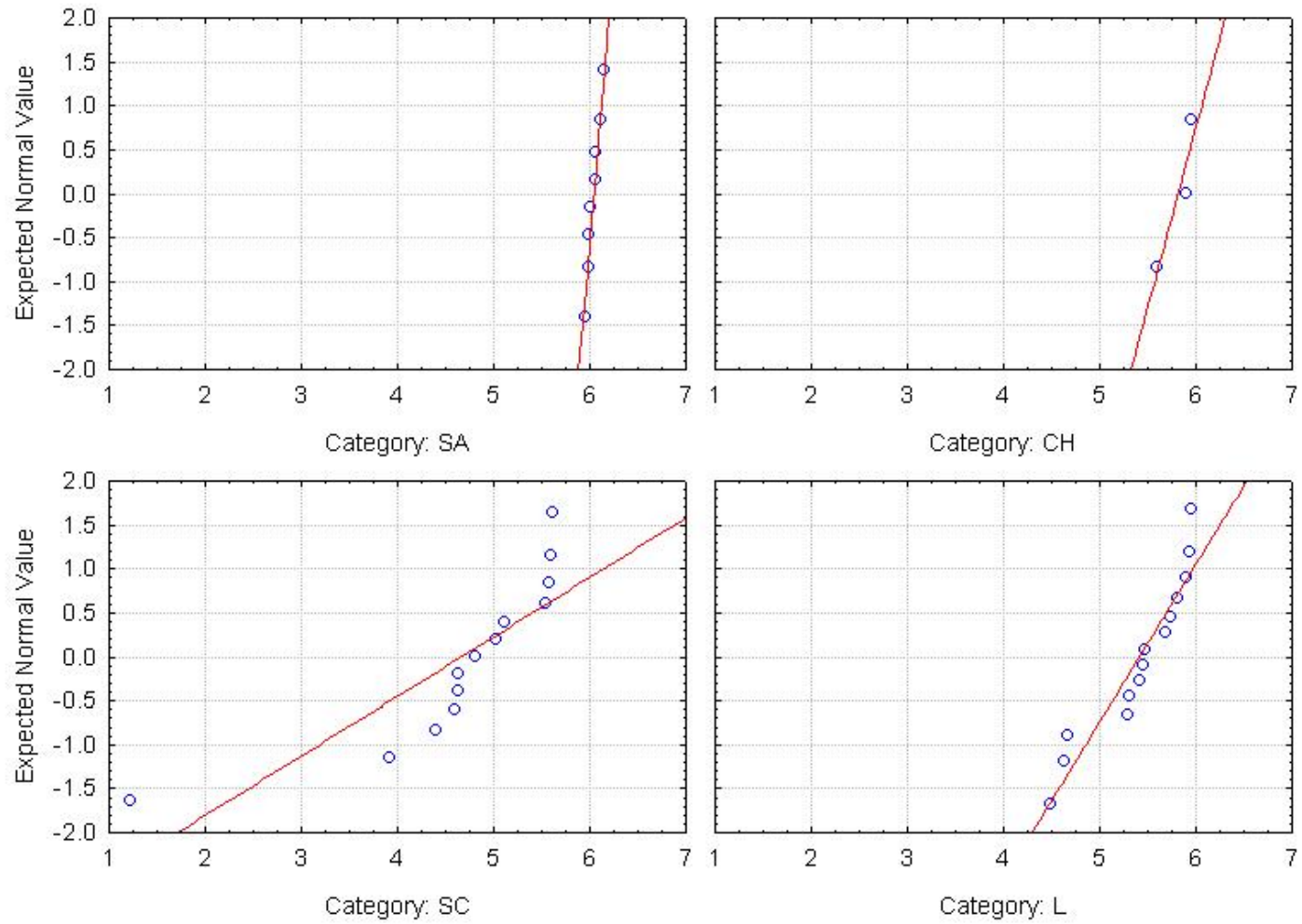

Categorized Probability Plot: SC
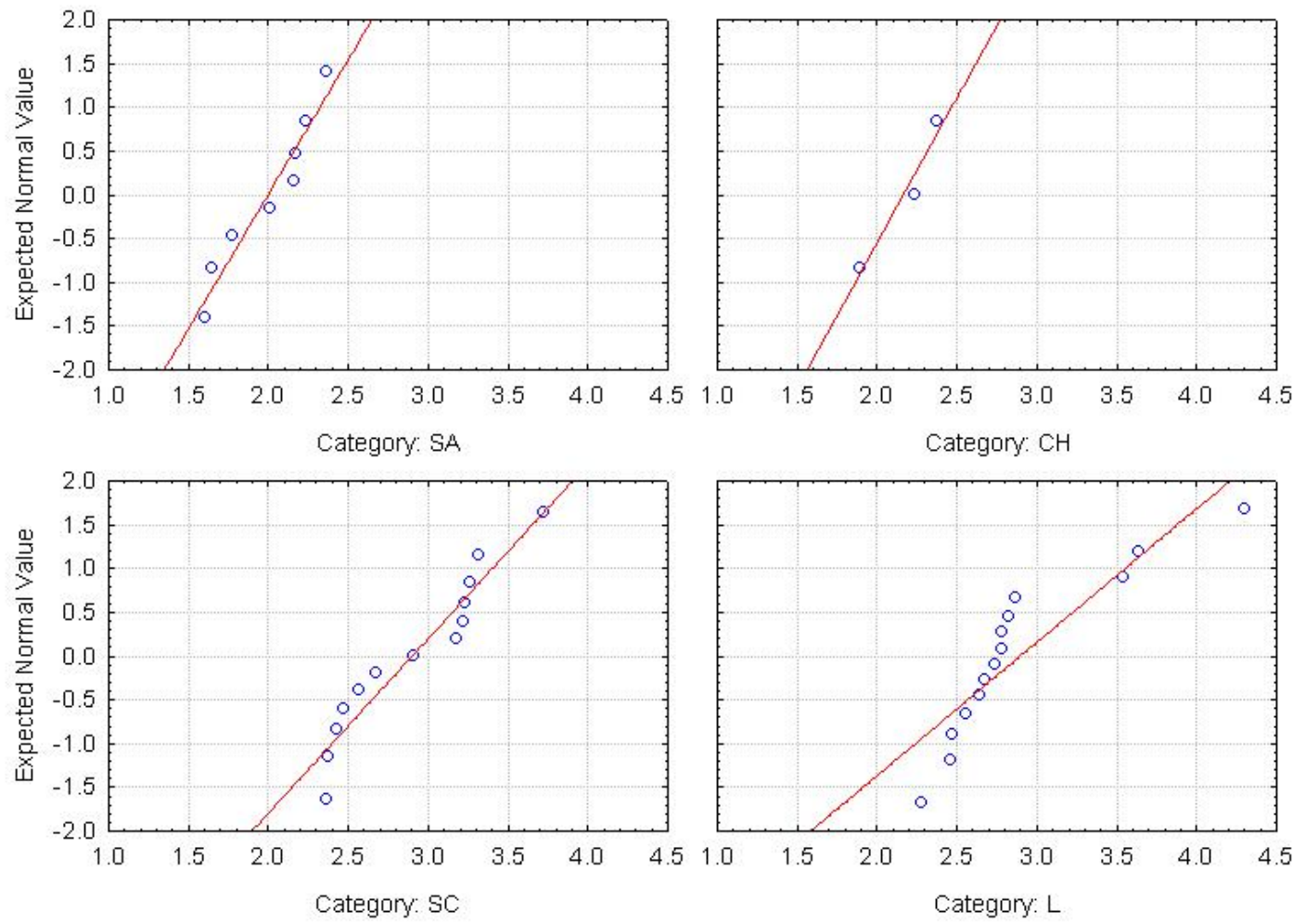
Categorized Probability Plot: SM
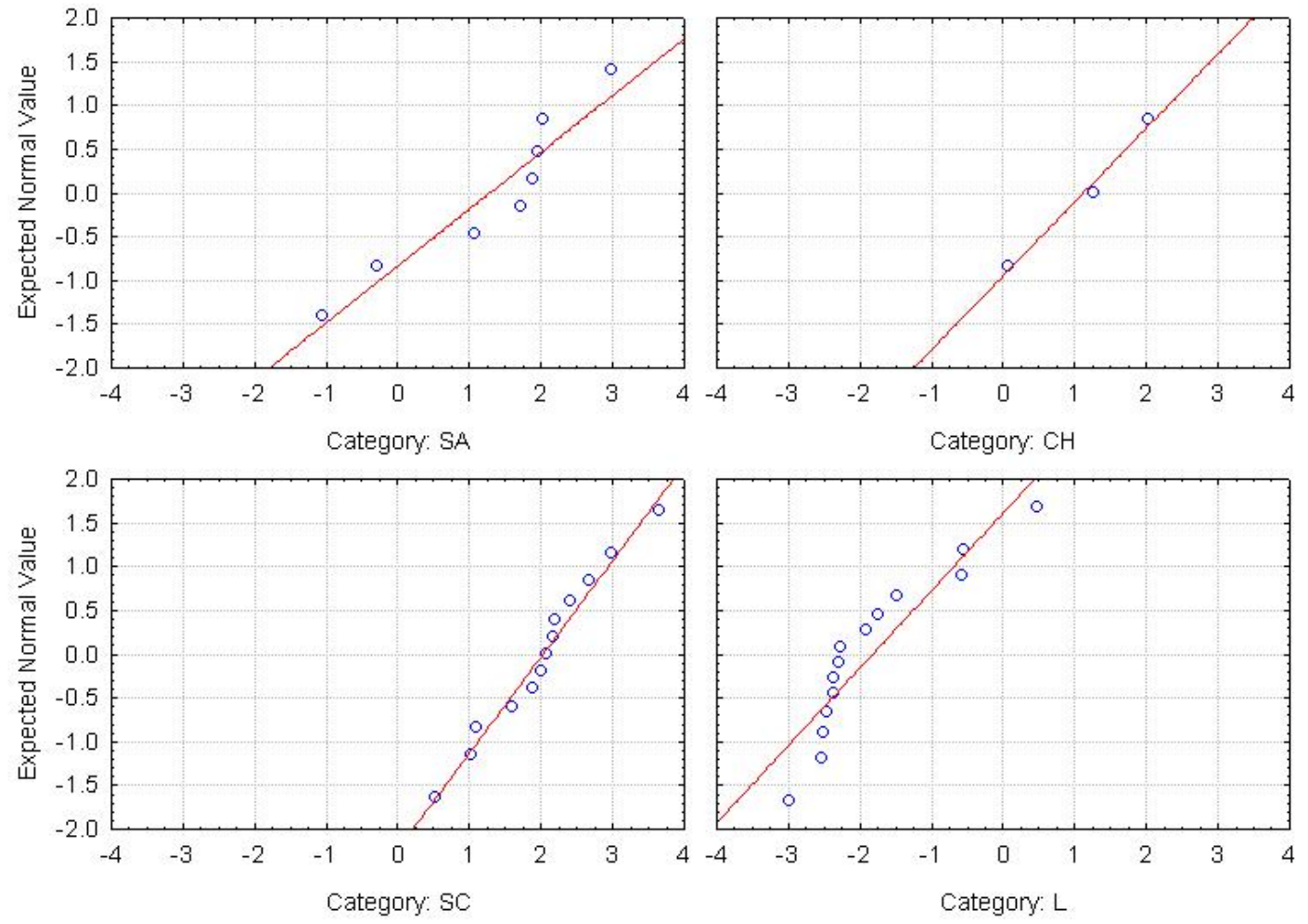

Categorized Probability Plot: SR
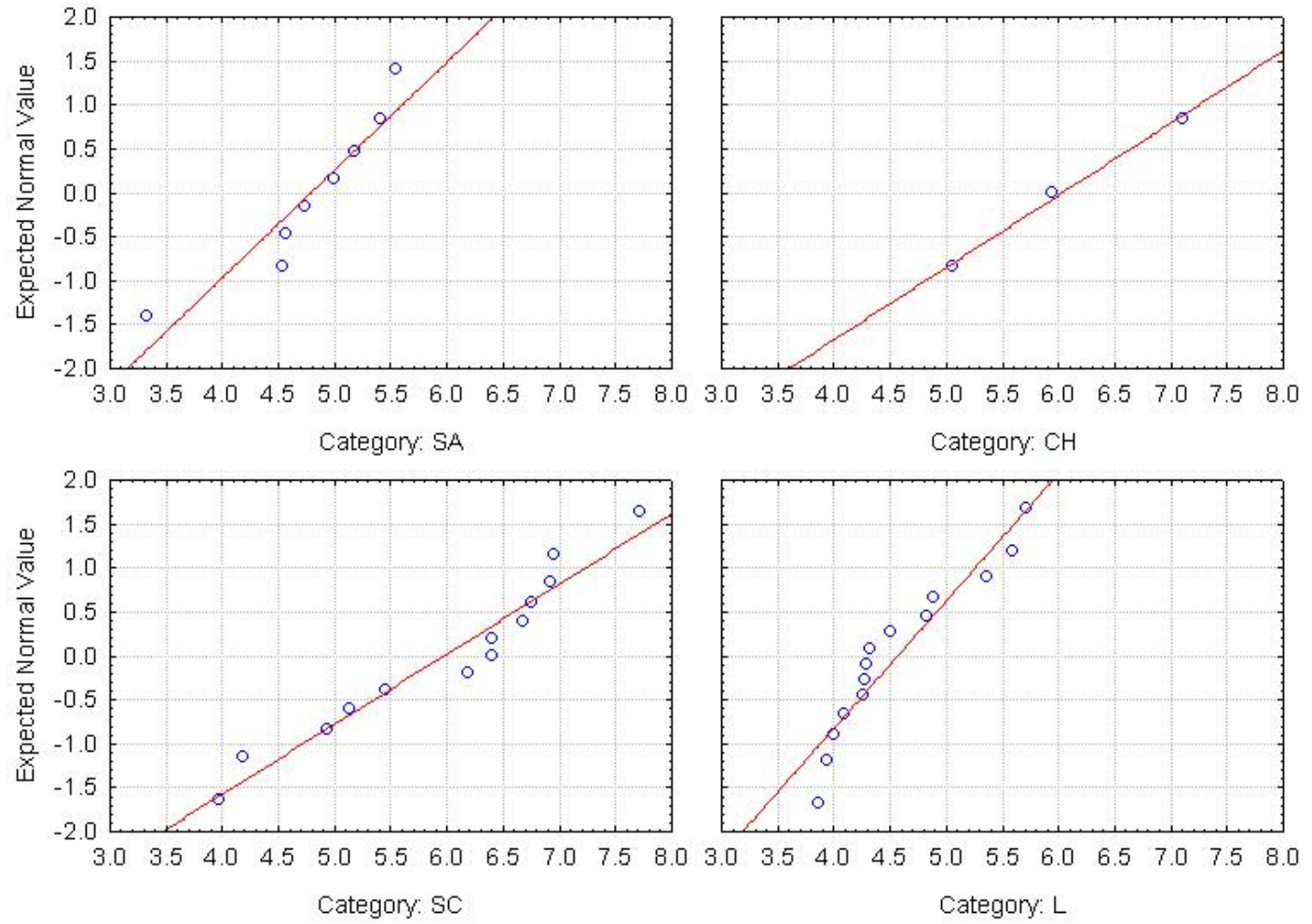
Categorized Probability Plot: V
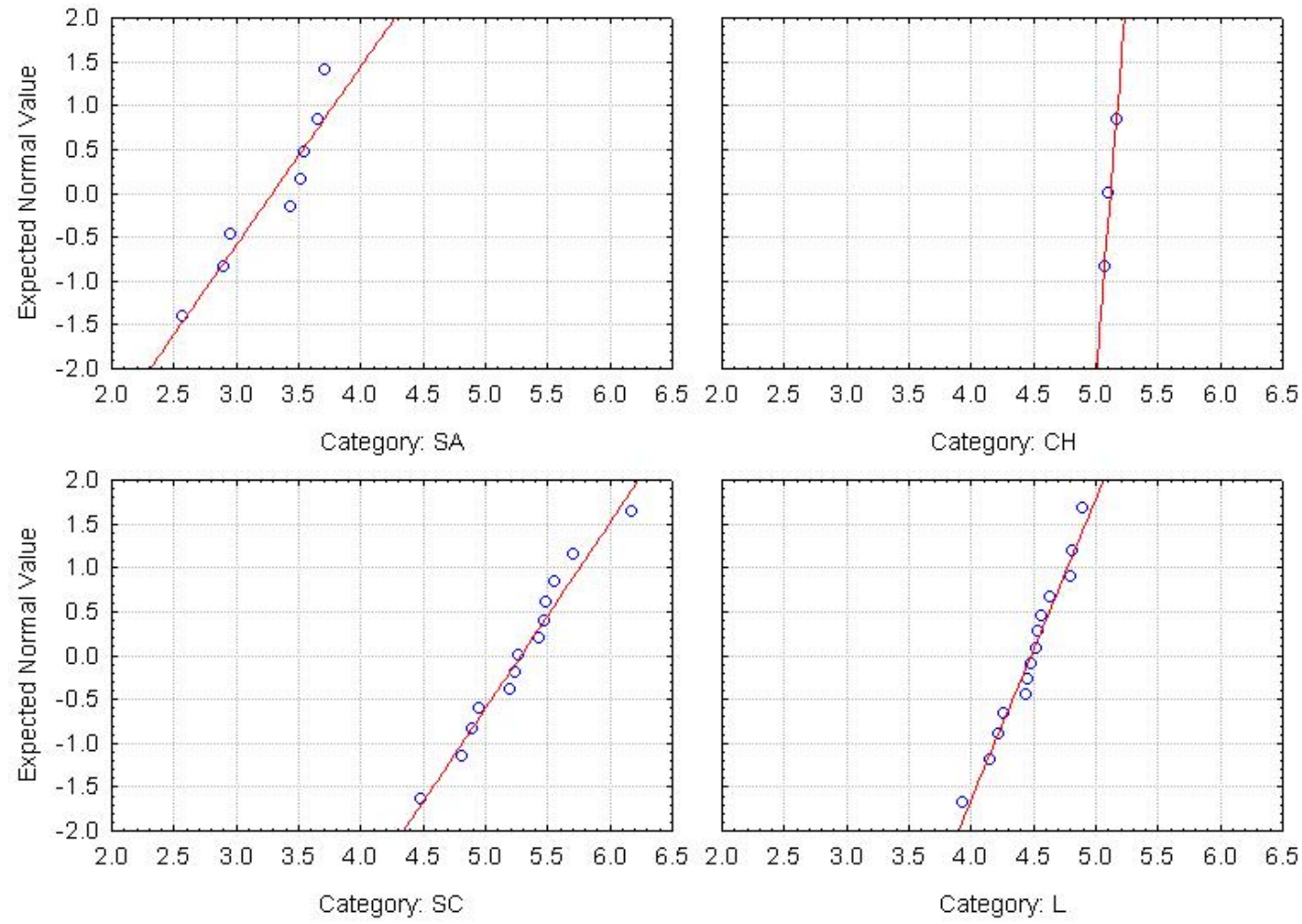

Categorized Probability Plot: ZN
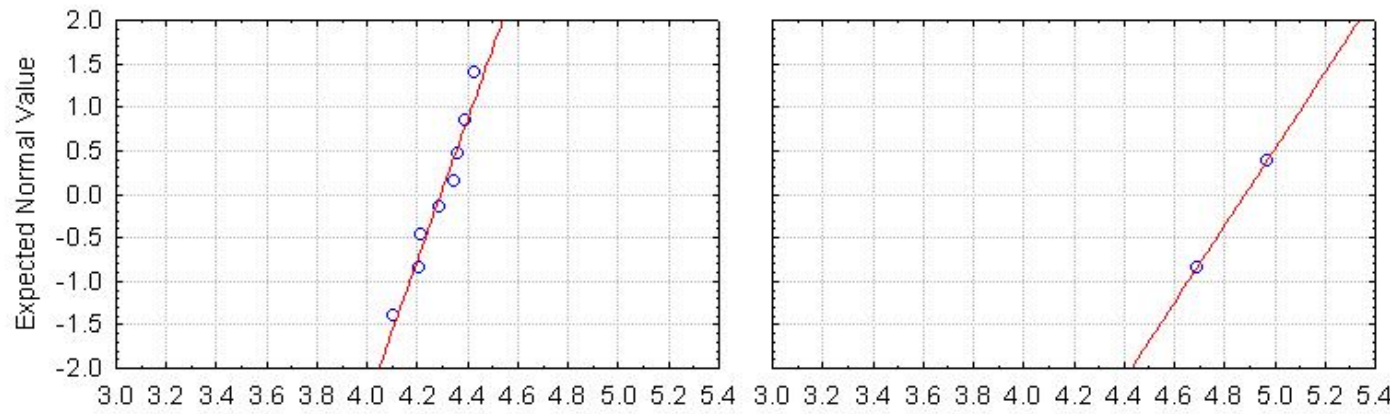

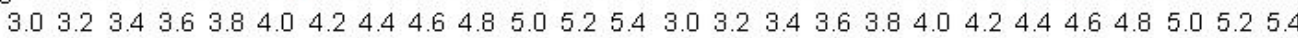
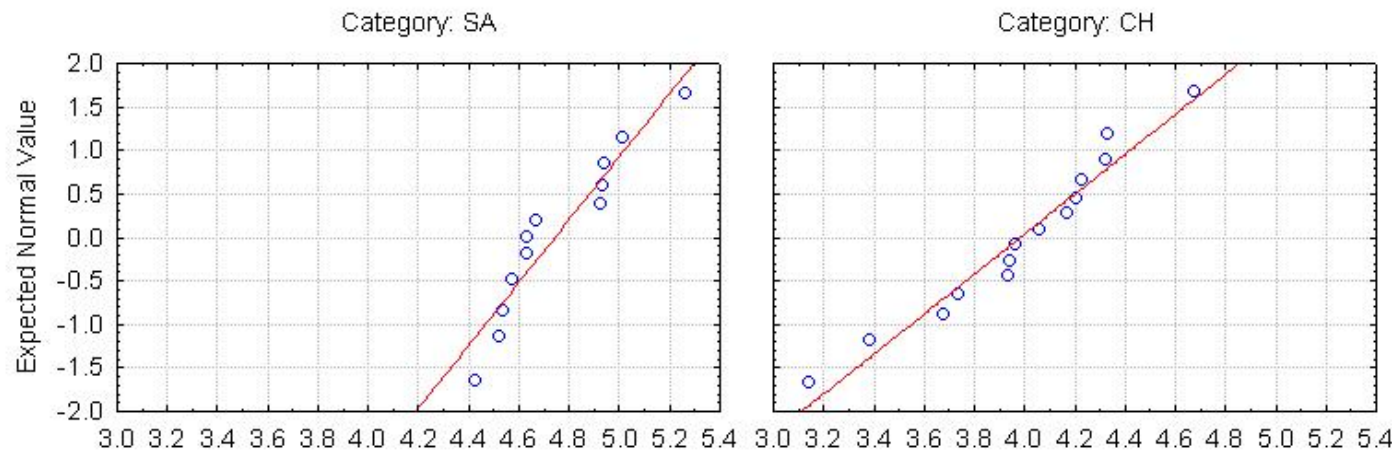

Category: SC

Category. L 
Appendix B

Analytical Data for Duplicates and Blind Standards 
Neutron Activation Analysis Data for Duplicates and Blind Standards

\begin{tabular}{|c|c|c|c|c|c|c|c|c|c|c|c|c|}
\hline Sample & $\mathrm{FeO} \%$ & $\mathrm{Na2O} \%$ & Sc ppm & Cr ppm & Co ppm & Ni ppm & Rb ppm & Cs ppm & Sr ppm & Ba ppm & La ppm & Ce ppm \\
\hline $\mathrm{SC}-7$ & 11.5 & 0.12 & 14.5 & 865 & 58.5 & 295 & 47 & 1.37 & 210 & 600 & 24.7 & 66.8 \\
\hline SC-13 (SC7dup) & 11.6 & 0.11 & 14.5 & 864 & 58.6 & 290 & 49 & 1.36 & 270 & 570 & 24.7 & 69.9 \\
\hline PVC5 & 8.32 & 0.37 & 10.7 & 1220 & 51.6 & 545 & 148 & 2.38 & 320 & 3820 & 7.6 & 17.8 \\
\hline 12A (PVC5 dup) & 8.57 & 0.35 & 11.9 & 1130 & 57.9 & 370 & 142 & 2.26 & 30 & 3390 & 7.0 & 16.6 \\
\hline NIST $1633-b$ values & 10.01 & 0.37 & 41 & 198.2 & 50 & 120.6 & 140 & 11 & 1041 & 709 & 94 & 190 \\
\hline $\mathrm{SC}-12(1633 \mathrm{~b})$ & 10.3 & 0.28 & 34.7 & 193 & 41.3 & 113 & 140 & 11.0 & 1070 & 660 & 84.3 & 198 \\
\hline $13 \mathrm{~A}(1633 \mathrm{~b})$ & 10.6 & 0.29 & 42.5 & 209 & 49.5 & 8 & 145 & 10.8 & 1130 & 725 & 84.7 & 196 \\
\hline average & 10.5 & 0.3 & 38.6 & 201 & 45.4 & 60.5 & 142.5 & 10.9 & 1100 & 693 & 84.5 & 197 \\
\hline dev from accept $\%$ & 4.40 & -24.2 & -5.85 & 1.41 & -9.20 & -49.8 & 1.79 & -0.91 & 5.67 & -2.33 & -10.11 & 3.68 \\
\hline USGS SDC-1 values & $\mathrm{n} / \mathrm{a}$ & 2.05 & 17 & 64 & 18 & 38 & 127 & 4 & 180 & 630 & 42 & 93 \\
\hline 14A(mica schist) & 6.53 & 2.03 & 15.8 & 66 & 18.5 & 5 & 119 & 3.21 & 180 & 625 & 41.7 & 95.1 \\
\hline SDC-1 (mica schist) & 6.70 & 2.03 & 13.3 & 65 & 17.3 & 19 & 133 & 3.43 & 250 & 630 & 39.7 & 100 \\
\hline average & 6.615 & 2.03 & 14.6 & 65.8 & 17.9 & 12.1 & 126 & 3.32 & 215 & 628 & 40.7 & 97.6 \\
\hline dev from accept $\%$ & & -0.98 & -14.4 & 2.73 & -0.56 & -68.3 & -0.79 & -17.0 & 19.4 & -0.40 & -3.10 & 4.89 \\
\hline
\end{tabular}


Neutron Activation Analysis Data for Duplicates and Blind Standards

\begin{tabular}{|c|c|c|c|c|c|c|c|c|c|c|c|}
\hline Sample & Nd ppm & Sm ppm & Eu ppm & Tb ppm & Yb ppm & Lu ppm & Zr ppm & Hf ppm & Ta ppm & Th ppm & U ppm \\
\hline $\mathrm{SC}-7$ & 38.7 & 7.50 & 1.85 & 0.62 & 0.98 & 0.17 & 130 & 4.96 & 0.62 & 3.69 & 0.8 \\
\hline SC-13 (SC7dup) & 38.4 & 7.55 & 1.90 & 0.78 & 1.03 & 0.14 & 150 & 5.24 & 0.60 & 3.55 & 0.7 \\
\hline PVC5 & 10.9 & 1.69 & 0.42 & 0.24 & 0.27 & 0.05 & 65 & 0.55 & 0.60 & 1.47 & 1.1 \\
\hline 12A (PVC5 dup) & 7.8 & 1.60 & 0.40 & 0.05 & 0.06 & 0.06 & 0 & 0.31 & 0.14 & 0.63 & 0.7 \\
\hline NIST $1633-b$ values & 85 & 20 & 4.1 & 2.6 & 7.6 & 1.2 & $\mathrm{n} / \mathrm{a}$ & 6.8 & 1.8 & 25.7 & 8.79 \\
\hline SC-12(1633b) & 101 & 18.9 & 4.10 & 2.44 & 7.68 & 1.00 & 275 & 7.03 & 1.79 & 27.0 & 7.9 \\
\hline $13 \mathrm{~A}(1633 \mathrm{~b})$ & 90.9 & 18.8 & 4.09 & 2.99 & 8.35 & 1.06 & 530 & 6.31 & 1.86 & 27.7 & 7.9 \\
\hline average & 96.0 & 18.9 & 4.1 & 2.72 & 8.02 & 1.03 & 403 & 6.67 & 1.83 & 27.4 & 7.87 \\
\hline dev from accept $\%$ & 12.9 & -5.75 & -0.12 & 4.42 & 5.46 & -14.2 & & -1.91 & 1.39 & 6.42 & -10.5 \\
\hline USGS SDC-1 values & 40 & 8.2 & 1.7 & 1.2 & 4 & $\mathrm{n} / \mathrm{a}$ & 290 & 8.3 & 1.2 & 12 & 3.10 \\
\hline 14A(mica schist) & 45.7 & 8.35 & 1.65 & 1.18 & 4.32 & 0.58 & 365 & 9.02 & 1.27 & 13.2 & 2.64 \\
\hline SDC-1 (mica schist) & 37.9 & 7.81 & 1.74 & 1.14 & 3.99 & 0.60 & 265 & 9.31 & 1.26 & 12.4 & 2.59 \\
\hline average & 41.8 & 8.08 & 1.70 & 1.16 & 4.155 & 0.59 & 315 & 9.17 & 1.27 & 12.8 & 2.62 \\
\hline dev from accept $\%$ & 4.50 & -1.46 & -0.29 & -3.33 & 3.88 & & 8.62 & 10.42 & 5.42 & 6.67 & -15.6 \\
\hline
\end{tabular}


X-ray Fluorescence Analytical Data for Duplicates and Blind Standards

\begin{tabular}{|c|c|c|c|c|c|c|c|c|c|c|c|c|}
\hline & $\mathrm{SiO}_{2}$ wt. $\%$ & $\mathrm{TiO}_{2} \mathrm{wt}^{\circ} \%$ & $\mathrm{Al}_{2} \mathrm{O}_{3} \mathbf{w t} \%$ & $\mathrm{FeO}^{*} \mathrm{wt} \%$ & MnO wt \% & MgO wt $\%$ & $\mathrm{CaO} w \mathrm{wt} \%$ & $\mathrm{Na}_{2} \mathrm{O} w t \%$ & $\mathrm{~K}_{2} \mathrm{O} w \mathrm{w} \%$ & $\mathrm{P}_{2} \mathrm{O}_{5} \mathbf{w t} \%$ & $\mathrm{Ni}$ ppm & Cr ppm \\
\hline USGS SDC-1 values & 65.8 & 1.01 & 15.8 & $\mathrm{n} / \mathrm{a}$ & 0.088 & 1.69 & 1.4 & 2.05 & 3.28 & 0.16 & 38 & 64 \\
\hline SC-1 & 65.24 & 0.993 & 15.65 & 6.32 & 0.115 & 1.70 & 1.42 & 2.02 & 3.27 & 0.147 & 36 & 59 \\
\hline deviation from accepted $\%$ & -0.85 & -1.70 & -0.96 & & 30.8 & 0.50 & 1.31 & -1.54 & -0.43 & -8.09 & -3.99 & -8.13 \\
\hline \multirow{3}{*}{$\begin{array}{c}\text { SC-7 } \\
\text { SC-13 (SC-7 dup) }\end{array}$} & 42.95 & 2.375 & 11.44 & 11.02 & 0.151 & 16.54 & 1.76 & 0.11 & 1.13 & 0.193 & 360 & 810 \\
\hline & 43.00 & 2.404 & 11.63 & 11.08 & 0.148 & 16.55 & 1.73 & 0.11 & 1.14 & 0.197 & 361 & 821 \\
\hline & Sc ppm & V ppm & Ba ppm & Rb ppm & Sr ppm & Zr ppm & Y ppm & Nb ppm & Ga ppm & Cu ppm & Zn ppm & Pb ppm \\
\hline USGS SDC-1 values & 17 & 102 & 630 & 127 & 180 & 290 & $\mathrm{n} / \mathrm{a}$ & 21 & 21 & 30 & 103 & 25 \\
\hline $\mathrm{SC}-1$ & 15 & 99 & 641 & 124 & 183 & 313 & 39 & 18.1 & 20 & 28 & 101 & 22 \\
\hline deviation from accepted $\%$ & -14.1 & -3.33 & 1.81 & -2.05 & 1.39 & 7.86 & & -13.8 & -4.29 & -8.00 & -1.55 & -13.6 \\
\hline SC-7 & 16 & 141 & 599 & 51 & 53 & 217 & 16 & 11 & 16 & 120 & 193 & 4 \\
\hline \multirow[t]{2}{*}{ SC-13 (SC-7 dup) } & 17 & 143 & 605 & 51 & 52 & 179 & 16 & 12 & 15 & 121 & 195 & 4 \\
\hline & La ppm & Ce ppm & Th ppm & Nd ppm & U ppm & Cs ppm & & & & & & \\
\hline USGS SDC-1 values & 42 & 93 & 12 & 40 & 3.1 & 4 & & & & & & \\
\hline SC-1 & 43 & 96 & 10 & 42 & 4 & 4 & & & & & & \\
\hline deviation from accepted $\%$ & 3.33 & 3.01 & -15.8 & 5.00 & 35.5 & 0.00 & & & & & & \\
\hline $\mathrm{SC}-7$ & 26 & 64 & 2 & 37 & 1 & 3 & & & & & & \\
\hline SC-13 (SC-7 dup) & 26 & 66 & 4 & 37 & 1 & 3 & & & & & & \\
\hline
\end{tabular}




\section{Appendix C Results of k-Cluster Analyses}




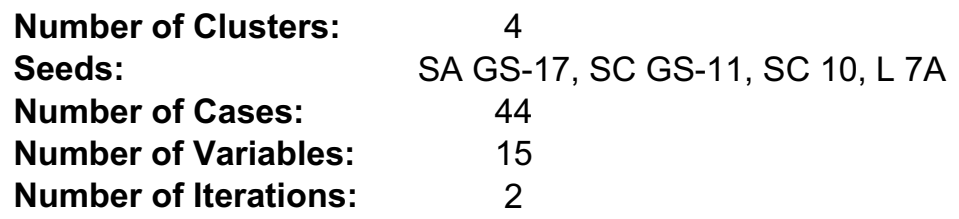

\begin{tabular}{|c|c|c|}
\hline Cluster \# & Members & $\begin{array}{l}\text { Distance } \\
\text { From Mean }\end{array}$ \\
\hline \multirow[t]{19}{*}{1} & L GS-4 & 0.412480 \\
\hline & L 5A & 0.755415 \\
\hline & L $3 A$ & 0.656409 \\
\hline & SA GS-1 & 0.783291 \\
\hline & L 9A & 0.548220 \\
\hline & L GS-2 & 0.474476 \\
\hline & L 7A & 0.239307 \\
\hline & L GS-10 & 0.813468 \\
\hline & L $1 \mathrm{~A}$ & 1.017736 \\
\hline & LA & 0.321739 \\
\hline & L 4A & 0.514271 \\
\hline & L 6A & 0.836704 \\
\hline & L 8A & 0.427209 \\
\hline & L10A & 0.909868 \\
\hline & L 11A & 0.438278 \\
\hline & P1 & 0.382675 \\
\hline & P4 & 0.307546 \\
\hline & P5 & 0.503818 \\
\hline & P6 & 0.498646 \\
\hline \multirow[t]{6}{*}{2} & SC6 & 0.319303 \\
\hline & SC9 & 0.469735 \\
\hline & SC10 & 0.325862 \\
\hline & SC4 & 0.275086 \\
\hline & SC5 & 0.484033 \\
\hline & SC11 & 0.885084 \\
\hline \multirow[t]{11}{*}{3} & SC GS-11 & 0.434205 \\
\hline & SC7 & 0.390553 \\
\hline & CH GS-16 & 0.262405 \\
\hline & CH GS-7 & 0.406576 \\
\hline & CH GS-12 & 0.465453 \\
\hline & SC GS-15 & 0.425174 \\
\hline & $\mathrm{SC} 2$ & 1.277526 \\
\hline & SC3 & 0.354497 \\
\hline & SC8 & 0.398839 \\
\hline & SC PVC5 & 0.452305 \\
\hline & P3 & 0.347564 \\
\hline \multirow[t]{8}{*}{4} & SA GS-17 & 0.189418 \\
\hline & SA PVC1 & 0.689490 \\
\hline & SA GS-13 & 0.449926 \\
\hline & SA GS-3 & 0.296435 \\
\hline & SA GS-18 & 0.313724 \\
\hline & SA PVC2 & 0.181403 \\
\hline & SA PVC3 & 0.188881 \\
\hline & $\mathrm{P} 2$ & 0.599834 \\
\hline
\end{tabular}




\begin{tabular}{|c|c|c|c|c|}
\hline \multirow[b]{2}{*}{ Variable } & \multicolumn{4}{|c|}{ Cluster Means (Copy4 of fprinttraceln1) } \\
\hline & $\begin{array}{c}\text { Cluster } \\
\text { No. } 1\end{array}$ & $\begin{array}{c}\text { Cluster } \\
\text { No. } 2\end{array}$ & $\begin{array}{c}\text { Cluster } \\
\text { No. } 3\end{array}$ & $\begin{array}{c}\text { Cluster } \\
\text { No. } 4\end{array}$ \\
\hline $\mathrm{SIO} 2$ & 3.778331 & 3.849233 & 3.867960 & 3.794851 \\
\hline L2O3 & 2.45 & 2.583347 & 79 & 2.274363 \\
\hline$=0$ & & 2.4 & 2.2 & 00 \\
\hline AO & 0.6 & 1.8 & & \\
\hline 20 & 1.7 & 1.44 & & 782 \\
\hline BA & 7.6 & 8.1 & & 6 \\
\hline & 4.2 & 3.7 & & 819 \\
\hline & 7 & 5.2 & & 03 \\
\hline & & 0.6 & & 2. \\
\hline CU & & 3.3 & & 873 \\
\hline LA & -0.15 & 4.134732 & 2.8 & 3.092121 \\
\hline NI & 5.20 & 4.10 & 6.0 & 131 \\
\hline & 2.7 & 3.3 & 2.4 & \\
\hline $\mathbf{V}$ & & 5.6 & & 415 \\
\hline & 4.021447 & 4.745518 & 4.815015 & 4.279053 \\
\hline
\end{tabular}

\begin{tabular}{|c|c|c|c|c|}
\hline \multirow{2}{*}{$\begin{array}{l}\text { Cluster } \\
\text { Number }\end{array}$} & \multicolumn{4}{|c|}{$\begin{array}{l}\text { Euclidean Distances between Clusters (Copy4 of fprinttraceln1) } \\
\text { Distances below diagonal } \\
\text { Squared distances above diagonal }\end{array}$} \\
\hline & No. 1 & No. 2 & No. 3 & No. 4 \\
\hline No. 1 & 0.000000 & 2.067298 & 1.171056 & 1.371823 \\
\hline No. 2 & 1.437810 & 0.000000 & 0.877303 & 1.185436 \\
\hline No. 3 & 1.082154 & 0.936645 & 0.000000 & 0.716966 \\
\hline No. 4 & 1.171248 & 1.088778 & 0.846738 & 0.000000 \\
\hline
\end{tabular}

\begin{tabular}{|c|c|c|c|c|c|c|}
\hline \multirow[b]{2}{*}{ Variable } & \multicolumn{6}{|c|}{ Analysis of Variance (Copy4 of fprinttraceln1) } \\
\hline & $\begin{array}{l}\text { Between } \\
\text { SS }\end{array}$ & df & $\begin{array}{c}\text { Within } \\
\text { SS }\end{array}$ & df & $\mathrm{F}$ & $\begin{array}{c}\text { signif. } \\
p\end{array}$ \\
\hline $\mathrm{SIO2}$ & 0.0666 & 3 & 0.15109 & 40 & 5.87464 & 0.002017 \\
\hline AL2O3 & 59 & 3 & 3.07 & 40 & 1.71547 & 0.179226 \\
\hline FEO & .7166 & 3 & 1.63 & 40 & 5.85262 & 0.002062 \\
\hline CAO & 8.7000 & 3 & 36.65877 & 40 & 3.16430 & 0.034771 \\
\hline 20 & 4.4964 & 3 & 19.58718 & 40 & 3.06079 & 39011 \\
\hline BA & 21.1820 & 3 & 14.97753 & 40 & 18.85672 & 0.000000 \\
\hline $\mathrm{CO}$ & .1181 & 3 & 1.39249 & 40 & 10.7 & 0.000027 \\
\hline & 25.1554 & 3 & 21.78276 & 40 & 15.39772 & 0. \\
\hline & 24 & 3 & 7.3 & 40 & 27.1 & 0000 \\
\hline CU & 41 & 3 & 29.9 & 40 & 15.6 & 0001 \\
\hline LA & 132.8996 & 3 & 36.66223 & 40 & 48.33298 & 0.000000 \\
\hline NI & 15.8496 & 3 & 8.10448 & 40 & 26.07544 & 0.000000 \\
\hline SC & 5.2903 & 3 & 7.8 & 40 & 9.02978 & 0.000109 \\
\hline 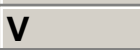 & 24.1772 & 3 & & 40 & 71.36324 & 0.000000 \\
\hline 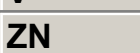 & 5.3980 & 3 & 3.51269 & 40 & 20.48969 & 0.000000 \\
\hline
\end{tabular}




\begin{tabular}{|l|r|r|r|r|}
\hline \multirow{2}{*}{ Variable } & \multicolumn{3}{|c|}{$\begin{array}{l}\text { Descriptive Statistics for Cluster 1 (Copy4 of fprinttraceln1) } \\
\text { Cluster contains 19 cases }\end{array}$} \\
\cline { 2 - 4 } & Mean & $\begin{array}{l}\text { Standard } \\
\text { Deviation }\end{array}$ & Variance & \\
\hline SIO2 & 3.778331 & 0.069376 & 0.004813 & \\
\hline AL2O3 & 2.459212 & 0.373250 & 0.139316 & \\
\hline FEO & 2.177033 & 0.248929 & 0.061966 & \\
\hline CAO & 0.654885 & 1.317984 & 1.737082 \\
\hline K2O & 1.739451 & 0.443557 & 0.196743 \\
\hline BA & 7.645436 & 0.535989 & 0.287284 \\
\hline CO & 4.236341 & 0.211589 & 0.044770 \\
\hline CR & 7.038855 & 0.619416 & 0.383676 \\
\hline CS & 1.629600 & 0.400257 & 0.160206 \\
\hline CU & 1.909796 & 1.047873 & 1.098038 \\
\hline LA & -0.197733 & 1.037418 & 1.076235 \\
\hline NI & 5.207242 & 0.349360 & 0.122053 \\
\hline SC & 2.750628 & 0.572148 & 0.327353 \\
V & 4.416292 & 0.351433 & 0.123505 \\
\hline ZN & 4.021447 & 0.369734 & 0.136703 \\
\hline
\end{tabular}

\begin{tabular}{|c|c|c|c|}
\hline \multirow[b]{2}{*}{ Variable } & \multicolumn{3}{|c|}{$\begin{array}{l}\text { Descriptive Statistics for Cluster } 2 \text { (Copy } 4 \text { of fprinttraceln1) } \\
\text { Cluster contains } 6 \text { cases }\end{array}$} \\
\hline & Mean & $\begin{array}{l}\text { Standard } \\
\text { Deviation } \\
\end{array}$ & Variance \\
\hline $\mathrm{SIO2}$ & 3.849233 & 0.064647 & 0.004179 \\
\hline AL2O3 & 2.583347 & 0.154465 & 0.023859 \\
\hline FEO & 2.433307 & 0.227939 & 0.051956 \\
\hline CAO & 1.867485 & 0.303384 & 0.092042 \\
\hline $\mathrm{K} 2 \mathrm{O}$ & 1.444872 & 0.323651 & 0.104750 \\
\hline BA & 8.182878 & 0.224827 & 0.050547 \\
\hline $\mathrm{CO}$ & 3.747972 & 0.202223 & 0.040894 \\
\hline CR & 5.215080 & 1.455548 & 2.118621 \\
\hline CS & 0.606405 & 0.295308 & 0.087207 \\
\hline CU & 3.366312 & 0.730764 & 0.534016 \\
\hline LA & 4.134732 & 0.505349 & 0.255378 \\
\hline NI & 4.101848 & 1.011453 & 1.023037 \\
\hline SC & 3.324568 & 0.203011 & 0.041213 \\
\hline V & 5.640415 & 0.278753 & 0.077703 \\
\hline ZN & 4.745518 & 0.246920 & 0.060970 \\
\hline
\end{tabular}




\begin{tabular}{|c|c|c|c|c|}
\hline \multirow[b]{2}{*}{ Variable } & \multicolumn{4}{|c|}{$\begin{array}{l}\text { Descriptive Statistics for Cluster } 3 \text { (Copy4 of fprinttraceln1) } \\
\text { Cluster contains } 11 \text { cases }\end{array}$} \\
\hline & Mean & $\begin{array}{l}\text { Standard } \\
\text { Deviation } \\
\end{array}$ & Variance & \\
\hline SIO2 & 3.867960 & 0.065264 & 0.004259 & \\
\hline AL2O3 & 2.511979 & 0.194600 & 0.037869 & \\
\hline FEO & 2.269980 & 0.148755 & 0.022128 & \\
\hline CAO & 1.108066 & 0.586298 & 0.343746 & \\
\hline K2O & 0.962538 & 1.244080 & 1.547736 & \\
\hline BA & 6.794402 & 0.962912 & 0.927199 & \\
\hline CO & 4.080889 & 0.152748 & 0.023332 & \\
\hline CR & 6.916371 & 0.642794 & 0.413184 & \\
\hline CS & 0.897954 & 0.625877 & 0.391722 & \\
\hline CU & 4.038102 & 0.561030 & 0.314755 & \\
\hline LA & 2.807034 & 0.740200 & 0.547896 & \\
\hline NI & 6.091285 & 0.241221 & 0.058188 & \\
\hline SC & 2.455241 & 0.270979 & 0.073429 & \\
\hline V & 5.034225 & 0.232013 & 0.053830 & \\
\hline $\mathrm{ZN}$ & 4.815015 & 0.250971 & 0.062987 & \\
\hline & \multicolumn{4}{|c|}{$\begin{array}{l}\text { Descriptive Statistics for Cluster } 4 \text { (Copy } 4 \text { of fprinttraceln1) } \\
\text { Cluster contains } 8 \text { cases }\end{array}$} \\
\hline Variable & Mean & $\begin{array}{l}\text { Standard } \\
\text { Deviation }\end{array}$ & Variance & \\
\hline $\mathrm{SIO2}$ & 3.794851 & 0.011730 & 0.000138 & \\
\hline AL2O3 & 2.274363 & 0.101026 & 0.010206 & \\
\hline FEO & 1.998000 & 0.071824 & 0.005159 & \\
\hline CAO & 1.518997 & 0.461925 & 0.213375 & \\
\hline $\mathrm{K} 2 \mathrm{O}$ & 1.663782 & 0.079901 & 0.006384 & \\
\hline BA & 6.091486 & 0.200601 & 0.040241 & \\
\hline $\mathrm{CO}$ & 4.161819 & 0.145818 & 0.021263 & \\
\hline CR & 5.510035 & 0.147189 & 0.021665 & \\
\hline CS & 2.367243 & 0.129757 & 0.016837 & \\
\hline $\mathrm{CU}$ & 3.241873 & 0.790193 & 0.624405 & \\
\hline LA & 3.092121 & 1.226735 & 1.504879 & \\
\hline NI & 5.124131 & 0.173400 & 0.030067 & \\
\hline SC & 2.156190 & 0.373953 & 0.139841 & \\
\hline V & 3.219415 & 0.441959 & 0.195328 & \\
\hline $\mathrm{ZN}$ & 4.279053 & 0.129461 & 0.016760 & \\
\hline
\end{tabular}


Number of Clusters:

Seeds:

Number of Cases:

Number of Variables:

Number of Iterations:
6

SA GS-17, SC GS-11, SC 10, L 7A, L 9A

44

15

2

\begin{tabular}{|c|c|c|}
\hline Cluster \# & Members & $\begin{array}{c}\text { Distance } \\
\text { From Mean } \\
\end{array}$ \\
\hline \multirow[t]{4}{*}{1} & L 9A & 0.244654 \\
\hline & L $1 \mathrm{~A}$ & 0.472058 \\
\hline & L 4A & 0.362217 \\
\hline & L10A & 0.353303 \\
\hline \multirow[t]{15}{*}{2} & L GS-4 & 0.353766 \\
\hline & L 5A & 0.702337 \\
\hline & L $3 A$ & 0.629236 \\
\hline & SA GS-1 & 0.775860 \\
\hline & L GS-2 & 0.436138 \\
\hline & L 7A & 0.217604 \\
\hline & L GS-10 & 0.785601 \\
\hline & LA & 0.281378 \\
\hline & L $6 A$ & 0.736967 \\
\hline & L 8A & 0.375317 \\
\hline & L 11A & 0.466517 \\
\hline & $\mathrm{P} 1$ & 0.318551 \\
\hline & $\mathrm{P} 4$ & 0.360606 \\
\hline & P5 & 0.411252 \\
\hline & P6 & 0.542717 \\
\hline \multirow[t]{6}{*}{3} & SC6 & 0.319303 \\
\hline & SC9 & 0.469735 \\
\hline & SC10 & 0.325862 \\
\hline & $\mathrm{SC} 4$ & 0.275086 \\
\hline & SC5 & 0.484033 \\
\hline & SC11 & 0.885084 \\
\hline \multirow[t]{11}{*}{4} & SC GS-11 & 0.434205 \\
\hline & SC7 & 0.390553 \\
\hline & CH GS-16 & 0.262405 \\
\hline & CH GS-7 & 0.406576 \\
\hline & CH GS-12 & 0.465453 \\
\hline & SC GS-15 & 0.425174 \\
\hline & $\mathrm{SC} 2$ & 1.277526 \\
\hline & SC3 & 0.354497 \\
\hline & SC8 & 0.398839 \\
\hline & SC PVC5 & 0.452305 \\
\hline & P3 & 0.347564 \\
\hline \multirow[t]{8}{*}{5} & SA GS-17 & 0.189418 \\
\hline & SA PVC1 & 0.689490 \\
\hline & SA GS-13 & 0.449926 \\
\hline & SA GS-3 & 0.296435 \\
\hline & SA GS-18 & 0.313724 \\
\hline & SA PVC2 & 0.181403 \\
\hline & SA PVC3 & 0.188881 \\
\hline & P2 & 0.599834 \\
\hline
\end{tabular}




\begin{tabular}{|l|c|c|c|c|c|}
\hline \multirow{4}{*}{ Variable } & \multicolumn{6}{|c|}{$\begin{array}{c}\text { Cluster Means (Copy2 of fprinttraceln1) } \\
\text { No. 1 }\end{array}$} & $\begin{array}{c}\text { Cluster } \\
\text { No. 2 }\end{array}$ & $\begin{array}{c}\text { Cluster } \\
\text { No. 3 }\end{array}$ & $\begin{array}{c}\text { Cluster } \\
\text { No. 4 }\end{array}$ & $\begin{array}{c}\text { Cluster } \\
\text { No. 5 }\end{array}$ \\
\hline SIO2 & 3.873115 & 3.753055 & 3.849233 & 3.867960 & 3.794851 \\
\hline AL2O3 & 1.880023 & 2.613662 & 2.583347 & 2.511979 & 2.274363 \\
\hline FEO & 1.895712 & 2.252052 & 2.433307 & 2.269980 & 1.998000 \\
\hline CAO & 2.601408 & 0.135813 & 1.867485 & 1.108066 & 1.518997 \\
\hline K2O & 1.020488 & 1.931175 & 1.444872 & 0.962538 & 1.663782 \\
\hline BA & 6.999165 & 7.817775 & 8.182878 & 6.794402 & 6.091486 \\
\hline CO & 4.084200 & 4.276913 & 3.747972 & 4.080889 & 4.161819 \\
\hline CR & 6.709892 & 7.126579 & 5.215080 & 6.916371 & 5.510035 \\
\hline CS & 1.258937 & 1.728443 & 0.606405 & 0.897954 & 2.367243 \\
\hline CU & 1.028537 & 2.144799 & 3.366312 & 4.038102 & 3.241873 \\
\hline LA & 0.005218 & -0.251854 & 4.134732 & 2.807034 & 3.092121 \\
\hline NI & 4.738605 & 5.332212 & 4.101848 & 6.091285 & 5.124131 \\
\hline SC & 3.276493 & 2.610398 & 3.324568 & 2.455241 & 2.156190 \\
\hline V & 4.145607 & 4.488474 & 5.640415 & 5.034225 & 3.219415 \\
\hline ZN & 3.488330 & 4.163612 & 4.745518 & 4.815015 & 4.279053 \\
\hline
\end{tabular}

\begin{tabular}{|c|c|c|c|c|c|}
\hline \multirow{2}{*}{$\begin{array}{l}\text { Cluster } \\
\text { Number }\end{array}$} & \multicolumn{5}{|c|}{$\begin{array}{l}\text { Euclidean Distances between Clusters (Copy2 of fprinttraceln1) } \\
\text { Distances below diagonal } \\
\text { Squared distances above diagonal }\end{array}$} \\
\hline & No. 1 & No. 2 & No. 3 & No. 4 & No. 5 \\
\hline No. 1 & 0.000000 & 0.758079 & 2.161219 & 1.663291 & 1.504669 \\
\hline No. 2 & 0.870677 & 0.000000 & 2.201848 & 1.199389 & 1.495993 \\
\hline No. 3 & 1.470109 & 1.483863 & 0.000000 & 0.877303 & 1.185436 \\
\hline No. 4 & 1.289686 & 1.095166 & 0.936645 & 0.000000 & 0.716966 \\
\hline No. 5 & 1.226650 & 1.223108 & 1.088778 & 0.846738 & 0.000000 \\
\hline
\end{tabular}

\begin{tabular}{|c|c|c|c|c|c|c|}
\hline \multirow[b]{2}{*}{ Variable } & \multicolumn{6}{|c|}{ Analysis of Variance (Copy2 of fprinttraceln1) } \\
\hline & $\begin{array}{l}\text { Between } \\
\text { SS }\end{array}$ & $d f$ & $\begin{array}{c}\text { Within } \\
\text { SS }\end{array}$ & df & $\mathrm{F}$ & $\begin{array}{c}\text { signif. } \\
\mathrm{p}\end{array}$ \\
\hline SIO2 & 0.1121 & 4 & 0.10557 & 39 & 10.35219 & 0.000008 \\
\hline L2O3 & .0956 & 4 & 1.37745 & 39 & 14.83304 & 0.000000 \\
\hline FEO & 1176 & 4 & 1.23157 & 39 & 61 & 035 \\
\hline CAO & 27.8973 & 4 & 17.46143 & 39 & 15.57711 & 0000 \\
\hline K2O & .1154 & 4 & 16.96818 & 39 & 4.08855 & 0.007317 \\
\hline BA & 23.2982 & 4 & 12.86135 & 39 & 17.66203 & 0000 \\
\hline $\mathrm{CO}$ & 54 & 4 & 21 & 39 & 51 & 0019 \\
\hline & 37 & 4 & 21.2 & 39 & 11 & 0 \\
\hline CS & 85 & 4 & 370 & 39 & 22.9 & 0000 \\
\hline CU & .0390 & 4 & 26.01829 & 39 & 14.6 & 0.000000 \\
\hline LA & 133.1083 & 4 & 36.45353 & 39 & 35.60165 & 0.000000 \\
\hline 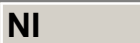 & 16.9623 & 4 & 6.99173 & 39 & 23.65405 & 0.000000 \\
\hline 50 & 6914 & 4 & 6.41050 & 39 & 10.17720 & 0.000010 \\
\hline V & 24.5484 & 4 & 4.14598 & 39 & 57.73003 & 0.000000 \\
\hline ZN & 6.8381 & 4 & 2.07267 & 39 & 32.16675 & 0.000000 \\
\hline
\end{tabular}




\begin{tabular}{|c|c|c|c|}
\hline \multirow[b]{2}{*}{ Variable } & \multicolumn{3}{|c|}{$\begin{array}{l}\text { Descriptive Statistics for Cluster } 1 \text { (Copy2 of fprinttraceln1 } \\
\text { Cluster contains } 4 \text { cases }\end{array}$} \\
\hline & Mean & $\begin{array}{l}\text { Standard } \\
\text { Deviation }\end{array}$ & Variance \\
\hline $\mathrm{SIO2}$ & 3.873115 & 0.053706 & 0.002884 \\
\hline AL2O3 & 1.880023 & 0.486421 & 0.236606 \\
\hline FEO & 1.895712 & 0.271284 & 0.073595 \\
\hline CAO & 2.601408 & 0.372423 & 0.138699 \\
\hline K2O & 1.020488 & 0.168720 & 0.028466 \\
\hline BA & 6.999165 & 0.445148 & 0.198157 \\
\hline $\mathrm{CO}$ & 4.084200 & 0.399849 & 0.159879 \\
\hline CR & 6.709892 & 0.726625 & 0.527984 \\
\hline CS & 1.258937 & 0.475329 & 0.225938 \\
\hline CU & 1.028537 & 0.352594 & 0.124322 \\
\hline LA & 0.005218 & 0.376154 & 0.141492 \\
\hline NI & 4.738605 & 0.250995 & 0.062999 \\
\hline SC & 3.276493 & 0.820677 & 0.673511 \\
\hline V & 4.145607 & 0.150538 & 0.022662 \\
\hline ZN & 3.488330 & 0.276401 & 0.076397 \\
\hline
\end{tabular}

\begin{tabular}{|c|c|c|c|}
\hline \multirow[b]{2}{*}{ Variable } & \multicolumn{3}{|c|}{$\begin{array}{l}\text { Descriptive Statistics for Cluster } 2 \text { (Copy2 of fprinttraceln } 1 \text { ) } \\
\text { Cluster contains } 15 \text { cases }\end{array}$} \\
\hline & Mean & $\begin{array}{l}\text { Standard } \\
\text { Deviation }\end{array}$ & Variance \\
\hline SIO2 & 3.753055 & 0.048153 & 0.002319 \\
\hline AL2O3 & 2.613662 & 0.083753 & 0.007015 \\
\hline FEO & 2.252052 & 0.187771 & 0.035258 \\
\hline CAO & 0.135813 & 0.912377 & 0.832431 \\
\hline K2O & 1.931175 & 0.244508 & 0.059784 \\
\hline BA & 7.817775 & 0.419223 & 0.175748 \\
\hline $\mathrm{CO}$ & 4.276913 & 0.122166 & 0.014924 \\
\hline CR & 7.126579 & 0.583947 & 0.340994 \\
\hline CS & 1.728443 & 0.328391 & 0.107841 \\
\hline CU & 2.144799 & 1.050743 & 1.104062 \\
\hline LA & -0.251854 & 1.156938 & 1.338505 \\
\hline NI & 5.332212 & 0.252870 & 0.063943 \\
\hline SC & 2.610398 & 0.420095 & 0.176480 \\
\hline V & 4.488474 & 0.356959 & 0.127420 \\
\hline ZN & 4.163612 & 0.237764 & 0.056532 \\
\hline
\end{tabular}




\begin{tabular}{|l|l|l|l|}
\hline \multirow{2}{*}{ Variable } & \multicolumn{3}{|l|}{$\begin{array}{l}\text { Descriptive Statistics for Cluster 3 (Copy2 of fprinttraceln1) } \\
\text { Cluster contains 6 cases }\end{array}$} \\
\cline { 2 - 4 } & Mean & $\begin{array}{l}\text { Standard } \\
\text { Deviation }\end{array}$ & Variance \\
\hline SIO2 & 3.849233 & 0.064647 & 0.004179 \\
\hline AL2O3 & 2.583347 & 0.154465 & 0.023859 \\
\hline FEO & 2.433307 & 0.227939 & 0.051956 \\
\hline CAO & 1.867485 & 0.303384 & 0.092042 \\
\hline K2O & 1.444872 & 0.323651 & 0.104750 \\
\hline BA & 8.182878 & 0.224827 & 0.050547 \\
\hline CO & 3.747972 & 0.202223 & 0.040894 \\
\hline CR & 5.215080 & 1.455548 & 2.118621 \\
\hline CS & 0.606405 & 0.295308 & 0.087207 \\
\hline CU & 3.366312 & 0.730764 & 0.534016 \\
\hline LA & 4.134732 & 0.505349 & 0.255378 \\
\hline NI & 4.101848 & 1.011453 & 1.023037 \\
\hline SC & 3.324568 & 0.203011 & 0.041213 \\
\hline V & 5.640415 & 0.278753 & 0.077703 \\
\hline ZN & 4.745518 & 0.246920 & 0.060970 \\
\hline
\end{tabular}

\begin{tabular}{|c|c|c|c|}
\hline \multirow[b]{2}{*}{ Variable } & \multicolumn{3}{|c|}{$\begin{array}{l}\text { Descriptive Statistics for Cluster } 4 \text { (Copy2 of fprinttraceln1) } \\
\text { Cluster contains } 11 \text { cases }\end{array}$} \\
\hline & Mean & $\begin{array}{l}\text { Standard } \\
\text { Deviation } \\
\end{array}$ & Variance \\
\hline $\mathrm{SIO2}$ & 3.867960 & 0.065264 & 0.004259 \\
\hline AL2O3 & 2.511979 & 0.194600 & 0.037869 \\
\hline FEO & 2.269980 & 0.148755 & 0.022128 \\
\hline CAO & 1.108066 & 0.586298 & 0.343746 \\
\hline K2O & 0.962538 & 1.244080 & 1.547736 \\
\hline BA & 6.794402 & 0.962912 & 0.927199 \\
\hline $\mathrm{CO}$ & 4.080889 & 0.152748 & 0.023332 \\
\hline CR & 6.916371 & 0.642794 & 0.413184 \\
\hline CS & 0.897954 & 0.625877 & 0.391722 \\
\hline CU & 4.038102 & 0.561030 & 0.314755 \\
\hline LA & 2.807034 & 0.740200 & 0.547896 \\
\hline NI & 6.091285 & 0.241221 & 0.058188 \\
\hline SC & 2.455241 & 0.270979 & 0.073429 \\
\hline V & 5.034225 & 0.232013 & 0.053830 \\
\hline $\mathrm{ZN}$ & 4.815015 & 0.250971 & 0.062987 \\
\hline
\end{tabular}




\begin{tabular}{|c|c|c|c|}
\hline \multirow[b]{2}{*}{ Variable } & \multicolumn{3}{|c|}{$\begin{array}{l}\text { Descriptive Statistics for Cluster } 5 \text { (Copy2 of fprinttraceln1 } \\
\text { Cluster contains } 8 \text { cases }\end{array}$} \\
\hline & Mean & $\begin{array}{l}\text { Standard } \\
\text { Deviation }\end{array}$ & Variance \\
\hline SIO2 & 3.794851 & 0.011730 & 0.000138 \\
\hline AL2O3 & 2.274363 & 0.101026 & 0.010206 \\
\hline FEO & 1.998000 & 0.071824 & $0.00515 \subseteq$ \\
\hline CAO & 1.518997 & 0.461925 & 0.213375 \\
\hline K2O & 1.663782 & 0.079901 & 0.006384 \\
\hline BA & 6.091486 & 0.200601 & 0.040241 \\
\hline $\mathrm{CO}$ & 4.161819 & 0.145818 & 0.021263 \\
\hline CR & 5.510035 & 0.147189 & 0.021665 \\
\hline CS & 2.367243 & 0.129757 & 0.016837 \\
\hline CU & 3.241873 & 0.790193 & 0.624405 \\
\hline LA & 3.092121 & 1.226735 & $1.50487 \mathrm{c}$ \\
\hline NI & 5.124131 & 0.173400 & 0.030067 \\
\hline SC & 2.156190 & 0.373953 & 0.139841 \\
\hline V & 3.219415 & 0.441959 & 0.195328 \\
\hline $\mathrm{ZN}$ & 4.279053 & 0.129461 & 0.016760 \\
\hline
\end{tabular}


Number of Clusters:

Seeds:

Number of Cases:

Number of Variables:

Number of Iterations:

\begin{tabular}{|c|c|c|}
\hline Cluster \# & Members & $\begin{array}{c}\text { Distance } \\
\text { From Mean }\end{array}$ \\
\hline \multirow[t]{4}{*}{1} & L 9A & 0.244654 \\
\hline & L $1 A$ & 0.472058 \\
\hline & L 4A & 0.362217 \\
\hline & L10A & 0.353303 \\
\hline \multirow[t]{8}{*}{2} & $\mathrm{~L} 7 \mathrm{~A}$ & 0.212526 \\
\hline & L 5A & 0.421248 \\
\hline & L $3 A$ & 0.438004 \\
\hline & SA GS-1 & 0.739775 \\
\hline & LA & 0.277824 \\
\hline & L $6 A$ & 0.593011 \\
\hline & L 11A & 0.525206 \\
\hline & P6 & 0.493268 \\
\hline \multirow[t]{7}{*}{3} & L GS-4 & 0.177267 \\
\hline & L GS-2 & 0.186228 \\
\hline & L GS-10 & 0.576599 \\
\hline & L 8A & 0.279981 \\
\hline & P1 & 0.116036 \\
\hline & P4 & 0.289965 \\
\hline & P5 & 0.165021 \\
\hline \multirow[t]{6}{*}{4} & SC6 & 0.319303 \\
\hline & SC9 & 0.469735 \\
\hline & SC10 & 0.325862 \\
\hline & SC4 & 0.275086 \\
\hline & SC5 & 0.484033 \\
\hline & SC11 & 0.885084 \\
\hline \multirow[t]{11}{*}{5} & SC GS-11 & 0.434205 \\
\hline & SC7 & 0.390553 \\
\hline & CH GS-16 & 0.262405 \\
\hline & CH GS-7 & 0.406576 \\
\hline & CH GS-12 & 0.465453 \\
\hline & SC GS-15 & 0.425174 \\
\hline & SC2 & 1.277526 \\
\hline & SC3 & 0.354497 \\
\hline & SC8 & 0.398839 \\
\hline & SC PVC5 & 0.452305 \\
\hline & P3 & 0.347564 \\
\hline \multirow[t]{8}{*}{6} & SA GS-17 & 0.189418 \\
\hline & SA PVC1 & 0.689490 \\
\hline & SA GS-13 & 0.449926 \\
\hline & SA GS-3 & 0.296435 \\
\hline & SA GS-18 & 0.313724 \\
\hline & SA PVC2 & 0.181403 \\
\hline & SA PVC3 & 0.188881 \\
\hline & P2 & 0.599834 \\
\hline
\end{tabular}

6

SA GS-17, SC GS-11, SC 10, L 7A, L 9A, L GS-4

44

15

2 


\begin{tabular}{|c|c|c|c|c|c|c|}
\hline \multirow[b]{2}{*}{ Variable } & \multicolumn{6}{|c|}{ Cluster Means (Copy2 of fprinttraceln1) } \\
\hline & $\begin{array}{c}\text { Cluster } \\
\text { No. } 1 \\
\end{array}$ & $\begin{array}{c}\text { Cluster } \\
\text { No. } 2 \\
\end{array}$ & $\begin{array}{c}\text { Cluster } \\
\text { No. } 3 \\
\end{array}$ & $\begin{array}{c}\text { Cluster } \\
\text { No. } 4 \\
\end{array}$ & $\begin{array}{c}\text { Cluster } \\
\text { No. } 5 \\
\end{array}$ & \begin{tabular}{|c|}
$\begin{array}{c}\text { Cluster } \\
\text { No. } 6\end{array}$ \\
\end{tabular} \\
\hline SIO2 & 3.873115 & 3.750070 & 3.75647 & 3.849233 & 3.867960 & 3.794851 \\
\hline-20 & 1.880023 & 2.598485 & 101 & 347 & 979 & 2.274363 \\
\hline FEO & 1.89 & 2.182992 & 098 & & 980 & 8000 \\
\hline CAO & 2.60 & -0.3 & 386 & & 066 & 3997 \\
\hline 20 & 020488 & 2.030982 & 1.81711 & 372 & 538 & 3782 \\
\hline BA & 99 & 7.7 & 7.85169 & & & 6.0 \\
\hline CO & 08 & 299 & 4. & & 389 & 4.1 \\
\hline & 6 & 46 & 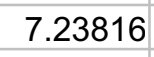 & & 371 & 5.5 \\
\hline 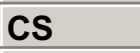 & 1.25 & 77 & 58 & & 954 & 2.367243 \\
\hline CU & 1.028537 & 1.346354 & 3.05731 & 3.3 & 4.038102 & 3.241873 \\
\hline LA & 0.0052 & 0.471740 & -1.07882 & 4.134732 & 2.807034 & 3.092121 \\
\hline NI & 73 & 5.3 & & & 6.0 & 5.1 \\
\hline & 21 & & & & 2.4 & 2.1 \\
\hline 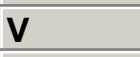 & 4.145607 & 4.324445 & 4.67594 & 15 & 5.034225 & 3.219415 \\
\hline $\mathbf{Z N}$ & 3.488330 & 4.082861 & 4.25590 & 4.745518 & 4.815015 & 4.279053 \\
\hline
\end{tabular}

\begin{tabular}{|l|c|c|c|c|c|c|}
\hline & \multicolumn{6}{|l|}{$\begin{array}{l}\text { Euclidean Distances between Clusters (Copy2 of fprinttraceln1, } \\
\text { Distances below diagonal } \\
\text { Squared distances above diagonal }\end{array}$} \\
\cline { 2 - 8 } $\begin{array}{l}\text { Cluster } \\
\text { Number }\end{array}$ & No. 1 & No. 2 & No. 3 & No. 4 & No. 5 & No. 6 \\
\hline No. 1 & 0.000000 & 0.838567 & 0.899746 & 2.161219 & 1.663291 & 1.504669 \\
\hline No. 2 & 0.915733 & 0.000000 & 0.438098 & 2.122024 & 1.285821 & 1.418282 \\
\hline No. 3 & 0.948549 & 0.661890 & 0.000000 & 2.526728 & 1.334262 & 1.818456 \\
\hline No. 4 & 1.470109 & 1.456717 & 1.589568 & 0.000000 & 0.877303 & 1.185436 \\
\hline No. 5 & 1.289686 & 1.133941 & 1.155103 & 0.936645 & 0.000000 & 0.716966 \\
\hline No. 6 & 1.226650 & 1.190917 & 1.348501 & 1.088778 & 0.846738 & 0.000000 \\
\hline
\end{tabular}

\begin{tabular}{|c|c|c|c|c|c|c|}
\hline \multirow[b]{2}{*}{ Variable } & \multicolumn{6}{|c|}{ Analysis of Variance (Copy2 of fprinttraceln1) } \\
\hline & $\begin{array}{c}\text { Between } \\
\text { SS }\end{array}$ & df & $\begin{array}{c}\text { Within } \\
\text { SS }\end{array}$ & df & $\mathrm{F}$ & $\begin{array}{c}\text { signif. } \\
\text { p }\end{array}$ \\
\hline $\mathrm{SIO} 2$ & 0.1122 & 5 & 0.10542 & 38 & 8.09210 & 0.000028 \\
\hline AL2O3 & 2.0995 & 5 & 1.37350 & 38 & 11.61725 & 0.000001 \\
\hline FEO & 1.1993 & 5 & 31 & 38 & 7.92739 & 0. \\
\hline CAO & 31.4197 & 5 & 13.9 & 38 & 17.13 & 0000 \\
\hline K2O & 62 & 5 & 16.7 & 38 & 3.29664 & 0.014341 \\
\hline BA & 23.3 & 5 & 12.8 & 38 & 13.7 & 0000 \\
\hline CO & 1.2442 & 5 & 1.2 & 38 & 7.46623 & 0058 \\
\hline CF & 71 & 5 & 21. & 38 & 9.3 & 0007 \\
\hline CS & 27 & 5 & 6. & 38 & 17.88 & 000 \\
\hline CU & 78 & 5 & 15.0 & 38 & 25.16683 & 0.000000 \\
\hline LA & 142.0841 & 5 & 27.47775 & 38 & 39.29867 & 0.000000 \\
\hline NI & 16.9677 & 5 & 6.98 & 38 & 18.45805 & 0.000000 \\
\hline $\mathrm{SC}$ & 14 & 5 & 6.3 & 38 & 8.12933 & 027 \\
\hline V & 25.0097 & 5 & & t & 51.58401 & 0.000000 \\
\hline ZN & 6.9498 & 5 & 1.96089 & 38 & 26.93617 & 0.000000 \\
\hline
\end{tabular}




\begin{tabular}{|c|c|c|c|}
\hline \multirow[b]{2}{*}{ Variable } & \multicolumn{3}{|c|}{$\begin{array}{l}\text { Descriptive Statistics for Cluster } 1 \text { (Copy2 of fprinttraceln1 } \\
\text { Cluster contains } 4 \text { cases }\end{array}$} \\
\hline & Mean & $\begin{array}{l}\text { Standard } \\
\text { Deviation }\end{array}$ & Variance \\
\hline $\mathrm{SIO2}$ & 3.873115 & 0.053706 & 0.002884 \\
\hline AL2O3 & 1.880023 & 0.486421 & 0.236606 \\
\hline FEO & 1.895712 & 0.271284 & 0.073595 \\
\hline CAO & 2.601408 & 0.372423 & 0.138699 \\
\hline K2O & 1.020488 & 0.168720 & 0.028466 \\
\hline BA & 6.999165 & 0.445148 & 0.198157 \\
\hline $\mathrm{CO}$ & 4.084200 & 0.399849 & 0.159879 \\
\hline CR & 6.709892 & 0.726625 & 0.527984 \\
\hline CS & 1.258937 & 0.475329 & 0.225938 \\
\hline CU & 1.028537 & 0.352594 & 0.124322 \\
\hline LA & 0.005218 & 0.376154 & 0.141492 \\
\hline NI & 4.738605 & 0.250995 & 0.062999 \\
\hline SC & 3.276493 & 0.820677 & 0.673511 \\
\hline V & 4.145607 & 0.150538 & 0.022662 \\
\hline ZN & 3.488330 & 0.276401 & 0.076397 \\
\hline
\end{tabular}

\begin{tabular}{|c|c|c|c|}
\hline \multirow[b]{2}{*}{ Variable } & \multicolumn{3}{|c|}{$\begin{array}{l}\text { Descriptive Statistics for Cluster } 2 \text { (Copy2 of fprinttraceln1) } \\
\text { Cluster contains } 8 \text { cases }\end{array}$} \\
\hline & Mean & $\begin{array}{l}\text { Standard } \\
\text { Deviation }\end{array}$ & Variance \\
\hline $\mathrm{SIO2}$ & 3.750070 & 0.065589 & 0.004302 \\
\hline AL2O3 & 2.598485 & 0.113176 & 0.012809 \\
\hline FEO & 2.182992 & 0.232292 & 0.053960 \\
\hline CAO & -0.317481 & 1.035240 & 1.071723 \\
\hline K2O & 2.030982 & 0.295395 & 0.087258 \\
\hline BA & 7.788103 & 0.563756 & 0.317820 \\
\hline $\mathrm{CO}$ & 4.254299 & 0.119839 & 0.014361 \\
\hline CR & 7.028946 & 0.769757 & 0.592526 \\
\hline CS & 1.744077 & 0.442181 & 0.195524 \\
\hline CU & 1.346354 & 0.748535 & 0.560305 \\
\hline LA & 0.471740 & 0.703330 & 0.494673 \\
\hline NI & 5.349915 & 0.319077 & 0.101810 \\
\hline SC & 2.678719 & 0.572141 & 0.327345 \\
\hline V & 4.324445 & 0.408673 & 0.167014 \\
\hline ZN & 4.082861 & 0.301427 & 0.090858 \\
\hline
\end{tabular}




\begin{tabular}{|l|r|r|r|r|}
\hline \multirow{4}{*}{ Variable } & \multicolumn{3}{|c|}{$\begin{array}{l}\text { Descriptive Statistics for Cluster 3 (Copy2 of fprinttraceln1) } \\
\text { Cluster contains 7 cases }\end{array}$} \\
\cline { 2 - 4 } & Mean & $\begin{array}{l}\text { Standard } \\
\text { Deviation }\end{array}$ & Variance & \\
\hline SIO2 & 3.75647 & 0.019132 & 0.000366 & \\
\hline AL2O3 & 2.63101 & 0.027667 & 0.000765 & \\
\hline FEO & 2.33098 & 0.075427 & 0.005689 \\
\hline CAO & 0.65386 & 0.323923 & 0.104926 \\
\hline K2O & 1.81711 & 0.096092 & 0.009234 \\
\hline BA & 7.85169 & 0.191760 & 0.036772 & \\
\hline CO & 4.30276 & 0.128871 & 0.016608 \\
\hline CR & 7.23816 & 0.277735 & 0.077137 \\
\hline CS & 1.71058 & 0.151061 & 0.022819 \\
\hline CU & 3.05731 & 0.317789 & 0.100990 \\
\hline LA & -1.07882 & 1.024741 & 1.050094 \\
\hline NI & 5.31198 & 0.171833 & 0.029526 \\
\hline SC & 2.53232 & 0.128637 & 0.016548 \\
\hline V & 4.67594 & 0.159971 & 0.025591 \\
\hline ZN & 4.25590 & 0.085297 & 0.007276 \\
\hline
\end{tabular}

\begin{tabular}{|c|c|c|c|}
\hline \multirow[b]{2}{*}{ Variable } & \multicolumn{3}{|c|}{$\begin{array}{l}\text { Descriptive Statistics for Cluster } 4 \text { (Copy2 of fprinttraceln1) } \\
\text { Cluster contains } 6 \text { cases }\end{array}$} \\
\hline & Mean & $\begin{array}{l}\text { Standard } \\
\text { Deviation }\end{array}$ & Variance \\
\hline SIO2 & 3.849233 & 0.064647 & 0.004179 \\
\hline AL2O3 & 2.583347 & 0.154465 & 0.023859 \\
\hline FEO & 2.433307 & 0.227939 & 0.051956 \\
\hline CAO & 1.867485 & 0.303384 & 0.092042 \\
\hline K2O & 1.444872 & 0.323651 & 0.104750 \\
\hline BA & 8.182878 & 0.224827 & 0.050547 \\
\hline $\mathrm{CO}$ & 3.747972 & 0.202223 & 0.040894 \\
\hline CR & 5.215080 & 1.455548 & 2.118621 \\
\hline CS & 0.606405 & 0.295308 & 0.087207 \\
\hline $\mathrm{CU}$ & 3.366312 & 0.730764 & 0.534016 \\
\hline LA & 4.134732 & 0.505349 & 0.255378 \\
\hline $\mathrm{NI}$ & 4.101848 & 1.011453 & 1.023037 \\
\hline SC & 3.324568 & 0.203011 & 0.041213 \\
\hline V & 5.640415 & 0.278753 & 0.077703 \\
\hline $\mathrm{ZN}$ & 4.745518 & 0.246920 & 0.060970 \\
\hline
\end{tabular}




\begin{tabular}{|c|c|c|c|c|}
\hline \multirow[b]{2}{*}{ Variable } & \multicolumn{4}{|c|}{$\begin{array}{l}\text { Descriptive Statistics for Cluster } 5 \text { (Copy2 of fprinttraceln1) } \\
\text { Cluster contains } 11 \text { cases }\end{array}$} \\
\hline & Mean & \begin{tabular}{l|} 
Standard \\
Deviation \\
\end{tabular} & Variance & \\
\hline SIO2 & 3.867960 & 0.065264 & 0.004259 & \\
\hline AL2O3 & 2.511979 & 0.194600 & 0.037869 & \\
\hline FEO & 2.269980 & 0.148755 & 0.022128 & \\
\hline CAO & 1.108066 & 0.586298 & 0.343746 & \\
\hline K2O & 0.962538 & 1.244080 & 1.547736 & \\
\hline BA & 6.794402 & 0.962912 & 0.927199 & \\
\hline $\mathrm{CO}$ & 4.080889 & 0.152748 & 0.023332 & \\
\hline CR & 6.916371 & 0.642794 & 0.413184 & \\
\hline CS & 0.897954 & 0.625877 & 0.391722 & \\
\hline $\mathrm{CU}$ & 4.038102 & 0.561030 & 0.314755 & \\
\hline LA & 2.807034 & 0.740200 & 0.547896 & \\
\hline NI & 6.091285 & 0.241221 & 0.058188 & \\
\hline SC & 2.455241 & 0.270979 & 0.073429 & \\
\hline V & 5.034225 & 0.232013 & 0.053830 & \\
\hline $\mathrm{ZN}$ & 4.815015 & 0.250971 & 0.062987 & \\
\hline & \multicolumn{4}{|c|}{$\begin{array}{l}\text { Descriptive Statistics for Cluster } 6 \text { (Copy2 of fprinttraceln1) } \\
\text { Cluster contains } 8 \text { cases }\end{array}$} \\
\hline Variable & Mean & $\begin{array}{l}\text { Standard } \\
\text { Deviation } \\
\end{array}$ & Variance & \\
\hline $\mathrm{SIO2}$ & 3.794851 & 0.011730 & 0.000138 & \\
\hline AL2O3 & 2.274363 & 0.101026 & 0.010206 & \\
\hline FEO & 1.998000 & 0.071824 & 0.005159 & \\
\hline CAO & 1.518997 & 0.461925 & 0.213375 & \\
\hline K2O & 1.663782 & 0.079901 & 0.006384 & \\
\hline BA & 6.091486 & 0.200601 & 0.040241 & \\
\hline $\mathrm{CO}$ & 4.161819 & 0.145818 & 0.021263 & \\
\hline CR & 5.510035 & 0.147189 & 0.021665 & \\
\hline CS & 2.367243 & 0.129757 & 0.016837 & \\
\hline $\mathrm{CU}$ & 3.241873 & 0.790193 & 0.624405 & \\
\hline LA & 3.092121 & 1.226735 & 1.504879 & \\
\hline NI & 5.124131 & 0.173400 & 0.030067 & \\
\hline SC & 2.156190 & 0.373953 & 0.139841 & \\
\hline V & 3.219415 & 0.441959 & 0.195328 & \\
\hline $\mathrm{ZN}$ & 4.279053 & 0.129461 & 0.016760 & \\
\hline
\end{tabular}




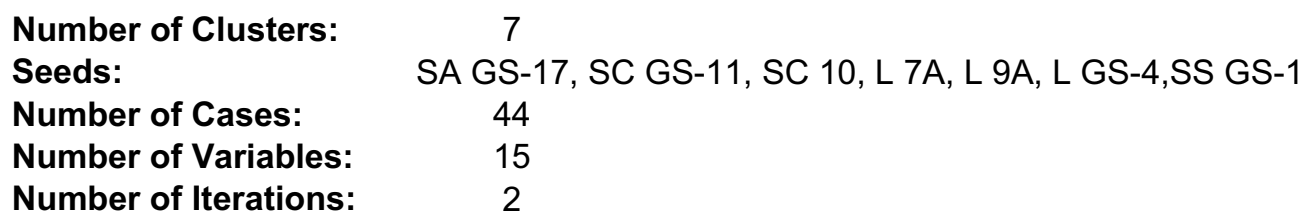

\begin{tabular}{|c|c|c|}
\hline Cluster \# & Members & $\begin{array}{c}\text { Distance } \\
\text { From Mean } \\
\end{array}$ \\
\hline \multirow[t]{6}{*}{1} & $L 3 A$ & 0.321940 \\
\hline & LA & 0.255551 \\
\hline & L 5A & 0.395374 \\
\hline & L 6A & 0.499871 \\
\hline & L 7A & 0.261557 \\
\hline & P6 & 0.541052 \\
\hline \multirow[t]{6}{*}{2} & SC6 & 0.319303 \\
\hline & SC9 & 0.469735 \\
\hline & SC10 & 0.325862 \\
\hline & SC4 & 0.275086 \\
\hline & SC5 & 0.484033 \\
\hline & SC11 & 0.885084 \\
\hline \multirow[t]{6}{*}{3} & SA GS-13 & 0.312145 \\
\hline & SA GS-3 & 0.261966 \\
\hline & SA GS-17 & 0.195952 \\
\hline & SA PVC2 & 0.258850 \\
\hline & SA PVC3 & 0.294314 \\
\hline & $\mathrm{P} 2$ & 0.498900 \\
\hline \multirow{11}{*}{4} & SC GS-11 & 0.434205 \\
\hline & SC2 & 1.277526 \\
\hline & CH GS-16 & 0.262405 \\
\hline & CH GS-7 & 0.406576 \\
\hline & CH GS-12 & 0.465453 \\
\hline & SC GS-15 & 0.425174 \\
\hline & SC3 & 0.354497 \\
\hline & SC7 & 0.390553 \\
\hline & SC8 & 0.398839 \\
\hline & SC PVC5 & 0.452305 \\
\hline & P3 & 0.347564 \\
\hline \multirow[t]{8}{*}{5} & L GS-4 & 0.140977 \\
\hline & L GS-2 & 0.183521 \\
\hline & L GS-10 & 0.642763 \\
\hline & L 8A & 0.229516 \\
\hline & L 11A & 0.542762 \\
\hline & $\mathrm{P} 1$ & 0.148714 \\
\hline & P4 & 0.235555 \\
\hline & P5 & 0.216429 \\
\hline \multirow[t]{4}{*}{6} & L 9A & 0.244654 \\
\hline & L $1 A$ & 0.472058 \\
\hline & L 4A & 0.362217 \\
\hline & L10A & 0.353303 \\
\hline \multirow[t]{3}{*}{7} & SA GS-1 & 0.398374 \\
\hline & SA GS-18 & 0.338640 \\
\hline & SA PVC1 & 0.309404 \\
\hline
\end{tabular}




\begin{tabular}{|l|r|c|c|c|c|c|c|}
\hline & \multicolumn{7}{|c|}{ Cluster Means (fprinttraceln1) } \\
\cline { 2 - 9 } Variable & $\begin{array}{c}\text { Cluster } \\
\text { No. 1 }\end{array}$ & $\begin{array}{c}\text { Cluster } \\
\text { No. 2 }\end{array}$ & $\begin{array}{c}\text { Cluster } \\
\text { No. 3 }\end{array}$ & $\begin{array}{c}\text { Cluster } \\
\text { No. 4 }\end{array}$ & $\begin{array}{c}\text { Cluster } \\
\text { No. 5 }\end{array}$ & $\begin{array}{c}\text { Cluster } \\
\text { No. 6 }\end{array}$ & $\begin{array}{c}\text { Cluster } \\
\text { No. 7 }\end{array}$ \\
\hline SIO2 & 3.722787 & 3.849233 & 3.793150 & 3.867960 & 3.757902 & 3.873115 & 3.831930 \\
\hline AL2O3 & 2.638675 & 2.583347 & 2.265747 & 2.511979 & 2.631519 & 1.880023 & 2.307050 \\
\hline FEO & 2.195737 & 2.433307 & 2.011653 & 2.269980 & 2.332720 & 1.895712 & 1.952893 \\
\hline CAO & -0.508148 & 1.867485 & 1.552011 & 1.108066 & 0.682779 & 2.601408 & 0.821253 \\
\hline K2O & 2.131755 & 1.444872 & 1.646838 & 0.962538 & 1.797547 & 1.020488 & 1.741980 \\
\hline BA & 8.028680 & 8.182878 & 6.032575 & 6.794402 & 7.828551 & 6.999165 & 6.334193 \\
\hline CO & 4.240338 & 3.747972 & 4.116030 & 4.080889 & 4.298275 & 4.084200 & 4.307943 \\
\hline CR & 7.329450 & 5.215080 & 5.522915 & 6.916371 & 7.196859 & 6.709892 & 5.429966 \\
\hline CS & 1.645485 & 0.606405 & 2.325357 & 0.897954 & 1.666555 & 1.258937 & 2.569033 \\
\hline CU & 1.042053 & 3.366312 & 3.526678 & 4.038102 & 2.996719 & 1.028537 & 2.240273 \\
\hline LA & 0.388797 & 4.134732 & 3.611703 & 2.807034 & -0.801337 & 0.005218 & 1.122284 \\
\hline NI & 5.430375 & 4.101848 & 5.157128 & 6.091285 & 5.297132 & 4.738605 & 5.024720 \\
\hline SC & 2.858697 & 3.324568 & 2.215982 & 2.455241 & 2.550046 & 3.276493 & 1.852350 \\
\hline V & 4.451203 & 5.640415 & 3.277335 & 5.034225 & 4.648238 & 4.145607 & 3.175100 \\
\hline ZN & 3.963297 & 4.745518 & 4.306278 & 4.815015 & 4.308714 & 3.488330 & 4.199813 \\
\hline
\end{tabular}

\begin{tabular}{|l|c|c|c|c|c|c|c|}
\hline \multirow{2}{*}{$\begin{array}{l}\text { Cluster } \\
\text { Number }\end{array}$} & \multicolumn{6}{|l|}{$\begin{array}{l}\text { Euclidean Distances between Clusters (fprinttraceln1) } \\
\text { Distances below diagonal } \\
\text { Squared distances above diagonal }\end{array}$} \\
\cline { 2 - 9 } & No. 1 & No. 2 & No. 3 & No. 4 & No. 5 & No. 6 & No. 7 \\
\hline No. 1 & 0.000000 & 2.363313 & 2.061789 & 1.519284 & 0.474652 & 0.955291 & 0.951489 \\
\hline No. 2 & 1.537307 & 0.000000 & 1.109993 & 0.877303 & 2.315574 & 2.161219 & 1.923806 \\
\hline No. 3 & 1.435893 & 1.053562 & 0.000000 & 0.702903 & 1.951840 & 1.807591 & 0.584609 \\
\hline No. 4 & 1.232592 & 0.936645 & 0.838393 & 0.000000 & 1.189627 & 1.663291 & 1.167020 \\
\hline No. 5 & 0.688950 & 1.521701 & 1.397083 & 1.090700 & 0.000000 & 0.832038 & 0.897492 \\
\hline No. 6 & 0.977390 & 1.470109 & 1.344467 & 1.289686 & 0.912161 & 0.000000 & 0.933194 \\
\hline No. 7 & 0.975443 & 1.387013 & 0.764597 & 1.080287 & 0.947360 & 0.966020 & 0.000000 \\
\hline
\end{tabular}

\begin{tabular}{|c|c|c|c|c|c|c|}
\hline \multirow[b]{2}{*}{ Variable } & \multicolumn{6}{|c|}{ Analysis of Variance (fprinttraceln1) } \\
\hline & $\begin{array}{c}\text { Between } \\
\text { SS }\end{array}$ & df & $\begin{array}{c}\text { Within } \\
\text { SS }\end{array}$ & df & $\mathrm{F}$ & $\begin{array}{c}\text { signif. } \\
\text { p }\end{array}$ \\
\hline $\mathrm{SIO2}$ & 0.1321 & 6 & 0.08555 & 37 & 9.52275 & 0.000002 \\
\hline-203 & 2.1892 & 6 & 1.28384 & 37 & 10.51533 & 0.000001 \\
\hline EO & 1.2876 & 6 & 1.06159 & 37 & 39 & 0.000027 \\
\hline CAO & 30.9164 & 6 & 14.44234 & 37 & 13.20084 & 0.000000 \\
\hline K2O & .5201 & 6 & 16.56346 & 37 & 2.79979 & 0.023943 \\
\hline BA & 25.4501 & 6 & 10.7 & 37 & 14.65459 & 0.000000 \\
\hline CO & 1.2993 & 6 & 1.21132 & 37 & 6.61 & 0.000082 \\
\hline & 9.1503 & 6 & 17.7 & 37 & 10.1 & 0.000001 \\
\hline CS & 236 & 6 & 5.5 & 37 & 18.4 & 0.000000 \\
\hline $\mathrm{CU}$ & 53.9977 & 6 & 11.0 & 37 & 30.1 & 0.000000 \\
\hline LA & 143.7562 & 6 & 25.80563 & 37 & 34.35284 & 0.000000 \\
\hline NI & 17.1512 & 6 & 6.80287 & 37 & 15.54721 & 0.000000 \\
\hline $\mathbf{s}$ & 8.0973 & 6 & 5.00459 & 37 & 9.97749 & 0.000002 \\
\hline V & 25.8529 & 6 & 2.84 & 37 & 56.10566 & 0.000000 \\
\hline $\mathrm{ZN}$ & 7.2667 & 6 & 1.64404 & 37 & 27.25686 & 0.000000 \\
\hline
\end{tabular}




\begin{tabular}{|c|c|c|c|}
\hline \multirow[b]{2}{*}{ Variable } & \multicolumn{3}{|c|}{$\begin{array}{l}\text { Descriptive Statistics for Cluster } 1 \text { (fprinttraceln1) } \\
\text { Cluster contains } 6 \text { cases }\end{array}$} \\
\hline & Mean & \begin{tabular}{|l|} 
Standard \\
Deviation \\
\end{tabular} & Variance \\
\hline SIO2 & 3.722787 & 0.028518 & 0.000813 \\
\hline AL2O3 & 2.638675 & 0.017218 & 0.000296 \\
\hline FEO & 2.195737 & 0.242360 & 0.058738 \\
\hline CAO & -0.508148 & 1.080191 & 1.166813 \\
\hline K2O & 2.131755 & 0.267516 & 0.071565 \\
\hline BA & 8.028680 & 0.151743 & 0.023026 \\
\hline $\mathrm{CO}$ & 4.240338 & 0.137213 & 0.018828 \\
\hline CR & 7.329450 & 0.390541 & 0.152522 \\
\hline CS & 1.645485 & 0.203293 & 0.041328 \\
\hline CU & 1.042053 & 0.548337 & 0.300673 \\
\hline LA & 0.388797 & 0.767337 & 0.588806 \\
\hline NI & 5.430375 & 0.329535 & 0.108594 \\
\hline SC & 2.858697 & 0.433768 & 0.188155 \\
\hline V & 4.451203 & 0.229305 & 0.052581 \\
\hline ZN & 3.963297 & 0.190107 & 0.036140 \\
\hline
\end{tabular}

\begin{tabular}{|l|l|l|l|}
\hline \multirow{2}{*}{ Variable } & \multicolumn{3}{|c|}{$\begin{array}{l}\text { Descriptive Statistics for Cluster 2 (fprinttraceln1) } \\
\text { Cluster contains 6 cases }\end{array}$} \\
\cline { 2 - 4 } & Mean & $\begin{array}{l}\text { Standard } \\
\text { Deviation }\end{array}$ & Variance \\
\hline SIO2 & 3.849233 & 0.064647 & 0.004179 \\
\hline AL2O3 & 2.583347 & 0.154465 & 0.023859 \\
\hline FEO & 2.433307 & 0.227939 & 0.051956 \\
\hline CAO & 1.867485 & 0.303384 & 0.092042 \\
\hline K2O & 1.444872 & 0.323651 & 0.104750 \\
\hline BA & 8.182878 & 0.224827 & 0.050547 \\
\hline CO & 3.747972 & 0.202223 & 0.040894 \\
\hline CR & 5.215080 & 1.455548 & 2.118621 \\
\hline CS & 0.606405 & 0.295308 & 0.087207 \\
\hline CU & 3.366312 & 0.730764 & 0.534016 \\
\hline LA & 4.134732 & 0.505349 & 0.255378 \\
\hline NI & 4.101848 & 1.011453 & 1.023037 \\
\hline SC & 3.324568 & 0.203011 & 0.041213 \\
\hline V & 5.640415 & 0.278753 & 0.077703 \\
\hline ZN & 4.745518 & 0.246920 & 0.060970 \\
\hline
\end{tabular}




\begin{tabular}{|l|l|l|l|}
\hline \multirow{2}{*}{ Variable } & \multicolumn{3}{|l|}{$\begin{array}{l}\text { Descriptive Statistics for Cluster 3 (fprinttraceln1) } \\
\text { Cluster contains 6 cases }\end{array}$} \\
\cline { 2 - 5 } & Mean & $\begin{array}{l}\text { Standard } \\
\text { Deviation }\end{array}$ & Variance \\
\hline SIO2 & 3.793150 & 0.011894 & 0.000141 \\
\hline AL2O3 & 2.265747 & 0.112460 & 0.012647 \\
\hline FEO & 2.011653 & 0.074342 & 0.005527 \\
\hline CAO & 1.552011 & 0.493022 & 0.243071 \\
K2O & 1.646838 & 0.086425 & 0.007469 \\
\hline BA & 6.032575 & 0.153988 & 0.023712 \\
\hline CO & 4.116030 & 0.129906 & 0.016876 \\
\hline CR & 5.522915 & 0.159604 & 0.025473 \\
\hline CS & 2.325357 & 0.122083 & 0.014904 \\
\hline CU & 3.526678 & 0.666112 & 0.443705 \\
\hline LA & 3.611703 & 0.804021 & 0.646450 \\
\hline NI & 5.157128 & 0.191000 & 0.036481 \\
\hline SC & 2.215982 & 0.403888 & 0.163125 \\
\hline V & 3.277335 & 0.406110 & 0.164926 \\
\hline ZN & 4.306278 & 0.128219 & 0.016440 \\
\hline
\end{tabular}

\begin{tabular}{|l|l|l|l|l|}
\hline \multirow{4}{*}{ Variable } & \multicolumn{3}{|l|}{$\begin{array}{l}\text { Descriptive Statistics for Cluster 4 (fprinttraceln1) } \\
\text { Cluster contains 11 cases }\end{array}$} \\
\cline { 2 - 4 } & Mean & $\begin{array}{l}\text { Standard } \\
\text { Deviation }\end{array}$ & Variance & \\
\hline SIO2 & 3.867960 & 0.065264 & 0.004259 \\
\hline AL2O3 & 2.511979 & 0.194600 & 0.037869 & \\
\hline FEO & 2.269980 & 0.148755 & 0.022128 \\
\hline CAO & 1.108066 & 0.586298 & 0.343746 \\
K2O & 0.962538 & 1.244080 & 1.547736 \\
\hline BA & 6.794402 & 0.962912 & 0.927199 \\
\hline CO & 4.080889 & 0.152748 & 0.023332 \\
\hline CR & 6.916371 & 0.642794 & 0.413184 \\
\hline CS & 0.897954 & 0.625877 & 0.391722 \\
\hline CU & 4.038102 & 0.561030 & 0.314755 \\
\hline LA & 2.807034 & 0.740200 & 0.547896 \\
NI & 6.091285 & 0.241221 & 0.058188 \\
\hline SC & 2.455241 & 0.270979 & 0.073429 \\
\hline V & 5.034225 & 0.232013 & 0.053830 \\
\hline ZN & 4.815015 & 0.250971 & 0.062987 \\
\hline
\end{tabular}




\begin{tabular}{|c|c|c|c|}
\hline \multirow[b]{2}{*}{ Variable } & \multicolumn{3}{|c|}{$\begin{array}{l}\text { Descriptive Statistics for Cluster } 5 \text { (fprinttraceln1) } \\
\text { Cluster contains } 8 \text { cases }\end{array}$} \\
\hline & Mean & \begin{tabular}{|l|} 
Standard \\
Deviation \\
\end{tabular} & Variance \\
\hline $\mathrm{SIO} 2$ & 3.757902 & 0.018173 & 0.000330 \\
\hline AL2O3 & 2.631519 & 0.025656 & 0.000658 \\
\hline FEO & 2.332720 & 0.070006 & 0.004901 \\
\hline CAO & 0.682779 & 0.310847 & 0.096626 \\
\hline K2O & 1.797547 & 0.104765 & 0.010976 \\
\hline BA & 7.828551 & 0.189212 & 0.035801 \\
\hline $\mathrm{CO}$ & 4.298275 & 0.119983 & 0.014396 \\
\hline CR & 7.196859 & 0.282423 & 0.079763 \\
\hline CS & 1.666555 & 0.187249 & 0.035062 \\
\hline CU & 2.996719 & 0.340483 & 0.115929 \\
\hline LA & -0.801337 & 1.231278 & 1.516046 \\
\hline NI & 5.297132 & 0.164537 & 0.027072 \\
\hline SC & 2.550046 & 0.129222 & 0.016698 \\
\hline V & 4.648238 & 0.167548 & 0.028072 \\
\hline $\mathrm{ZN}$ & 4.308714 & 0.168973 & 0.028552 \\
\hline
\end{tabular}

\begin{tabular}{|c|c|c|c|}
\hline \multirow[b]{2}{*}{ Variable } & \multicolumn{3}{|c|}{$\begin{array}{l}\text { Descriptive Statistics for Cluster } 6 \text { (fprinttraceln1) } \\
\text { Cluster contains } 4 \text { cases }\end{array}$} \\
\hline & Mean & $\begin{array}{l}\text { Standard } \\
\text { Deviation } \\
\end{array}$ & Variance \\
\hline $\mathrm{SIO2}$ & 3.873115 & 0.053706 & 0.002884 \\
\hline AL2O3 & 1.880023 & 0.486421 & 0.236606 \\
\hline FEO & 1.895712 & 0.271284 & 0.073595 \\
\hline CAO & 2.601408 & 0.372423 & 0.138699 \\
\hline $\mathrm{K} 2 \mathrm{O}$ & 1.020488 & 0.168720 & 0.028466 \\
\hline BA & 6.999165 & 0.445148 & 0.198157 \\
\hline $\mathrm{CO}$ & 4.084200 & 0.399849 & 0.159879 \\
\hline CR & 6.709892 & 0.726625 & 0.527984 \\
\hline CS & 1.258937 & 0.475329 & 0.225938 \\
\hline CU & 1.028537 & 0.352594 & 0.124322 \\
\hline LA & 0.005218 & 0.376154 & 0.141492 \\
\hline NI & 4.738605 & 0.250995 & 0.062999 \\
\hline SC & 3.276493 & 0.820677 & 0.673511 \\
\hline V & 4.145607 & 0.150538 & 0.022662 \\
\hline $\mathrm{ZN}$ & 3.488330 & 0.276401 & 0.076397 \\
\hline
\end{tabular}




\begin{tabular}{|l|l|l|l|}
\hline \multirow{2}{*}{ Variable } & \multicolumn{3}{|c|}{$\begin{array}{l}\text { Descriptive Statistics for Cluster 7 (fprinttraceln1) } \\
\text { Cluster contains 3 cases }\end{array}$} \\
\cline { 2 - 5 } & Mean & $\begin{array}{l}\text { Standard } \\
\text { Deviation }\end{array}$ & Variance \\
\hline SIO2 & 3.831930 & 0.056218 & 0.003160 \\
\hline AL2O3 & 2.307050 & 0.057905 & 0.003353 \\
\hline FEO & 1.952893 & 0.045313 & 0.002053 \\
\hline CAO & 0.821253 & 1.096079 & 1.201389 \\
\hline K2O & 1.741980 & 0.049725 & 0.002473 \\
\hline BA & 6.334193 & 0.230160 & 0.052973 \\
\hline CO & 4.307943 & 0.085452 & 0.007302 \\
\hline CR & 5.429966 & 0.123695 & 0.015300 \\
\hline CS & 2.569033 & 0.134179 & 0.018004 \\
CU & 2.240273 & 0.409596 & 0.167768 \\
\hline LA & 1.122284 & 0.958304 & 0.918347 \\
\hline NI & 5.024720 & 0.031119 & 0.000968 \\
\hline SC & 1.852350 & 0.291895 & 0.085203 \\
\hline V & 3.175100 & 0.530420 & 0.281345 \\
\hline ZN & 4.199813 & 0.093181 & 0.008683 \\
\hline
\end{tabular}


Number of Clusters:

\section{Seeds:}

Number of Cases:

Number of Variables:

Number of Iterations:

\begin{tabular}{|c|c|c|}
\hline Cluster \# & Members & $\begin{array}{c}\text { Distance } \\
\text { From Mean }\end{array}$ \\
\hline \multirow[t]{15}{*}{1} & L GS-4 & 0.353766 \\
\hline & L 5A & 0.702337 \\
\hline & $L 3 A$ & 0.629236 \\
\hline & SA GS-1 & 0.775860 \\
\hline & L GS-2 & 0.436138 \\
\hline & L 7A & 0.217604 \\
\hline & L GS-10 & 0.785601 \\
\hline & L A & 0.281378 \\
\hline & L $6 A$ & 0.736967 \\
\hline & L 8A & 0.375317 \\
\hline & L 11A & 0.466517 \\
\hline & $\mathrm{P} 1$ & 0.318551 \\
\hline & $\mathrm{P} 4$ & 0.360606 \\
\hline & P5 & 0.411252 \\
\hline & P6 & 0.542717 \\
\hline \multirow[t]{6}{*}{2} & SC6 & 0.319303 \\
\hline & SC9 & 0.469735 \\
\hline & SC10 & 0.325862 \\
\hline & SC4 & 0.275086 \\
\hline & SC5 & 0.484033 \\
\hline & SC11 & 0.885084 \\
\hline \multirow[t]{8}{*}{3} & SA GS-17 & 0.189418 \\
\hline & SA PVC1 & 0.689490 \\
\hline & SA GS-13 & 0.449926 \\
\hline & SA GS-3 & 0.296435 \\
\hline & SA GS-18 & 0.313724 \\
\hline & SA PVC2 & 0.181403 \\
\hline & SA PVC3 & 0.188881 \\
\hline & $\mathrm{P} 2$ & 0.599834 \\
\hline \multirow[t]{10}{*}{4} & SC GS-11 & 0.369949 \\
\hline & CH GS-7 & 0.403518 \\
\hline & CH GS-12 & 0.456103 \\
\hline & CH GS-16 & 0.223736 \\
\hline & SC GS-15 & 0.331403 \\
\hline & SC3 & 0.346930 \\
\hline & SC7 & 0.472495 \\
\hline & SC8 & 0.431193 \\
\hline & SC PVC5 & 0.376759 \\
\hline & P3 & 0.283669 \\
\hline \multirow[t]{4}{*}{5} & L9A & 0.244654 \\
\hline & $\mathrm{L} 1 \mathrm{~A}$ & 0.472058 \\
\hline & $\mathrm{L} 4 \mathrm{~A}$ & 0.362217 \\
\hline & L10A & 0.353303 \\
\hline 6 & SC2 & 0.000000 \\
\hline
\end{tabular}

SA GS-17, SC GS-11, SC 10, L 7A, L 9A, and CH GS-7 or CH GS-12 or Ch GS-16 44

15

2 


\begin{tabular}{|c|c|c|c|c|c|c|}
\hline \multirow[b]{2}{*}{ Variable } & \multicolumn{6}{|c|}{ Cluster Means (fprinttraceln1) } \\
\hline & $\begin{array}{c}\text { Cluster } \\
\text { No. } 1\end{array}$ & $\begin{array}{c}\text { Cluster } \\
\text { No. } 2\end{array}$ & $\begin{array}{c}\text { Cluster } \\
\text { No. } 3\end{array}$ & $\begin{array}{c}\text { Cluster } \\
\text { No. } 4\end{array}$ & $\begin{array}{c}\text { Cluster } \\
\text { No. } 5\end{array}$ & $\begin{array}{c}\text { Cluster } \\
\text { No. } 6\end{array}$ \\
\hline SIO2 & 3.753055 & 3.849233 & 3.794851 & 3.863054 & 3.873115 & 3.91702 \\
\hline AL2O3 & 2.61 & 2.583347 & 2.274363 & 2.560960 & 1.880023 & 2.02217 \\
\hline FEO & 2.2 & 2.43 & 1.998000 & 2.26 & 1.895712 & 2.35537 \\
\hline CAO & 0.13 & 1.86 & 1.51 & 1.10 & 2.601408 & 1.10356 \\
\hline K2O & 175 & 1.444872 & 1.66 & 1.3 & 1.020488 & -2.53834 \\
\hline BA & 7.817775 & 8.18 & 6.0 & 7.0 & 165 & 4.25845 \\
\hline CO & 4.27 & 3.74 & 4.16 & 4.058978 & 4.084200 & 4.30000 \\
\hline CR & 9 & 5.2 & 5.5 & 7.0 & 892 & 5.43372 \\
\hline CS & 3 & 0.6 & 2.3 & 1.0 & 937 & -0.65585 \\
\hline CU & 2.14 & 3.36 & 3.2 & 4.0 & 1.028537 & 3.43399 \\
\hline LA & -0.251854 & 4.134732 & 3.092121 & 2.790184 & 0.005218 & 2.97553 \\
\hline NI & 5.332212 & 4.101848 & 5.124131 & 6.059717 & 4.738605 & 6.40697 \\
\hline SC & & 3.32 & 2.1 & 2.464680 & 3.276493 & 2.36085 \\
\hline V & & 5.64 & 3.2 & $5.0 \varepsilon$ & 4.145607 & 4.48976 \\
\hline $\mathrm{ZN}$ & 4.163612 & 4.745518 & 4.279053 & 4.844230 & 3.488330 & 4.52287 \\
\hline
\end{tabular}

\begin{tabular}{|l|c|c|c|c|c|c|}
\hline \multirow{2}{*}{$\begin{array}{l}\text { Cluster } \\
\text { Number }\end{array}$} & \multicolumn{6}{|l|}{$\begin{array}{l}\text { Euclidean Distances between Clusters (fprinttraceln1) } \\
\text { Distances below diagonal } \\
\text { Squared distances above diagonal }\end{array}$} \\
\cline { 2 - 8 } & No. 1 & No. 2 & No. 3 & No. 4 & No. 5 & No. 6 \\
\hline No. 1 & 0.000000 & 2.201848 & 1.495993 & 1.125890 & 0.758079 & 3.729663 \\
\hline No. 2 & 1.483863 & 0.000000 & 1.185436 & 0.857319 & 2.161219 & 2.872424 \\
\hline No. 3 & 1.223108 & 1.088778 & 0.000000 & 0.741711 & 1.504669 & 2.264799 \\
\hline No. 4 & 1.061080 & 0.925915 & 0.861226 & 0.000000 & 1.693049 & 1.974809 \\
\hline No. 5 & 0.870677 & 1.470109 & 1.226650 & 1.301172 & 0.000000 & 3.160991 \\
\hline No. 6 & 1.931234 & 1.694823 & 1.504925 & 1.405279 & 1.777918 & 0.000000 \\
\hline
\end{tabular}

\begin{tabular}{|c|c|c|c|c|c|c|}
\hline \multirow[b]{2}{*}{ Variable } & \multicolumn{6}{|c|}{ Analysis of Variance (fprinttraceln1) } \\
\hline & $\begin{array}{c}\text { Between } \\
\text { SS }\end{array}$ & df & $\begin{array}{c}\text { Within } \\
\text { SS }\end{array}$ & df & $\mathrm{F}$ & $\begin{array}{c}\text { signif. } \\
\text { p }\end{array}$ \\
\hline $\mathrm{SIO} 2$ & 0.1147 & 5 & 0.10292 & 38 & 8.47248 & 0.000019 \\
\hline AL2O3 & 2.3595 & 5 & 1.11355 & 38 & 16.10348 & 0.000000 \\
\hline FEO & 1.1256 & 5 & 1.28 & 38 & 163 & 0.000102 \\
\hline CAO & 27.8973 & 5 & 17.46141 & 38 & 12.14218 & 0.000000 \\
\hline K2O & 20.5972 & 5 & 3.48641 & 38 & 44.89960 & 0.000000 \\
\hline BA & 30.3724 & 5 & 5.7 & 38 & 39.88636 & 0.000000 \\
\hline CO & 1.2882 & 5 & 1.22 & 38 & 8.00 & 0.000031 \\
\hline $\mathbf{R}$ & 28. & 5 & 18.8 & 38 & 11.3 & 0.000001 \\
\hline CS & 43 & 5 & 4.0 & 38 & 34.7 & 0.0 \\
\hline CU & 39.4404 & 5 & 25.6 & 38 & 11.70118 & 0.000001 \\
\hline LA & 133.1395 & 5 & 36.42231 & 38 & 27.78133 & 0.000000 \\
\hline NI & 17.0720 & 5 & 6.88211 & 38 & 18.85277 & 0.000000 \\
\hline SC & 6.7012 & 5 & 6.40070 & 38 & 7.95678 & 0.000033 \\
\hline $\mathbf{V}$ & 24.8745 & 5 & 3.81 & 38 & 49.49002 & 0.000000 \\
\hline ZN & 6.9319 & 5 & 1.97879 & 38 & 26.62377 & 0.000000 \\
\hline
\end{tabular}




\begin{tabular}{|c|c|c|c|}
\hline \multirow[b]{2}{*}{ Variable } & \multicolumn{3}{|c|}{$\begin{array}{l}\text { Descriptive Statistics for Cluster } 1 \text { (fprinttraceln1) } \\
\text { Cluster contains } 15 \text { cases }\end{array}$} \\
\hline & Mean & $\begin{array}{l}\text { Standard } \\
\text { Deviation }\end{array}$ & Variance \\
\hline $\mathrm{SIO} 2$ & 3.753055 & 0.048153 & 0.002319 \\
\hline AL2O3 & 2.613662 & 0.083753 & 0.007015 \\
\hline FEO & 2.252052 & 0.187771 & 0.035258 \\
\hline CAO & 0.135813 & 0.912377 & 0.832431 \\
\hline K2O & 1.931175 & 0.244508 & 0.059784 \\
\hline BA & 7.817775 & 0.419223 & 0.175748 \\
\hline $\mathrm{CO}$ & 4.276913 & 0.122166 & 0.014924 \\
\hline CR & 7.126579 & 0.583947 & 0.340994 \\
\hline CS & 1.728443 & 0.328391 & 0.107841 \\
\hline CU & 2.144799 & 1.050743 & 1.104062 \\
\hline LA & -0.251854 & 1.156938 & 1.338505 \\
\hline NI & 5.332212 & 0.252870 & 0.063943 \\
\hline SC & 2.610398 & 0.420095 & 0.176480 \\
\hline V & 4.488474 & 0.356959 & 0.127420 \\
\hline $\mathrm{ZN}$ & 4.163612 & 0.237764 & 0.056532 \\
\hline
\end{tabular}

\begin{tabular}{|l|l|l|l|l|}
\hline \multirow{4}{*}{ Variable } & \multicolumn{3}{|c|}{$\begin{array}{l}\text { Descriptive Statistics for Cluster 2 (fprinttraceln1) } \\
\text { Cluster contains 6 cases }\end{array}$} \\
\cline { 2 - 5 } & Mean & $\begin{array}{l}\text { Standard } \\
\text { Deviation }\end{array}$ & Variance & \\
\hline SIO2 & 3.849233 & 0.064647 & 0.004179 & \\
\hline AL2O3 & 2.583347 & 0.154465 & 0.023859 \\
\hline FEO & 2.433307 & 0.227939 & 0.051956 & \\
\hline CAO & 1.867485 & 0.303384 & 0.092042 \\
\hline K2O & 1.444872 & 0.323651 & 0.104750 \\
\hline BA & 8.182878 & 0.224827 & 0.050547 \\
\hline CO & 3.747972 & 0.202223 & 0.040894 \\
\hline CR & 5.215080 & 1.455548 & 2.118621 \\
\hline CS & 0.606405 & 0.295308 & 0.087207 \\
\hline CU & 3.366312 & 0.730764 & 0.534016 \\
\hline LA & 4.134732 & 0.505349 & 0.255378 \\
\hline NI & 4.101848 & 1.011453 & 1.023037 \\
\hline SC & 3.324568 & 0.203011 & 0.041213 \\
V & 5.640415 & 0.278753 & 0.077703 \\
\hline ZN & 4.745518 & 0.246920 & 0.060970 \\
\hline
\end{tabular}




\begin{tabular}{|c|c|c|c|}
\hline \multirow[b]{2}{*}{ Variable } & \multicolumn{3}{|c|}{$\begin{array}{l}\text { Descriptive Statistics for Cluster } 3 \text { (fprinttraceln1) } \\
\text { Cluster contains } 8 \text { cases }\end{array}$} \\
\hline & Mean & $\begin{array}{l}\text { Standard } \\
\text { Deviation }\end{array}$ & Variance \\
\hline $\mathrm{SIO} 2$ & 3.794851 & 0.011730 & 0.000138 \\
\hline AL2O3 & 2.274363 & 0.101026 & 0.010206 \\
\hline FEO & 1.998000 & 0.071824 & 0.005159 \\
\hline CAO & 1.518997 & 0.461925 & 0.213375 \\
\hline K2O & 1.663782 & 0.079901 & 0.006384 \\
\hline BA & 6.091486 & 0.200601 & 0.040241 \\
\hline $\mathrm{CO}$ & 4.161819 & 0.145818 & 0.021263 \\
\hline CR & 5.510035 & 0.147189 & 0.021665 \\
\hline CS & 2.367243 & 0.129757 & 0.016837 \\
\hline CU & 3.241873 & 0.790193 & 0.624405 \\
\hline LA & 3.092121 & 1.226735 & 1.504879 \\
\hline NI & 5.124131 & 0.173400 & 0.030067 \\
\hline SC & 2.156190 & 0.373953 & 0.139841 \\
\hline V & 3.219415 & 0.441959 & 0.195328 \\
\hline $\mathrm{ZN}$ & 4.279053 & 0.129461 & 0.016760 \\
\hline
\end{tabular}

\begin{tabular}{|l|l|l|l|l|}
\hline \multirow{4}{*}{ Variable } & \multicolumn{3}{|l|}{$\begin{array}{l}\text { Descriptive Statistics for Cluster 4 (fprinttraceln1) } \\
\text { Cluster contains 10 cases }\end{array}$} \\
\cline { 2 - 4 } & Mean & $\begin{array}{l}\text { Standard } \\
\text { Deviation }\end{array}$ & Variance & \\
\hline SIO2 & 3.863054 & 0.066622 & 0.004438 \\
\hline AL2O3 & 2.560960 & 0.112934 & 0.012754 \\
FEO & 2.261441 & 0.153934 & 0.023696 \\
\hline CAO & 1.108516 & 0.618011 & 0.381937 \\
\hline K2O & 1.312626 & 0.470885 & 0.221733 \\
\hline BA & 7.047997 & 0.494170 & 0.244204 \\
\hline CO & 4.058978 & 0.141621 & 0.020057 \\
\hline CR & 7.064636 & 0.436369 & 0.190418 \\
\hline CS & 1.053334 & 0.374386 & 0.140165 \\
\hline CU & 4.098513 & 0.552379 & 0.305123 \\
\hline LA & 2.790184 & 0.778013 & 0.605303 \\
NI & 6.059717 & 0.229069 & 0.052473 \\
\hline SC & 2.464680 & 0.283724 & 0.080499 \\
\hline V & 5.088672 & 0.153556 & 0.023579 \\
\hline ZN & 4.844230 & 0.244036 & 0.059554 \\
\hline
\end{tabular}




\begin{tabular}{|c|c|c|c|}
\hline \multirow[b]{2}{*}{ Variable } & \multicolumn{3}{|c|}{$\begin{array}{l}\text { Descriptive Statistics for Cluster } 5 \text { (fprinttraceln1) } \\
\text { Cluster contains } 4 \text { cases }\end{array}$} \\
\hline & Mean & $\begin{array}{l}\text { Standard } \\
\text { Deviation }\end{array}$ & Variance \\
\hline SIO2 & 3.873115 & 0.053706 & 0.002884 \\
\hline AL2O3 & 1.880023 & 0.486421 & 0.236606 \\
\hline FEO & \begin{tabular}{|l|}
1.895712 \\
\end{tabular} & 0.271284 & 0.073595 \\
\hline CAO & 2.601408 & 0.372423 & 0.138699 \\
\hline K2O & 1.020488 & 0.168720 & 0.028466 \\
\hline BA & 6.999165 & 0.445148 & 0.198157 \\
\hline CO & 4.084200 & 0.399849 & 0.159879 \\
\hline CR & 6.709892 & 0.726625 & 0.527984 \\
\hline CS & 1.258937 & 0.475329 & 0.225938 \\
\hline CU & 1.028537 & 0.352594 & 0.124322 \\
\hline LA & 0.005218 & 0.376154 & 0.141492 \\
\hline NI & 4.738605 & 0.250995 & 0.062999 \\
\hline SC & 3.276493 & 0.820677 & 0.673511 \\
\hline V & 4.145607 & 0.150538 & 0.022662 \\
\hline ZN & 3.488330 & 0.276401 & 0.076397 \\
\hline
\end{tabular}

\begin{tabular}{|l|r|r|r|r|}
\hline \multirow{2}{*}{ Variable } & \multicolumn{3}{|l|}{$\begin{array}{l}\text { Descriptive Statistics for Cluster 6 (fprinttraceln1) } \\
\text { Cluster contains 1 cases }\end{array}$} \\
\cline { 2 - 4 } & \multicolumn{1}{|c|}{ Mean } & $\begin{array}{l}\text { Standard } \\
\text { Deviation }\end{array}$ & Variance & \\
\hline SIO2 & 3.91702 & 0.00 & 0.00 \\
\hline AL2O3 & 2.02217 & 0.00 & 0.00 \\
\hline FEO & 2.35537 & 0.00 & 0.00 \\
\hline CAO & 1.10356 & 0.00 & 0.00 \\
\hline K2O & -2.53834 & 0.00 & 0.00 \\
\hline BA & 4.25845 & 0.00 & 0.00 \\
CO & 4.30000 & 0.00 & 0.00 \\
\hline CR & 5.43372 & 0.00 & 0.00 \\
\hline CS & -0.65585 & 0.00 & 0.00 \\
\hline CU & 3.43399 & 0.00 & 0.00 \\
\hline LA & 2.97553 & 0.00 & 0.00 \\
\hline NI & 6.40697 & 0.00 & 0.00 \\
\hline SC & 2.36085 & 0.00 & 0.00 \\
\hline V & 4.48976 & 0.00 & 0.00 \\
\hline ZN & 4.52287 & 0.00 & 0.00 \\
\hline
\end{tabular}




\begin{abstract}
Appendix D
Results of Four-Category Discriminant Analyses
\end{abstract}




\section{Four-Category Model, Original Element Set}

Element Set:

$\mathrm{SiO}_{2}, \mathrm{TiO}_{2}, \mathrm{Al}_{2} \mathrm{O} 3, \mathrm{FeO}, \mathrm{MnO}, \mathrm{CaO}, \mathrm{Na}_{2} \mathrm{O}, \mathrm{K}_{2} \mathrm{O}, \mathrm{Ba}, \mathrm{Ce}, \mathrm{Co}, \mathrm{Cr}, \mathrm{Cs}, \mathrm{Cu}, \mathrm{Ga}, \mathrm{La}, \mathrm{Ni}, \mathrm{Sc}, \mathrm{Sm} \mathrm{V}$, $\mathrm{Zn}$

\section{Categories:}

\begin{tabular}{|l|c|l|c|}
\hline \multicolumn{1}{|c|}{ Category } & Abbreviation & \multicolumn{1}{|c|}{ Sample IDs } & $\begin{array}{c}\text { No. } \\
\text { Samples }\end{array}$ \\
\hline South Africa & SA & GS-1, GS-3, GS-13, GS-17, GS-18,PVC1, PVC2, PVC3 & 8 \\
China & CH & GS-7, GS-12, GS-16 & 3 \\
South Carolina & SC & $\begin{array}{l}\text { GS-11, SG-15, SC2, SC3, SC4, SC5, SC6, SC7, SC8, } \\
\text { SC9, SC10, SC11, PVC5 }\end{array}$ & 13 \\
Libby & L & $\begin{array}{l}\text { GS-2, GS-4, GS-10, 1A, 2A, 3A, 4A, 5A, 6A, 7A, 8A, } \\
\text { 9A, 10A, 11A }\end{array}$ & 14 \\
\hline \multicolumn{2}{|c|}{ Total Number of Samples = } \\
\hline
\end{tabular}

Discriminant Function Analysis.

\begin{tabular}{|c|c|c|c|c|c|c|c|}
\hline \multirow{2}{*}{$\begin{array}{l}\mathrm{N}=38 \\
\text { Step }\end{array}$} & \multicolumn{7}{|c|}{$\begin{array}{l}\text { Discriminant Function Analysis Summary (fprinttraceln1) } \\
\text { Step 10, N of vars in model: 10; Grouping: Category (4 grps) } \\
\text { Wilks' Lambda: } .00044 \text { approx. F }(30,74)=32.014 p<0.0000\end{array}$} \\
\hline & $\begin{array}{l}\text { Element } \\
\text { Added }\end{array}$ & Wilks' $\Lambda$ & $\begin{array}{c}\text { Wilks' } \\
\text { Partial } \Lambda\end{array}$ & F-Remove & p-Level & Tolerance & $\begin{array}{c}\text { Correlated Variables } \\
\text { Removed }\end{array}$ \\
\hline 1 & V & 0.00228 & 0.1910 & 35.29 & 3.8443E-09 & 0.2960 & $\mathrm{TiO}_{2}, \mathrm{MnO}, \mathrm{Na}_{2} \mathrm{O}, \mathrm{Cs}$ \\
\hline 2 & $\mathrm{Sm}$ & 0.00173 & 0.2522 & 24.71 & $1.1951 \mathrm{E}-07$ & 0.2305 & $\mathrm{La}, \mathrm{Ce}$ \\
\hline 3 & Sc & 0.00221 & 0.1972 & 33.93 & 5.6882E-09 & 0.1084 & none \\
\hline 4 & $\mathrm{Ni}$ & 0.00153 & 0.2843 & 20.98 & $5.2351 \mathrm{E}-07$ & 0.1600 & none \\
\hline 5 & $\mathrm{Ga}$ & 0.00074 & 0.5843 & 5.93 & $3.3631 \mathrm{E}-03$ & 0.2003 & $\mathrm{Al}_{2} \mathrm{O}_{3}$ \\
\hline 6 & $\mathrm{~K}_{2} \mathrm{O}$ & 0.00125 & 0.3478 & 15.62 & 6.2577E-06 & 0.1174 & none \\
\hline 7 & $\mathrm{Ba}$ & 0.00087 & 0.5018 & 8.27 & $5.4278 \mathrm{E}-04$ & 0.1009 & none \\
\hline 8 & $\mathrm{SiO}_{2}$ & 0.00064 & 0.6794 & 3.93 & 1.9897E-02 & 0.3953 & none \\
\hline 9 & Co & 0.00063 & 0.6952 & 3.65 & $2.5998 \mathrm{E}-02$ & 0.2398 & none \\
\hline 10 & $\mathrm{CaO}$ & 0.00061 & 0.7110 & 3.39 & $3.3710 \mathrm{E}-02$ & 0.2979 & none \\
\hline
\end{tabular}

\begin{tabular}{|c|c|c|c|c|c|c|}
\hline \multirow{2}{*}{$\begin{array}{l}n=38 \\
\text { Element }\end{array}$} & \multicolumn{6}{|c|}{$\begin{array}{l}\text { Variables currently not in the model (fprinttraceln1) } \\
\text { Df for all F-tests: } 3,24\end{array}$} \\
\hline & Wilks' $\Lambda$ & $\begin{array}{c}\text { Wilks' } \\
\text { Partial } \Lambda\end{array}$ & $\begin{array}{l}\text { F to } \\
\text { Enter }\end{array}$ & p-level & Toler. & 1-Toler. \\
\hline $\mathrm{FeO}$ & 0.000397 & 0.9125 & 0.7675 & 0.5235 & 0.1931 & 0.8069 \\
\hline $\mathrm{Cr}$ & 0.000380 & 0.8734 & 1.1592 & 0.3458 & 0.2338 & 0.7662 \\
\hline $\mathrm{Cu}$ & 0.000399 & 0.9156 & 0.7372 & 0.5402 & 0.4438 & 0.5562 \\
\hline $\mathrm{Zn}$ & 0.000340 & 0.7820 & 2.2300 & 0.1107 & 0.3498 & 0.6502 \\
\hline
\end{tabular}




\begin{tabular}{|c|r|r|r|r|}
\hline & \multicolumn{4}{|c|}{$\begin{array}{r}\text { Squared Mahalanobis Distances } \\
\text { (fprinttraceln1) }\end{array}$} \\
\hline Category & \multicolumn{1}{|c|}{ SA } & \multicolumn{1}{|c|}{ CH } & \multicolumn{1}{c|}{ SC } & \multicolumn{1}{c|}{ L } \\
\hline SA & 0.0000 & 196.9609 & 271.7414 & 282.0565 \\
CH & 196.9609 & 0.0000 & 46.9349 & 68.1226 \\
SC & 271.7414 & 46.9349 & 0.0000 & 66.1183 \\
L & 282.0565 & 68.1226 & 66.1183 & 0.0000 \\
\hline
\end{tabular}

\begin{tabular}{|c|r|r|r|r|}
\hline & \multicolumn{5}{|c|}{ F-values; df $=10,26$ (fprinttraceln1) } \\
\hline Category & \multicolumn{1}{|c|}{ SA } & \multicolumn{1}{c|}{ CH } & \multicolumn{1}{c|}{ SC } & \multicolumn{1}{c|}{ L } \\
\hline SA & & 31.598 & 98.953 & 105.583 \\
CH & 31.598 & & 8.412 & 12.375 \\
SC & 98.953 & 8.412 & & 32.771 \\
L & 105.583 & 12.375 & 32.771 & \\
\hline
\end{tabular}

\begin{tabular}{|c|cccc|c|}
\hline \multicolumn{5}{|c|}{ p-levels (fprinttraceln1) } \\
\hline Category & SA & CH & SC & L \\
\hline SA & & $5.036 \mathrm{E}-12$ & $4.389 \mathrm{E}-18$ & $1.941 \mathrm{E}-18$ \\
CH & $5.036 \mathrm{E}-12$ & & $6.282 \mathrm{E}-06$ & $1.536 \mathrm{E}-07$ \\
SC & $4.389 \mathrm{E}-18$ & $6.282 \mathrm{E}-06$ & & $3.281 \mathrm{E}-12$ \\
L & $1.941 \mathrm{E}-18$ & $1.536 \mathrm{E}-07$ & $3.281 \mathrm{E}-12$ & \\
\hline
\end{tabular}

\begin{tabular}{|c|c|c|c|c|c|c|c|c|c|c|c|c|}
\hline & & \multicolumn{11}{|c|}{ Summary of Stepwise Analysis (fprinttraceln1) } \\
\hline $\begin{array}{r}\mathbf{V} \\
\text { Ente }\end{array}$ & $\begin{array}{l}\text { ariable } \\
\text { r/Remove }\end{array}$ & Step & $\begin{array}{c}F \text { to } \\
\text { enterl } \\
\text { remove }\end{array}$ & df 1 & df 2 & p-level & $\begin{array}{l}\text { No. of Vars. } \\
\text { In Model }\end{array}$ & Lambda & F-value & df 1 & df 2 & p-level \\
\hline $\mathrm{V}$ & $-(\mathrm{E})$ & 1 & 52.653 & 3 & 34 & $7.209 \mathrm{E}-13$ & 1 & 0.177120 & 52.653 & 3 & 34 & $7.209 \mathrm{E}-13$ \\
\hline Sm & $-(\mathrm{E})$ & 2 & 33.598 & 3 & 33 & 3.825E-10 & 2 & 0.043686 & 41.629 & 6 & 66 & $1.391 \mathrm{E}-20$ \\
\hline $\mathrm{Sc}$ & $-(E)$ & 3 & 22.999 & 3 & 32 & 3.990E-08 & 3 & 0.013841 & 41.656 & 9 & 78 & $3.281 \mathrm{E}-26$ \\
\hline $\mathrm{Ni}$ & $-(E)$ & 4 & 10.419 & 3 & 31 & 6.715E-05 & 4 & 0.006892 & 38.149 & 12 & 82 & $1.712 \mathrm{E}-28$ \\
\hline $\mathrm{Ga}$ & $-(E)$ & 5 & 8.367 & 3 & 30 & 3.428E-04 & 5 & 0.003752 & 36.411 & 15 & 83 & $3.898 \mathrm{E}-30$ \\
\hline $\mathrm{K}_{2} \mathrm{O}$ & $-(E)$ & 6 & 9.704 & 3 & 29 & 1.350E-04 & 6 & 0.001873 & 37.641 & 18 & 83 & $0.000 \mathrm{E}+00$ \\
\hline $\mathrm{Ba}$ & $-(E)$ & 7 & 6.926 & 3 & 28 & 1.245E-03 & 7 & 0.001075 & 37.817 & 21 & 81 & $0.000 \mathrm{E}+00$ \\
\hline $\mathrm{SiO}_{2}$ & $-(E)$ & 8 & 2.751 & 3 & 27 & 6.211E-02 & 8 & 0.000823 & 34.767 & 24 & 79 & $0.000 \mathrm{E}+00$ \\
\hline Co & $-(E)$ & 9 & 2.989 & 3 & 26 & 4.930E-02 & 9 & 0.000612 & 32.885 & 27 & 77 & $0.000 \mathrm{E}+00$ \\
\hline $\mathrm{CaO}$ & $-(\mathrm{E})$ & 10 & 3.387 & 3 & 25 & 3.371E-02 & 10 & 0.000435 & 32.014 & 30 & 74 & $0.000 \mathrm{E}+00$ \\
\hline
\end{tabular}

\begin{tabular}{|c|c|c|c|c|c|c|}
\cline { 2 - 7 } \multicolumn{1}{c|}{} & \multicolumn{5}{c|}{ Chi-Square Tests with Successive Roots Removed } \\
(fprinttraceln1)
\end{tabular}




\begin{tabular}{|c|rrr|rrr|}
\hline & \multicolumn{3}{|c|}{$\begin{array}{c}\text { Raw Coefficients for } \\
\text { Canonical Variables }\end{array}$} & \multicolumn{3}{c|}{$\begin{array}{c}\text { Standardized Coefficients for } \\
\text { Canonical Variables }\end{array}$} \\
\hline Variable & \multicolumn{1}{|c|}{ Root 1 } & \multicolumn{1}{c|}{ Root 2 } & \multicolumn{1}{c|}{ Root 3 } & \multicolumn{1}{|c|}{ Root 1 } & \multicolumn{1}{c|}{ Root 2 } & \multicolumn{1}{c|}{ Root 3 } \\
\hline \hline $\mathbf{V}$ & -3.8913 & -1.2663 & 2.52540 & -1.41103 & -0.45918 & 0.91575 \\
$\mathbf{S m}$ & 1.0846 & -1.4575 & 0.05126 & 1.10442 & -1.48419 & 0.05220 \\
$\mathbf{S c}$ & -5.4607 & 2.1399 & -1.63977 & -2.49940 & 0.97945 & -0.75053 \\
$\mathbf{~ N i}$ & -2.8046 & 0.3588 & 0.50912 & -2.09650 & 0.26821 & 0.38058 \\
$\mathbf{G a}$ & 0.0862 & -0.7480 & -5.86921 & 0.02502 & -0.21703 & -1.70306 \\
$\mathbf{K}_{\mathbf{2}} \mathbf{O}$ & 2.5027 & 1.1602 & 1.81737 & 1.89425 & 0.87812 & 1.37552 \\
$\mathbf{B a}$ & -2.6596 & -0.9911 & -0.89945 & -2.03836 & -0.75957 & -0.68935 \\
$\mathbf{S i O}{ }_{2}$ & -4.2602 & -13.5984 & -5.34365 & -0.26495 & -0.84572 & -0.33234 \\
$\mathbf{C o}$ & -5.3605 & -0.6265 & -0.02755 & -1.13199 & -0.13230 & -0.00582 \\
$\mathbf{C a O}$ & -0.6967 & 0.6461 & 0.07810 & -0.73666 & 0.68318 & 0.08258 \\
\hline Constant & 100.7097 & 59.9839 & 29.89091 & -- & - & -- \\
\hline \hline Eigenval & 47.3565 & 13.2340 & 2.33797 & 47.35652 & 13.23402 & 2.33797 \\
Cum.Prob & 0.7525 & 0.9628 & 1.00000 & 0.75254 & 0.96285 & 1.00000 \\
\hline \hline
\end{tabular}

\begin{tabular}{|c|c|c|c|}
\hline \multirow[b]{2}{*}{ Variable } & \multicolumn{3}{|c|}{\begin{tabular}{|l} 
Factor Structure Matrix (fprinttraceln1) \\
Correlations Variables - Canonical Roots \\
(Pooled-within-groups correlations)
\end{tabular}} \\
\hline & Root 1 & Root 2 & Root 3 \\
\hline V & -0.265650 & -0.301819 & 0.205141 \\
\hline Sm & 0.084162 & -0.461940 & 0.017361 \\
\hline Sc & -0.120982 & 0.002864 & -0.225644 \\
\hline $\mathbf{N i}$ & -0.000411 & -0.013043 & 0.270923 \\
\hline $\mathbf{G a}$ & -0.018921 & -0.068479 & -0.204791 \\
\hline $\mathrm{K}_{2} \mathrm{O}$ & 0.023647 & 0.117008 & 0.066308 \\
\hline $\mathrm{Ba}$ & -0.115295 & 0.040881 & -0.112695 \\
\hline $\mathrm{SiO}_{2}$ & -0.010777 & -0.198531 & -0.048099 \\
\hline Co & 0.041778 & 0.164090 & 0.036244 \\
\hline $\mathrm{CaO}$ & 0.008053 & -0.082343 & 0.064625 \\
\hline
\end{tabular}

\begin{tabular}{|c|c|c|c|}
\hline \multirow[b]{2}{*}{ Category } & \multicolumn{3}{|c|}{$\begin{array}{l}\text { Means of Canonical Variables } \\
\text { (fprinttraceln1) }\end{array}$} \\
\hline & Root 1 & Root 2 & Root 3 \\
\hline SA & 12.48530 & 0.33682 & -0.358611 \\
\hline $\mathrm{CH}$ & -0.40133 & -1.46090 & 4.901036 \\
\hline SC & -3.37724 & -4.13881 & -0.658425 \\
\hline $\mathbf{L}$ & -3.91245 & 3.96376 & -0.233907 \\
\hline
\end{tabular}




\begin{tabular}{|c|c|c|c|c|}
\hline \multirow[b]{2}{*}{ Samples } & \multirow[b]{2}{*}{ Group } & \multicolumn{3}{|c|}{$\begin{array}{l}\text { Unstandardized Canonical Scores } \\
\text { (fprinttraceln1) }\end{array}$} \\
\hline & & Root 1 & Root 2 & Root 3 \\
\hline SA GS-1 & SA & 11.38517 & 0.06275 & -1.35223 \\
\hline SA GS-3 & SA & 13.77015 & -1.21673 & 2.16048 \\
\hline SA GS-13 & SA & 11.59856 & -1.22209 & 0.18014 \\
\hline SA GS-17 & SA & 10.84693 & -0.26074 & 0.04967 \\
\hline SA GS-18 & SA & 10.96063 & 0.66855 & -0.33234 \\
\hline SA PVC1 & SA & 13.06462 & 3.32121 & -1.66963 \\
\hline SA PVC2 & SA & 13.25851 & 0.93341 & -1.16515 \\
\hline SA PVC3 & SA & 14.99782 & 0.40820 & -0.73982 \\
\hline CH GS-7 & $\mathrm{CH}$ & 0.49530 & -2.44887 & 3.90816 \\
\hline CH GS-12 & $\mathrm{CH}$ & -0.50687 & -0.79155 & 6.77699 \\
\hline $\mathrm{CH}$ GS-16 & $\mathrm{CH}$ & -1.19242 & -1.14229 & 4.01795 \\
\hline SC GS-11 & SC & -2.29402 & -2.72258 & 0.00284 \\
\hline SC GS-15 & SC & -2.67490 & -3.17300 & 1.04691 \\
\hline SC2 & SC & -3.89127 & -4.68218 & -1.19594 \\
\hline sc3 & SC & -1.82741 & -4.72547 & -0.27658 \\
\hline SC4 & SC & -3.31516 & -4.92198 & -1.50356 \\
\hline SC5 & SC & -4.36647 & -4.78101 & 0.36413 \\
\hline Sc6 & SC & -4.13514 & -4.71356 & -1.92307 \\
\hline SC7 & SC & -2.48276 & -4.51315 & -1.24989 \\
\hline SC8 & SC & -3.69649 & -4.19009 & -0.67063 \\
\hline Sc9 & SC & -3.08595 & -5.63920 & -2.32574 \\
\hline SC10 & SC & -4.59665 & -4.13545 & -0.98107 \\
\hline SC11 & SC & -2.68803 & -2.91241 & -0.59866 \\
\hline SC PVC5 & SC & -4.84989 & -2.69445 & 0.75174 \\
\hline L GS-2 & $\mathrm{L}$ & -3.21066 & 2.87755 & 0.50267 \\
\hline L GS-4 & L & -4.38172 & 3.00500 & -0.02110 \\
\hline L GS-10 & $\mathrm{L}$ & -4.12813 & 3.64101 & -0.37085 \\
\hline L 1A & $\mathrm{L}$ & -3.11477 & 4.79748 & -0.11592 \\
\hline$L A$ & L & -4.29443 & 5.02010 & -0.48149 \\
\hline L $3 A$ & $L$ & -4.57087 & 3.84173 & -1.39136 \\
\hline L 4A & L & -3.69845 & 4.18178 & -0.94517 \\
\hline L 5A & L & -4.78087 & 5.37838 & -0.04997 \\
\hline$L 6 A$ & L & -2.55196 & 3.29835 & -0.37827 \\
\hline L 7A & L & -3.97981 & 4.25121 & 0.62305 \\
\hline L 8A & L & -3.90601 & 3.76343 & -0.72574 \\
\hline L 9A & L & -3.52560 & 3.57936 & -0.02611 \\
\hline L10A & $L$ & -4.83719 & 3.69514 & 1.12010 \\
\hline L 11A & $\mathrm{L}$ & -3.79381 & 4.16212 & -1.01455 \\
\hline $\mathrm{P} 1$ & ---- & -5.22578 & 3.87869 & -0.84295 \\
\hline P2 & ---- & 13.31965 & 0.46538 & -1.33576 \\
\hline P3 & ---- & -3.25215 & -2.73771 & -0.70710 \\
\hline P4 & ---- & -4.51610 & 3.65506 & -0.72381 \\
\hline P5 & ---- & -4.94768 & 4.44159 & -0.39023 \\
\hline P6 & ---- & 0.07617 & 0.99367 & -0.53219 \\
\hline
\end{tabular}



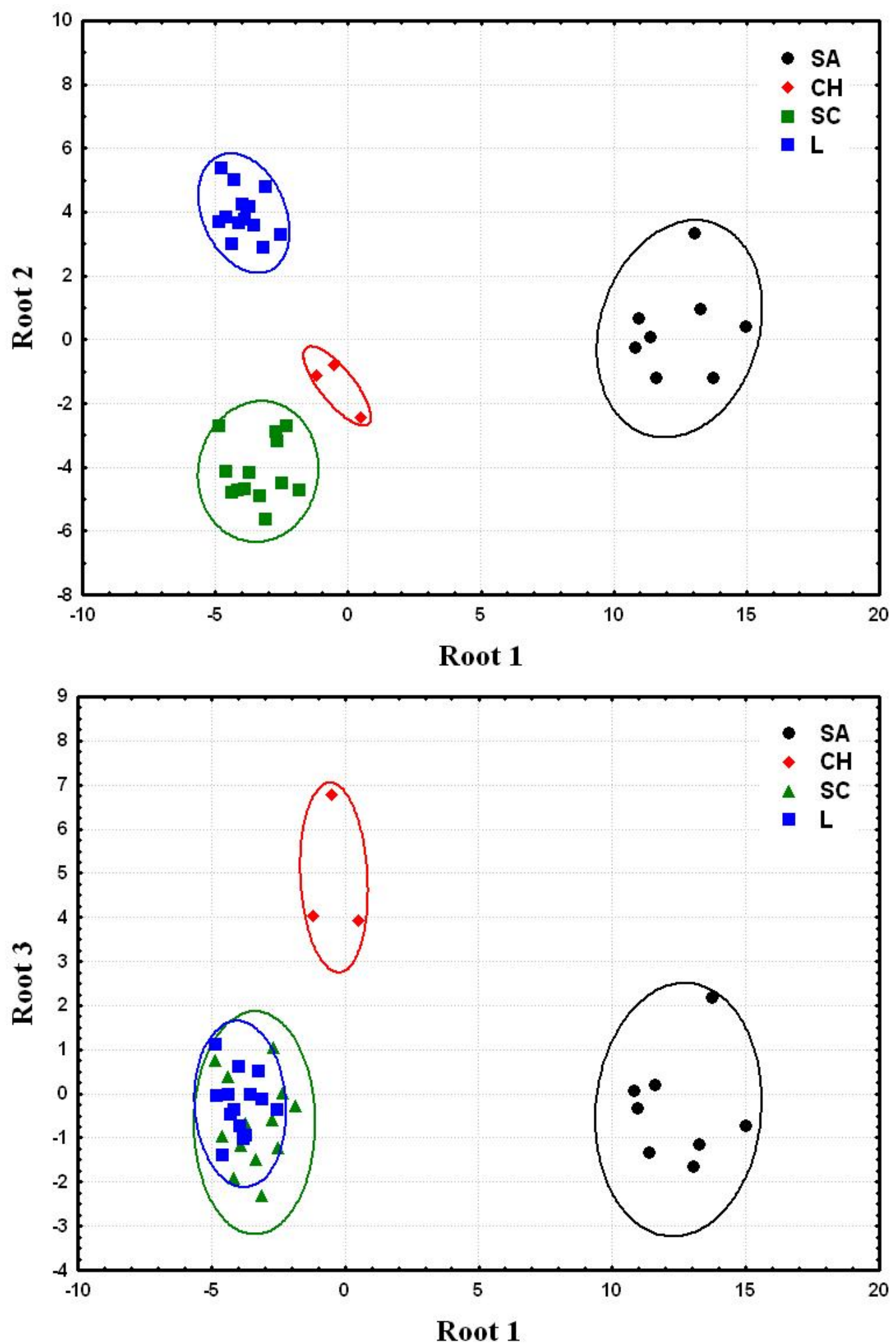


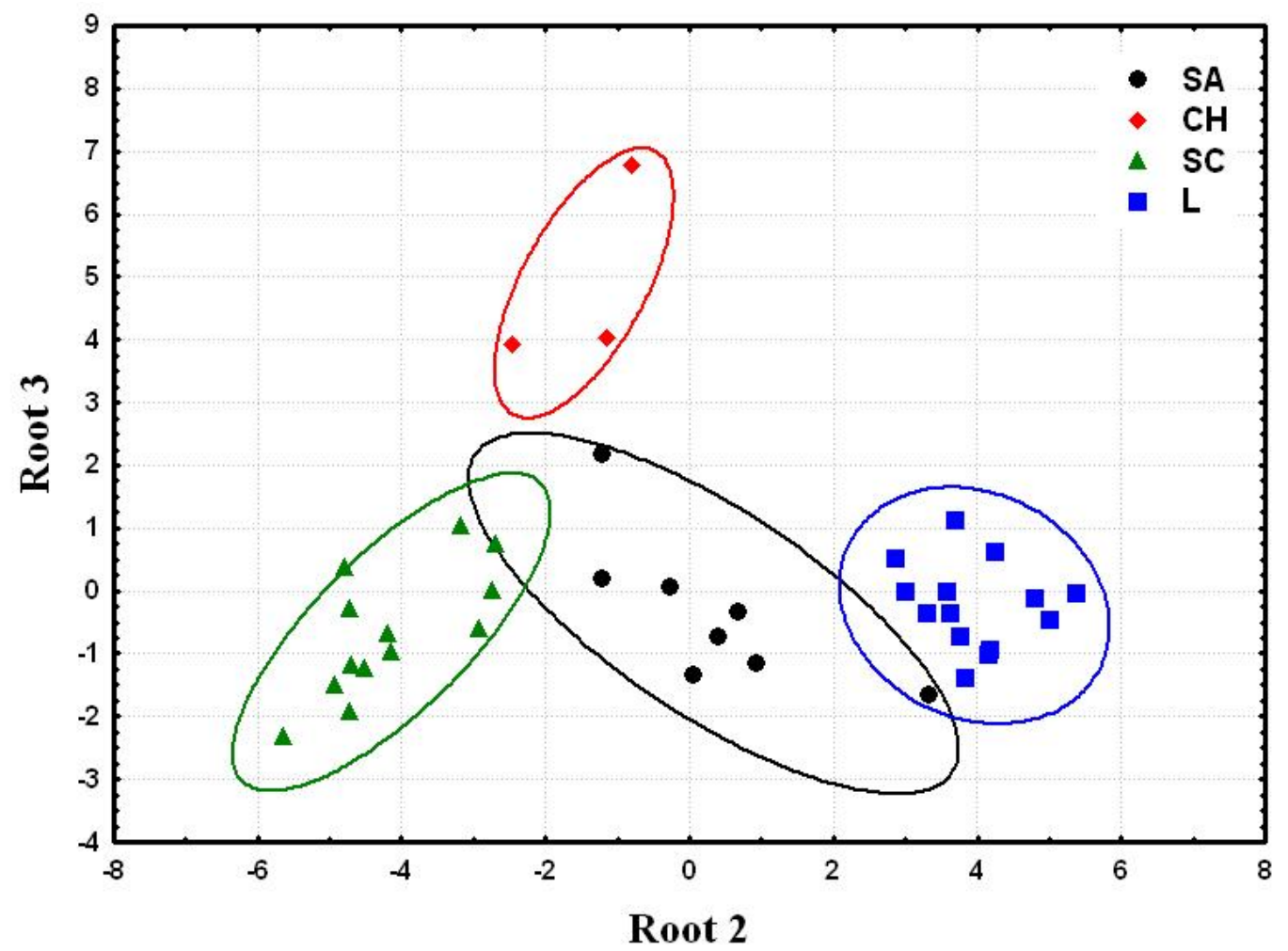




\section{Classification}

\begin{tabular}{|c|c|c|c|c|}
\hline \multirow[b]{2}{*}{ Variable } & \multicolumn{4}{|c|}{$\begin{array}{l}\text { Classification Functions; } \\
\text { grouping: Category (fprinttraceln1) }\end{array}$} \\
\hline & $\begin{array}{c}\text { SA } \\
p=.21053\end{array}$ & $\begin{array}{c}\mathrm{CH} \\
\mathrm{p}=.07895\end{array}$ & $\begin{array}{c}S C \\
p=.34211\end{array}$ & $\begin{array}{c}\mathrm{L} \\
p=.36842\end{array}$ \\
\hline $\mathbf{V}$ & 359.9 & 425.6 & 426.6 & 419.5 \\
\hline Sm & -5.5 & -16.6 & -16.2 & -28.5 \\
\hline Sc & 486.2 & 544.1 & 563.7 & 583.3 \\
\hline $\mathrm{Ni}$ & 224.5 & 262.7 & 267.2 & 271.9 \\
\hline Ga & 224.8 & 194.1 & 228.5 & 219.9 \\
\hline $\mathrm{K}_{2} \mathrm{O}$ & -237.9 & -262.7 & -283.4 & -274.6 \\
\hline $\mathrm{Ba}$ & 311.1 & 342.4 & 357.9 & 351.0 \\
\hline $\mathrm{SiO}_{2}$ & 3064.2 & 3115.5 & 3194.3 & 3084.1 \\
\hline Co & 991.0 & 1061.1 & 1078.9 & 1076.7 \\
\hline $\mathrm{CaO}$ & 22.9 & 31.1 & 31.0 & 36.7 \\
\hline Constant & -10634.1 & -11818.6 & -12444.9 & -12001.1 \\
\hline
\end{tabular}

\begin{tabular}{|c|c|c|c|c|c|}
\hline & \multicolumn{5}{|c|}{$\begin{array}{l}\text { Classification Matrix (fprinttraceln1.sta) } \\
\text { Rows: Observed classifications } \\
\text { Columns: Predicted classifications }\end{array}$} \\
\hline & $\begin{array}{l}\text { Percent } \\
\text { Correct }\end{array}$ & $\begin{array}{c}\text { SA } \\
p=.21053\end{array}$ & $\begin{array}{c}\mathrm{CH} \\
p=.07895\end{array}$ & $\begin{array}{c}S C \\
p=.34211\end{array}$ & $\begin{array}{c}L \\
p=.36842\end{array}$ \\
\hline SA & 100.00 & 8 & 0 & 0 & 0 \\
\hline $\mathrm{CH}$ & 100.00 & 0 & 3 & 0 & 0 \\
\hline SC & 100.00 & 0 & 0 & 13 & 0 \\
\hline $\mathrm{L}$ & 100.00 & 0 & 0 & 0 & 14 \\
\hline Total & 100.00 & 8 & 3 & 13 & 14 \\
\hline
\end{tabular}




\begin{tabular}{|c|c|c|c|c|c|}
\hline \multirow[b]{2}{*}{ Case } & \multirow[b]{2}{*}{$\begin{array}{l}\text { Observed } \\
\text { Classif. }\end{array}$} & \multicolumn{4}{|c|}{$\begin{array}{l}\text { Classification of Cases (fprinttraceln1) } \\
\text { Incorrect classifications are marked with * }\end{array}$} \\
\hline & & $\begin{array}{c}1 \\
p=0.21053\end{array}$ & $\begin{array}{c}2 \\
p=0.07895\end{array}$ & $\begin{array}{c}3 \\
p=0.34211\end{array}$ & $\begin{array}{c}4 \\
p=0.36842\end{array}$ \\
\hline SA GS-1 & SA & $\mathrm{SA}$ & $\mathrm{CH}$ & SC & $\mathrm{L}$ \\
\hline SA GS-3 & SA & SA & $\mathrm{CH}$ & SC & L \\
\hline SA GS-13 & SA & SA & $\mathrm{CH}$ & SC & L \\
\hline SA GS-17 & SA & SA & $\mathrm{CH}$ & SC & L \\
\hline SA GS-18 & SA & SA & $\mathrm{CH}$ & SC & L \\
\hline SA PVC1 & SA & SA & $\mathrm{CH}$ & SC & L \\
\hline SA PVC2 & SA & SA & $\mathrm{CH}$ & SC & L \\
\hline SA PVC3 & SA & SA & $\mathrm{CH}$ & SC & $\mathrm{L}$ \\
\hline CH GS-7 & $\mathrm{CH}$ & $\mathrm{CH}$ & SC & L & SA \\
\hline CH GS-12 & $\mathrm{CH}$ & $\mathrm{CH}$ & SC & $L$ & SA \\
\hline CH GS-16 & $\mathrm{CH}$ & $\mathrm{CH}$ & SC & $\mathrm{L}$ & SA \\
\hline SC GS-11 & SC & SC & $\mathrm{CH}$ & $L$ & SA \\
\hline SC GS-15 & SC & SC & $\mathrm{CH}$ & L & SA \\
\hline SC2 & SC & SC & $\mathrm{CH}$ & $\mathrm{L}$ & SA \\
\hline SC3 & SC & SC & $\mathrm{CH}$ & $L$ & SA \\
\hline SC4 & SC & SC & $\mathrm{CH}$ & L & SA \\
\hline SC5 & SC & SC & $\mathrm{CH}$ & $\mathrm{L}$ & SA \\
\hline SC6 & SC & SC & $\mathrm{CH}$ & $\mathrm{L}$ & SA \\
\hline SC7 & SC & SC & $\mathrm{CH}$ & L & SA \\
\hline SC8 & SC & SC & $\mathrm{CH}$ & L & SA \\
\hline SC9 & SC & SC & $\mathrm{CH}$ & $\mathrm{L}$ & SA \\
\hline SC10 & SC & SC & $\mathrm{CH}$ & L & SA \\
\hline SC11 & SC & SC & $\mathrm{CH}$ & L & SA \\
\hline SC PVC5 & SC & SC & $\mathrm{CH}$ & L & SA \\
\hline L GS-2 & $L$ & $L$ & $\mathrm{CH}$ & SC & SA \\
\hline L GS-4 & L & $\mathrm{L}$ & SC & $\mathrm{CH}$ & SA \\
\hline L GS-10 & $\mathrm{L}$ & $L$ & SC & $\mathrm{CH}$ & SA \\
\hline L $1 \mathrm{~A}$ & $\mathrm{~L}$ & $L$ & $\mathrm{CH}$ & SC & SA \\
\hline L A & $L$ & L & SC & $\mathrm{CH}$ & SA \\
\hline L $3 A$ & $\mathrm{~L}$ & $\mathrm{~L}$ & SC & $\mathrm{CH}$ & SA \\
\hline L 4A & $L$ & $L$ & SC & $\mathrm{CH}$ & SA \\
\hline L 5A & $\mathrm{L}$ & $L$ & SC & $\mathrm{CH}$ & SA \\
\hline L 6A & $\mathrm{L}$ & $\mathrm{L}$ & SC & $\mathrm{CH}$ & SA \\
\hline L 7A & L & $L$ & $\mathrm{CH}$ & SC & SA \\
\hline L 8A & $L$ & $L$ & SC & $\mathrm{CH}$ & SA \\
\hline L 9A & $\mathrm{L}$ & $\mathrm{L}$ & SC & $\mathrm{CH}$ & SA \\
\hline L10A & $\mathrm{L}$ & $L$ & $\mathrm{CH}$ & SC & SA \\
\hline L 11A & $\mathrm{L}$ & $\mathrm{L}$ & SC & $\mathrm{CH}$ & SA \\
\hline $\mathrm{P} 1$ & --- & $\mathrm{L}$ & SC & $\mathrm{CH}$ & SA \\
\hline P2 & --- & SA & $\mathrm{CH}$ & SC & $\mathrm{L}$ \\
\hline P3 & --- & SC & $\mathrm{CH}$ & $L$ & SA \\
\hline P4 & --- & $\mathrm{L}$ & SC & $\mathrm{CH}$ & SA \\
\hline P5 & --- & $\mathrm{L}$ & SC & $\mathrm{CH}$ & SA \\
\hline P6 & --- & $\mathrm{L}$ & SC & $\mathrm{CH}$ & SA \\
\hline
\end{tabular}




\begin{tabular}{|c|c|c|c|c|c|}
\hline \multirow[b]{2}{*}{ Case } & \multicolumn{5}{|c|}{$\begin{array}{l}\text { Squared Mahalanobis Distances from Group Centroids (fprinttraceln1) } \\
\text { Incorrect classifications are marked with * }\end{array}$} \\
\hline & $\begin{array}{l}\text { Observed } \\
\text { Classif. }\end{array}$ & $\begin{array}{c}1 \\
p=0.21053\end{array}$ & $\begin{array}{c}2 \\
p=0.07895\end{array}$ & $\begin{array}{c}3 \\
p=0.34211\end{array}$ & $\begin{array}{c}4 \\
p=0.36842\end{array}$ \\
\hline SA GS-1 & $\overline{S A}$ & 16.9700 & 195.0438 & 250.7606 & 265.1830 \\
\hline SA GS-3 & SA & 11.8906 & 209.8816 & 311.9984 & 346.7255 \\
\hline SA GS-13 & SA & 8.1718 & 171.0063 & 238.1502 & 272.3211 \\
\hline SA GS-17 & SA & 4.9162 & 153.2077 & 219.5761 & 237.4744 \\
\hline SA GS-18 & SA & 3.5377 & 162.1192 & 229.8939 & 233.1789 \\
\hline SA PVC1 & SA & 15.1546 & 251.5678 & 331.2030 & 294.8888 \\
\hline SA PVC2 & SA & 4.1219 & 231.6402 & 305.2500 & 307.4096 \\
\hline SA PVC3 & SA & 7.5382 & 273.5217 & 359.4000 & 371.5714 \\
\hline $\mathrm{CH}$ GS-7 & $\mathrm{CH}$ & 171.1337 & 4.1741 & 40.1145 & 79.1151 \\
\hline $\mathrm{CH}$ GS-12 & $\mathrm{CH}$ & 225.2874 & 8.2792 & 79.0294 & 87.6644 \\
\hline $\mathrm{CH}$ GS-16 & $\mathrm{CH}$ & 211.1628 & 4.2479 & 38.3618 & 54.2894 \\
\hline SC GS-11 & SC & 235.7968 & 37.0443 & 11.4942 & 55.2603 \\
\hline SC GS-15 & SC & 246.9409 & 25.7696 & 7.1492 & 56.9203 \\
\hline SC2 & SC & 320.2600 & 85.9058 & 27.0247 & 101.8546 \\
\hline SC3 & SC & 235.8648 & 44.8765 & 8.2697 & 85.2296 \\
\hline SC4 & SC & 283.4905 & 66.3584 & 6.2015 & 85.7952 \\
\hline SC5 & SC & 318.8942 & 55.5265 & 10.6342 & 85.2324 \\
\hline SC6 & SC & 306.9500 & 73.8467 & 5.2612 & 80.9559 \\
\hline SC7 & SC & 251.1997 & 54.3228 & 4.1304 & 77.7746 \\
\hline SC8 & SC & 286.4762 & 53.3855 & 4.1402 & 70.7581 \\
\hline Sc9 & SC & 292.7213 & 87.5667 & 15.7910 & 107.9508 \\
\hline SC10 & SC & 316.0582 & 63.2296 & 5.4675 & 70.5000 \\
\hline SC11 & SC & 262.8518 & 59.5893 & 23.9895 & 70.9208 \\
\hline SC PVC5 & SC & 316.3979 & 43.9955 & 11.7110 & 51.6496 \\
\hline L GS-2 & $\mathrm{L}$ & 258.1226 & 50.6223 & 55.1674 & 6.7772 \\
\hline L GS-4 & L & 294.4542 & 62.7401 & 55.1740 & 3.9096 \\
\hline L GS-10 & $\mathrm{L}$ & 290.9650 & 71.7523 & 65.2131 & 4.2103 \\
\hline L 1A & L & 283.8763 & 92.2576 & 100.7781 & 21.9029 \\
\hline L A & $\mathrm{L}$ & 304.5414 & 87.1649 & 85.7919 & 2.3568 \\
\hline L $3 A$ & $\mathrm{~L}$ & 314.2932 & 95.1264 & 75.6802 & 11.8173 \\
\hline L 4A & L & 283.3036 & 83.1510 & 75.6796 & 6.8613 \\
\hline L 5A & $\mathrm{L}$ & 327.1675 & 94.0028 & 96.4515 & 6.3234 \\
\hline L 6A & $\mathrm{L}$ & 247.2584 & 67.5150 & 68.4391 & 14.6828 \\
\hline L 7A & L & 289.0733 & 65.4224 & 74.0852 & 2.5090 \\
\hline L 8A & $\mathrm{L}$ & 285.1882 & 75.8738 & 67.3663 & 4.9188 \\
\hline L 9A & L & 271.1152 & 63.5837 & 64.1337 & 4.4822 \\
\hline L10A & L & 327.7320 & 74.7554 & 80.8637 & 16.9590 \\
\hline L 11A & $\mathrm{L}$ & 281.4329 & 79.4817 & 70.5659 & 2.0230 \\
\hline P1 & -- & 329.3152 & 87.6333 & 70.5848 & 4.9563 \\
\hline P2 & --- & 14.1618 & 243.3677 & 312.9378 & 322.8923 \\
\hline P3 & --- & 267.6032 & 51.5702 & 12.3427 & 55.9312 \\
\hline P4 & --- & 302.6873 & 77.2389 & 64.5413 & 3.1954 \\
\hline P5 & --- & 322.7456 & 85.4927 & 78.1479 & 3.3110 \\
\hline P6 & --- & 165.9113 & 47.2360 & 49.7475 & 36.2826 \\
\hline
\end{tabular}




\begin{tabular}{|c|c|c|c|c|c|}
\hline \multirow[b]{2}{*}{ Case } & \multirow[b]{2}{*}{$\begin{array}{l}\text { Observed } \\
\text { Classif. }\end{array}$} & \multicolumn{4}{|c|}{$\begin{array}{c}\text { Posterior Probabilities (fprinttraceln1) } \\
\text { Incorrect classifications are marked with * }\end{array}$} \\
\hline & & $\begin{array}{c}1 \\
p=0.21053\end{array}$ & $\begin{array}{c}2 \\
p=0.07895\end{array}$ & $\begin{array}{c}3 \\
p=0.34211\end{array}$ & $\begin{array}{c}4 \\
p=0.36842\end{array}$ \\
\hline SA GS-1 & $\overline{S A}$ & 1.00000 & 0.00000 & 0.00000 & 0.00000 \\
\hline SA GS-3 & SA & 1.00000 & 0.00000 & 0.00000 & 0.00000 \\
\hline SA GS-13 & SA & 1.00000 & 0.00000 & 0.00000 & 0.00000 \\
\hline SA GS-17 & SA & 1.00000 & 0.00000 & 0.00000 & 0.00000 \\
\hline SA GS-18 & SA & 1.00000 & 0.00000 & 0.00000 & 0.00000 \\
\hline SA PVC1 & SA & 1.00000 & 0.00000 & 0.00000 & 0.00000 \\
\hline SA PVC2 & SA & 1.00000 & 0.00000 & 0.00000 & 0.00000 \\
\hline SA PVC3 & SA & 1.00000 & 0.00000 & 0.00000 & 0.00000 \\
\hline CH GS-7 & $\mathrm{CH}$ & 0.00000 & 1.00000 & 0.00000 & 0.00000 \\
\hline CH GS-12 & $\mathrm{CH}$ & 0.00000 & 1.00000 & 0.00000 & 0.00000 \\
\hline CH GS-16 & $\mathrm{CH}$ & 0.00000 & 1.00000 & 0.00000 & 0.00000 \\
\hline SC GS-11 & SC & 0.00000 & 0.00000 & 1.00000 & 0.00000 \\
\hline SC GS-15 & SC & 0.00000 & 0.00002 & 0.99998 & 0.00000 \\
\hline SC2 & SC & 0.00000 & 0.00000 & 1.00000 & 0.00000 \\
\hline Sc3 & SC & 0.00000 & 0.00000 & 1.00000 & 0.00000 \\
\hline SC4 & SC & 0.00000 & 0.00000 & 1.00000 & 0.00000 \\
\hline SC5 & SC & 0.00000 & 0.00000 & 1.00000 & 0.00000 \\
\hline Sc6 & SC & 0.00000 & 0.00000 & 1.00000 & 0.00000 \\
\hline SC7 & SC & 0.00000 & 0.00000 & 1.00000 & 0.00000 \\
\hline SC8 & SC & 0.00000 & 0.00000 & 1.00000 & 0.00000 \\
\hline Sc9 & SC & 0.00000 & 0.00000 & 1.00000 & 0.00000 \\
\hline SC10 & SC & 0.00000 & 0.00000 & 1.00000 & 0.00000 \\
\hline SC11 & SC & 0.00000 & 0.00000 & 1.00000 & 0.00000 \\
\hline SC PVC5 & SC & 0.00000 & 0.00000 & 1.00000 & 0.00000 \\
\hline L GS-2 & L & 0.00000 & 0.00000 & 0.00000 & 1.00000 \\
\hline L GS-4 & $\mathrm{L}$ & 0.00000 & 0.00000 & 0.00000 & 1.00000 \\
\hline L GS-10 & $\mathrm{L}$ & 0.00000 & 0.00000 & 0.00000 & 1.00000 \\
\hline L 1A & L & 0.00000 & 0.00000 & 0.00000 & 1.00000 \\
\hline L A & $\mathrm{L}$ & 0.00000 & 0.00000 & 0.00000 & 1.00000 \\
\hline L 3A & $\mathrm{L}$ & 0.00000 & 0.00000 & 0.00000 & 1.00000 \\
\hline L 4A & $\mathrm{L}$ & 0.00000 & 0.00000 & 0.00000 & 1.00000 \\
\hline L $5 A$ & $\mathrm{~L}$ & 0.00000 & 0.00000 & 0.00000 & 1.00000 \\
\hline L 6A & L & 0.00000 & 0.00000 & 0.00000 & 1.00000 \\
\hline L 7A & $\mathrm{L}$ & 0.00000 & 0.00000 & 0.00000 & 1.00000 \\
\hline L 8A & $\mathrm{L}$ & 0.00000 & 0.00000 & 0.00000 & 1.00000 \\
\hline L 9A & $\mathrm{L}$ & 0.00000 & 0.00000 & 0.00000 & 1.00000 \\
\hline L10A & $\mathrm{L}$ & 0.00000 & 0.00000 & 0.00000 & 1.00000 \\
\hline L 11A & $\mathrm{L}$ & 0.00000 & 0.00000 & 0.00000 & 1.00000 \\
\hline$\overline{\mathrm{P} 1}$ & --- & 0.00000 & 0.00000 & 0.00000 & 1.00000 \\
\hline P2 & --- & 1.00000 & 0.00000 & 0.00000 & 0.00000 \\
\hline P3 & --- & 0.00000 & 0.00000 & 1.00000 & 0.00000 \\
\hline P4 & --- & 0.00000 & 0.00000 & 0.00000 & 1.00000 \\
\hline P5 & --- & 0.00000 & 0.00000 & 0.00000 & 1.00000 \\
\hline P6 & --- & 0.00000 & 0.00089 & 0.00110 & 0.99800 \\
\hline
\end{tabular}



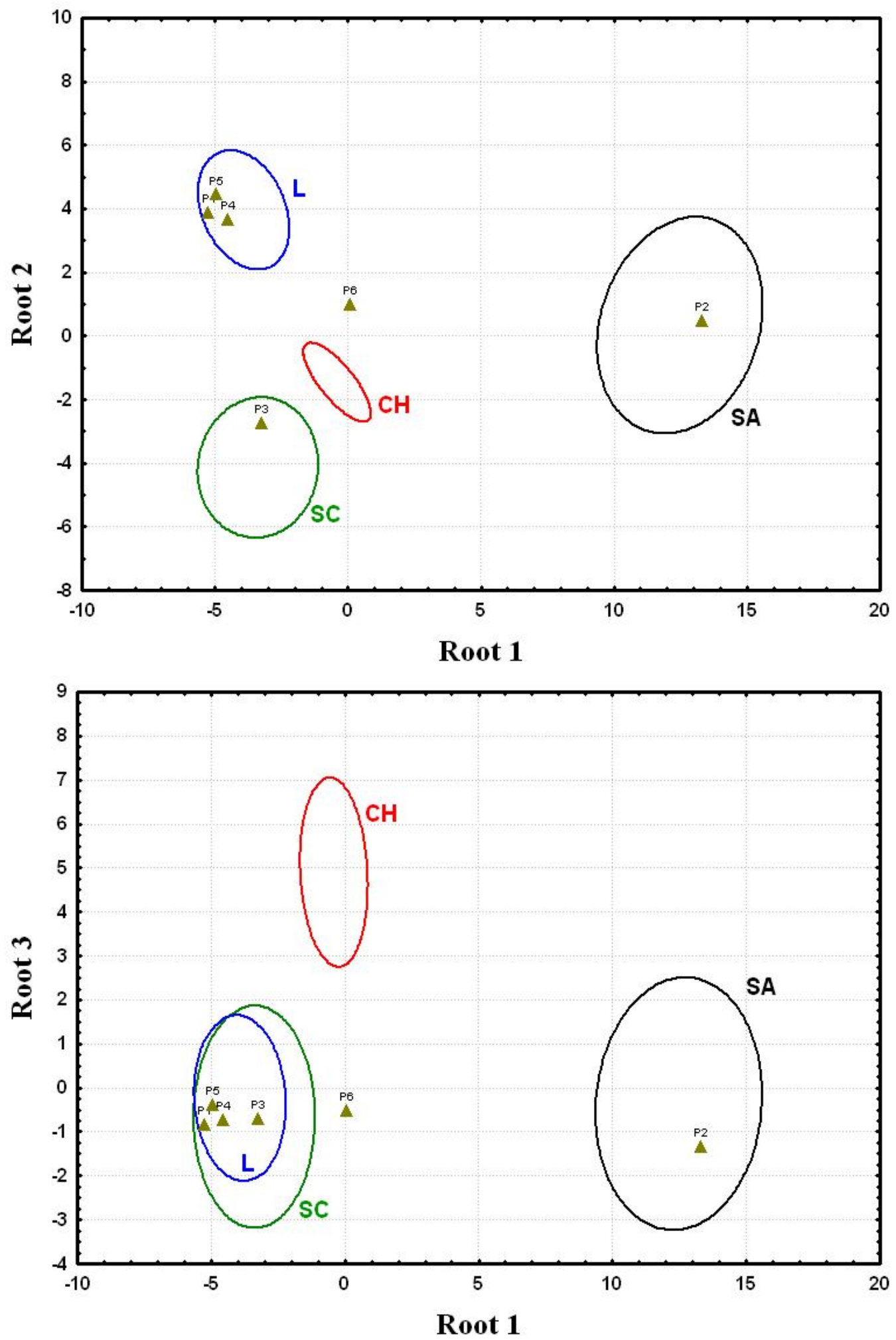


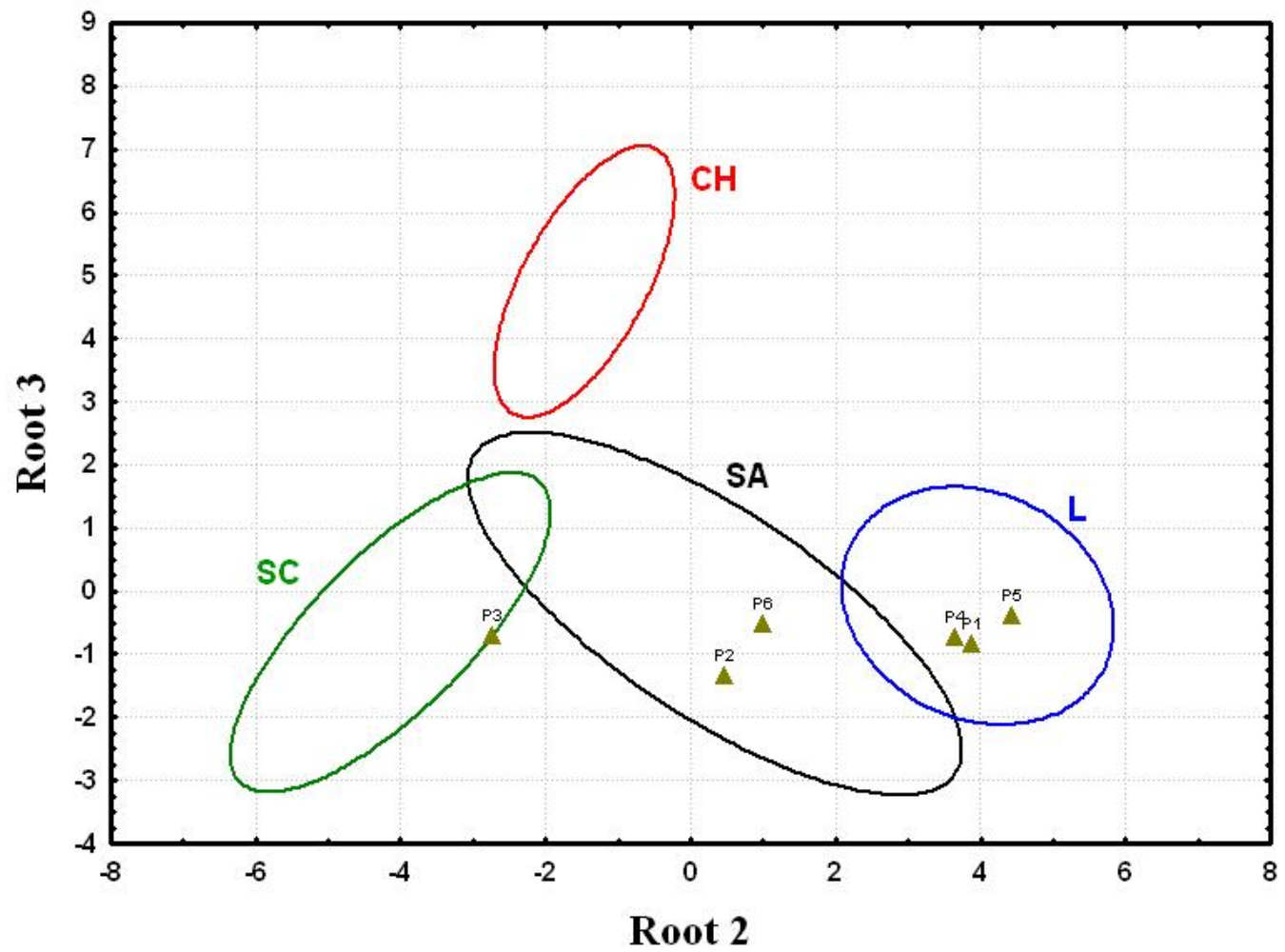




\section{Four-Category Model, Gunter Element Set}

Element Set:

$\mathrm{SiO}_{2}, \mathrm{TiO}_{2}, \mathrm{Al}_{2} \mathrm{O} 3, \mathrm{FeO}, \mathrm{MnO}, \mathrm{CaO}, \mathrm{K}_{2} \mathrm{O}, \mathrm{Ba}, \mathrm{Cr}, \mathrm{Cu}, \mathrm{Ga}, \mathrm{Ni}, \mathrm{Sc}, \mathrm{V}, \mathrm{Zn}$

\section{Categories:}

\begin{tabular}{|l|c|l|c|}
\hline \multicolumn{1}{|c|}{ Category } & Abbreviation & \multicolumn{1}{|c|}{ Sample IDs } & $\begin{array}{c}\text { No. } \\
\text { Samples }\end{array}$ \\
\hline South Africa & SA & GS-1, GS-3, GS-13, GS-17, GS-18,PVC1, PVC2, PVC3 & 8 \\
China & CH & GS-7, GS-12, GS-16 & 3 \\
South Carolina & SC & $\begin{array}{l}\text { GS-11, SG-15, SC2, SC3, SC4, SC5, SC6, SC7, SC8, } \\
\text { SC9, SC10, SC11, PVC5 }\end{array}$ & 13 \\
Libby & L & $\begin{array}{l}\text { GS-2, GS-4, GS-10, 1A, 2A, 3A, 4A, 5A, 6A, 7A, 8A, } \\
\text { 9A, 10A, 11A }\end{array}$ & 14 \\
\hline \multicolumn{2}{|c|}{ Total Number of Samples = } \\
\hline
\end{tabular}

Discriminant Function Analysis.

\begin{tabular}{|c|c|c|c|c|c|c|c|}
\hline \multirow{2}{*}{$\begin{array}{l}N=38 \\
\text { Step }\end{array}$} & \multicolumn{7}{|c|}{$\begin{array}{l}\text { Discriminant Function Analysis Summary (fprinttraceln1) } \\
\text { Step 8, N of vars in model: } 8 \text {; Grouping: Category (4 grps) } \\
\text { Wilks' Lambda: } .00198 \text { approx. F }(24,78)=24.821 \mathrm{p}<0.00\end{array}$} \\
\hline & $\begin{array}{l}\text { Element } \\
\text { Added }\end{array}$ & Wilks' $\Lambda$ & $\begin{array}{c}\text { Wilks' } \\
\text { Partial } \Lambda \\
\end{array}$ & F-Remove & p-Level & Tolerance & $\begin{array}{c}\text { Correlated Variables } \\
\text { Removed }\end{array}$ \\
\hline 1 & $\mathrm{~V}$ & 0.00542 & 0.3658 & 15.60 & 4.3979E-06 & 0.4099 & TiO2, Mno \\
\hline 2 & $\mathrm{Zn}$ & 0.00500 & 0.3966 & 13.69 & 1.2793E-05 & 0.2403 & $\mathrm{Cu}$ \\
\hline 3 & $\mathrm{SIO}_{2}$ & 0.00265 & 0.7493 & 3.01 & 4.7439E-02 & 0.2878 & none \\
\hline 4 & $\mathrm{Ga}$ & 0.00520 & 0.3811 & 14.62 & 7.5508E-06 & 0.1734 & $\mathrm{Al} 2 \mathrm{O} 3$ \\
\hline 5 & $\mathrm{Cr}$ & 0.00576 & 0.3441 & 17.16 & $1.9500 \mathrm{E}-06$ & 0.3630 & none \\
\hline 6 & $\mathrm{FeO}$ & 0.00300 & 0.6610 & 4.61 & 9.8700E-03 & 0.1390 & none \\
\hline 7 & Sc & 0.00329 & 0.6016 & 5.96 & 2.9592E-03 & 0.4186 & none \\
\hline 8 & $\mathrm{~K}_{2} \mathrm{O}$ & 0.00280 & 0.7085 & 3.70 & 2.3671E-02 & 0.3029 & none \\
\hline
\end{tabular}

\begin{tabular}{|c|c|c|c|c|c|c|}
\hline \multirow{2}{*}{$\begin{array}{l}n=38 \\
\text { Element }\end{array}$} & \multicolumn{6}{|c|}{$\begin{array}{l}\text { Variables currently not in the model (fprinttraceln1) } \\
\text { Df for all F-tests: } 3,26\end{array}$} \\
\hline & Wilks' $\Lambda$ & $\begin{array}{c}\text { Wilks' } \\
\text { Partial } \Lambda\end{array}$ & $\begin{array}{l}\text { F to } \\
\text { Enter }\end{array}$ & p-level & Toler. & 1-Toler. \\
\hline $\mathrm{CaO}$ & 0.001938 & 0.9776 & 0.1988 & 0.8962 & 0.4941 & 0.5059 \\
\hline $\mathrm{Ba}$ & 0.001464 & 0.7386 & 3.0665 & 0.0456 & 0.1442 & 0.8558 \\
\hline $\mathrm{Ni}$ & 0.001816 & 0.9164 & 0.7908 & 0.5101 & 0.2033 & 0.7967 \\
\hline
\end{tabular}




\begin{tabular}{|c|r|r|r|r|}
\hline & \multicolumn{4}{|c|}{$\begin{array}{r}\text { Squared Mahalanobis Distances } \\
\text { (fprinttraceln1) }\end{array}$} \\
\hline Category & \multicolumn{1}{|c|}{ SA } & \multicolumn{1}{|c|}{ CH } & \multicolumn{1}{c|}{ SC } & \multicolumn{1}{c|}{ L } \\
\hline SA & 0.0000 & 102.5790 & 117.4226 & 77.9210 \\
CH & 102.5790 & 0.0000 & 39.9000 & 63.8787 \\
SC & 117.4226 & 39.9000 & 0.0000 & 38.7489 \\
L & 77.9210 & 63.8787 & 38.7489 & 0.0000 \\
\hline
\end{tabular}

\begin{tabular}{|c|c|c|c|c|}
\hline & \multicolumn{4}{|c|}{ F-values; df = 8,28 (fprinttraceln1) } \\
\hline Category & SA & $\mathrm{CH}$ & SC & $\mathbf{L}$ \\
\hline SA & & 22.21631 & 57.72453 & 39.37717 \\
\hline $\mathrm{CH}$ & 22.21631 & & 9.65412 & 15.66576 \\
\hline SC & 57.72453 & 9.65412 & & 25.92757 \\
\hline $\mathbf{L}$ & 39.37717 & 15.66576 & 25.92757 & \\
\hline
\end{tabular}

\begin{tabular}{|c|c|c|c|c|}
\hline & \multicolumn{4}{|c|}{ p-levels (fprinttraceln1) } \\
\hline Category & SA & $\mathrm{CH}$ & SC & $\mathbf{L}$ \\
\hline SA & \multicolumn{4}{|c|}{$3.3858 \mathrm{E}-10$ 2.2966E-15 3.1267E-13 } \\
\hline $\mathrm{CH}$ & \multirow{2}{*}{\multicolumn{3}{|c|}{ 2.2966E-15 2.5782E-06 }} & $1.7819 \mathrm{E}-08$ \\
\hline SC & & & & $5.4161 \mathrm{E}-11$ \\
\hline $\mathbf{L}$ & \multicolumn{4}{|c|}{ 3.1267E-13 1.7819E-08 5.4161E-11 } \\
\hline
\end{tabular}

\begin{tabular}{|c|c|c|c|c|c|c|c|c|c|c|c|}
\hline & \multicolumn{11}{|c|}{ Summary of Stepwise Analysis (fprinttraceln1) } \\
\hline $\begin{array}{c}\text { Variable } \\
\text { Enter/Remove }\end{array}$ & Step & $\begin{array}{c}\mathrm{F} \text { to } \\
\text { enterl } \\
\text { remove }\end{array}$ & df 1 & df 2 & p-level & $\begin{array}{c}\text { No. of Vars. } \\
\text { In Model }\end{array}$ & Lambda & F-value & df 1 & df 2 & p-level \\
\hline $\mathrm{V}-(\mathrm{E})$ & 1 & 52.653 & 3 & 34 & $7.209 E-13$ & 1 & 0.177120 & 52.653 & 3 & 34 & $7.209 \mathrm{E}-13$ \\
\hline$Z n-(E)$ & 2 & 15.013 & 3 & 33 & $2.470 \mathrm{E}-06$ & 2 & 0.074898 & 29.194 & 6 & 66 & $8.613 \mathrm{E}-17$ \\
\hline $\mathrm{SiO}_{2}-(\mathrm{E})$ & 3 & 19.567 & 3 & 32 & 2.174E-07 & 3 & 0.026424 & 29.914 & 9 & 78 & 8.320E-22 \\
\hline Ga-(E) & 4 & 8.146 & 3 & 31 & $3.828 \mathrm{E}-04$ & 4 & 0.014776 & 26.879 & 12 & 82 & $1.735 \mathrm{E}-23$ \\
\hline $\mathrm{Cr}-(\mathrm{E})$ & 5 & 10.542 & 3 & 30 & $6.744 \mathrm{E}-05$ & 5 & 0.007193 & 27.600 & 15 & 83 & $5.342 \mathrm{E}-26$ \\
\hline $\mathrm{FeO}-(\mathrm{E})$ & 6 & 7.228 & 3 & 29 & $9.154 \mathrm{E}-04$ & 6 & 0.004116 & 27.380 & 18 & 83 & 1.797E-27 \\
\hline Sc-(E) & 7 & 4.397 & 3 & 28 & 1.177E-02 & 7 & 0.002798 & 26.011 & 21 & 81 & 1.427E-27 \\
\hline $\mathrm{K}_{2} \mathrm{O}-(\mathrm{E})$ & 8 & 3.703 & 3 & 27 & 2.367E-02 & 8 & 0.001982 & 24.821 & 24 & 79 & $1.790 \mathrm{E}-27$ \\
\hline
\end{tabular}

\begin{tabular}{|c|r|r|r|r|r|r|}
\cline { 2 - 7 } \multicolumn{1}{c|}{} & \multicolumn{5}{c|}{ Chi-Square Tests with Successive Roots Removed } \\
(fprinttraceln1) & & & \\
\hline $\begin{array}{c}\text { Roots } \\
\text { Removed }\end{array}$ & $\begin{array}{c}\text { Eigen- } \\
\text { value }\end{array}$ & $\begin{array}{c}\text { Canonical } \\
\text { R }\end{array}$ & $\begin{array}{c}\text { Wilks' } \\
\text { Lambda }\end{array}$ & Chi-Sqr. & df & p-level \\
\hline 0 & 17.368 & 0.972397 & 0.001982 & 192.9299 & 24 & $0.000 \mathrm{E}+00$ \\
1 & 7.088 & 0.936143 & 0.036408 & 102.7017 & 14 & $1.443 \mathrm{E}-15$ \\
2 & 2.396 & 0.839954 & 0.294478 & 37.8991 & 6 & $1.176 \mathrm{E}-06$ \\
\hline
\end{tabular}




\begin{tabular}{|c|rrr|rr|r|}
\hline & \multicolumn{3}{|c|}{$\begin{array}{c}\text { Raw Coefficients for } \\
\text { Canonical Variables }\end{array}$} & \multicolumn{3}{c|}{$\begin{array}{c}\text { Standardized Coefficients for } \\
\text { Canonical Variables }\end{array}$} \\
\hline Variable & \multicolumn{1}{|c|}{ Root 1 } & Root 2 & Root 3 & \multicolumn{1}{|c|}{ Root 1 } & Root 2 & \multicolumn{1}{c|}{ Root 3 } \\
\hline $\mathbf{V}$ & 3.1420 & 0.8886 & -1.5701 & 1.13933 & 0.32224 & -0.569353 \\
$\mathbf{Z n}$ & -0.2183 & 5.4974 & -1.8441 & -0.06432 & 1.61951 & -0.543257 \\
$\mathrm{SiO}_{2}$ & 9.9705 & 4.2941 & 12.7728 & 0.62010 & 0.26706 & 0.794381 \\
$\mathbf{G a}$ & -0.3122 & -1.1279 & 7.6398 & -0.09059 & -0.32729 & 2.216844 \\
$\mathbf{C r}$ & 1.1384 & -0.9852 & -0.3952 & 1.03500 & -0.89570 & -0.359268 \\
$\mathbf{F e O}$ & 3.7137 & -7.1198 & 1.3745 & 0.75631 & -1.44998 & 0.279928 \\
$\mathbf{S c}$ & 1.5325 & -1.1312 & 1.3047 & 0.70142 & -0.51774 & 0.597164 \\
$\mathbf{K}_{\mathbf{2}} \mathbf{O}$ & -0.8796 & 0.0145 & -1.1590 & -0.66576 & 0.01095 & -0.877241 \\
\hline Constant & -68.9045 & -16.5362 & -55.9869 & -- & -- & -- \\
\hline \hline Eigenval & 17.3676 & 7.0882 & 2.3958 & 17.36758 & 7.08820 & 2.395840 \\
Cum.Prob & 0.6468 & 0.9108 & 1.0000 & 0.64680 & 0.91077 & 1.000000 \\
\hline \hline
\end{tabular}

\begin{tabular}{|c|c|c|c|}
\hline \multirow[b]{2}{*}{ Variable } & \multicolumn{3}{|c|}{$\begin{array}{l}\text { Factor Structure Matrix (fprinttraceln1) } \\
\text { Correlations Variables - Canonical Roots } \\
\text { (Pooled-within-groups correlations) }\end{array}$} \\
\hline & Root 1 & Root 2 & Root 3 \\
\hline $\mathbf{V}$ & 0.510621 & 0.117634 & 0200 \\
\hline $\mathrm{Zn}$ & 0.132942 & 0.426040 & -0.004085 \\
\hline $\mathrm{SiO}_{2}$ & 0.086252 & 0.214834 & 0.178307 \\
\hline $\mathrm{Ga}$ & 0.049883 & 0.025378 & 0.232298 \\
\hline $\mathrm{Cr}$ & 0.086460 & -0.204432 & -0.196677 \\
\hline $\mathrm{FeO}$ & 0.149094 & 0.031691 & 0.018553 \\
\hline Sc & 0.177869 & -0.168057 & 0.161675 \\
\hline $\mathrm{K}_{2} \mathrm{O}$ & -0.076324 & -0.102075 & -0.133844 \\
\hline
\end{tabular}

\begin{tabular}{|c|r|r|r|}
\cline { 2 - 4 } \multicolumn{1}{c|}{} & \multicolumn{3}{c|}{$\begin{array}{c}\text { Means of Canonical Variables } \\
\text { (fprinttraceln1) }\end{array}$} \\
\hline Category & Root 1 & \multicolumn{1}{c|}{ Root 2 } & \multicolumn{1}{c|}{ Root 3 } \\
\hline SA & -7.09263 & 1.52883 & 0.55594 \\
CH & 1.43957 & 3.46738 & -4.54528 \\
SC & 3.72849 & 1.74464 & 1.08437 \\
L & 0.28228 & -3.23665 & -0.35061 \\
\hline
\end{tabular}




\begin{tabular}{|c|c|c|c|c|}
\hline \multirow{2}{*}{ Samples } & \multirow[b]{2}{*}{ Group } & \multicolumn{3}{|c|}{ Unstandardized Canonical Scores } \\
\hline & & Root 1 & Root 2 & Root 3 \\
\hline SA GS-1 & SA & -6.8691 & 2.33157 & 2.38055 \\
\hline SA GS-3 & SA & -6.1658 & 2.69496 & -1.66991 \\
\hline SA GS-13 & SA & -5.8720 & 1.41615 & 0.32302 \\
\hline SA GS-17 & SA & -5.4680 & 1.59278 & 0.67047 \\
\hline SA GS-18 & SA & -6.2442 & 1.58909 & 0.84623 \\
\hline SA PVC1 & SA & -10.0534 & 0.66692 & 0.71975 \\
\hline SA PVC2 & SA & -8.0082 & 0.78816 & 0.68410 \\
\hline SA PVC3 & SA & -8.0604 & 1.15101 & 0.49331 \\
\hline CH GS-7 & $\mathrm{CH}$ & 0.4479 & 3.83101 & -3.32757 \\
\hline CH GS-12 & $\mathrm{CH}$ & 1.6861 & 3.54792 & -6.97361 \\
\hline CH GS-16 & $\mathrm{CH}$ & 2.1847 & 3.02322 & -3.33467 \\
\hline SC GS-11 & SC & 3.4216 & 1.62454 & 0.72880 \\
\hline SC GS-15 & SC & 3.0204 & 2.10385 & -0.42831 \\
\hline $\mathrm{SC} 2$ & SC & 3.3885 & 1.90711 & 2.02638 \\
\hline SC3 & SC & 2.6183 & 1.70263 & 1.64760 \\
\hline SC4 & SC & 4.6889 & 0.87046 & 1.47019 \\
\hline SC5 & SC & 3.6269 & 2.58079 & 0.28463 \\
\hline SC6 & SC & 4.7837 & 0.78886 & 1.93148 \\
\hline SC7 & SC & 4.4059 & 2.68683 & 1.33839 \\
\hline SC8 & SC & 4.5627 & 1.62100 & 1.18345 \\
\hline Sc9 & SC & 2.5128 & 3.79450 & 2.63122 \\
\hline SC10 & SC & 4.9455 & 0.33025 & 0.83793 \\
\hline SC11 & SC & 3.8224 & 1.59912 & 1.23626 \\
\hline SC PVC5 & SC & 2.6728 & 1.07044 & -0.79116 \\
\hline L GS-2 & $\mathrm{L}$ & 1.2039 & -2.49136 & -0.62790 \\
\hline L GS-4 & L & 1.4127 & -2.22190 & -0.11227 \\
\hline L GS-10 & L & 0.9458 & -2.58119 & 0.46281 \\
\hline$L 1 A$ & $\mathrm{~L}$ & 1.0292 & -3.64762 & -0.47766 \\
\hline LA & $\mathrm{L}$ & 0.6493 & -3.91384 & -0.72750 \\
\hline$L 3 A$ & L & 0.2832 & -4.50200 & 0.76912 \\
\hline L 4A & L & -0.2016 & -3.86424 & 0.73905 \\
\hline$L 5 A$ & $\mathrm{~L}$ & -1.1407 & -3.68284 & -0.58859 \\
\hline L 6A & $\mathrm{L}$ & 0.5812 & -5.36939 & -0.73092 \\
\hline L 7A & $\mathrm{L}$ & -0.5014 & -3.94066 & -0.90610 \\
\hline L 8A & $\mathrm{L}$ & 0.0362 & -3.48799 & -0.51717 \\
\hline L $9 A$ & $\mathrm{~L}$ & 0.0617 & -3.30043 & -0.31072 \\
\hline L10A & $\mathrm{L}$ & -0.3914 & -2.00923 & -1.59197 \\
\hline L 11A & $\mathrm{L}$ & -0.0162 & -0.30047 & -0.28870 \\
\hline P1 & - & 0.2267 & -2.74608 & 0.27492 \\
\hline P2 & --- & -7.2611 & -0.07846 & 0.17481 \\
\hline P3 & ---- & 2.5951 & 2.02858 & 1.04453 \\
\hline P4 & --- & 0.1824 & -2.90728 & 0.49128 \\
\hline P5 & ---- & 0.2457 & -1.82842 & -0.29813 \\
\hline P6 & ---- & -2.9812 & -2.32754 & -0.25845 \\
\hline $\begin{array}{l}\text { Li1UI } \\
\end{array}$ & ---- & 0.7445 & -2.82027 & 1.11412 \\
\hline Li2UI & ---- & -0.3713 & -1.86869 & 0.80540 \\
\hline at1 & -.-- & 0.0384 & -1.11334 & 0.56251 \\
\hline at2UI & ---- & 0.5234 & -0.42104 & -0.05394 \\
\hline at3UI & ---- & 1.0941 & 1.86280 & -0.32419 \\
\hline at4UI & ---- & 0.1955 & -2.14112 & 2.76890 \\
\hline ga1UI & ---- & -7.0706 & 2.07781 & 1.37983 \\
\hline ga2UI & ---- & -7.3793 & 2.42123 & 1.51806 \\
\hline ga3UI & ---- & -6.4877 & 1.85108 & -0.37271 \\
\hline ga4UI & ---- & -7.5112 & 1.71044 & 0.43326 \\
\hline ga5ul & ---- & -8.9533 & 2.52884 & -4.40406 \\
\hline ga6UI & ---- & -7.1461 & 2.42040 & 0.29110 \\
\hline ga7UI & ---- & -7.9248 & 1.50284 & 2.10292 \\
\hline SA1UI & ---- & -15.6962 & -0.95550 & 6.50161 \\
\hline SC1UI & ---- & 3.0122 & 0.94970 & 1.18751 \\
\hline SC2UI & ---- & 2.5889 & 1.86007 & 1.10042 \\
\hline SC3UI & ---- & 1.6612 & 1.88958 & -0.10643 \\
\hline SC4UI & ---- & 3.3381 & 0.95770 & 1.08347 \\
\hline SC5UI & --- & 2.9061 & 3.38219 & 8.42554 \\
\hline SC6UI & ---- & 7.7752 & 0.06021 & 2.64416 \\
\hline
\end{tabular}



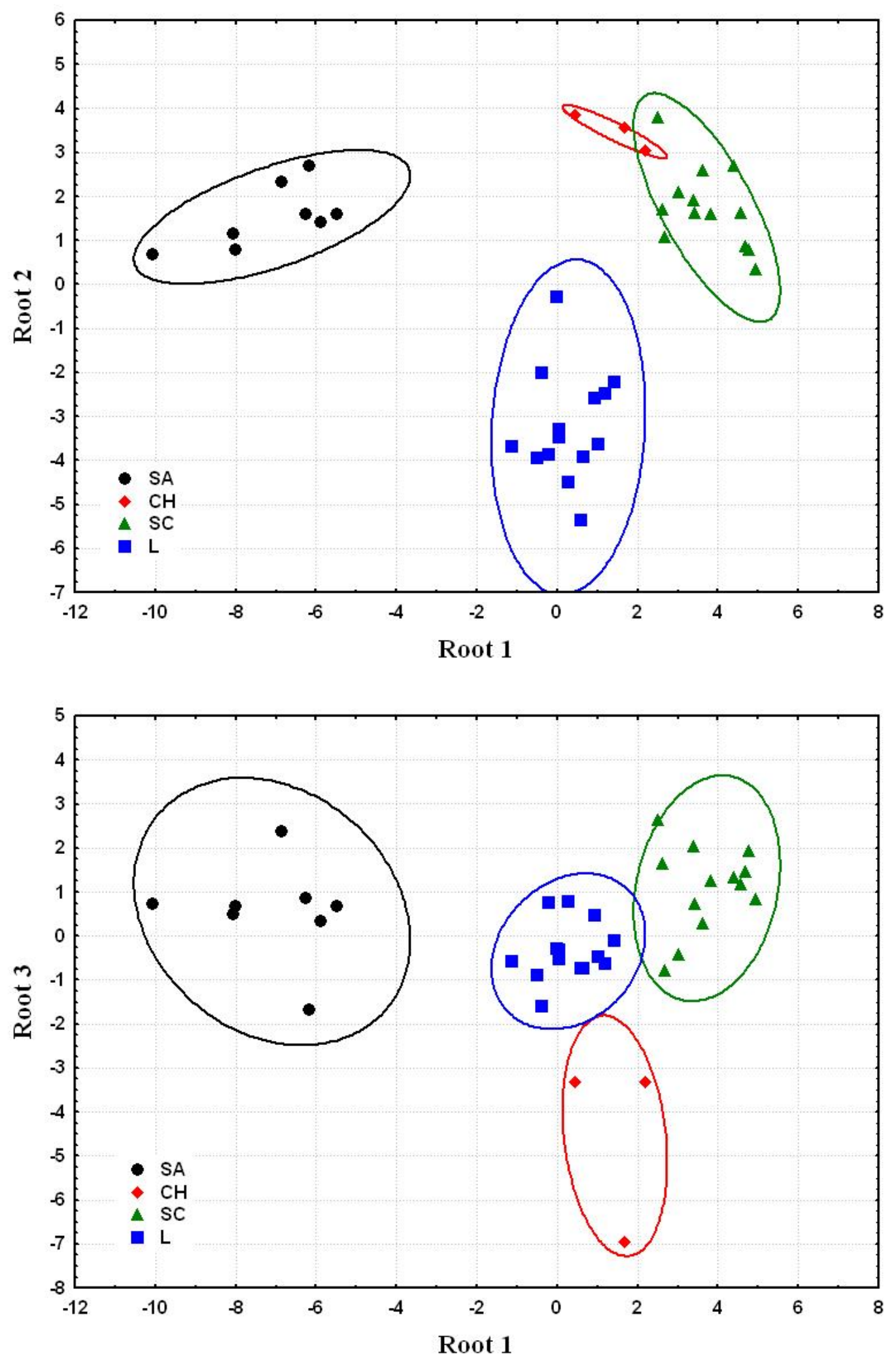


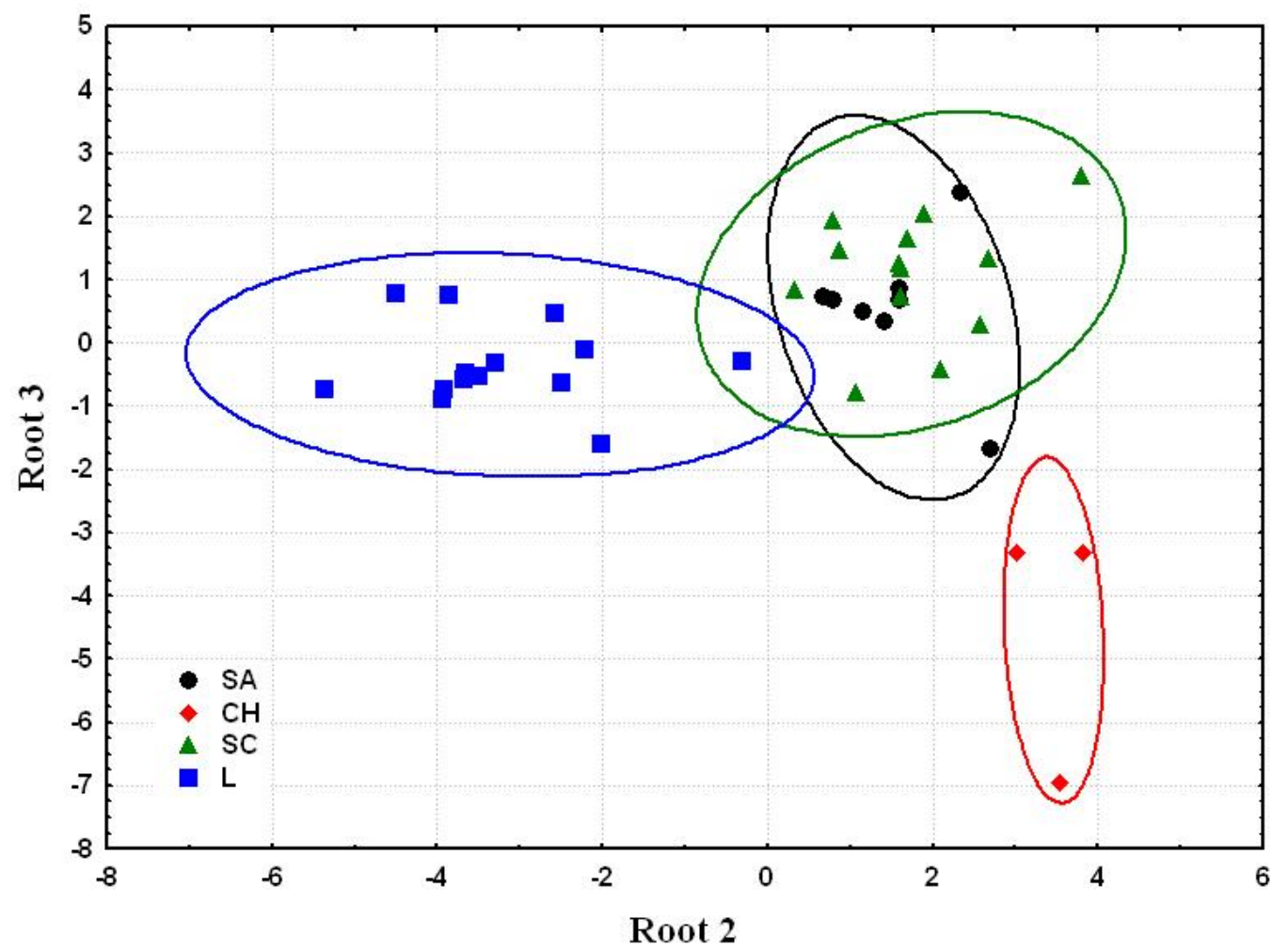




\begin{tabular}{|c|c|c|c|c|}
\hline & \multicolumn{4}{|c|}{$\begin{array}{l}\text { Classification Functions; } \\
\text { grouping: Category (fprinttraceln1) }\end{array}$} \\
\hline Variable & $\begin{array}{c}\text { SA } \\
p=.21053\end{array}$ & $\begin{array}{c}\mathrm{CH} \\
p=.07895\end{array}$ & $\begin{array}{c}\text { SC } \\
p=.34211\end{array}$ & $\begin{array}{c}\mathrm{L} \\
\mathrm{p}=.36842\end{array}$ \\
\hline $\mathbf{V}$ & 2.35 & 38.89 & 35.71 & 22.71 \\
\hline $\mathrm{Zn}$ & -154.45 & -136.25 & -156.60 & -180.59 \\
\hline $\mathrm{SiO}_{2}$ & 3865.52 & 3893.76 & 3981.09 & 3907.01 \\
\hline Ga & 227.17 & 183.35 & 227.59 & 223.32 \\
\hline $\mathrm{Cr}$ & 56.55 & 66.37 & 68.45 & 70.00 \\
\hline $\mathrm{FeO}$ & 1049.38 & 1060.25 & 1088.76 & 1109.45 \\
\hline Sc & 116.90 & 121.13 & 133.93 & 132.41 \\
\hline $\mathrm{K}_{2} \mathrm{O}$ & 41.94 & 40.38 & 31.82 & 36.44 \\
\hline Constant & -8689.72 & -9015.97 & -9450.60 & -9046.63 \\
\hline
\end{tabular}

\begin{tabular}{|c|c|c|c|c|c|}
\hline \multirow[b]{2}{*}{ Category } & \multicolumn{5}{|c|}{$\begin{array}{l}\text { Classification Matrix (fprinttraceln1.sta) } \\
\text { Rows: Observed classifications } \\
\text { Columns: Predicted classifications }\end{array}$} \\
\hline & $\begin{array}{l}\text { Percent } \\
\text { Correct }\end{array}$ & $\begin{aligned} \text { SA } \\
p=.21053\end{aligned}$ & $\begin{array}{c}\mathrm{CH} \\
p=.07895\end{array}$ & $\begin{array}{l}\text { SC } \\
p=.34211\end{array}$ & $p=.36842$ \\
\hline SA & 100.00 & 8 & 0 & 0 & 0 \\
\hline $\mathrm{CH}$ & 100.00 & 0 & 3 & 0 & 0 \\
\hline SC & 100.00 & 0 & 0 & 13 & 0 \\
\hline $\mathbf{L}$ & 100.00 & 0 & 0 & 0 & 14 \\
\hline Total & 100.00 & 8 & 3 & 13 & 14 \\
\hline
\end{tabular}




\begin{tabular}{|c|c|c|c|c|c|}
\hline \multirow[b]{2}{*}{ Case } & \multirow[b]{2}{*}{$\begin{array}{c}\text { Observed } \\
\text { Classif. }\end{array}$} & \multicolumn{4}{|c|}{$\begin{array}{l}\text { Classification of Cases (fprinttraceln1) } \\
\text { Incorrect classifications are marked with * }\end{array}$} \\
\hline & & $\begin{array}{c}1 \\
p=0.21053\end{array}$ & $\begin{array}{c}2 \\
p=0.07895\end{array}$ & $\begin{array}{c}3 \\
p=0.34211\end{array}$ & $\begin{array}{c}4 \\
p=0.36842\end{array}$ \\
\hline SA GS-1 & SA & SA & $\mathrm{L}$ & SC & $\mathrm{CH}$ \\
\hline SA GS-3 & SA & SA & $\mathrm{CH}$ & $\mathrm{L}$ & SC \\
\hline SA GS-13 & SA & SA & L & $\mathrm{CH}$ & SC \\
\hline SA GS-17 & SA & SA & L & $\mathrm{CH}$ & SC \\
\hline SA GS-18 & SA & SA & L & $\mathrm{CH}$ & SC \\
\hline SA PVC1 & SA & SA & L & $\mathrm{CH}$ & $\mathrm{SC}$ \\
\hline SA PVC2 & SA & SA & L & $\mathrm{CH}$ & $\mathrm{SC}$ \\
\hline SA PVC3 & SA & SA & $L$ & $\mathrm{CH}$ & SC \\
\hline CH GS-7 & $\mathrm{CH}$ & $\mathrm{CH}$ & SC & $L$ & SA \\
\hline CH GS-12 & $\mathrm{CH}$ & $\mathrm{CH}$ & SC & $\mathrm{L}$ & SA \\
\hline CH GS-16 & $\mathrm{CH}$ & $\mathrm{CH}$ & SC & L & SA \\
\hline SC GS-11 & SC & SC & $\mathrm{L}$ & $\mathrm{CH}$ & SA \\
\hline SC GS-15 & SC & SC & $\mathrm{CH}$ & $\mathrm{L}$ & SA \\
\hline SC2 & SC & SC & $L$ & $\mathrm{CH}$ & SA \\
\hline SC3 & SC & SC & L & $\mathrm{CH}$ & SA \\
\hline SC4 & SC & SC & L & $\mathrm{CH}$ & SA \\
\hline SC5 & SC & $\mathrm{SC}$ & $\mathrm{CH}$ & L & SA \\
\hline SC6 & SC & SC & $\mathrm{L}$ & $\mathrm{CH}$ & SA \\
\hline SC7 & SC & SC & $\mathrm{CH}$ & $\mathrm{L}$ & SA \\
\hline SC8 & $\mathrm{SC}$ & SC & L & $\mathrm{CH}$ & SA \\
\hline Sc9 & SC & SC & $\mathrm{CH}$ & $\mathrm{L}$ & SA \\
\hline SC10 & $\mathrm{SC}$ & $\mathrm{SC}$ & L & $\mathrm{CH}$ & SA \\
\hline SC11 & SC & SC & L & $\mathrm{CH}$ & SA \\
\hline SC PVC5 & SC & SC & $\mathrm{CH}$ & $\mathrm{L}$ & SA \\
\hline L GS-2 & $\mathrm{L}$ & $L$ & SC & $\mathrm{CH}$ & SA \\
\hline L GS-4 & L & L & SC & $\mathrm{CH}$ & SA \\
\hline L GS-10 & L & L & SC & $\mathrm{CH}$ & SA \\
\hline L $1 \mathrm{~A}$ & L & L & SC & $\mathrm{CH}$ & SA \\
\hline L A & L & L & SC & $\mathrm{CH}$ & SA \\
\hline L 3A & $\mathrm{L}$ & L & SC & SA & $\mathrm{CH}$ \\
\hline L 4A & L & L & SC & SA & $\mathrm{CH}$ \\
\hline L 5A & L & L & SC & SA & $\mathrm{CH}$ \\
\hline L 6A & L & L & SC & $\mathrm{CH}$ & SA \\
\hline L 7A & L & L & SC & $\mathrm{CH}$ & SA \\
\hline L 8A & L & L & SC & $\mathrm{CH}$ & SA \\
\hline L 9A & L & L & SC & $\mathrm{CH}$ & SA \\
\hline L10A & L & L & SC & $\mathrm{CH}$ & SA \\
\hline$L 11 \mathrm{~A}$ & $\mathrm{~L}$ & $\mathrm{~L}$ & $\mathrm{SC}$ & $\mathrm{CH}$ & SA \\
\hline $\mathrm{P} 1$ & ---- & L & SC & $\mathrm{CH}$ & SA \\
\hline P2 & ---- & SA & $L$ & $\mathrm{CH}$ & SC \\
\hline P3 & ---- & SC & L & $\mathrm{CH}$ & SA \\
\hline P4 & ---- & $L$ & SC & $\mathrm{CH}$ & SA \\
\hline P5 & --- & L & SC & $\mathrm{CH}$ & SA \\
\hline P6 & ---- & $\mathrm{L}$ & SA & SC & $\mathrm{CH}$ \\
\hline Li1UI & ---- & L & SC & $\mathrm{CH}$ & SA \\
\hline Li2UI & ---- & L & SC & SA & $\mathrm{CH}$ \\
\hline at1UI & ---- & L & SC & $\mathrm{CH}$ & SA \\
\hline at2UI & ---- & L & SC & $\mathrm{CH}$ & SA \\
\hline at3UI & ---- & SC & $\mathrm{CH}$ & $\mathrm{L}$ & SA \\
\hline at4UI & --- & $\mathrm{L}$ & $\mathrm{SC}$ & SA & $\mathrm{CH}$ \\
\hline ga1UI & ---- & SA & $L$ & $\mathrm{CH}$ & SC \\
\hline ga2UI & ---- & SA & L & $\mathrm{CH}$ & SC \\
\hline ga3UI & ---- & SA & L & $\mathrm{CH}$ & SC \\
\hline ga4UI & ---- & SA & L & $\mathrm{CH}$ & SC \\
\hline ga5Ul & --- & SA & $\mathrm{CH}$ & $\mathrm{L}$ & SC \\
\hline ga6Ul & --- & SA & L & $\mathrm{CH}$ & SC \\
\hline ga7UI & ---- & SA & $\mathrm{L}$ & SC & $\mathrm{CH}$ \\
\hline SA1UI & ---- & SA & $\mathrm{CH}$ & $\mathrm{SC}$ & L \\
\hline SC1UI & --- & SC & $\mathrm{L}$ & $\mathrm{CH}$ & SA \\
\hline SC2UI & ---- & SC & $L$ & $\mathrm{CH}$ & SA \\
\hline SC3UI & ---- & SC & $\mathrm{CH}$ & $\mathrm{L}$ & SA \\
\hline SC4UI & ---- & SC & L & $\mathrm{CH}$ & SA \\
\hline SC5UI & ---- & SC & L & SA & $\mathrm{CH}$ \\
\hline SC6UI & --- & SC & $\mathrm{L}$ & $\mathrm{CH}$ & SA \\
\hline
\end{tabular}




\begin{tabular}{|c|c|c|c|c|c|}
\hline \multirow[b]{2}{*}{ Case } & \multirow[b]{2}{*}{$\begin{array}{c}\text { Observed } \\
\text { Classif. }\end{array}$} & \multicolumn{4}{|c|}{$\begin{array}{l}\text { Classification of Cases (fprinttraceln1) } \\
\text { Incorrect classifications are marked with * }\end{array}$} \\
\hline & & $\begin{array}{c}1 \\
p=0.21053\end{array}$ & $\begin{array}{c}2 \\
p=0.07895\end{array}$ & $\begin{array}{c}3 \\
p=0.34211\end{array}$ & $\begin{array}{c}4 \\
p=0.36842\end{array}$ \\
\hline SA GS-1 & SA & 11.1117 & 125.3794 & 121.4217 & 96.6947 \\
\hline SA GS-3 & SA & 8.3850 & 67.9171 & 107.5970 & 79.7133 \\
\hline SA GS-13 & SA & 2.7725 & 82.5833 & 94.0735 & 61.1936 \\
\hline SA GS-17 & SA & 3.0235 & 78.7991 & 85.1361 & 57.7981 \\
\hline SA GS-18 & SA & 1.1484 & 91.9767 & 99.8753 & 67.6551 \\
\hline SA PVC1 & SA & 9.8663 & 167.9820 & 191.5654 & 123.5401 \\
\hline SA PVC2 & SA & 3.7948 & 126.1767 & 141.2167 & 88.3934 \\
\hline SA PVC3 & SA & 2.8505 & 122.7704 & 141.4478 & 91.3319 \\
\hline CH GS-7 & $\mathrm{CH}$ & 81.4099 & 6.7667 & 38.7485 & 63.0099 \\
\hline CH GS-12 & $\mathrm{CH}$ & 142.3667 & 10.4934 & 76.8835 & 96.3946 \\
\hline CH GS-16 & $\mathrm{CH}$ & 104.1872 & 2.9667 & 24.2947 & 52.4585 \\
\hline SC GS-11 & SC & 115.7849 & 40.3367 & 5.4312 & 39.8480 \\
\hline SC GS-15 & SC & 110.0448 & 27.7790 & 9.3897 & 42.4956 \\
\hline SC2 & SC & 137.7911 & 75.0506 & 26.6603 & 67.3881 \\
\hline SC3 & SC & 100.6208 & 47.9525 & 6.6486 & 38.9433 \\
\hline SC4 & SC & 140.8570 & 54.2716 & 2.6192 & 40.3856 \\
\hline SC5 & SC & 119.2895 & 32.0986 & 4.5490 & 48.6329 \\
\hline SC6 & SC & 144.0491 & 60.8686 & 3.3072 & 42.2379 \\
\hline SC7 & SC & 143.0818 & 52.9384 & 10.3236 & 63.8570 \\
\hline SC8 & SC & 143.0960 & 52.8292 & 7.5690 & 51.1198 \\
\hline SC9 & SC & 105.9211 & 56.9778 & 12.2894 & 67.5205 \\
\hline SC10 & SC & 147.4364 & 52.1159 & 4.5461 & 36.8848 \\
\hline SC11 & SC & 139.6550 & 62.6446 & 20.1034 & 58.4854 \\
\hline SC PVC5 & $\mathrm{SC}$ & 98.6788 & 22.6492 & 6.3760 & 25.7494 \\
\hline L GS-2 & L & 89.2079 & 53.7196 & 30.0607 & 4.2934 \\
\hline L GS-4 & L & 87.9762 & 53.1415 & 23.6497 & 3.4857 \\
\hline L GS-10 & L & 83.1192 & 63.5124 & 28.4451 & 3.1338 \\
\hline L 1A & L & 110.6936 & 84.2032 & 55.6687 & 17.6088 \\
\hline$L A$ & L & 93.1076 & 71.5831 & 46.6834 & 2.6359 \\
\hline$L 3 A$ & L & 95.8384 & 98.1095 & 56.0082 & 7.8734 \\
\hline L 4A & L & 80.1615 & 87.9270 & 0.5813 & 5.3720 \\
\hline L 5A & L & 65.6302 & 75.1713 & 57.6976 & 4.0131 \\
\hline L 6A & L & 110.0684 & 95.3134 & 65.7487 & 6.7213 \\
\hline L 7A & L & 76.0780 & 72.4708 & 54.7573 & 1.9990 \\
\hline L $8 A$ & L & 80.6614 & 70.0934 & 47.0994 & 3.6725 \\
\hline L 9A & L & 77.4773 & 67.8541 & 43.0653 & 2.2749 \\
\hline L10A & L & 72.1252 & 52.1556 & 48.3158 & 13.5891 \\
\hline L 11A & L & 57.7561 & 38.0551 & 23.7113 & 12.3347 \\
\hline$\overline{\mathrm{P} 1}$ & $-\overline{---}$ & 72.9457 & 64.3315 & 34.1033 & 1.6540 \\
\hline P2 & ---- & 12.0333 & 119.8296 & 134.1975 & 76.4284 \\
\hline P3 & ---- & 103.5883 & 43.8990 & 10.6143 & 44.2659 \\
\hline P4 & ---- & 73.7223 & 68.6969 & 35.6801 & 1.9403 \\
\hline P5 & --- & 67.3673 & 49.0251 & 28.3240 & 3.5031 \\
\hline P6 & --- & 48.2126 & 87.2758 & 79.1804 & 27.2596 \\
\hline Li1UI & --- & 92.0576 & 83.4579 & 41.1551 & 13.9438 \\
\hline Li2UI & --- & 67.1427 & 70.7435 & 40.3028 & 13.9955 \\
\hline at1UI & --- & 64.4927 & 55.6954 & 28.7167 & 12.0614 \\
\hline at2UI & --- & 76.7734 & 50.7261 & 30.8531 & 22.6687 \\
\hline at3UI & --- & 83.9088 & 36.5117 & 24.9381 & 42.6642 \\
\hline at4UI & --- & 75.9851 & 91.0034 & 34.9221 & 15.4421 \\
\hline ga1UI & --- & 13.3154 & 121.7965 & 129.1545 & 97.6383 \\
\hline ga2UI & --- & 8.3196 & 122.1456 & 130.5433 & 100.7181 \\
\hline ga3UI & --- & 8.6169 & 90.1484 & 113.7889 & 79.0022 \\
\hline ga4UI & --- & 21.6859 & 129.4524 & 148.2193 & 107.2897 \\
\hline ga5UI & --- & 122.6431 & 202.4916 & 285.1446 & 228.5462 \\
\hline ga6Ul & ---- & 4.6190 & 101.9510 & 123.0930 & 91.3454 \\
\hline ga7UI & ---- & 11.0538 & 143.7163 & 144.8618 & 103.8056 \\
\hline SA1UI & ---- & 153.2063 & 472.8933 & 451.6190 & 345.1311 \\
\hline SC1UI & --- & 119.9616 & 58.7965 & 18.2754 & 44.4636 \\
\hline SC2UI & ---- & 107.5166 & 49.1569 & 14.6909 & 46.7811 \\
\hline SC3UI & ---- & 78.6327 & 23.6763 & 7.1471 & 29.6737 \\
\hline SC4UI & --- & 111.6998 & 43.8807 & 3.0666 & 31.2822 \\
\hline SC5UI & --- & 171.7661 & 176.8258 & 63.6761 & 134.1399 \\
\hline SC6UI & ---- & 266.5673 & 142.4352 & 60.6444 & 114.9799 \\
\hline
\end{tabular}




\begin{tabular}{|c|c|c|c|c|c|}
\hline \multirow[b]{2}{*}{ Case } & \multirow[b]{2}{*}{$\begin{array}{l}\text { Observed } \\
\text { Classif. }\end{array}$} & \multicolumn{4}{|c|}{$\begin{array}{l}\text { Classification of Cases (fprinttraceln1) } \\
\text { Incorrect classifications are marked with * }\end{array}$} \\
\hline & & $\begin{array}{c}1 \\
p=0.21053 \\
\end{array}$ & $\begin{array}{c}2 \\
p=0.07895 \\
\end{array}$ & $\begin{array}{c}3 \\
p=0.34211\end{array}$ & $\begin{array}{c}4 \\
p=0.36842 \\
\end{array}$ \\
\hline SA GS-1 & SA & 1.00000 & 0.00000 & 0.00000 & 0.00000 \\
\hline SA GS-3 & SA & 1.00000 & 0.00000 & 0.00000 & 0.00000 \\
\hline SA GS-13 & SA & 1.00000 & 0.00000 & 0.00000 & 0.00000 \\
\hline SA GS-17 & SA & 1.00000 & 0.00000 & 0.00000 & 0.00000 \\
\hline SA GS-18 & SA & 1.00000 & 0.00000 & 0.00000 & 0.00000 \\
\hline SA PVC1 & SA & 1.00000 & 0.00000 & 0.00000 & 0.00000 \\
\hline SA PVC2 & SA & 1.00000 & 0.00000 & 0.00000 & 0.00000 \\
\hline SA PVC3 & SA & 1.00000 & 0.00000 & 0.00000 & 0.00000 \\
\hline CH GS-7 & $\mathrm{CH}$ & 0.00000 & 1.00000 & 0.00000 & 0.00000 \\
\hline $\mathrm{CH}$ GS-12 & $\mathrm{CH}$ & 0.00000 & 1.00000 & 0.00000 & 0.00000 \\
\hline $\mathrm{CH}$ GS-16 & $\mathrm{CH}$ & 0.00000 & 0.99990 & 0.00010 & 0.00000 \\
\hline SC GS-11 & SC & 0.00000 & 0.00000 & 1.00000 & 0.00000 \\
\hline SC GS-15 & $\mathrm{SC}$ & 0.00000 & 0.00002 & 0.99998 & 0.00000 \\
\hline $\mathrm{SC} 2$ & SC & 0.00000 & 0.00000 & 1.00000 & 0.00000 \\
\hline SC3 & SC & 0.00000 & 0.00000 & 1.00000 & 0.00000 \\
\hline SC4 & SC & 0.00000 & 0.00000 & 1.00000 & 0.00000 \\
\hline SC5 & SC & 0.00000 & 0.00000 & 1.00000 & 0.00000 \\
\hline SC6 & SC & 0.00000 & 0.00000 & 1.00000 & 0.00000 \\
\hline SC7 & SC & 0.00000 & 0.00000 & 1.00000 & 0.00000 \\
\hline SC8 & SC & 0.00000 & 0.00000 & 1.00000 & 0.00000 \\
\hline SC9 & SC & 0.00000 & 0.00000 & 1.00000 & 0.00000 \\
\hline SC10 & SC & 0.00000 & 0.00000 & 1.00000 & 0.00000 \\
\hline SC11 & SC & 0.00000 & 0.00000 & 1.00000 & 0.00000 \\
\hline SC PVC5 & SC & 0.00000 & 0.00007 & 0.99987 & 0.00007 \\
\hline L GS-2 & $\mathrm{L}$ & 0.00000 & 0.00000 & 0.00000 & 1.00000 \\
\hline L GS-4 & L & 0.00000 & 0.00000 & 0.00004 & 0.99996 \\
\hline L GS-10 & L & 0.00000 & 0.00000 & 0.00000 & 1.00000 \\
\hline L $1 \mathrm{~A}$ & L & 0.00000 & 0.00000 & 0.00000 & 1.00000 \\
\hline L A & L & 0.00000 & 0.00000 & 0.00000 & 1.00000 \\
\hline L $3 A$ & L & 0.00000 & 0.00000 & 0.00000 & 1.00000 \\
\hline L 4A & L & 0.00000 & 0.00000 & 0.00000 & 1.00000 \\
\hline L 5A & L & 0.00000 & 0.00000 & 0.00000 & 1.00000 \\
\hline L 6A & L & 0.00000 & 0.00000 & 0.00000 & 1.00000 \\
\hline L 7A & L & 0.00000 & 0.00000 & 0.00000 & 1.00000 \\
\hline L 8A & L & 0.00000 & 0.00000 & 0.00000 & 1.00000 \\
\hline L 9A & L & 0.00000 & 0.00000 & 0.00000 & 1.00000 \\
\hline L10A & L & 0.00000 & 0.00000 & 0.00000 & 1.00000 \\
\hline L 11A & L & 0.00000 & 0.00000 & 0.00313 & 0.99687 \\
\hline P1 & - & 0.00000 & 0.00000 & 0.00000 & 1.00000 \\
\hline P2 & ---- & 1.00000 & 0.00000 & 0.00000 & 0.00000 \\
\hline P3 & ---- & 0.00000 & 0.00000 & 1.00000 & 0.00000 \\
\hline P4 & ---- & 0.00000 & 0.00000 & 0.00000 & 1.00000 \\
\hline P5 & ---- & 0.00000 & 0.00000 & 0.00000 & 1.00000 \\
\hline P6 & ---- & 0.00002 & 0.00000 & 0.00000 & 0.99998 \\
\hline Li1UI & $-\overline{---}$ & 0.00000 & 0.00000 & 0.00000 & 1.00000 \\
\hline Li2UI & ---- & 0.00000 & 0.00000 & 0.00000 & 1.00000 \\
\hline at1Ul & ---- & 0.00000 & 0.00000 & 0.00022 & 0.99978 \\
\hline at2UI & ---- & 0.00000 & 0.00000 & 0.01527 & 0.98473 \\
\hline at3UI & ---- & 0.00000 & 0.00071 & 0.99914 & 0.00015 \\
\hline at4UI & ---- & 0.00000 & 0.00000 & 0.00005 & 0.99995 \\
\hline ga1Ul & --- & 1.00000 & 0.00000 & 0.00000 & 0.00000 \\
\hline ga2Ul & ---- & 1.00000 & 0.00000 & 0.00000 & 0.00000 \\
\hline ga3UI & ---- & 1.00000 & 0.00000 & 0.00000 & 0.00000 \\
\hline ga4UI & ---- & 1.00000 & 0.00000 & 0.00000 & 0.00000 \\
\hline ga5Ul & --- & 1.00000 & 0.00000 & 0.00000 & 0.00000 \\
\hline ga6UI & ---- & 1.00000 & 0.00000 & 0.00000 & 0.00000 \\
\hline ga7UI & --- & 1.00000 & 0.00000 & 0.00000 & 0.00000 \\
\hline SA1UI & ---- & 1.00000 & 0.00000 & 0.00000 & 0.00000 \\
\hline SC1UI & --- & 0.00000 & 0.00000 & 1.00000 & 0.00000 \\
\hline SC2UI & ---- & 0.00000 & 0.00000 & 1.00000 & 0.00000 \\
\hline SC3UI & --- & 0.00000 & 0.00006 & 0.99993 & 0.00001 \\
\hline SC4UI & --- & 0.00000 & 0.00000 & 1.00000 & 0.00000 \\
\hline SC5UI & ---- & 0.00000 & 0.00000 & 1.00000 & 0.00000 \\
\hline SC6UI & ---- & 0.00000 & 0.00000 & 1.00000 & 0.00000 \\
\hline
\end{tabular}



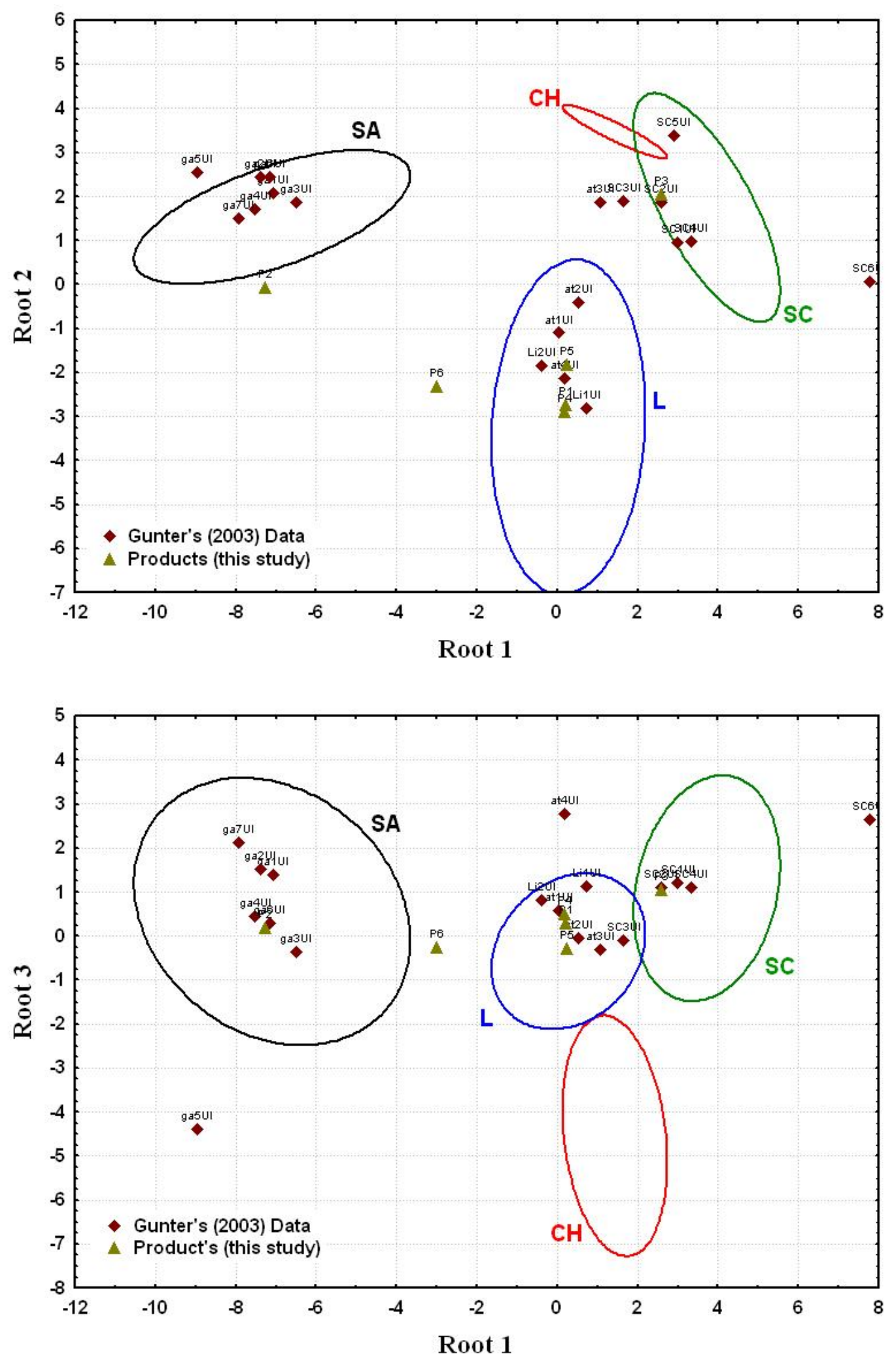


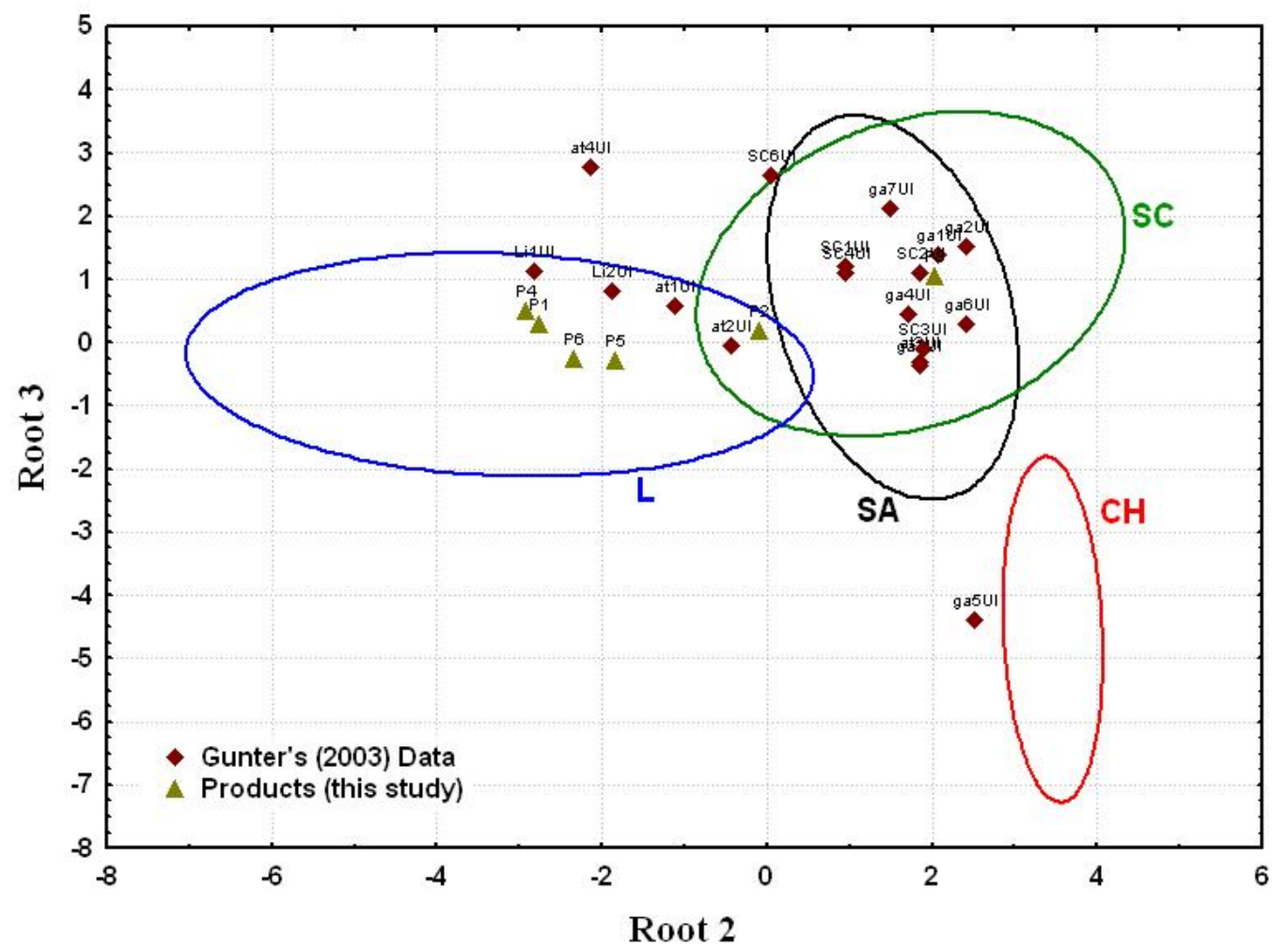




\begin{abstract}
Appendix E
Results of Six-Category Discriminant Analyses
\end{abstract}




\section{Six-Category Model, Original Element Set}

Element Set:

$\mathrm{SiO}_{2}, \mathrm{TiO}_{2}, \mathrm{Al}_{2} \mathrm{O} 3, \mathrm{FeO}, \mathrm{MnO}, \mathrm{CaO}, \mathrm{Na}_{2} \mathrm{O}, \mathrm{K}_{2} \mathrm{O}, \mathrm{Ba}, \mathrm{Ce}, \mathrm{Co}, \mathrm{Cr}, \mathrm{Cs}, \mathrm{Cu}, \mathrm{Ga}, \mathrm{La}, \mathrm{Ni}, \mathrm{Sc}, \mathrm{Sm} \mathrm{V}$, $\mathrm{Zn}$

\section{Categories:}

\begin{tabular}{|l|c|l|c|}
\hline \multicolumn{1}{|c|}{ Category } & Abbreviation & \multicolumn{1}{|c|}{ Sample IDs } & $\begin{array}{c}\text { No. } \\
\text { Samples }\end{array}$ \\
\hline South Africa & SA & GS-1, GS-3, GS-13, GS-17, GS-18,PVC1, PVC2, PVC3 & 8 \\
\hline China & CH & GS-7, GS-12, GS-16 & 3 \\
\hline $\begin{array}{l}\text { South Carolina } \\
\text { Group 1 }\end{array}$ & SC-1 & SC4, SC5, SC6, SC9, SC10, SC11 & 6 \\
\hline $\begin{array}{l}\text { South Carolina } \\
\text { Group 2 }\end{array}$ & SC-2 & GS-11, SG-15, SC2, SC3, SC7, SC8, PVC5 & 7 \\
\hline $\begin{array}{l}\text { Libby } \\
\text { Group 1 }\end{array}$ & L-1 & 1A, 4A, 9A, 10A & 4 \\
\hline $\begin{array}{l}\text { Libby } \\
\text { Group 2 }\end{array}$ & L-2 & GS-2, GS-4, GS-10, 2A, 3A, 5A, 6A, 7A, 8A, 11A & 10 \\
\hline \multicolumn{1}{|c|}{ Total Number of Samples = } \\
\hline
\end{tabular}

\section{Discriminant Function Analysis.}

\begin{tabular}{|c|c|c|c|c|c|c|c|}
\hline \multirow{2}{*}{$N=38$} & \multicolumn{7}{|c|}{$\begin{array}{l}\text { Discriminant Function Analysis Summary (fprinttraceln1) } \\
\text { Step 9, N of vars in model: } 9 \text {; Grouping: Category (6 grps) } \\
\text { Wilks' Lambda: } .00002 \text { approx. F }(45,110)=24.143 p<0.0000\end{array}$} \\
\hline & $\begin{array}{l}\text { Element } \\
\text { Added }\end{array}$ & Wilks' $\Lambda$ & $\begin{array}{c}\text { Wilks' } \\
\text { Partial } \Lambda \\
\end{array}$ & F-Remove & p-Level & Tolerance & $\begin{array}{c}\text { Correlated Variables } \\
\text { Removed }\end{array}$ \\
\hline 1 & V & 0.000071 & 0.3299 & 9.75 & 3.4945E-05 & 0.5914 & $\mathrm{TiO}_{2}, \mathrm{MnO}, \mathrm{Na}_{2} \mathrm{O}, \mathrm{Cs}$ \\
\hline 2 & $\mathrm{Sm}$ & 0.000130 & 0.1804 & 21.81 & 3.2768E-08 & 0.2678 & $\mathrm{La}, \mathrm{Ce}$ \\
\hline 3 & Sc & 0.000079 & 0.2975 & 11.33 & 1.0769E-05 & 0.2285 & none \\
\hline 4 & $\mathrm{Ni}$ & 0.000083 & 0.2846 & 12.07 & $6.4804 \mathrm{E}-06$ & 0.5591 & none \\
\hline 5 & $\mathrm{Ga}$ & 0.000049 & 0.4821 & 5.16 & 2.3657E-03 & 0.3182 & $\mathrm{Al}_{2} \mathrm{O}_{3}$ \\
\hline 6 & $\mathrm{~K}_{2} \mathrm{O}$ & 0.000140 & 0.1672 & 23.90 & 1.3487E-08 & 0.0971 & none \\
\hline 7 & $\mathrm{Ba}$ & 0.000088 & 0.2673 & 13.16 & $3.1512 \mathrm{E}-06$ & 0.1182 & none \\
\hline 8 & $\mathrm{Zn}$ & 0.000038 & 0.6215 & 2.92 & 3.3653E-02 & 0.5474 & $\mathrm{Cu}$ \\
\hline 9 & $\mathrm{CaO}$ & 0.000037 & 0.6376 & 2.73 & 4.3387E-02 & 0.6756 & none \\
\hline
\end{tabular}




\begin{tabular}{|c|c|c|c|c|c|c|}
\hline \multirow{2}{*}{$\begin{array}{l}\mathrm{n}=38 \\
\text { Element }\end{array}$} & \multicolumn{6}{|c|}{$\begin{array}{l}\text { Variables currently not in the model (fprinttraceln1) } \\
\text { Df for all F-tests: } 5,23\end{array}$} \\
\hline & Wilks' $\Lambda$ & $\begin{array}{c}\text { Wilks' } \\
\text { Partial } \Lambda \\
\end{array}$ & $\begin{array}{l}F \text { to } \\
\text { Enter }\end{array}$ & p-level & Toler. & 1-Toler. \\
\hline $\mathrm{SiO}_{2}$ & 0.000015 & 0.647741 & 2.501605 & 0.059903 & 0.737388 & 0.262612 \\
\hline $\mathrm{TiO}_{2}$ & 0.000018 & 0.750680 & 1.527776 & 0.220233 & 0.325465 & 0.674536 \\
\hline $\mathrm{Al}_{2} \mathrm{O}_{3}$ & 0.000020 & 0.830799 & 0.936839 & 0.475802 & 0.178166 & 0.821834 \\
\hline $\mathrm{FeO}$ & 0.000015 & 0.658278 & 2.387927 & 0.06 & 05 & 995 \\
\hline MnO & 0.000015 & 0.645487 & 2.526403 & 0.05 & 0.78 & 0.211099 \\
\hline $\mathrm{Na}_{2} \mathrm{O}$ & 0.000016 & 0.687560 & 2.090322 & 0.103344 & 0.413220 & 0.586780 \\
\hline $\mathrm{Ce}$ & 0.000015 & 0.647546 & 2.503743 & 0.059735 & 0.198209 & 0.801791 \\
\hline Co & 0.000016 & 0.701345 & 1.958823 & 0.123280 & 0.33 & 0.666557 \\
\hline $\mathrm{Cr}$ & 0.000021 & 0.895060 & 0.539323 & 0.744482 & 0.443738 & 0.556262 \\
\hline Cs & 0.000020 & 0.860765 & 0.744087 & 0.598548 & 0.179826 & 0.820174 \\
\hline $\mathrm{Cu}$ & 0.000015 & 0.643308 & 2.550539 & 0.056185 & 0.33 & 0.668445 \\
\hline La & 0.000023 & 0.986088 & 0.064898 & 0.996762 & 0.548343 & 0.451657 \\
\hline
\end{tabular}

\begin{tabular}{|c|r|r|r|r|r|r|}
\cline { 2 - 8 } \multicolumn{1}{c|}{} & \multicolumn{6}{c|}{ Squared Mahalanobis Distances (fprinttraceln1) } \\
\hline Category & \multicolumn{1}{c|}{ CH } & \multicolumn{1}{c|}{ L1 } & \multicolumn{1}{c|}{ L2 } & \multicolumn{1}{c|}{ SA } & \multicolumn{1}{c|}{ SC1 } & \multicolumn{1}{c|}{ SC2 } \\
\hline CH & 0.000 & 100.830 & 75.667 & 197.590 & 182.152 & 51.436 \\
L1 & 100.830 & 0.000 & 34.884 & 225.900 & 184.275 & 95.104 \\
L2 & 75.667 & 34.884 & 0.000 & 265.031 & 128.534 & 43.349 \\
SA & 197.590 & 225.900 & 265.031 & 0.000 & 465.624 & 273.045 \\
SC1 & 182.152 & 184.275 & 128.534 & 465.624 & 0.000 & 62.073 \\
SC2 & 51.436 & 95.104 & 43.349 & 273.045 & 62.073 & 0.000 \\
\hline
\end{tabular}

\begin{tabular}{|c|r|r|r|r|r|r|}
\cline { 2 - 8 } \multicolumn{1}{c|}{} & \multicolumn{7}{c|}{ F-values; df $=9,25$ (fprinttraceln1) } \\
\hline Category & CH & \multicolumn{1}{c|}{ L1 } & \multicolumn{1}{c|}{ L2 } & \multicolumn{1}{c|}{ SA } & \multicolumn{1}{c|}{ SC1 } & \multicolumn{1}{c|}{ SC2 } \\
\hline CH & & 14.404 & 14.551 & 35.926 & 30.359 & 9.001 \\
L1 & 14.404 & & 8.306 & 50.200 & 36.855 & 20.174 \\
L2 & 14.551 & 8.306 & & 98.160 & 40.167 & 14.875 \\
SA & 35.926 & 50.200 & 98.160 & & 133.035 & 84.947 \\
SC1 & 30.359 & 36.855 & 40.167 & 133.035 & & 16.712 \\
SC2 & 9.001 & 20.174 & 14.875 & 84.947 & 16.712 & \\
\hline
\end{tabular}

\begin{tabular}{|c|c|c|c|c|c|c|}
\hline & \multicolumn{6}{|c|}{ p-levels (fprinttraceln1) } \\
\hline Category & $\mathrm{CH}$ & L1 & L2 & SA & SC1 & SC2 \\
\hline $\mathrm{CH}$ & \multicolumn{6}{|c|}{ 7.6467E-08 6.9097E-08 4.1375E-12 2.7638E-11 6.3904E-06 } \\
\hline L1 & 7.6467E-08 & & 1.2859E-05 & $8.7353 \mathrm{E}-14$ & 3.0934E-12 & $2.3847 \mathrm{E}-09$ \\
\hline L2 & 6.9097E-08 & 1.2859E-05 & & 3.0074E-17 & 1.1558E-12 & $5.5456 \mathrm{E}-08$ \\
\hline SA & $4.1375 \mathrm{E}-12$ & 8.7353E-14 & 3.0074E-17 & & 7.5376E-19 & $1.7131 \mathrm{E}-16$ \\
\hline SC1 & $2.7638 \mathrm{E}-11$ & 3.0934E-12 & 1.1558E-12 & 7.5376E-19 & & 1.7007E-08 \\
\hline $\mathrm{SC} 2$ & 6.3904E-06 & 2.3847E-09 & $5.5456 \mathrm{E}-08$ & $1.7131 \mathrm{E}-16$ & 1.7007E-08 & \\
\hline
\end{tabular}




\begin{tabular}{|c|c|c|c|c|c|c|c|c|c|c|c|}
\hline & \multicolumn{11}{|c|}{ Summary of Stepwise Analysis (fprinttraceln1) } \\
\hline $\begin{array}{c}\text { Variable } \\
\text { Enterl } \\
\text { Remove }\end{array}$ & Step & $\begin{array}{c}\text { F to } \\
\text { enterl } \\
\text { remove }\end{array}$ & df 1 & df 2 & p-level & $\begin{array}{c}\text { No. of } \\
\text { vars. } \\
\text { In Model }\end{array}$ & Lambda & F-value & df 1 & df 2 & p-level \\
\hline $\mathbf{V}$-(E) & 1 & 59.974 & 5 & 32 & $2.609 \mathrm{E}-15$ & 1 & 0.096424 & 59.974 & 5 & 32 & $2.609 \mathrm{E}-15$ \\
\hline Sm-(E) & 2 & 26.239 & 5 & 31 & 2.779E-10 & 2 & 0.018429 & 39.471 & 10 & 62 & $3.886 \mathrm{E}-23$ \\
\hline Sc-(E) & 3 & 19.221 & 5 & 30 & 1.493E-08 & 3 & 0.004384 & 34.111 & 15 & 83 & $3.828 \mathrm{E}-29$ \\
\hline $\mathrm{Ni}-(\mathrm{E})$ & 4 & 15.907 & 5 & 29 & 1.492E-07 & 4 & 0.001171 & 32.309 & 20 & 97 & $0.000 \mathrm{E}+00$ \\
\hline Ga-(E) & 5 & 8.383 & 5 & 28 & 6.060E-05 & 5 & 0.000469 & 29.002 & 25 & 106 & $0.000 E+00$ \\
\hline $\mathbf{K}_{\mathbf{2}} \mathbf{O}-(\mathrm{E})$ & 6 & 5.910 & 5 & 27 & 8.174E-04 & 6 & 0.000224 & 26.305 & 30 & 110 & $0.000 \mathrm{E}+00$ \\
\hline Ba-(E) & 7 & 14.198 & 5 & 26 & $9.724 \mathrm{E}-07$ & 7 & 0.000060 & 29.011 & 35 & 112 & $0.000 \mathrm{E}+00$ \\
\hline Zn-(E) & 8 & 3.149 & 5 & 25 & 2.434E-02 & 8 & 0.000037 & 26.273 & 40 & 112 & $0.000 \mathrm{E}+00$ \\
\hline CaO-(E) & 9 & 2.728 & 5 & 24 & 4.339E-02 & 9 & 0.000023 & 24.143 & 45 & 110 & $0.000 \mathrm{E}+00$ \\
\hline
\end{tabular}

\begin{tabular}{|c|r|r|r|r|r|r|}
\hline \multicolumn{6}{|c|}{ Chi-Square Tests with Successive Roots Removed (fprinttraceln1) } \\
\hline $\begin{array}{c}\text { Roots } \\
\text { Removed }\end{array}$ & $\begin{array}{c}\text { Eigen- } \\
\text { value }\end{array}$ & $\begin{array}{c}\text { Canonical } \\
\text { R }\end{array}$ & $\begin{array}{c}\text { Wilks' } \\
\text { Lambda }\end{array}$ & Chi-Sqr. & df & p-level \\
\hline 0 & 58.62 & 0.9916 & 0.000023 & 314.44 & 45 & $0.000 \mathrm{E}+00$ \\
1 & 14.56 & 0.9673 & 0.001400 & 193.84 & 32 & $0.000 \mathrm{E}+00$ \\
2 & 6.10 & 0.9269 & 0.021797 & 112.87 & 21 & $1.432 \mathrm{E}-14$ \\
3 & 2.52 & 0.8459 & 0.154733 & 55.05 & 12 & $1.774 \mathrm{E}-07$ \\
4 & 0.84 & 0.6753 & 0.543986 & 17.96 & 5 & $2.996 \mathrm{E}-03$ \\
\hline
\end{tabular}

\begin{tabular}{|c|c|c|c|c|c|c|c|c|c|c|c|}
\hline \multirow[b]{2}{*}{ Variable } & \multicolumn{5}{|c|}{$\begin{array}{l}\text { Raw Coefficients (fprinttraceln1) } \\
\text { for Canonical Variables }\end{array}$} & \multicolumn{6}{|c|}{$\begin{array}{l}\text { Standardized Coefficients (fprinttraceln1) } \\
\text { for Canonical Variables }\end{array}$} \\
\hline & Root 1 & Root 2 & Root 3 & Root 4 & Root 5 & Variable & Root 1 & Root 2 & Root 3 & Root 4 & Root 5 \\
\hline $\mathbf{V}$ & 3.3563 & 0.39857 & -1.44983 & -1.5702 & -0.47662 & $\mathbf{V}$ & 0.92563 & 0.10992 & -0.399840 & -0.433042 & 1446 \\
\hline Sm & -0.4869 & -1.87879 & & 510 & & SM & 814 & -1.72909 & 0.263382 & 966 & 335 \\
\hline Sc & & 2.80671 & & & & SC & & & & & \\
\hline $\mathrm{Ni}$ & & 344 & & & & 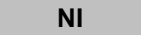 & & & & & \\
\hline Ga & & -0.59144 & & 31 & & G & 201 & 305 & & & \\
\hline $\mathrm{K}_{2} \mathrm{O}$ & -3.8 & 1.30642 & -1 . & -0.9936 & -1 & K2O & 650 & 0.87832 & -0. & 008 & -0. \\
\hline $\mathrm{Ba}$ & & -1.5 & & & & & 60 & & & & \\
\hline $\mathrm{Zr}$ & & -0.56622 & -3 & 700 & $42 \mid$ & $<$ & 576 & -0.12534 & -0 . & & \\
\hline $\mathrm{CaO}$ & 15 & 0.65764 & & 376 & 80 & CAO & 0.05726 & 0.46218 & 0.263539 & -0.588639 & 0.237399 \\
\hline & 64.4706 & -3.63909 & 12.18640 & -12.1094 & $|-3.46947| \mid$ & & $-\cdots$ & --- & 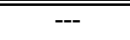 & -- & --- \\
\hline & & 14.56459 & & & & & 58.62018 & & & & \\
\hline Cum.Prob. & 0.7094 & 0.88561 & 0.95941 & 0.9899 & 1.00000 & Cum.Prob. & 0.70937 & 0.88561 & 0.959414 & 0.989856 & 1.000000 \\
\hline
\end{tabular}

\begin{tabular}{|c|c|c|c|c|c|}
\hline \multirow[b]{2}{*}{ Variable } & \multicolumn{5}{|c|}{$\begin{array}{l}\text { Factor Structure Matrix (fprinttraceln1) } \\
\text { Correlations Variables - Canonical Roots } \\
\text { (Pooled-within-groups correlations) }\end{array}$} \\
\hline & Root 1 & Root 2 & Root 3 & Root 4 & Root 5 \\
\hline $\mathbf{V}$ & 0.377078 & -0.17906 & -0.248818 & -0.140956 & -0.410535 \\
\hline Sm & -0.004912 & -0.526233 & -0.042542 & -0.343798 & 0.285191 \\
\hline Sc & 0.147497 & 0.048552 & 0.3 & 487 & 0.023416 \\
\hline $\mathrm{Ni}$ & -0.037456 & 0.089301 & -0.583399 & 0.146702 & 0.526307 \\
\hline $\mathbf{G a}$ & 0.059373 & -0.118678 & 0.012484 & 0.605639 & -0.340613 \\
\hline $\mathrm{K}_{2} \mathrm{O}$ & -0.025735 & 0.064046 & 0.057144 & 0.172418 & -0.730053 \\
\hline $\mathrm{Ba}$ & 0.153340 & 0.071486 & 0.167291 & 0.202112 & -0.662494 \\
\hline $\mathrm{Zn}$ & 0.074140 & -0.386620 & -0.440691 & 0.223530 & -0.290623 \\
\hline $\mathrm{CaO}$ & 0.001828 & -0.114730 & 0.147170 & -0.707670 & 0.284313 \\
\hline
\end{tabular}

Means of Canonical Variables (fprinttraceln1) 


\begin{tabular}{|c|r|r|r|r|r|}
\hline Category & \multicolumn{1}{|c|}{ Root 1 } & \multicolumn{1}{l}{ Root 2 } & \multicolumn{1}{l|}{ Root 3 } & \multicolumn{1}{c|}{ Root 4 } & \multicolumn{1}{c|}{ Root 5 } \\
\hline CH & -0.6811 & -0.04856 & -5.65414 & -2.59790 & -1.25928 \\
L1 & 0.0886 & 5.02963 & 2.70262 & -2.89144 & 0.86851 \\
L2 & 2.4770 & 3.94294 & 0.05650 & 1.47627 & -0.51707 \\
SA & -12.5793 & -2.07951 & 0.81641 & 0.33901 & -0.07442 \\
SC1 & 8.7193 & -5.03958 & 2.33519 & -0.44094 & -0.63373 \\
SC2 & 3.6053 & -1.78982 & -2.13650 & 0.64719 & 1.41031 \\
\hline
\end{tabular}




\begin{tabular}{|c|c|c|c|c|c|c|}
\hline & \multicolumn{6}{|c|}{ Unstandardized Canonical Scores (fprinttraceln1) } \\
\hline Samples & Group & Root 1 & Root 2 & Root 3 & Root 4 & Root 5 \\
\hline CH GS-7 & $\mathrm{CH}$ & -0.5428 & -1.58531 & -3.66130 & -2.58704 & -0.28982 \\
\hline CH GS-12 & $\mathrm{CH}$ & -1.1147 & 0.81311 & -7.65247 & -3.53614 & -2.74085 \\
\hline CH GS-16 & $\mathrm{CH}$ & -0.3857 & 0.62652 & -5.64867 & -1.67050 & -0.74716 \\
\hline L 1A & L1 & -0.0359 & 6.31523 & 3.19117 & -4.09879 & 1.50281 \\
\hline L 4A & L1 & 36 & 4.7 & 2.8 & 080 & 1.06546 \\
\hline L 9A & L1 & -0.0105 & 4.31265 & & -2.05889 & 0.86624 \\
\hline L10A & L1 & 0.1773 & 4.78834 & 2.55470 & -4.53726 & 0.03955 \\
\hline L GS-2 & L2 & 2.0263 & 3.69937 & -0.06796 & 093 & -0.20982 \\
\hline L G & L2 & 3.2429 & 3.62852 & -0.3 & 982 & -0.08517 \\
\hline L GS-10 & L2 & 2.5178 & 4.48920 & 0.0 & 3128 & 0.09266 \\
\hline LA & L2 & 2.9359 & 4.69064 & 0.11391 & 1.49627 & -0.75134 \\
\hline L $3 A$ & L2 & 3.2063 & 3.77980 & 0.62458 & 2.59010 & 0.13607 \\
\hline L 5A & L2 & 2.2878 & 5.44215 & -0.22702 & 1851 & -0.95389 \\
\hline L 6A & L2 & 2.1371 & 2.40532 & 222 & 5595 & -1.62602 \\
\hline L 7A & L2 & 0.8605 & 4.36895 & 449 & 6487 & -0.34483 \\
\hline L 8A & L2 & 2.8 & 2.83769 & & 769 & 0431 \\
\hline L 11A & L2 & & 4.0 & & 723 & 404 \\
\hline & S & 50 & -3.5 & -0 . & 461 & 897 \\
\hline & $S$ & & -3.7 & & 788 & 004 \\
\hline & SA & & -2.0 & & 972 & 342 \\
\hline & SA & & -1.1 & & 260 & 7435 \\
\hline SA & SA & & -0.1 & 2.4 & 677 & 238 \\
\hline C2 & SA & -1 & -2.4 & & 174 & 0.04452 \\
\hline C3 & SA & & -2.9 & & 249 & -0.27239 \\
\hline SA & SA & -11 & -0.3 & & 124 & -0.60001 \\
\hline SC4 & SC1 & & -4.9 & & 943 & -0.18377 \\
\hline SC5 & & & -4.79381 & -0.5 & 879 & 0.15197 \\
\hline Sc6 & & & -4.57157 & & -0.07367 & 6036 \\
\hline & & & -6.2 & & 198 & -1.40102 \\
\hline & & & -4.0 & & 748 & 853 \\
\hline S & & & -5.5 & & 822 & 139 \\
\hline & & & -1.1 & -2.3 & 17 & 307 \\
\hline & SC2 & & -1.1 & -2.3 & 08 & 945 \\
\hline & $\mathrm{S}$ & 77 & -1.8 & -2.6 & 769 & 2099 \\
\hline Sc3 & $\mathrm{SC} 2$ & & -2.2 & -1. & 085 & 1.52425 \\
\hline SC7 & $\mathrm{SC} 2$ & & -3.05888 & -3. & 1.81773 & 1.16149 \\
\hline SC8 & SC2 & 4.3867 & -1.65925 & -1.00559 & -0.63702 & 1.10427 \\
\hline SC PVC5 & SC2 & 6.3899 & -1.47645 & -1.95272 & 0.49881 & 0.23868 \\
\hline P1 & ---- & 2.4991 & 4.28483 & 0.15162 & 1.53633 & 0.16601 \\
\hline P2 & ---- & -11.9636 & -3.96666 & 3.1 & -0.78431 & 0.72931 \\
\hline P3 & ---- & 3.9735 & -2.07418 & -2.77997 & 2.58448 & 0.94604 \\
\hline P4 & ---- & & 3.87929 & & 0.45880 & 0.15829 \\
\hline P5 & ---- & 2.37 & $5.0 \varepsilon$ & -0.7 & 491 & -0.45293 \\
\hline P6 & --- & -1.4281 & 0.28811 & 1.92544 & 0.70924 & 1.64305 \\
\hline
\end{tabular}



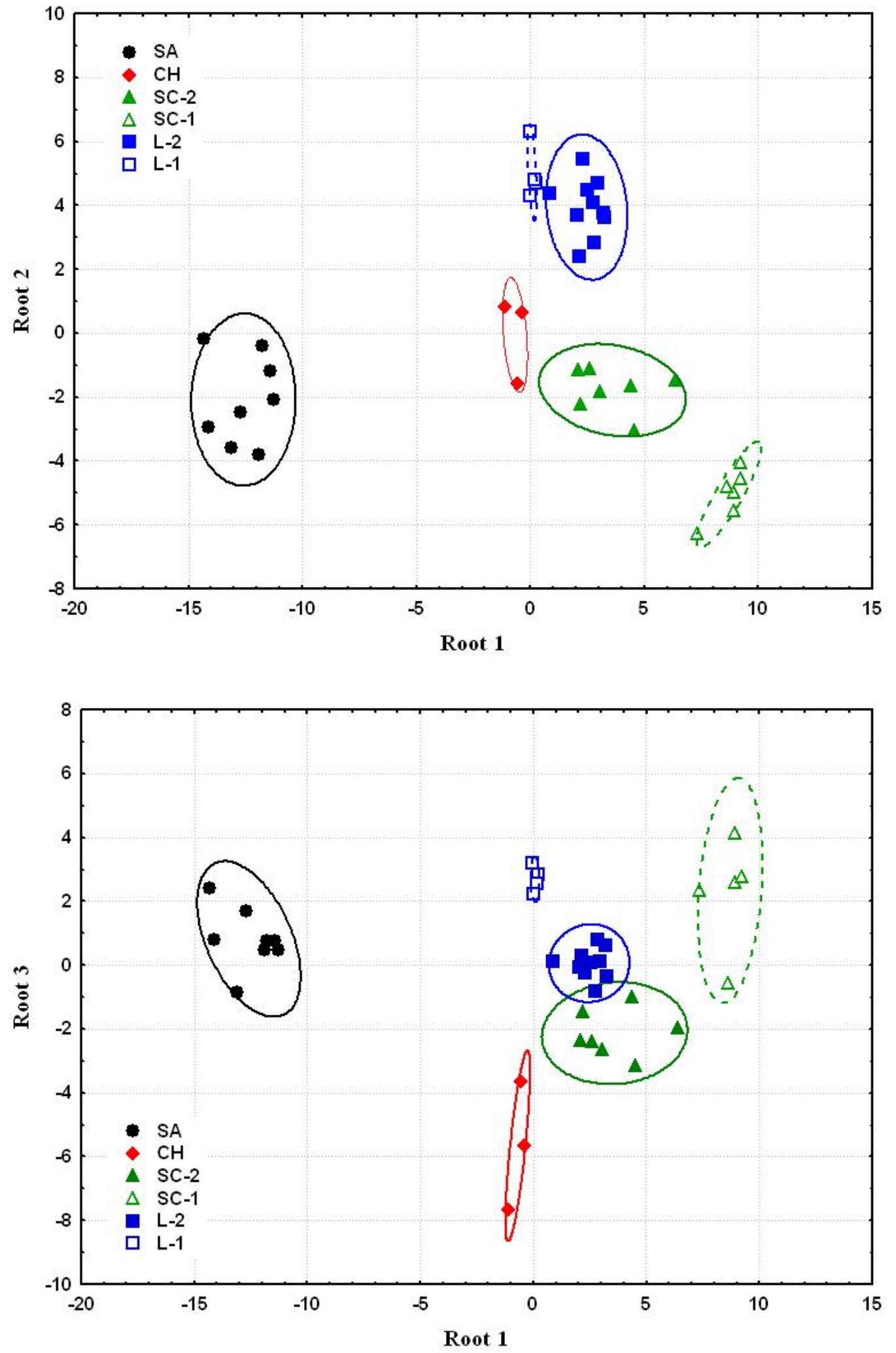

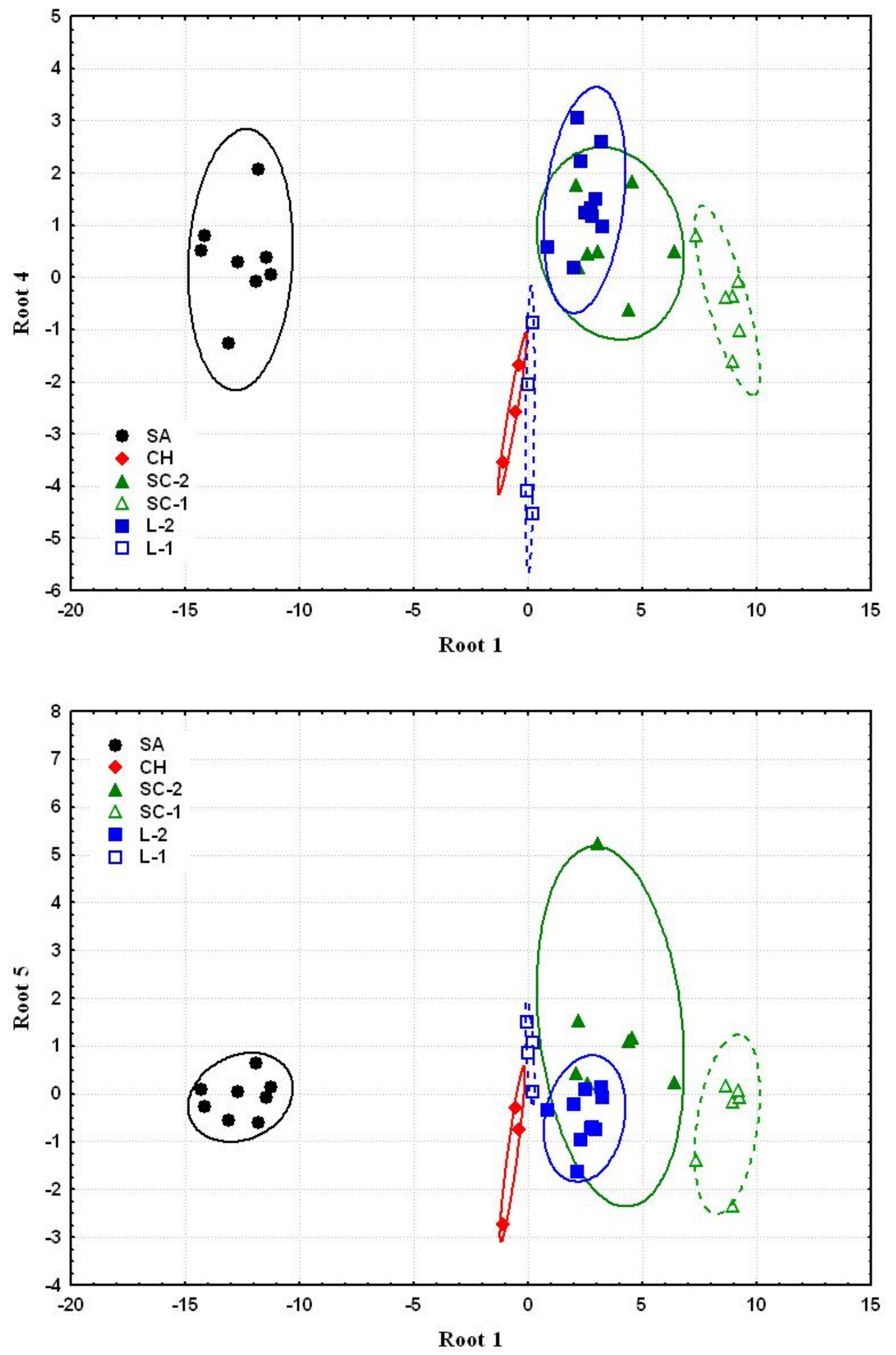

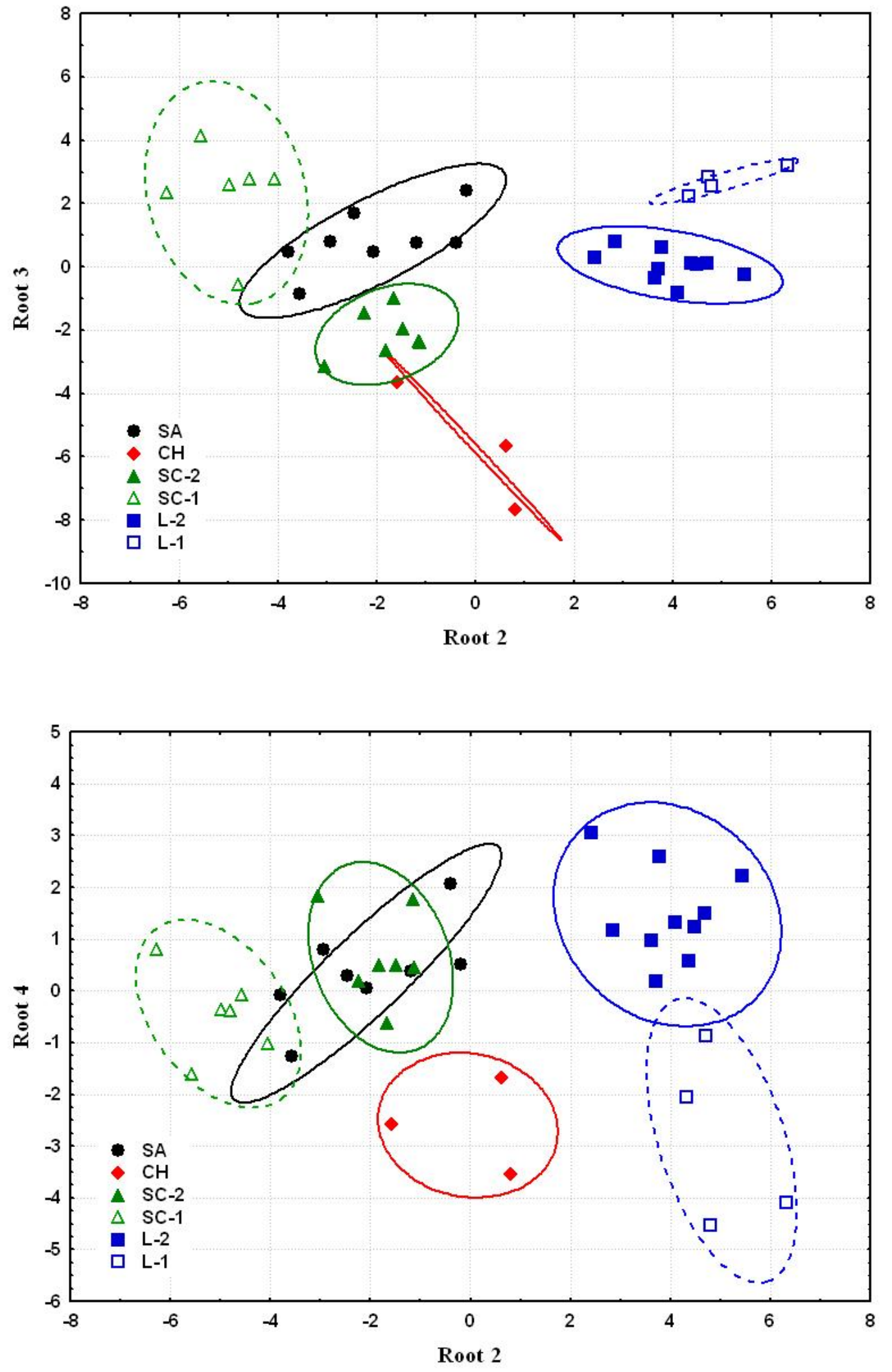

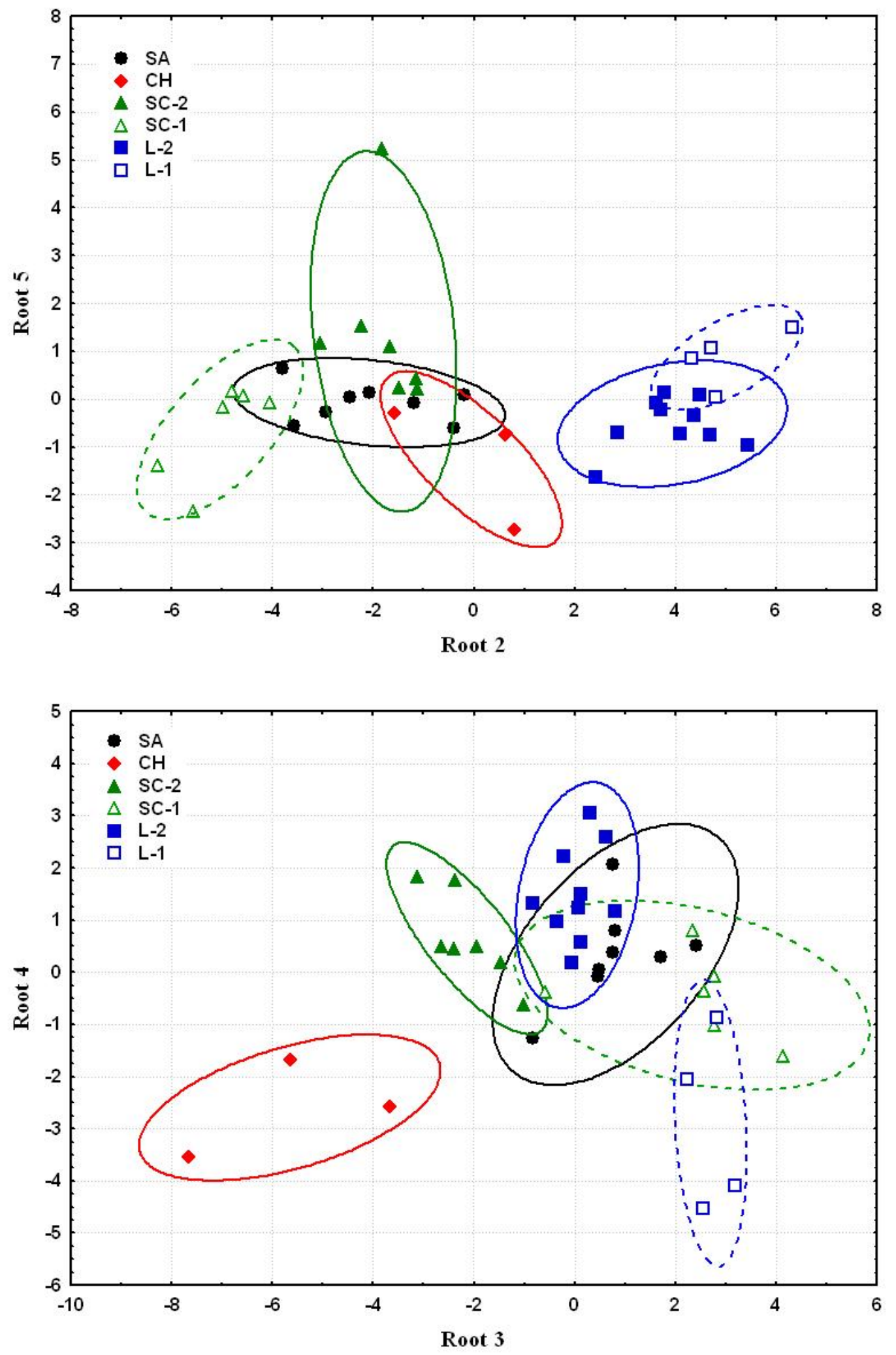

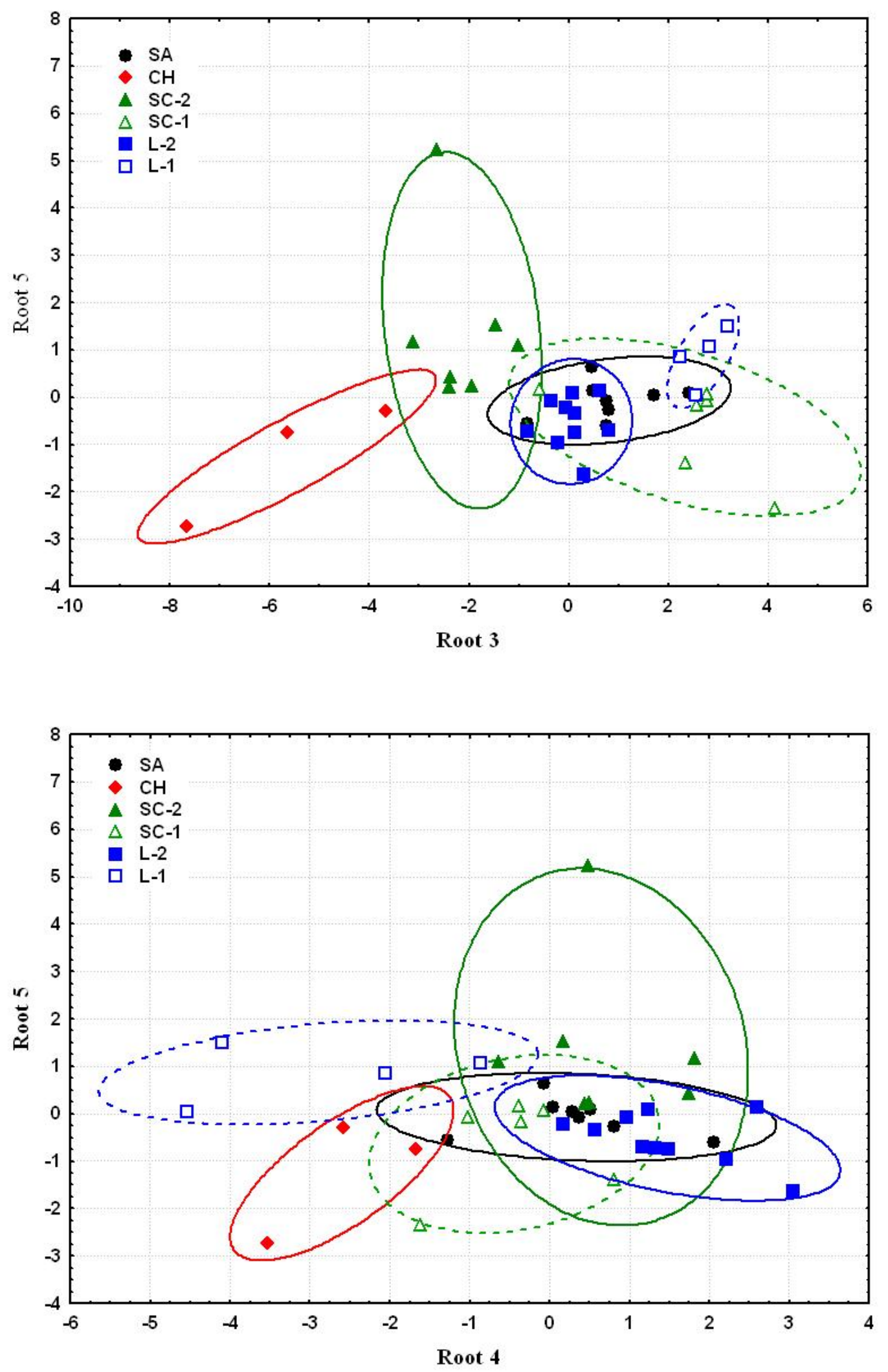


\section{Classification}

\begin{tabular}{|c|c|c|c|c|c|c|}
\hline & \multicolumn{6}{|c|}{ Classification Functions; grouping: Category (fprinttraceln1) } \\
\hline & $\begin{array}{c}\mathrm{CH} \\
\mathrm{p}=.07895\end{array}$ & $\begin{array}{c}L 1 \\
p=.10526\end{array}$ & $\begin{array}{c}L 2 \\
p=.26316\end{array}$ & $\begin{array}{c}\text { SA } \\
p=.21053\end{array}$ & $\begin{array}{c}\text { SC1 } \\
p=.15789\end{array}$ & $\begin{array}{c}\text { SC2 } \\
p=.18421\end{array}$ \\
\hline $\mathbf{V}$ & 183.47 & 175.41 & 180.63 & 128.17 & 197.76 & 185.69 \\
\hline Sm & -51.57 & -58.86 & -59.11 & -40.14 & -44.53 & -49.28 \\
\hline Sc & 302.87 & 323.98 & 331.81 & 256.31 & 329.99 & 319.79 \\
\hline $\mathrm{Ni}$ & 132.60 & 128.13 & 133.71 & 106.25 & 123.01 & 132.11 \\
\hline Ga & 64.02 & 103.78 & 110.78 & 97.86 & 123.44 & 108.68 \\
\hline $\mathrm{K}_{2} \mathrm{O}$ & -230.72 & -239.38 & -249.28 & -199.61 & -285.53 & -260.67 \\
\hline $\mathrm{Ba}$ & 241.25 & 243.96 & 254.64 & 205.23 & 294.33 & 265.47 \\
\hline $\mathrm{Zn}$ & 238.29 & 205.64 & 224.41 & 197.56 & 231.91 & 232.72 \\
\hline $\mathrm{CaO}$ & 13.67 & 21.17 & 15.54 & 11.73 & 12.56 & 12.38 \\
\hline Constant & -2486.32 & -2456.60 & -2677.25 & -1732.97 & -3037.80 & -2752.38 \\
\hline
\end{tabular}

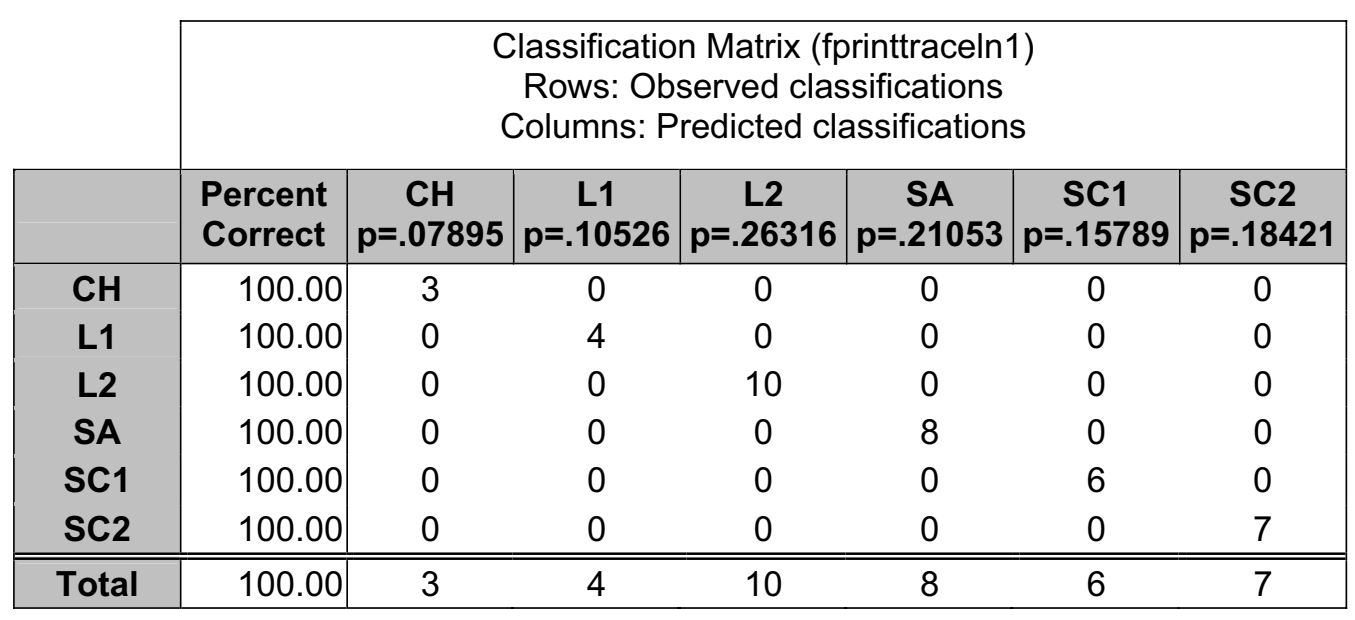




\begin{tabular}{|c|c|c|c|c|c|c|c|}
\hline \multirow[b]{2}{*}{ Samples } & \multicolumn{7}{|c|}{$\begin{array}{l}\text { Classification of Cases (fprinttraceln1) } \\
\text { Incorrect classifications are marked with * }\end{array}$} \\
\hline & $\begin{array}{l}\text { Observed } \\
\text { Classif. }\end{array}$ & $\begin{array}{c}1 \\
p=.07895\end{array}$ & $\begin{array}{c}2 \\
p=.10526\end{array}$ & $\begin{array}{c}3 \\
p=.26316\end{array}$ & $\begin{array}{c}4 \\
p=.21053\end{array}$ & $\begin{array}{c}5 \\
p=.15789\end{array}$ & $\begin{array}{c}6 \\
p=.18421\end{array}$ \\
\hline CH GS-7 & $\mathrm{CH}$ & $\mathrm{CH}$ & SC2 & $\mathrm{L} 2$ & L1 & SC1 & SA \\
\hline CH GS-12 & $\mathrm{CH}$ & $\mathrm{CH}$ & SC2 & L2 & L1 & SA & SC1 \\
\hline CH GS-16 & $\mathrm{CH}$ & $\mathrm{CH}$ & SC2 & L2 & L1 & SA & SC1 \\
\hline L 1A & L1 & L1 & L2 & SC2 & $\mathrm{CH}$ & SA & SC1 \\
\hline L 4A & L1 & L1 & L2 & SC2 & $\mathrm{CH}$ & SA & SC1 \\
\hline L 9A & L1 & L1 & L2 & SC2 & $\mathrm{CH}$ & SA & SC1 \\
\hline L10A & L1 & L1 & L2 & $\mathrm{CH}$ & SC2 & SA & SC1 \\
\hline L GS-2 & L2 & L2 & L1 & SC2 & $\mathrm{CH}$ & SC1 & SA \\
\hline L GS-4 & L2 & L2 & SC2 & L1 & $\mathrm{CH}$ & SC1 & SA \\
\hline L GS-10 & L2 & L2 & L1 & SC2 & $\mathrm{CH}$ & SC1 & SA \\
\hline L A & L2 & L2 & L1 & SC2 & $\mathrm{CH}$ & SC1 & SA \\
\hline L $3 A$ & L2 & L2 & SC2 & $\mathrm{L} 1$ & $\mathrm{CH}$ & SC1 & SA \\
\hline L 5A & L2 & L2 & L1 & SC2 & $\mathrm{CH}$ & SA & SC1 \\
\hline L 6A & L2 & L2 & SC2 & L1 & $\mathrm{CH}$ & SC1 & SA \\
\hline L 7A & L2 & L2 & L1 & SC2 & $\mathrm{CH}$ & SA & SC1 \\
\hline L 8A & L2 & L2 & SC2 & L1 & $\mathrm{CH}$ & SC1 & SA \\
\hline L 11A & L2 & L2 & L1 & SC2 & $\mathrm{CH}$ & SC1 & SA \\
\hline SA GS-3 & SA & SA & $\mathrm{CH}$ & L1 & L2 & SC1 & SC2 \\
\hline SA GS-13 & SA & SA & $\mathrm{CH}$ & L1 & L2 & SC1 & SC2 \\
\hline SA GS-17 & SA & SA & $\mathrm{CH}$ & L1 & L2 & SC1 & SC2 \\
\hline SA GS-18 & SA & SA & $\mathrm{CH}$ & L1 & L2 & SC1 & SC2 \\
\hline SA PVC1 & SA & SA & $\mathrm{CH}$ & L1 & L2 & SC1 & SC2 \\
\hline SA PVC2 & SA & SA & $\mathrm{CH}$ & L1 & L2 & SC1 & SC2 \\
\hline SA PVC 3 & SA & SA & $\mathrm{CH}$ & L1 & L2 & SC1 & SC2 \\
\hline SA GS-1 & SA & SA & $\mathrm{CH}$ & L1 & L2 & SC1 & SC2 \\
\hline SC4 & SC1 & SC1 & SC2 & L2 & $\mathrm{CH}$ & L1 & SA \\
\hline SC5 & SC1 & SC1 & SC2 & L2 & $\mathrm{CH}$ & L1 & SA \\
\hline SC6 & SC1 & SC1 & SC2 & L2 & $\mathrm{CH}$ & L1 & SA \\
\hline SC9 & SC1 & SC1 & SC2 & L2 & $\mathrm{CH}$ & L1 & SA \\
\hline SC10 & SC1 & SC1 & SC2 & L2 & $\mathrm{CH}$ & L1 & SA \\
\hline SC11 & SC1 & SC1 & SC2 & $\mathrm{CH}$ & L1 & L2 & SA \\
\hline SC GS-11 & SC2 & SC2 & L2 & $\mathrm{CH}$ & SC1 & L1 & SA \\
\hline SC GS-15 & SC2 & SC2 & L2 & $\mathrm{CH}$ & SC1 & L1 & SA \\
\hline SC2 & SC2 & SC2 & L2 & $\mathrm{CH}$ & SC1 & L1 & SA \\
\hline SC3 & SC2 & SC2 & L2 & $\mathrm{CH}$ & SC1 & L1 & SA \\
\hline SC7 & SC2 & SC2 & SC1 & L2 & $\mathrm{CH}$ & L1 & SA \\
\hline SC8 & SC2 & SC2 & L2 & SC1 & $\mathrm{CH}$ & L1 & SA \\
\hline SC PVC5 & SC2 & SC2 & SC1 & L2 & $\mathrm{CH}$ & L1 & SA \\
\hline P1 & --- & L2 & $\mathrm{L} 1$ & SC2 & $\mathrm{CH}$ & SC1 & SA \\
\hline P2 & --- & SA & $\mathrm{CH}$ & L1 & L2 & SC1 & SC2 \\
\hline P3 & --- & SC2 & L2 & $\mathrm{CH}$ & SC1 & L1 & SA \\
\hline P4 & --- & L2 & L1 & SC2 & $\mathrm{CH}$ & SC1 & SA \\
\hline P5 & --- & L2 & L1 & SC2 & $\mathrm{CH}$ & SA & SC1 \\
\hline P6 & --- & L2 & L1 & SC2 & $\mathrm{CH}$ & SA & SC1 \\
\hline
\end{tabular}




\begin{tabular}{|c|c|c|c|c|c|c|c|}
\hline \multirow[b]{2}{*}{ Samples } & \multicolumn{7}{|c|}{$\begin{array}{l}\text { Squared Mahalanobis Distances from Group Centroids (fprinttraceln1) } \\
\text { Incorrect classifications are marked with * }\end{array}$} \\
\hline & $\begin{array}{l}\text { Observed } \\
\text { Classif. }\end{array}$ & \begin{tabular}{c|c|}
$\mathrm{CH}$ \\
$\mathrm{p}=.07895$
\end{tabular} & $\begin{array}{c}\mathrm{L} 1 \\
\mathrm{p}=.10526\end{array}$ & $\begin{array}{c}\mathrm{L} 2 \\
\mathrm{p}=.26316\end{array}$ & $\begin{array}{c}\text { SA } \\
p=.21053\end{array}$ & $\begin{array}{c}\text { SC1 } \\
p=.15789\end{array}$ & $\begin{array}{c}\mathrm{SC2} \\
\mathrm{p}=.18421\end{array}$ \\
\hline CH GS-7 & $\mathrm{CH}$ & 8.7956 & 87.5936 & 71.5689 & 175.2830 & 139.9053 & 34.4280 \\
\hline CH GS-12 & $\mathrm{CH}$ & .9332 & 143.8322 & 116.1284 & 237. & .6707 & 98.1462 \\
\hline & $\mathrm{CH}$ & 4.0040 & 95.7962 & 64.0365 & 204.6343 & 182.6115 & 46.4669 \\
\hline & L1 & 135.6047 & 10.3361 & 63.4 & 262.1 & & 136.4363 \\
\hline L 4A & L1 & & 8.9091 & 26.0163 & 221.3775 & & \\
\hline L 9A & L1 & 464 & 2.8041 & $26 . \varepsilon$ & 208 & & 78.3887 \\
\hline L10A & L1 & 377 & 5.2859 & 50. & 238. & & 107. \\
\hline & L2 & 776 & 26.6687 & & & & 823 \\
\hline & L2 & 80 & 38.5609 & & 286 & & 36.6218 \\
\hline & L2 & 97 & 32.9 & & 274. & & 49.9405 \\
\hline & L2 & 430 & 37.4091 & & 289. & & 53.5119 \\
\hline L $3 A$ & L2 & 844 & 54.1157 & 10.4 & 296. & & 340 \\
\hline L 5A & L2 & 93.4323 & 44.7476 & & 284. & & 67.4674 \\
\hline L 6A & L2 & & 66.6823 & 14. & & & \\
\hline & L2 & & 22.1 & & & & \\
\hline L 8 & & & & & & & \\
\hline L 1 & & & 49. & & 28 & & \\
\hline & & & 4 & & & & \\
\hline & & & & & & & \\
\hline & & & & & & & 779 \\
\hline & & & 187.7 & 222. & & & 237 \\
\hline & & & 251. & 310. & & & 351 \\
\hline & & & 234.8 & 279 & & & 286 \\
\hline & & & 285.4 & & & & $32 \varepsilon$ \\
\hline & & & 203.8720 & 225. & & & 256 \\
\hline & & & 187.0969 & 132. & & & 65.4675 \\
\hline & & & 191.4194 & 122. & & & 43.7764 \\
\hline & & & & & & & \\
\hline & & & & & & & \\
\hline & & & 172 & 125 & & & \\
\hline & & & & 172. & & & 38 \\
\hline & & & & & & & 52 \\
\hline & & & & & & & 65 \\
\hline SC2 & & & 123. & 83. & 292.7762 & 11 & 24.2415 \\
\hline & & 49.0676 & 87.5054 & 49.4560 & 229.4888 & 5975 & 5.7743 \\
\hline SC7 & & 73.2396 & 146.7915 & 71.6333 & 318.4813 & 64.9127 & 10.1553 \\
\hline SC8 & & 595 & 58 & 44. & 294.6260 & & 4.5921 \\
\hline SC PVC & & & 120. & 54. & 372.5707 & & 13.8636 \\
\hline & --- & 63 & 34.0 & & 270.8628 & $\overline{136}$ & 46.7633 \\
\hline & --- & & 236.6 & 292.8 & & & 282.9089 \\
\hline 13 & --- & & 130.5770 & 54.8 & & & \\
\hline P4 & --- & 81.5674 & 21.4377 & & 253.4153 & 127.6789 & 47.8745 \\
\hline 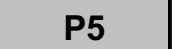 & --- & 79.5402 & 40.9509 & & 281.0815 & 158.3097 & 56.7122 \\
\hline 6 & --- & 90.3263 & 51.7954 & 50.1997 & 147.1153 & 150.8745 & 59.0548 \\
\hline
\end{tabular}




\begin{tabular}{|c|c|c|c|c|c|c|c|}
\hline \multirow[b]{2}{*}{ Samples } & \multicolumn{7}{|c|}{$\begin{array}{l}\text { Posterior Probabilities (fprinttraceln1) } \\
\text { Incorrect classifications are marked with * }\end{array}$} \\
\hline & $\begin{array}{l}\text { Observed } \\
\text { Classif. }\end{array}$ & $\begin{array}{c}\mathrm{CH} \\
\mathrm{p}=.07895\end{array}$ & $\begin{array}{c}L 1 \\
p=.10526 \\
\end{array}$ & $\begin{array}{c}L 2 \\
p=.26316\end{array}$ & $\begin{array}{c}\text { SA } \\
p=.21053\end{array}$ & $\begin{array}{c}\text { SC1 } \\
p=.15789\end{array}$ & $\begin{array}{c}\mathrm{SC} 2 \\
\mathrm{p}=.18421\end{array}$ \\
\hline CH GS-7 & $\mathrm{CH}$ & 0.99999 & 0.00000 & 0.00000 & 0.00000 & 0.00000 & 0.00001 \\
\hline CH GS-12 & $\mathrm{CH}$ & 1.00000 & 0.00000 & 0.00000 & 0.00000 & 0.00000 & 0.00000 \\
\hline CH GS-16 & $\mathrm{CH}$ & 1.00000 & 0.00000 & 0.00000 & 0.00000 & 0.00000 & 0.00000 \\
\hline L $1 A$ & L1 & 0.00000 & 1.00000 & 0.00000 & 0.00000 & 0.00000 & 0.00000 \\
\hline L 4A & L1 & 0.00000 & 0.99952 & 0.00048 & 0.00000 & 0.00000 & 0.00000 \\
\hline L 9A & L1 & 0.00000 & 0.99998 & 0.00002 & 0.00000 & 0.00000 & 0.00000 \\
\hline L10A & L1 & 0.00000 & 1.00000 & 0.00000 & 0.00000 & 0.00000 & 0.00000 \\
\hline L GS-2 & L2 & 0.00000 & 0.00001 & 0.99999 & 0.00000 & 0.00000 & 0.00000 \\
\hline L GS-4 & L2 & 0.00000 & 0.00000 & 1.00000 & 0.00000 & 0.00000 & 0.00000 \\
\hline L GS-10 & L2 & 0.00000 & 0.00000 & 1.00000 & 0.00000 & 0.00000 & 0.00000 \\
\hline L A & L2 & 0.00000 & 0.00000 & 1.00000 & 0.00000 & 0.00000 & 0.00000 \\
\hline L $3 A$ & L2 & 0.00000 & 0.00000 & 1.00000 & 0.00000 & 0.00000 & 0.00000 \\
\hline L 5A & L2 & 0.00000 & 0.00000 & 1.00000 & 0.00000 & 0.00000 & 0.00000 \\
\hline L 6A & L2 & 0.00000 & 0.00000 & 1.00000 & 0.00000 & 0.00000 & 0.00000 \\
\hline L 7A & L2 & 0.00000 & 0.00006 & 0.99994 & 0.00000 & 0.00000 & 0.00000 \\
\hline L 8A & L2 & 0.00000 & 0.00000 & 1.00000 & 0.00000 & 0.00000 & 0.00000 \\
\hline L 11A & L2 & 0.00000 & 0.00000 & 1.00000 & 0.00000 & 0.00000 & 0.00000 \\
\hline SA G & SA & 0.00000 & 0.00000 & 0.0 & & 00 & 000 \\
\hline SA GS-13 & SA & 0.00000 & 0.00000 & 000 & 000 & 00 & 000 \\
\hline SA GS-17 & SA & 0.00000 & 0.00000 & 0.00000 & 000 & 0.00000 & 0.00000 \\
\hline SA GS-18 & SA & 0.00000 & 0.00000 & 0.00000 & 000 & 000 & 0.00000 \\
\hline SA PVC1 & SA & 0.00000 & 0.00000 & 0.00000 & 1.00000 & 0.00000 & 0.00000 \\
\hline SA PVC2 & SA & 0.00000 & 0.00000 & 0.00000 & 1.00000 & 0.00000 & 0.00000 \\
\hline SA PVC3 & SA & 0.00000 & 0.00000 & 0.00000 & 1.00000 & 0.00000 & 0.00000 \\
\hline SA GS-1 & SA & 0.00000 & 0.00000 & 0.00000 & 1.00000 & 0.00000 & 0.00000 \\
\hline SC4 & SC1 & 0.00000 & 0.00000 & 0.00000 & 0.00000 & 1.00000 & 0.00000 \\
\hline SC5 & SC1 & 0.00000 & 0.00000 & 0.00000 & 0.00000 & 1.00000 & 0.00000 \\
\hline SC6 & SC1 & 0.00000 & 0.00000 & 0.00000 & 0.00000 & 1.00000 & 0.00000 \\
\hline SC9 & SC1 & 0.00000 & 0.00000 & 0.00000 & 0.00000 & 1.00000 & 0.00000 \\
\hline SC10 & SC1 & 0.00000 & 0.00000 & & & & 0.00000 \\
\hline SC11 & & & 0.00000 & & & & 0.00000 \\
\hline SC GS-11 & $\mathrm{SC} 2$ & 0.00000 & 0.00000 & 0.00000 & 0.00000 & 0.00000 & 1.00000 \\
\hline SC GS-15 & $\mathrm{SC} 2$ & 0.00000 & 0.00000 & 0.00000 & 0.00000 & 0.00000 & 1.00000 \\
\hline SC2 & $\mathrm{SC} 2$ & 0.00000 & 0.00000 & 0.00000 & 0.00000 & 0.00000 & 1.00000 \\
\hline SC3 & $\mathrm{SC} 2$ & 0.00000 & 0.00000 & 0.00000 & 0.00000 & 0.00000 & 1.00000 \\
\hline SC7 & SC2 & 0.00000 & 0.00000 & 0.00000 & 0.00000 & 0.00000 & 1.00000 \\
\hline SC8 & SC2 & 0.00000 & 0.00000 & 0.00000 & 0.00000 & 0.00000 & 1.00000 \\
\hline SC PVC5 & $\mathrm{SC} 2$ & 0.00000 & 0.00000 & 0.00000 & 0.00000 & 0.00000 & 1.00000 \\
\hline P1 & --- & 0.00000 & 0.00000 & 1.00000 & 0.00000 & 0.00000 & 0.00000 \\
\hline P2 & --- & 0.00000 & 0.00000 & 0.00000 & 1.00000 & 0.00000 & 0.00000 \\
\hline P3 & --- & 0.00000 & 0.00000 & 0.00000 & 0.00000 & 0.00000 & 1.00000 \\
\hline P4 & --- & 0.00000 & 0.00007 & 0.99993 & 0.00000 & 0.00000 & 0.00000 \\
\hline P5 & --- & 0.00000 & 0.00000 & 1.00000 & 0.00000 & 0.00000 & 0.00000 \\
\hline P6 & --- & 0.00000 & 0.15155 & 0.84141 & 0.00000 & 0.00000 & 0.00703 \\
\hline
\end{tabular}



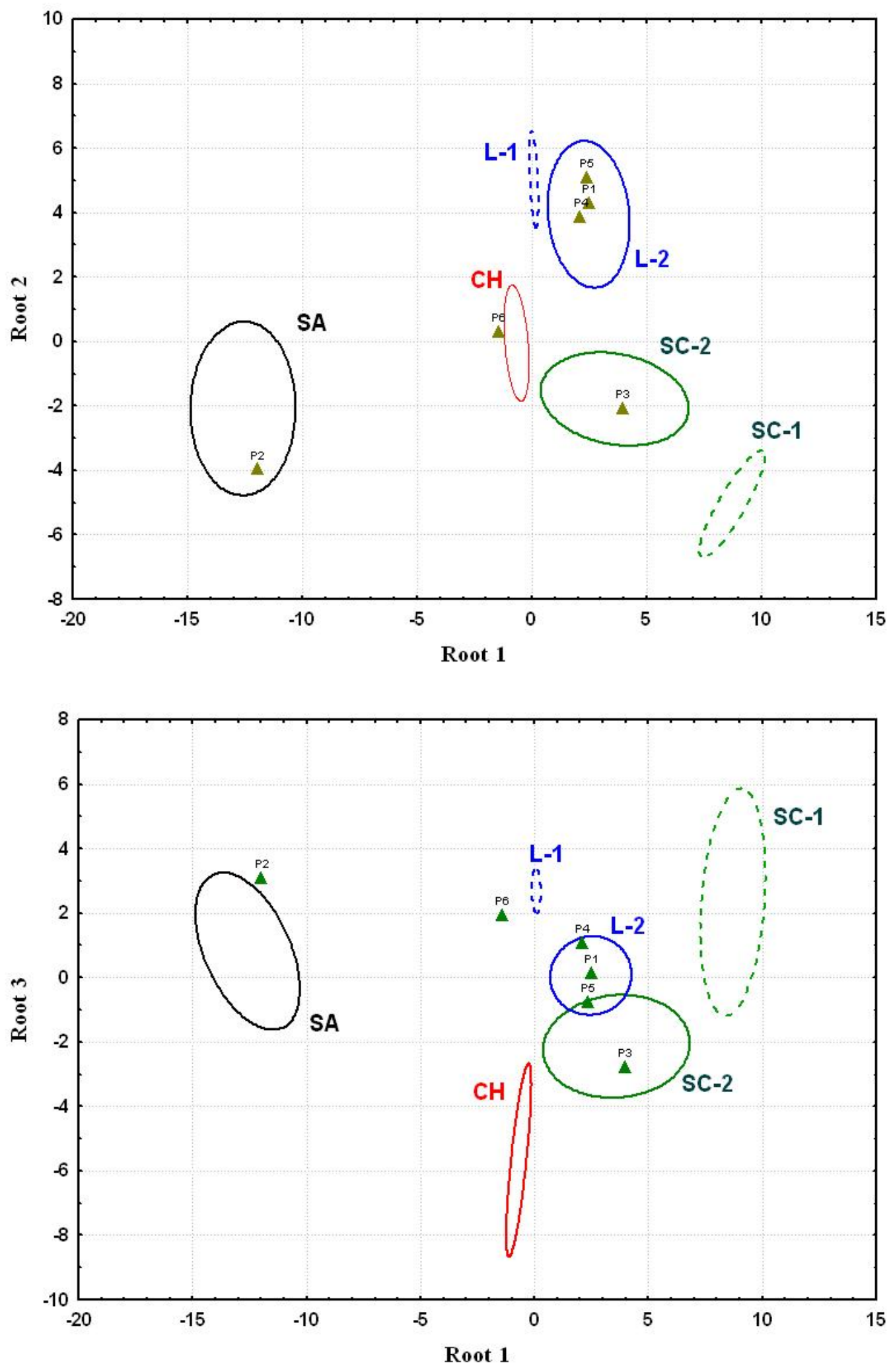

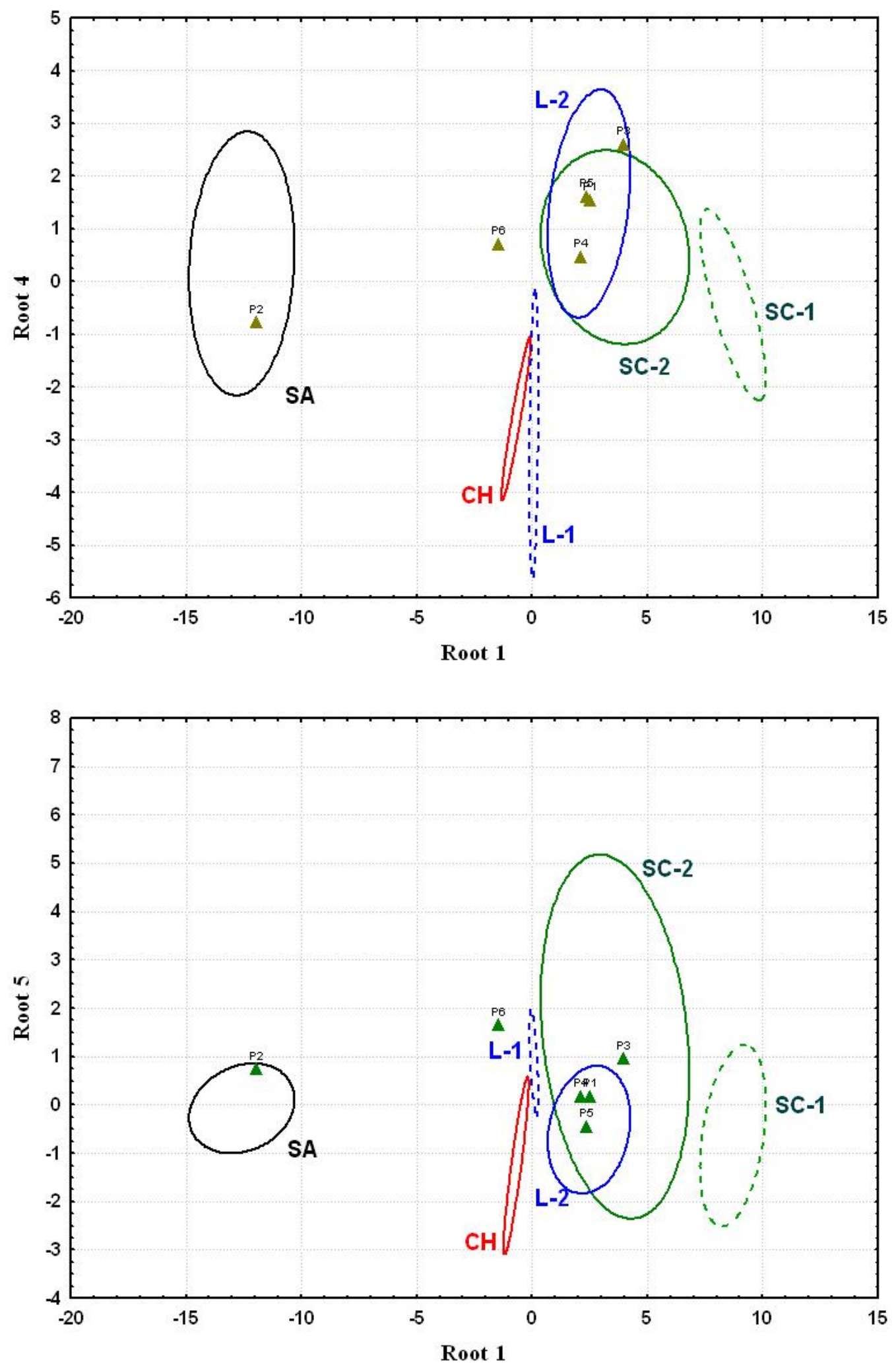

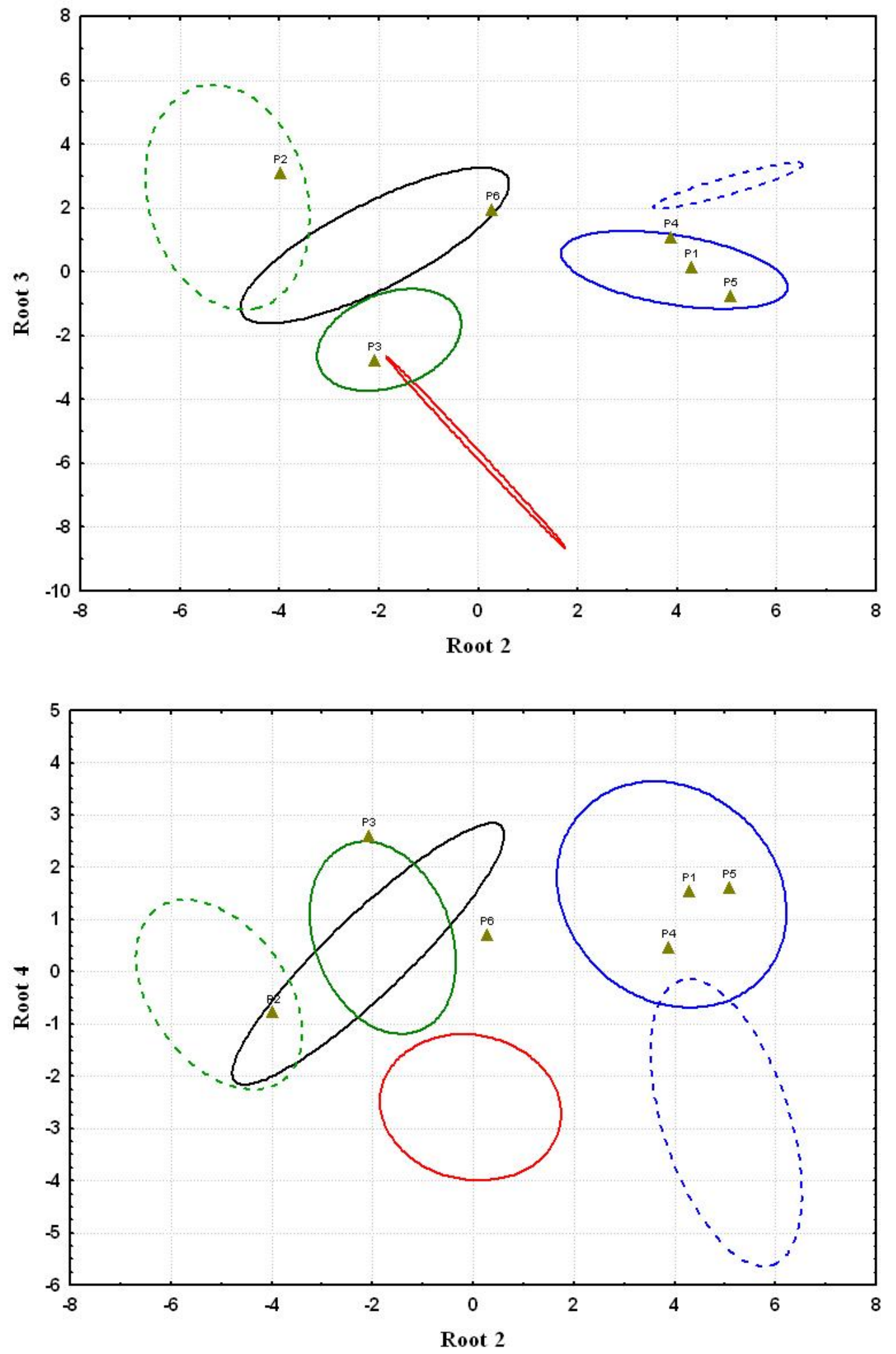

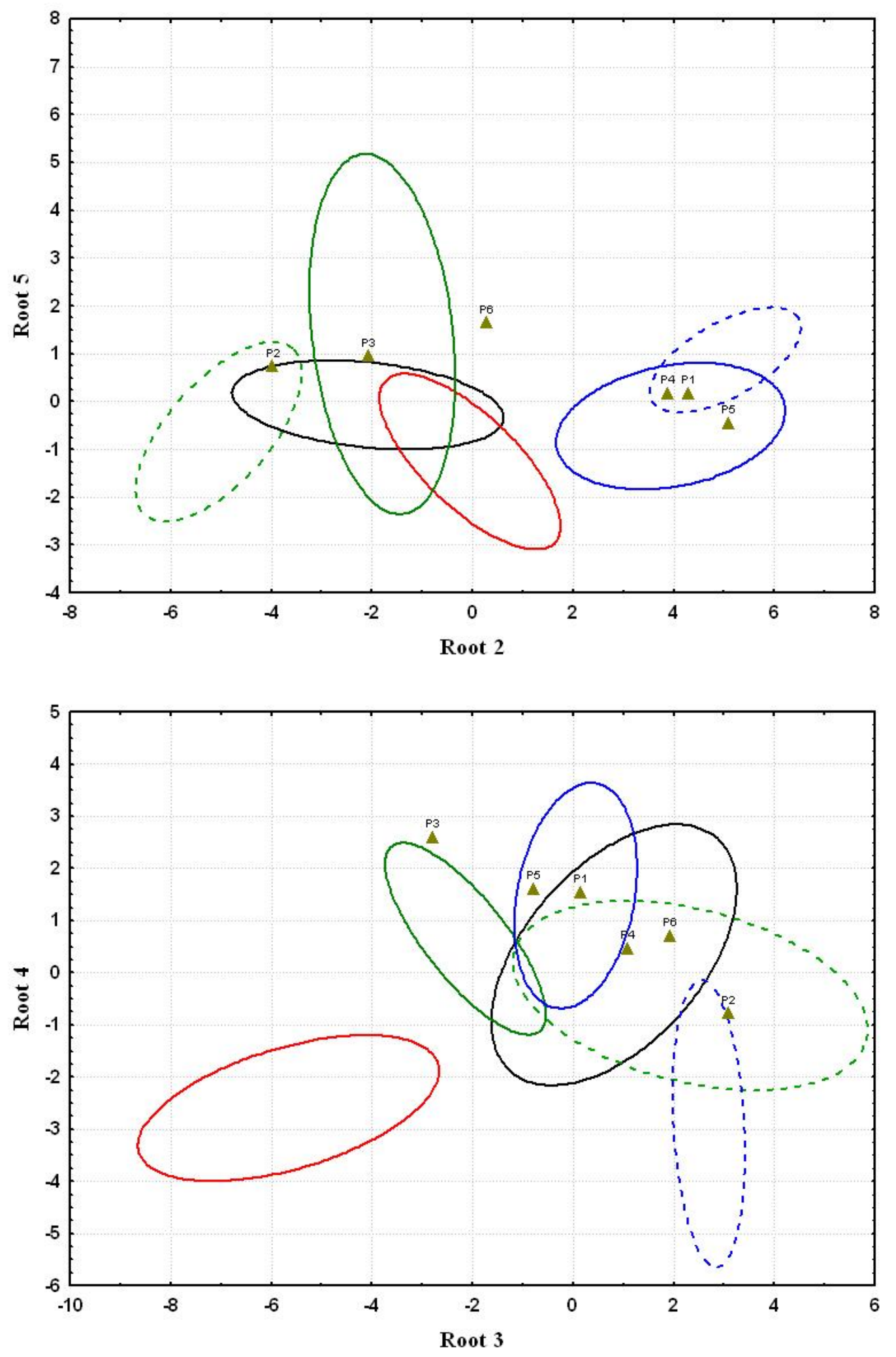

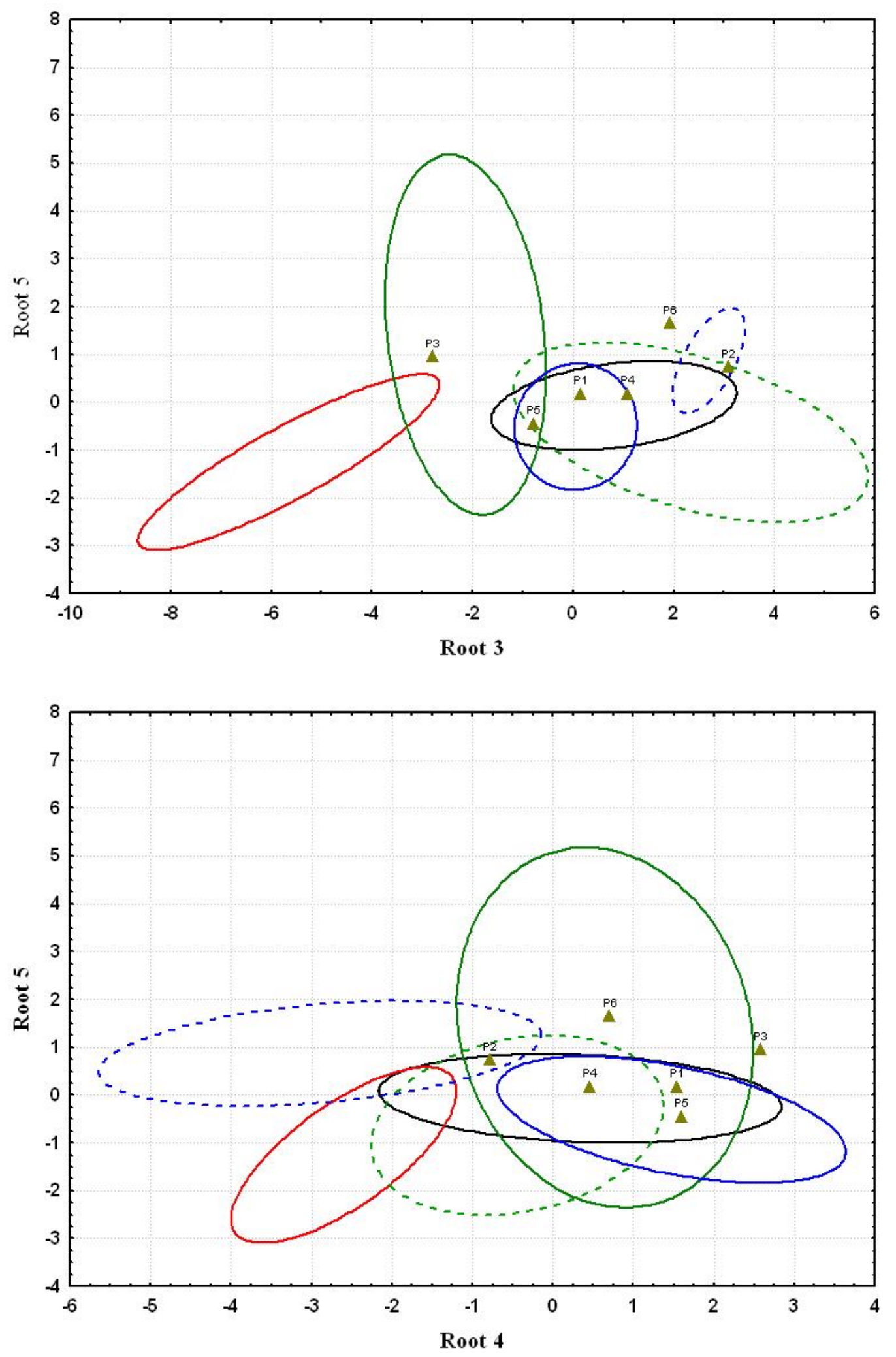


\section{Six-Category Model, Gunter Element Set}

Element Set:

$\mathrm{SiO}_{2}, \mathrm{TiO}_{2}, \mathrm{Al}_{2} \mathrm{O} 3, \mathrm{FeO}, \mathrm{MnO}, \mathrm{CaO}, \mathrm{K}_{2} \mathrm{O}, \mathrm{Ba}, \mathrm{Cr}, \mathrm{Cu}, \mathrm{Ga}, \mathrm{Ni}, \mathrm{Sc}, \mathrm{V}, \mathrm{Zn}$

Categories:

\begin{tabular}{|l|c|l|c|}
\hline \multicolumn{1}{|c|}{ Category } & Abbreviation & \multicolumn{1}{|c|}{ Sample IDs } & $\begin{array}{c}\text { No. } \\
\text { Samples }\end{array}$ \\
\hline South Africa & SA & GS-1, GS-3, GS-13, GS-17, GS-18,PVC1, PVC2, PVC3 & 8 \\
\hline China & CH & GS-7, GS-12, GS-16 & 3 \\
\hline $\begin{array}{l}\text { South Carolina } \\
\text { Group 1 }\end{array}$ & SC-1 & SC4, SC5, SC6, SC9, SC10, SC11 & 6 \\
\hline $\begin{array}{l}\text { South Carolina } \\
\text { Group 2 }\end{array}$ & SC-2 & GS-11, SG-15, SC2, SC3, SC7, SC8, PVC5 & 7 \\
\hline $\begin{array}{l}\text { Libby } \\
\text { Group 1 }\end{array}$ & L-1 & 1A, 4A, 9A, 10A & 4 \\
\hline Libby \\
Group 2 & L-2 & GS-2, GS-4, GS-10, 2A, 3A, 5A, 6A, 7A, 8A, 11A & 10 \\
\hline \multicolumn{1}{|c|}{ Total Number of Samples = } \\
\hline
\end{tabular}

Discriminant Function Analysis.

\begin{tabular}{|c|c|c|c|c|c|c|c|}
\hline \multirow{2}{*}{$\begin{array}{l}\mathrm{N}=38 \\
\text { Step }\end{array}$} & \multicolumn{7}{|c|}{$\begin{array}{l}\text { Discriminant Function Analysis Summary (fprinttraceln } 1) \\
\text { Step 8, N of vars in model: 8; Grouping: Category (6 grps) } \\
\text { Wilks' Lambda: } .00022 \text { approx. F }(40,111)=16.424 \text { p }<0.0000\end{array}$} \\
\hline & $\begin{array}{l}\text { Element } \\
\text { Added }\end{array}$ & Wilks' $\Lambda$ & $\begin{array}{c}\text { Wilks' } \\
\text { Partial } \Lambda \\
\end{array}$ & F-Remove & p-Level & Tolerance & $\begin{array}{c}\text { Correlated Variables } \\
\text { Removed }\end{array}$ \\
\hline 1 & V & 0.000561 & 0.3988 & 7.54 & 1.9616E-04 & 0.6983 & $\mathrm{TiO}_{2}, \mathrm{MnO}$ \\
\hline 2 & $\mathrm{Zn}$ & 0.000637 & 0.3509 & 9.25 & 4.3912E-05 & 0.3720 & $\mathrm{Cu}$ \\
\hline 3 & $\mathrm{Ni}$ & 0.000811 & 0.2757 & 13.14 & 2.4952E-06 & 0.5589 & none \\
\hline 4 & $\mathrm{SiO}_{2}$ & 0.000541 & 0.4135 & 7.09 & 2.9849E-04 & 0.4953 & none \\
\hline 5 & $\mathrm{Ga}$ & 0.000511 & 0.4381 & 6.41 & 5.8133E-04 & 0.3700 & $\mathrm{Al}_{2} \mathrm{O}_{3}$ \\
\hline 6 & $\mathrm{FeO}$ & 0.000538 & 0.4155 & 7.03 & 3.1633E-04 & 0.2097 & none \\
\hline 7 & Sc & 0.000402 & 0.5564 & 3.99 & 8.5234E-03 & 0.5594 & none \\
\hline 8 & $\mathrm{Ba}$ & 0.000351 & 0.6379 & 2.84 & 3.6556E-02 & 0.5464 & none \\
\hline
\end{tabular}

\begin{tabular}{|c|c|c|c|c|c|c|}
\hline \multirow{2}{*}{$\begin{array}{l}\mathrm{n}=38 \\
\text { Element }\end{array}$} & \multicolumn{6}{|c|}{$\begin{array}{l}\text { Variables currently not in the model (fprinttraceln1) } \\
\text { Df for all F-tests: } 5,24\end{array}$} \\
\hline & Wilks' $\Lambda$ & $\begin{array}{c}\text { Wilks' } \\
\text { Partial } \Lambda\end{array}$ & $\begin{array}{l}\text { F to } \\
\text { Enter }\end{array}$ & p-level & Toler. & 1-Toler. \\
\hline $\mathrm{TiO}_{2}$ & 0.000063 & 0.2833 & 12.1432 & 0.00001 & 0.2007 & 0.7993 \\
\hline $\mathrm{Al}_{2} \mathrm{O}_{3}$ & 0.000194 & 0.8668 & 0.7376 & 0.60268 & 0.1950 & 0.8050 \\
\hline $\mathrm{MnO}$ & 0.000135 & 0.6042 & 3.1448 & 0.02532 & 0.7385 & 0.2615 \\
\hline
\end{tabular}




\begin{tabular}{|c|rrrrrr|}
\hline $\mathrm{CaO}$ & 0.000165 & 0.7391 & 1.6947 & 0.17425 & 0.7789 & 0.2211 \\
$\mathrm{~K}_{2} \mathrm{O}$ & 0.000076 & 0.3393 & 9.3470 & 0.00005 & 0.0788 & 0.9212 \\
$\mathrm{Cr}$ & 0.000156 & 0.6992 & 2.0648 & 0.10532 & 0.4049 & 0.5951 \\
$\mathrm{Cu}$ & 0.000182 & 0.8152 & 1.0884 & 0.39208 & 0.4875 & 0.5125 \\
\hline \multicolumn{7}{|c|}{ Squared Mahalanobis Distances (fprinttraceln1) } \\
\hline Category & \multicolumn{1}{|c|}{ CH } & \multicolumn{1}{|c|}{ L1 } & \multicolumn{1}{c}{ L2 } & \multicolumn{1}{c|}{ SA } & \multicolumn{1}{c|}{ SC1 } & \multicolumn{1}{c|}{ SC2 } \\
\hline CH & 0.0000 & 76.6194 & 60.1577 & 125.8475 & 62.8720 & 25.3773 \\
L1 & 76.6194 & 0.0000 & 24.3657 & 78.7953 & 64.8621 & 54.9905 \\
L2 & 60.1577 & 24.3657 & 0.0000 & 93.7229 & 47.1244 & 34.8303 \\
SA & 125.8475 & 78.7953 & 93.7229 & 0.0000 & 183.3785 & 121.4912 \\
SC1 & 62.8720 & 64.8621 & 47.1244 & 183.3785 & 0.0000 & 30.1417 \\
SC2 & 25.3773 & 54.9905 & 34.8303 & 121.4912 & 30.1417 & 0.0000 \\
\hline
\end{tabular}

\begin{tabular}{|c|r|r|r|r|r|r|}
\cline { 2 - 8 } \multicolumn{1}{c|}{} & \multicolumn{7}{c|}{ F-values; df $=8,26$ (fprinttraceln1) } \\
\hline Category & CH & \multicolumn{1}{c|}{ L1 } & \multicolumn{1}{c|}{ L2 } & SA & SC1 & \multicolumn{1}{c|}{ SC2 } \\
\hline CH & & 12.827 & 13.557 & 26.814 & 12.280 & 5.204 \\
L1 & 12.827 & & 6.798 & 20.520 & 15.202 & 13.670 \\
L2 & 13.557 & 6.798 & & 40.678 & 17.257 & 14.006 \\
SA & 26.814 & 20.520 & 40.678 & & 61.399 & 44.294 \\
SC1 & 12.280 & 15.202 & 17.257 & 61.399 & & 9.510 \\
SC2 & 5.204 & 13.670 & 14.006 & 44.294 & 9.510 & \\
\hline
\end{tabular}

\begin{tabular}{|c|c|c|c|c|c|c|}
\hline & \multicolumn{6}{|c|}{ p-levels (fprinttraceln1) } \\
\hline Category & $\mathrm{CH}$ & L1 & L2 & SA & SC1 & SC2 \\
\hline $\mathrm{CH}$ & \multicolumn{6}{|c|}{ 2.8283E-07 1.6357E-07 1.1228E-10 4.3294E-07 5.9904E-04 } \\
\hline L1 & 2.8283E-07 & & $8.1529 \mathrm{E}-05$ & $2.1758 \mathrm{E}-09$ & 5.1483E-08 & $1.5066 \mathrm{E}-07$ \\
\hline L2 & 1.6357E-07 & $8.1529 E-05$ & & $9.0011 \mathrm{E}-13$ & $1.3824 \mathrm{E}-08$ & 1.1813E-07 \\
\hline SA & $1.1228 \mathrm{E}-10$ & $2.1758 \mathrm{E}-09$ & $9.0011 \mathrm{E}-13$ & & $6.3547 \mathrm{E}-15$ & $3.2738 \mathrm{E}-13$ \\
\hline SC1 & 4.3294E-07 & $5.1483 E-08$ & $1.3824 \mathrm{E}-08$ & 6.3547E-15 & & 4.7395E-06 \\
\hline Sc2 & 5.9904E-04 & 1.5066E-07 & 1.1813E-07 & $3.2738 \mathrm{E}-13$ & 4.7395E-06 & \\
\hline
\end{tabular}

\begin{tabular}{|c|c|c|c|c|c|c|c|c|c|c|c|}
\hline & \multicolumn{11}{|c|}{ Summary of Stepwise Analysis (fprinttraceln1) } \\
\hline \begin{tabular}{|c|} 
Variable \\
Enterl \\
Remove
\end{tabular} & Step & $\begin{array}{c}\mathrm{F} \text { to } \\
\text { enterl } \\
\text { remove }\end{array}$ & df 1 & df 2 & p-level & $\begin{array}{c}\text { No. of } \\
\text { vars. } \\
\text { In Model }\end{array}$ & Lambda & F-value & df 1 & df 2 & p-level \\
\hline V-(E) & 1 & 59.974 & 5 & 32 & $2.609 \mathrm{E}-15$ & 1 & 0.096424 & 59.974 & 5 & 32 & $2.609 \mathrm{E}-15$ \\
\hline$Z n-(E)$ & 2 & 18.892 & 5 & 31 & 1.347E-08 & 2 & 0.023825 & 33.967 & 10 & 62 & $1.914 \mathrm{E}-21$ \\
\hline $\mathrm{Ni}-(\mathrm{E})$ & 3 & 14.464 & 5 & 30 & 3.094E-07 & 3 & 0.006985 & 27.953 & 15 & 83 & $3.486 \mathrm{E}-26$ \\
\hline $\mathrm{SiO}_{2}-(\mathrm{E})$ & 4 & 13.946 & 5 & 29 & $5.601 \mathrm{E}-07$ & 4 & 0.002052 & 26.531 & 20 & 97 & $1.046 \mathrm{E}-30$ \\
\hline Ga-(E) & 5 & 5.726 & 5 & 28 & $9.252 \mathrm{E}-04$ & 5 & 0.001015 & 22.773 & 25 & 106 & $0.000 \mathrm{E}+00$ \\
\hline $\mathrm{FeO}-(\mathrm{E})$ & 6 & 3.665 & 5 & 27 & 1.166E-02 & 6 & 0.000604 & 19.719 & 30 & 110 & $0.000 \mathrm{E}+00$ \\
\hline Sc-(E) & 7 & 3.763 & 5 & 26 & 1.072E-02 & 7 & 0.000351 & 17.977 & 35 & 112 & $0.000 \mathrm{E}+00$ \\
\hline Ba-(E) & 8 & 2.838 & 5 & 25 & $3.656 \mathrm{E}-02$ & 8 & 0.000224 & 16.424 & 40 & 112 & $0.000 \mathrm{E}+00$ \\
\hline
\end{tabular}




\begin{tabular}{|c|r|r|r|r|r|r|}
\hline \multicolumn{6}{|c|}{ Chi-Square Tests with Successive Roots Removed (fprinttraceln1) } \\
\hline $\begin{array}{c}\text { Roots } \\
\text { Removed }\end{array}$ & $\begin{array}{c}\text { Eigen- } \\
\text { value }\end{array}$ & $\begin{array}{c}\text { Canonical } \\
\text { R }\end{array}$ & $\begin{array}{c}\text { Wilks' } \\
\text { Lambda }\end{array}$ & $\begin{array}{c}\text { Chi-Sqr. } \\
\text { df }\end{array}$ & \multicolumn{1}{c|}{ p-level } \\
\hline 0 & 23.48 & 0.9794 & 0.000224 & 252.16 & 40 & $0.000 \mathrm{E}+00$ \\
1 & 6.45 & 0.9304 & 0.005474 & 156.23 & 28 & $0.000 \mathrm{E}+00$ \\
2 & 2.91 & 0.8628 & 0.040770 & 95.99 & 18 & $1.193 \mathrm{E}-12$ \\
3 & 1.85 & 0.8057 & 0.159561 & 55.06 & 10 & $3.078 \mathrm{E}-08$ \\
4 & 1.20 & 0.7384 & 0.454804 & 23.64 & 4 & $9.445 \mathrm{E}-05$ \\
\hline
\end{tabular}

\begin{tabular}{|c|c|c|c|c|c|c|c|c|c|c|c|}
\hline \multirow[b]{2}{*}{ Variable } & \multicolumn{5}{|c|}{$\begin{array}{l}\text { Raw Coefficients (fprinttraceln1) } \\
\text { for Canonical Variables }\end{array}$} & & \multicolumn{5}{|c|}{$\begin{array}{l}\text { Standardized Coefficients (fprinttraceln1) } \\
\text { for Canonical Variables }\end{array}$} \\
\hline & oot 1 & Root 2 & Root 3 & Root 4 & Root 5 & ariab & Root 1 & Root 2 & Root 3 & Root 4 & Root 5 \\
\hline $\mathbf{v}$ & -3.0005 & 0.94179 & 0.0305 & -1.6200 & -0.6251 & $\mathbf{V}$ & -0.82750 & 0.259732 & 0.008418 & -0.44 & -0.1 \\
\hline $\mathrm{Zn}$ & 354 & 5.43680 & -1.2514 & 0.3439 & -3.7684 & $\mathrm{Zn}$ & 0.22920 & 1.203546 & -0.277030 & 0.076131 & -0.834210 \\
\hline $\mathrm{Ni}$ & -1.4189 & 0.05000 & 2.3094 & 0.3458 & 27 & $\mathrm{Ni}$ & -0.62775 & 0.022123 & 1.021733 & 004 & 012 \\
\hline $\mathrm{SiO}_{2}$ & -15.4169 & 1.46894 & -10.1807 & 3.3974 & 20.4904 & $\mathrm{SiO}_{2}$ & -0.71967 & 0.068571 & -0.475241 & 596 & 506 \\
\hline Ga & 9005 & -2.16669 & 02 & 5.3064 & 4 & Ga & 930 & -0.450781 & 7746 & 000 & 385 \\
\hline $\mathrm{FeO}$ & 3102 & -5.72939 & 481 & 3.6431 & 5 & $\mathrm{FeO}$ & -1.15808 & -0.907649 & 0.482871 & 0.5 & $0 . \varepsilon$ \\
\hline & & -1 & & 23 & & & & -0. & & & \\
\hline $\mathrm{Ba}$ & & & & & & & & -0.318948 & 7371 & -0.10 & -0.5068 \\
\hline Cons & 293 & -8.63200 & 07 & -32.2415 & -83.6 & $c$ & & --- & & & \\
\hline & & & & & & & 23. & 47648 & & 345 & \\
\hline Cum.Prob. & 0.6542 & "0.83384 & 0.9150 & "0.9666 & 1.0000 & Cum.Prob & "0.65417 & 0.833840 & 0.915032 & 0.966595 & 1.000000 \\
\hline
\end{tabular}

\begin{tabular}{|c|c|c|c|c|c|}
\hline \multirow[b]{2}{*}{ Variable } & \multicolumn{5}{|c|}{$\begin{array}{l}\text { Factor Structure Matrix (fprinttraceln1) } \\
\text { Correlations Variables - Canonical Roots } \\
\text { (Pooled-within-groups correlations) }\end{array}$} \\
\hline & Root 1 & Root 2 & Root 3 & Root 4 & Root 5 \\
\hline $\mathbf{V}$ & -0.621279 & 0.137904 & -0.072936 & 0.134725 & -0.339426 \\
\hline $\mathrm{Zn}$ & -0.171077 & 0.592799 & -0.041899 & 0.645423 & -0.355453 \\
\hline $\mathrm{Ni}$ & 0.025481 & 0.332356 & 0.749675 & -0.041160 & 0.400600 \\
\hline $\mathrm{SiO}_{2}$ & -0.068055 & 0.303966 & -0.373995 & -0.356532 & 0.673089 \\
\hline $\mathbf{G a}$ & -0.085906 & $-0.01 \varepsilon$ & -0.01 & 0.81 & -0.153645 \\
\hline $\mathrm{FeO}$ & -0.194238 & 0.018507 & 0.070432 & 0.473489 & -0.330083 \\
\hline Sc & -0.207276 & -0.303071 & -0.317602 & -0.212157 & 0.079862 \\
\hline $\mathrm{Ba}$ & -0.217496 & -0.326132 & -0.009081 & 0.245747 & -0.393787 \\
\hline
\end{tabular}

\begin{tabular}{|c|r|r|r|r|r|}
\cline { 2 - 6 } \multicolumn{1}{c|}{} & \multicolumn{5}{c|}{ Means of Canonical Variables (fprinttraceln1) } \\
\hline Category & \multicolumn{1}{c|}{ Root 1 } & \multicolumn{1}{c|}{ Root 2 } & \multicolumn{1}{c|}{ Root 3 } & \multicolumn{1}{c|}{ Root 4 } & \multicolumn{1}{c|}{ Root 5 } \\
\hline CH & -1.93534 & 4.36356 & 2.09126 & -1.97015 & -1.93182 \\
L1 & 0.72577 & -2.80911 & -0.89469 & -3.02662 & 0.90696 \\
L2 & -0.78920 & -2.60670 & 1.61550 & 0.74891 & -0.30707 \\
SA & 7.88935 & 0.92612 & -0.80078 & 0.48831 & -0.17141 \\
SC1 & -5.46528 & -0.08371 & -2.69821 & 0.56622 & -0.80886 \\
SC2 & -2.78974 & 2.47229 & 0.53507 & 0.46057 & 1.63753 \\
\hline
\end{tabular}




\begin{tabular}{|c|c|c|c|c|c|c|}
\hline & \multicolumn{6}{|c|}{ Unstandardized Canonical Scores (fprinttraceln1) } \\
\hline Samples & Group & Root 1 & Root 2 & Root 3 & Root 4 & Root 5 \\
\hline CH GS-7 & $\mathrm{CH}$ & -0.69734 & 3.98224 & 1.39224 & -2.07189 & -1.92511 \\
\hline CH GS-12 & $\mathrm{CH}$ & -2.80544 & 4.92707 & 2.80143 & -3.19405 & -2.91827 \\
\hline CH GS-16 & $\mathrm{CH}$ & -2.30323 & 4.18138 & 2.08011 & -0.64452 & -0.95208 \\
\hline L 1A & L1 & 0.85059 & -2.87445 & -1.95986 & -4.67919 & 1.54702 \\
\hline L 4A & L1 & 1.17111 & -3.25860 & 0.05479 & -0.69237 & 1.14501 \\
\hline L 9A & L1 & 0.70191 & -2.62043 & -0.01995 & -1.89223 & 0.86325 \\
\hline L10A & L1 & 0.17947 & -2.48295 & -1.65371 & -4.84269 & 0.07255 \\
\hline L GS-2 & L2 & -0.94188 & -1.59254 & 1.19176 & -0.01734 & 0.11015 \\
\hline L GS-4 & L2 & -1.52059 & -1.54017 & 1.42653 & 0.91023 & -0.02837 \\
\hline L GS-10 & L2 & -0.87796 & -2.05106 & 1.17132 & 0.89274 & 0.50140 \\
\hline L A & L2 & -0.73677 & -2.80387 & 1.71755 & 0.93435 & -0.79515 \\
\hline L $3 A$ & L2 & -1.35322 & -4.05594 & 2.00395 & 1.13280 & 0.69341 \\
\hline L 5A & L2 & -0.29344 & -3.62641 & 2.30719 & 0.31979 & -0.66847 \\
\hline L 6A & L2 & -1.05007 & -4.32207 & 1.92202 & 0.98967 & -0.61465 \\
\hline L 7A & L2 & -0.47145 & -3.35683 & 2.34289 & -0.00796 & -0.07080 \\
\hline L 8A & L2 & -0.74640 & -2.83106 & 1.61214 & 1.13961 & -0.89684 \\
\hline L 11A & L2 & 0.09975 & 0.11293 & 0.45964 & 1.19524 & -1.30135 \\
\hline SA GS-3 & SA & 7.30295 & 2.52794 & -0.17177 & -0.80514 & -1.43410 \\
\hline SA GS-13 & SA & 6.95744 & 1.24195 & -0.02376 & 0.76089 & -0.18323 \\
\hline SA GS-17 & SA & 6.49393 & 1.11144 & -0.89435 & 0.56262 & 0.15325 \\
\hline SA GS-18 & SA & 7.14187 & 0.87245 & -1.12079 & 0.53287 & 0.01747 \\
\hline SA PVC1 & SA & 11.01202 & -0.03535 & -0.80872 & 0.43928 & -0.89277 \\
\hline SA PVC2 & SA & 8.25028 & 0.06056 & -0.73314 & 0.56461 & -0.30206 \\
\hline SA PVC3 & SA & 8.62654 & 0.71439 & -0.49080 & 1.02777 & -0.26944 \\
\hline SA GS-1 & SA & 7.32978 & 0.91561 & -2.16291 & 360 & 1.53961 \\
\hline SC4 & SC1 & -5.37064 & -0.23251 & -2.65243 & 0.02531 & -0.08111 \\
\hline SC5 & SC1 & -6.20986 & 1.25413 & 0.41387 & 1.06703 & -0.84149 \\
\hline SC6 & SC1 & -5.25736 & -0.29902 & -2.75931 & 825 & 0.17735 \\
\hline SC9 & SC1 & -4.64061 & 1.00553 & -4.07946 & 5760 & -0.76264 \\
\hline SC10 & SC1 & -5.12602 & -0.52455 & -2.53132 & -0.78757 & -0.53038 \\
\hline SC11 & SC1 & -6.18717 & -1.70584 & -4.58060 & 1.02671 & -2.81488 \\
\hline SC GS-11 & SC2 & -1.67956 & 2.67393 & 0.13726 & 1.79500 & 0.62335 \\
\hline SC GS-15 & SC2 & -1.95203 & 2.85275 & 0.24562 & -0.05134 & 0.18703 \\
\hline SC2 & SC2 & -0.72003 & 3.12718 & 1.86623 & -1.04801 & 3.70678 \\
\hline SC3 & SC2 & -3.43839 & 1.72441 & 0.43102 & 946 & 3.17130 \\
\hline SC7 & SC2 & -3.61187 & 3.61608 & 0.29468 & 462 & 1.55684 \\
\hline SC8 & SC2 & -4.18832 & 2.12654 & -1.07308 & -0.13417 & 2.52124 \\
\hline SC PVC5 & SC2 & -3.93799 & 1.18515 & 1.84376 & -0.07158 & -0.30384 \\
\hline P1 & -- & -0.26156 & -2.06513 & 1.58420 & 594 & 0.05964 \\
\hline P2 & ---- & 8.69043 & -0.25506 & -1.03886 & -0.21658 & -1.18127 \\
\hline P3 & ---- & -2.35661 & 2.57015 & 1.54772 & 2.88720 & 0.16677 \\
\hline P4 & ---- & -0.74208 & -2.67744 & 0.97110 & 0.73297 & 0.45596 \\
\hline P5 & ---- & -0.04076 & -1.10566 & 1.32261 & 0.90582 & -0.58316 \\
\hline P6 & ---- & 3.99954 & -1.83539 & 1.88625 & -1.43582 & -0.55584 \\
\hline Li1UI & --- & -0.38495 & -2.46971 & 1.53000 & 1.08665 & -0.32298 \\
\hline Li2UI & ---- & 1.04362 & -1.50970 & 1.36524 & 0.73850 & -0.68913 \\
\hline at1UI & ---- & 0.04871 & -0.95002 & 1.20062 & 1.32636 & -0.91847 \\
\hline at2UI & ---- & 0.03762 & 0.00522 & 1.27250 & 1.06674 & -1.89720 \\
\hline at3UI & ---- & -0.27443 & 2.14973 & 0.38175 & 1.36762 & -2.56342 \\
\hline at4UI & ---- & 0.06580 & -2.04231 & 1.08686 & 2.77583 & 1.01735 \\
\hline ga1UI & ---- & 7.96570 & 1.02080 & -0.56321 & 0.97440 & -1.56908 \\
\hline ga2UI & ---- & 7.71552 & 1.02703 & -0.46388 & 1.43043 & -1.67518 \\
\hline ga3UI & ---- & 7.44537 & 1.16499 & -0.03826 & -0.08954 & -2.48223 \\
\hline ga4UI & ---- & 8.75772 & 1.07537 & 0.11699 & 0.54800 & -2.42305 \\
\hline ga5UI & ---- & 12.40554 & 2.42181 & 0.88815 & -3.81538 & -7.95268 \\
\hline ga6UI & -.-- & 6.89926 & 0.97805 & -0.31438 & 0.23141 & -2.23335 \\
\hline ga7UI & ---- & 8.62803 & 0.40633 & -0.26734 & 2.03683 & -1.00923 \\
\hline SA1UI & ---- & 19.57583 & -0.98666 & -0.91356 & 5.68981 & 0.78531 \\
\hline SC1UI & ---- & -0.99506 & 2.02520 & 0.70848 & 2.46516 & -0.16237 \\
\hline SC2UI & ---- & -0.91236 & 2.63376 & 0.54410 & 2.37406 & -0.20080 \\
\hline SC3UI & ---- & -2.21119 & 2.19307 & 1.33394 & -0.32004 & 1.00816 \\
\hline SC4UI & ---- & -3.15287 & 1.72153 & 1.22443 & 0.67283 & 2.10052 \\
\hline SC5UI & ---- & -5.14475 & 0.29400 & -2.56300 & 5.57109 & 3.87239 \\
\hline SC6UI & ---- & -3.90157 & 2.57179 & 1.36239 & 2.50417 & 1.58709 \\
\hline
\end{tabular}



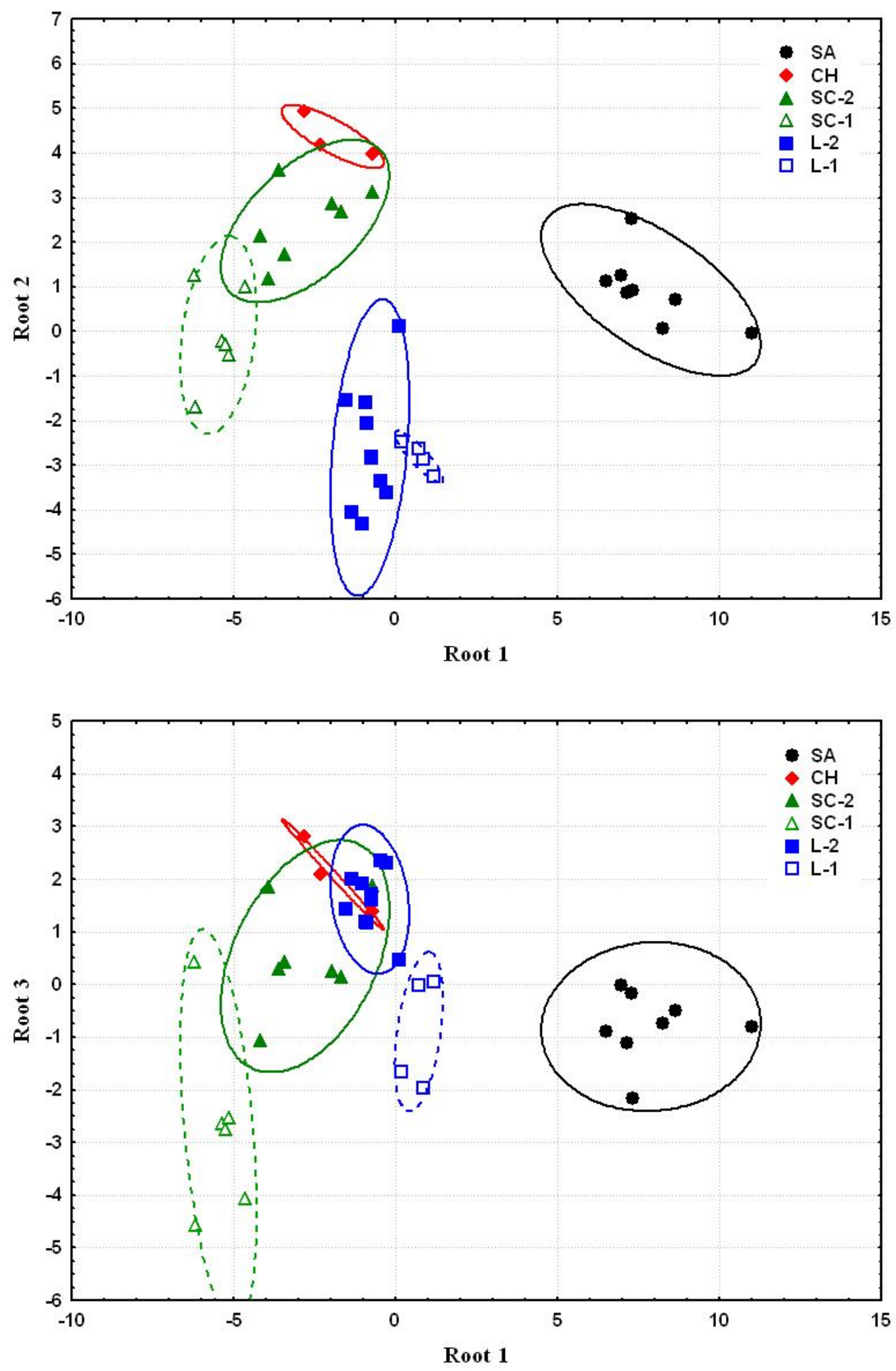

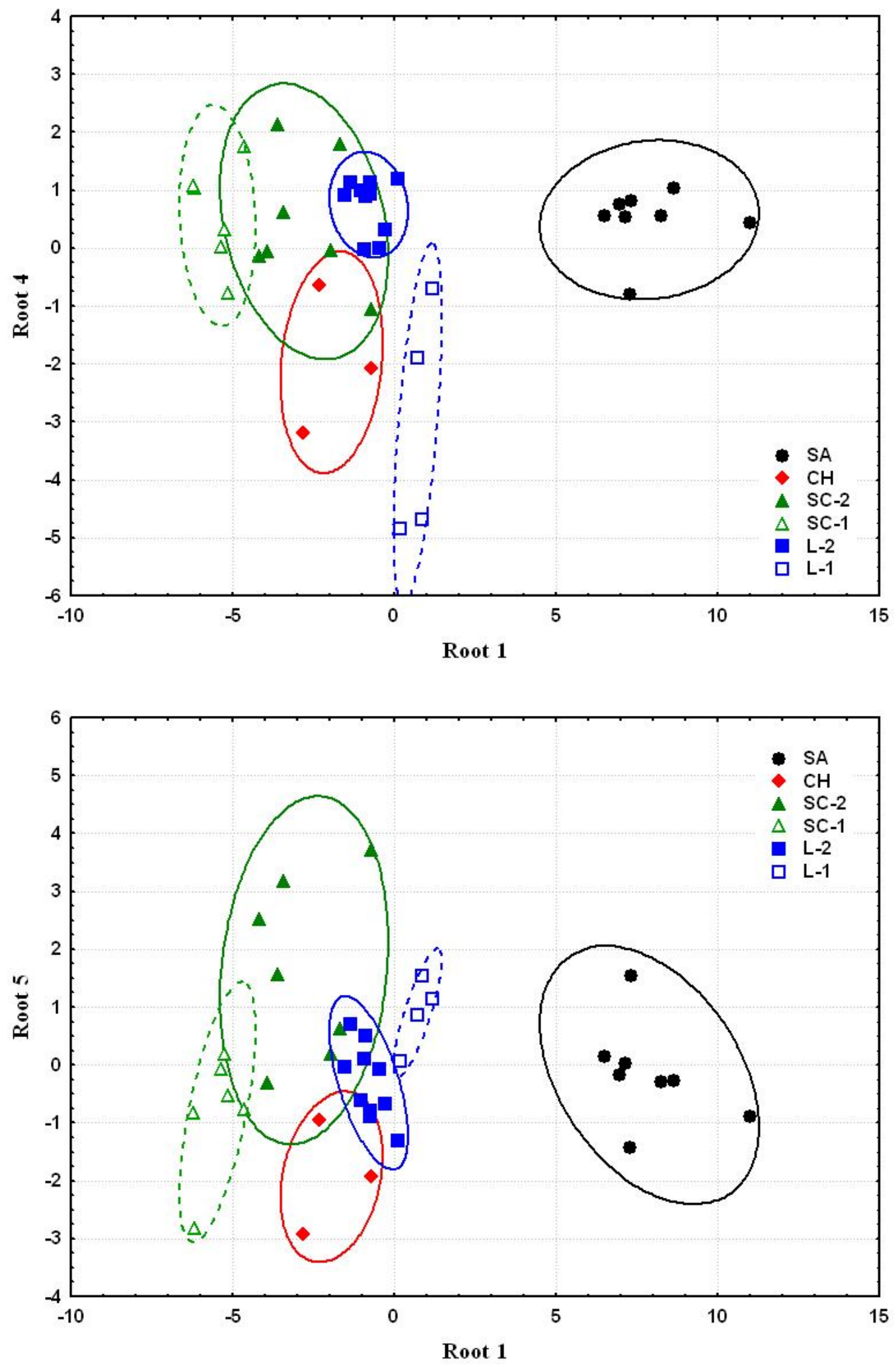

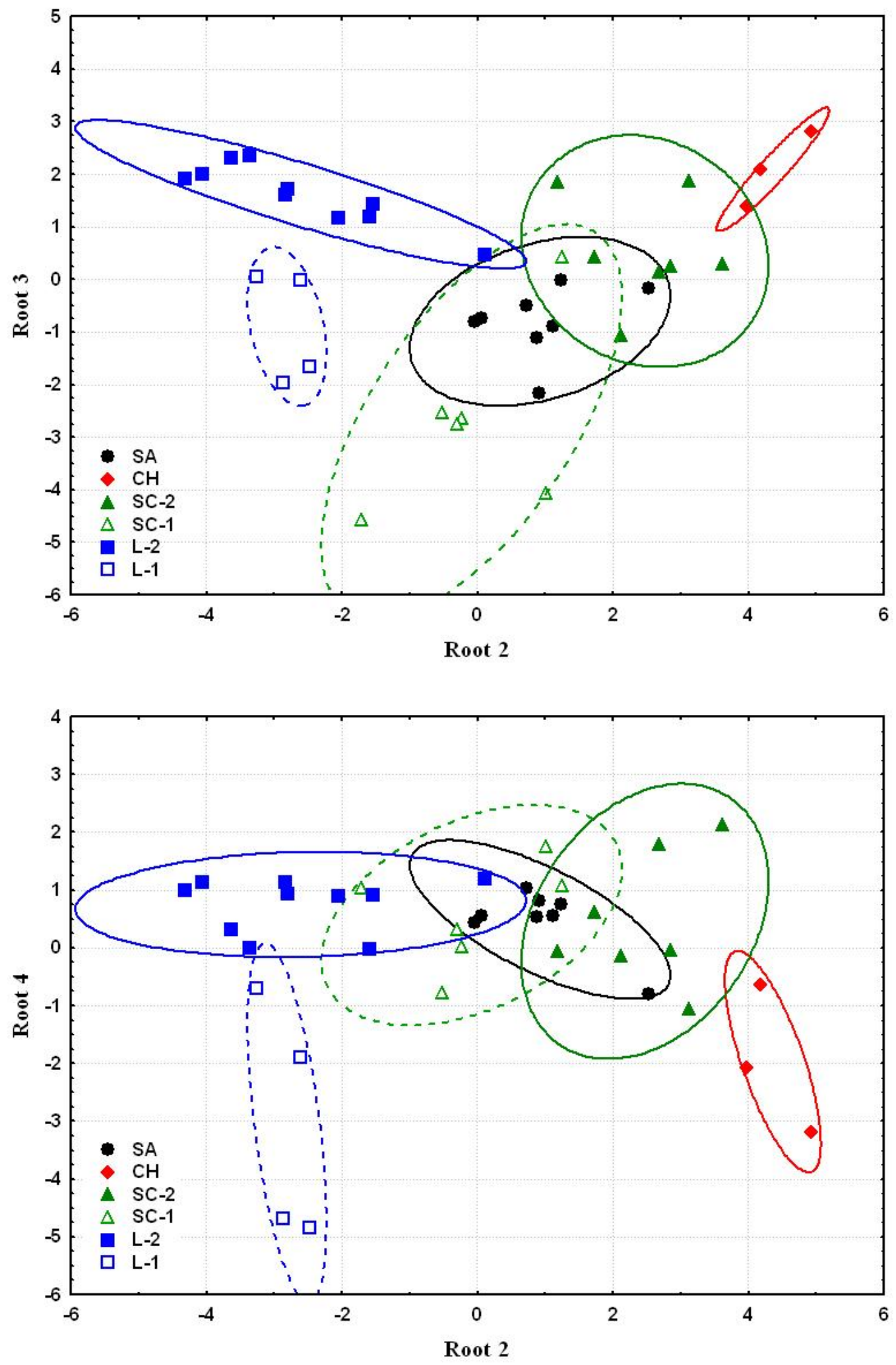

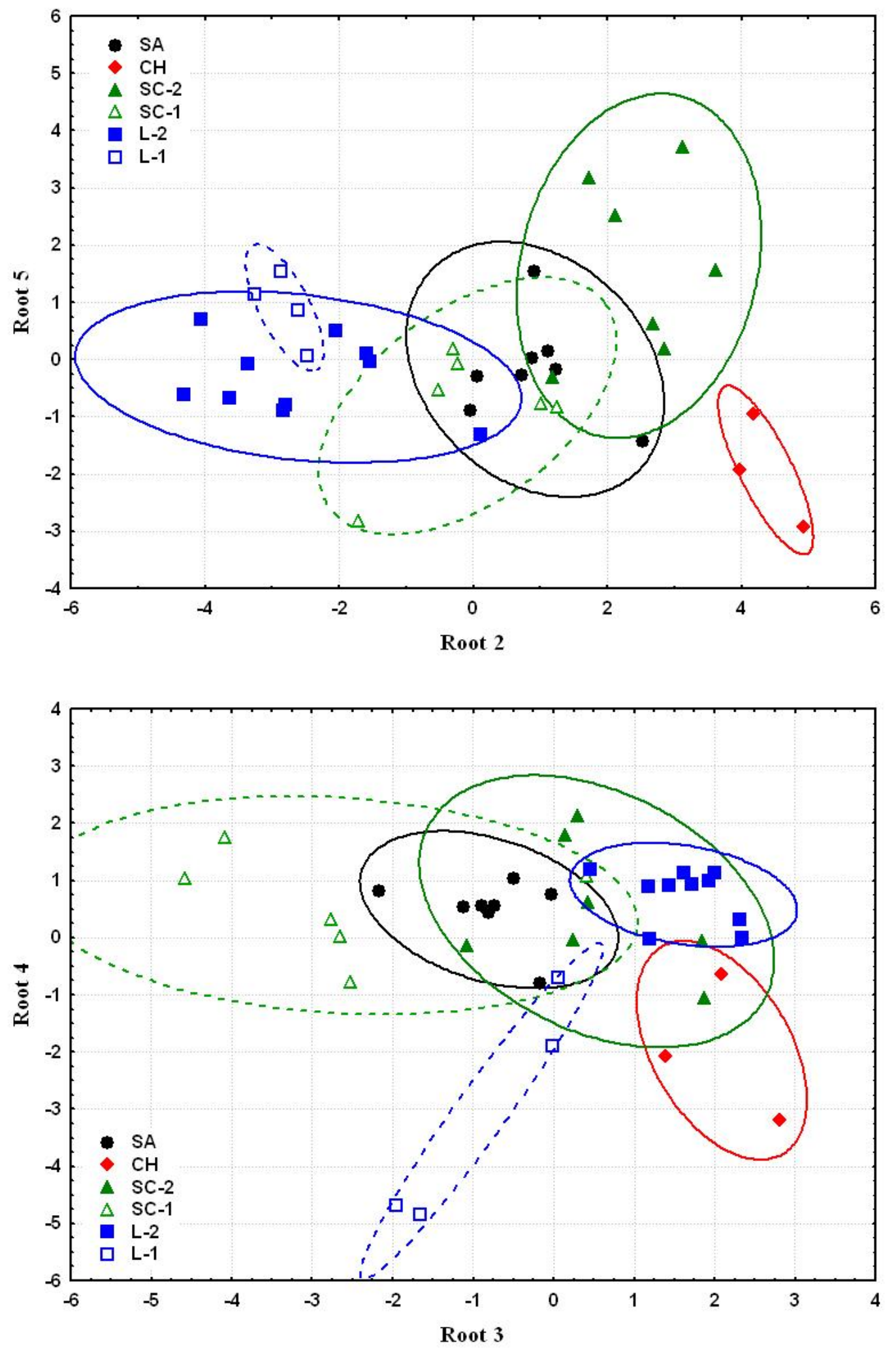

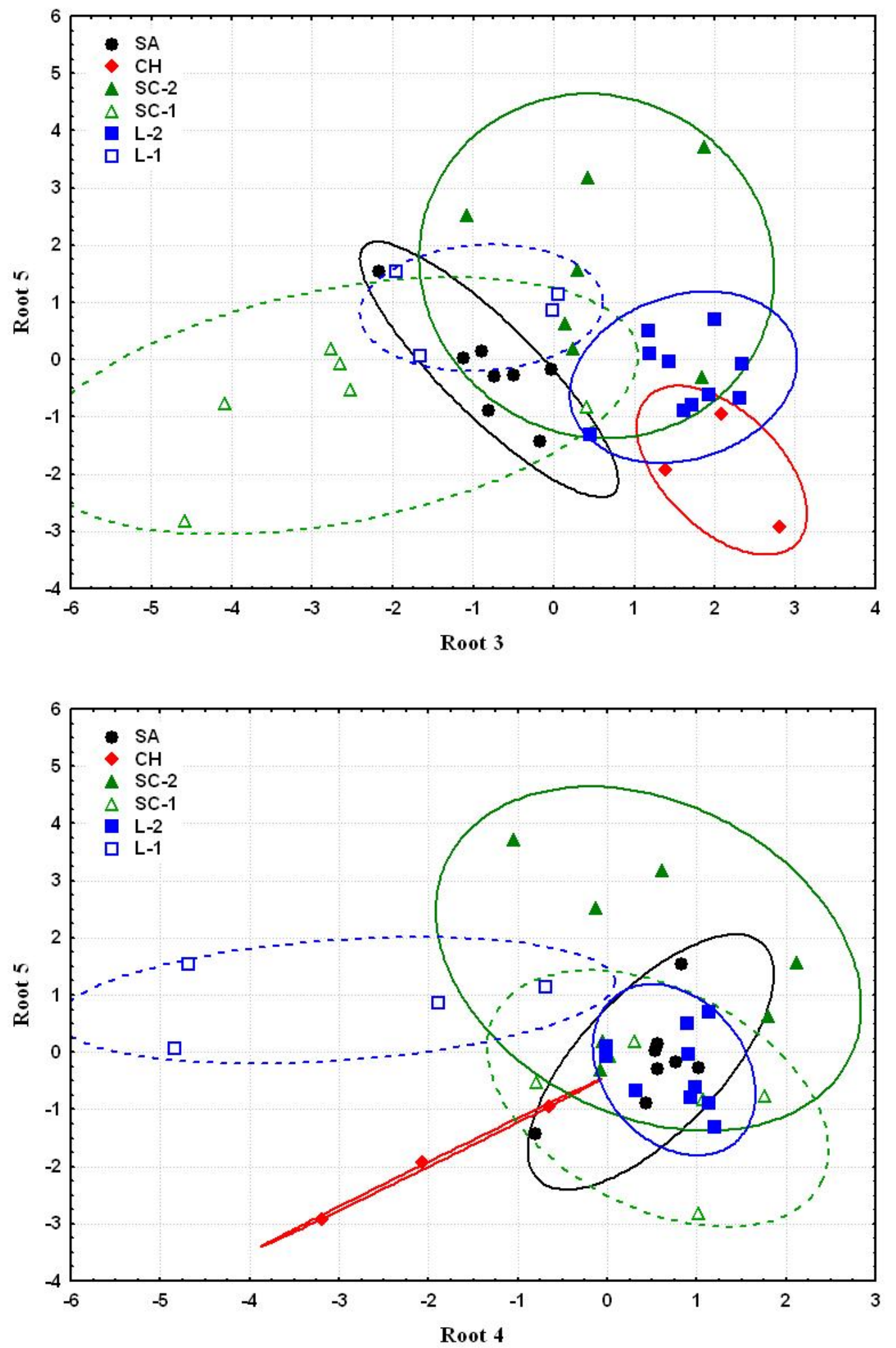


\section{Classification}

\begin{tabular}{|c|r|r|r|r|r|r|}
\cline { 2 - 8 } \multicolumn{1}{c|}{} & \multicolumn{6}{c|}{ Classification Functions; grouping: Category (fprinttraceln1) } \\
\hline & $\mathbf{C H}$ & \multicolumn{1}{c|}{ L1 } & \multicolumn{1}{c|}{ L2 } & \multicolumn{1}{c|}{ SA } & \multicolumn{1}{c|}{ SC1 } & \multicolumn{1}{c|}{ SC2 } \\
& $\mathbf{p = . 0 7 8 9 5}$ & $\mathbf{p}=\mathbf{1 0 5 2 6}$ & $\mathbf{p = . 2 6 3 1 6}$ & $\mathbf{p = . 2 1 0 5 3}$ & $\mathbf{p = . 1 5 7 8 9}$ & $\mathbf{p = . 1 8 4 2 1}$ \\
\hline $\mathbf{V}$ & 126.4 & 111.5 & 111.0 & 88.5 & 127.9 & 121.0 \\
$\mathbf{Z n}$ & -273.6 & -317.1 & -314.9 & -284.3 & -298.8 & -295.4 \\
$\mathbf{N i}$ & 197.6 & 189.3 & 197.2 & 179.5 & 193.4 & 199.8 \\
$\mathbf{S i O}{ }_{2}$ & 4273.9 & 4307.3 & 4293.4 & 4191.3 & 4402.2 & 4381.5 \\
$\mathbf{G a}$ & 231.0 & 260.5 & 269.6 & 276.4 & 260.3 & 263.9 \\
$\mathbf{F e O}$ & 1407.2 & 1431.2 & 1456.0 & 1364.7 & 1459.2 & 1447.7 \\
$\mathbf{S c}$ & 260.3 & 264.9 & 270.0 & 248.9 & 276.1 & 269.7 \\
$\mathbf{B a}$ & 104.6 & 102.4 & 105.1 & 92.7 & 108.2 & 102.6 \\
\hline \hline Constant & -10947.2 & -10891.9 & -10994.1 & -10241.3 & -11572.5 & -11426.6 \\
\hline
\end{tabular}

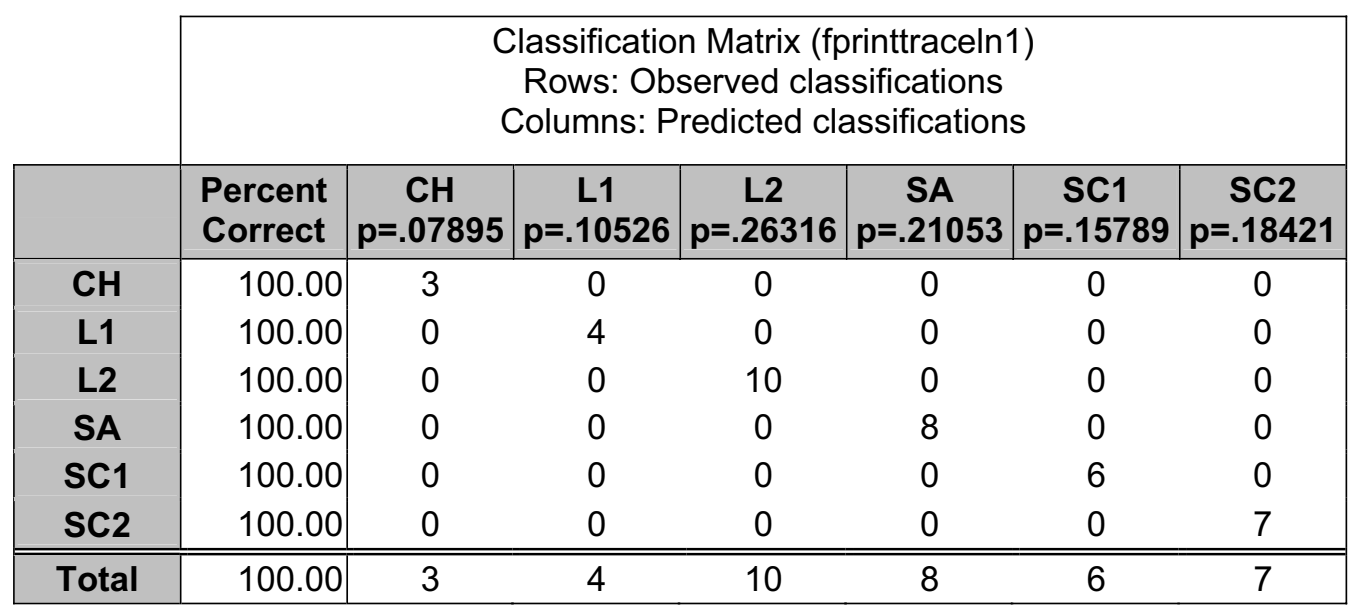




\begin{tabular}{|c|c|c|c|c|c|c|c|}
\hline \multirow[b]{2}{*}{ Samples } & \multicolumn{7}{|c|}{$\begin{array}{c}\text { Classification of Cases (fprinttraceln1) } \\
\text { Incorrect classifications are marked with * }\end{array}$} \\
\hline & $\begin{array}{l}\text { Observed } \\
\text { Classif. }\end{array}$ & $\begin{array}{c}1 \\
p=.07895\end{array}$ & $\begin{array}{c}2 \\
p=.10526\end{array}$ & $\begin{array}{c}3 \\
p=.26316\end{array}$ & $\begin{array}{c}4 \\
p=.21053\end{array}$ & $\begin{array}{c}5 \\
p=.15789\end{array}$ & $\begin{array}{c}6 \\
p=.18421\end{array}$ \\
\hline CH GS-7 & $\mathrm{CH}$ & $\mathrm{CH}$ & SC2 & $\mathrm{L} 2$ & L1 & $\mathrm{SC} 1$ & SA \\
\hline CH GS-12 & $\mathrm{CH}$ & $\mathrm{CH}$ & SC2 & SC1 & L2 & L1 & SA \\
\hline CH GS-16 & $\mathrm{CH}$ & $\mathrm{CH}$ & SC2 & $\mathrm{L} 2$ & SC1 & L1 & SA \\
\hline L 1A & L1 & L1 & L2 & $\mathrm{SC} 2$ & SC1 & SA & $\mathrm{CH}$ \\
\hline L 4A & L1 & L1 & L2 & $\mathrm{SC} 2$ & SA & $\mathrm{SC} 1$ & $\mathrm{CH}$ \\
\hline L 9A & L1 & L1 & L2 & $\mathrm{SC2}$ & SC1 & $\mathrm{CH}$ & SA \\
\hline L10A & L1 & L1 & L2 & $\mathrm{SC} 2$ & SC1 & $\mathrm{CH}$ & SA \\
\hline L GS-2 & L2 & L2 & L1 & $\mathrm{SC} 2$ & SC1 & $\mathrm{CH}$ & SA \\
\hline L GS-4 & L2 & L2 & $\mathrm{SC} 2$ & L1 & SC1 & $\mathrm{CH}$ & SA \\
\hline L GS-10 & L2 & L2 & L1 & $\mathrm{SC} 2$ & SC1 & $\mathrm{CH}$ & SA \\
\hline LA & L2 & L2 & L1 & $\mathrm{SC} 2$ & SC1 & $\mathrm{CH}$ & SA \\
\hline L $3 A$ & L2 & L2 & L1 & $\mathrm{SC} 2$ & SC1 & $\mathrm{CH}$ & SA \\
\hline L 5A & L2 & L2 & L1 & SC2 & SC1 & $\mathrm{CH}$ & SA \\
\hline L 6A & L2 & L2 & L1 & SC2 & SC1 & $\mathrm{CH}$ & SA \\
\hline L 7A & L2 & L2 & L1 & SC2 & SC1 & $\mathrm{CH}$ & SA \\
\hline L 8A & L2 & L2 & L1 & $\mathrm{SC} 2$ & SC1 & $\mathrm{CH}$ & SA \\
\hline L 11A & L2 & L2 & SC2 & L1 & $\mathrm{CH}$ & SC1 & SA \\
\hline SA GS-3 & SA & SA & L1 & $\mathrm{CH}$ & L2 & $\mathrm{SC} 2$ & $\mathrm{SC} 1$ \\
\hline SA GS-13 & SA & SA & L1 & L2 & SC2 & $\mathrm{CH}$ & SC1 \\
\hline SA GS-17 & SA & SA & L1 & L2 & SC2 & $\mathrm{CH}$ & SC1 \\
\hline SA GS-18 & SA & SA & L1 & L2 & SC2 & $\mathrm{CH}$ & SC1 \\
\hline SA PVC1 & SA & SA & L1 & L2 & $\mathrm{CH}$ & SC1 & SC2 \\
\hline SA PVC2 & SA & SA & L1 & L2 & SC2 & $\mathrm{CH}$ & SC1 \\
\hline SA PVC 3 & SA & SA & L1 & L2 & $\mathrm{SC} 2$ & $\mathrm{CH}$ & SC1 \\
\hline SA GS-1 & SA & SA & L1 & L2 & $\mathrm{SC} 2$ & $\mathrm{CH}$ & SC1 \\
\hline SC4 & SC1 & SC1 & SC2 & L2 & L1 & $\mathrm{CH}$ & SA \\
\hline SC5 & SC1 & SC1 & SC2 & $\mathrm{CH}$ & L2 & L1 & SA \\
\hline SC6 & SC1 & SC1 & $\mathrm{SC} 2$ & L2 & L1 & $\mathrm{CH}$ & SA \\
\hline SC9 & SC1 & SC1 & SC2 & L2 & $\mathrm{CH}$ & L1 & SA \\
\hline SC10 & SC1 & SC1 & SC2 & L2 & L1 & $\mathrm{CH}$ & SA \\
\hline SC11 & SC1 & SC1 & L2 & SC2 & L1 & $\mathrm{CH}$ & SA \\
\hline SC GS-11 & $\mathrm{SC} 2$ & $\mathrm{SC} 2$ & $\mathrm{CH}$ & L2 & $\mathrm{SC} 1$ & L1 & SA \\
\hline SC GS-15 & $\mathrm{SC} 2$ & SC2 & $\mathrm{CH}$ & SC1 & L2 & L1 & SA \\
\hline SC2 & SC2 & SC2 & $\mathrm{CH}$ & L2 & L1 & SC1 & SA \\
\hline SC3 & $\mathrm{SC} 2$ & $\mathrm{SC} 2$ & SC1 & L2 & $\mathrm{CH}$ & L1 & SA \\
\hline SC7 & SC2 & SC2 & SC1 & $\mathrm{CH}$ & $\mathrm{L} 2$ & L1 & SA \\
\hline SC8 & SC2 & SC2 & SC1 & $\mathrm{CH}$ & L2 & L1 & SA \\
\hline SC PVC5 & SC2 & $\mathrm{SC} 2$ & $\mathrm{CH}$ & L2 & SC1 & L1 & SA \\
\hline P1 & --- & L2 & $\mathrm{L} 1$ & $\mathrm{SC} 2$ & SC1 & $\mathrm{CH}$ & SA \\
\hline P2 & --- & SA & L1 & L2 & $\mathrm{CH}$ & $\mathrm{SC} 2$ & $\mathrm{SC} 1$ \\
\hline P3 & --- & SC2 & L2 & $\mathrm{CH}$ & SC1 & L1 & SA \\
\hline P4 & --- & L2 & L1 & $\mathrm{SC} 2$ & SC1 & $\mathrm{CH}$ & SA \\
\hline P5 & --- & L2 & $\mathrm{SC} 2$ & L1 & $\mathrm{CH}$ & SC1 & SA \\
\hline P6 & --- & L1 & L2 & SA & $\mathrm{SC} 2$ & $\mathrm{CH}$ & SC1 \\
\hline Li1UI & ---- & L2 & L1 & SC2 & SC1 & $\mathrm{CH}$ & SA \\
\hline Li2UI & ---- & L2 & L1 & SC2 & $\mathrm{CH}$ & SA & SC1 \\
\hline at1Ul & ---- & L2 & SC2 & L1 & $\mathrm{CH}$ & SC1 & SA \\
\hline at2UI & ---- & L2 & $\mathrm{SC} 2$ & $\mathrm{CH}$ & L1 & SC1 & SA \\
\hline at3UI & ---- & $\mathrm{CH}$ & SC2 & L2 & SC1 & L1 & SA \\
\hline at4UI & ---- & L2 & SC2 & L1 & SC1 & $\mathrm{CH}$ & SA \\
\hline ga1UI & --- & SA & L1 & L2 & $\mathrm{CH}$ & SC2 & SC1 \\
\hline ga2Ul & ---- & SA & L1 & L2 & $\mathrm{CH}$ & $\mathrm{SC} 2$ & $\mathrm{SC} 1$ \\
\hline ga3UI & ---- & SA & L1 & L2 & $\mathrm{CH}$ & SC2 & SC1 \\
\hline ga4Ul & ---- & SA & L1 & L2 & $\mathrm{CH}$ & $\mathrm{SC} 2$ & SC1 \\
\hline ga5UI & --- & SA & L1 & $\mathrm{CH}$ & L2 & $\mathrm{SC} 1$ & $\mathrm{SC} 2$ \\
\hline ga6Ul & ---- & SA & L1 & L2 & $\mathrm{CH}$ & $\mathrm{SC} 2$ & SC1 \\
\hline ga7UI & --- & SA & L2 & L1 & $\mathrm{SC} 2$ & $\mathrm{CH}$ & SC1 \\
\hline SA1UI & ---- & SA & $\mathrm{CH}$ & L1 & L2 & $\mathrm{SC} 1$ & $\mathrm{SC} 2$ \\
\hline SC1UI & --- & $\mathrm{SC} 2$ & L2 & $\mathrm{CH}$ & $\mathrm{SC} 1$ & L1 & SA \\
\hline SC2UI & ---- & SC2 & $\mathrm{CH}$ & L2 & SC1 & L1 & SA \\
\hline SC3UI & --- & $\mathrm{SC} 2$ & $\mathrm{CH}$ & L2 & SC1 & L1 & SA \\
\hline SC4UI & ---- & SC2 & L2 & SC1 & $\mathrm{CH}$ & L1 & SA \\
\hline SC5UI & --- & SC1 & SC2 & L2 & L1 & $\mathrm{CH}$ & SA \\
\hline Sc6UI & ---- & $\mathrm{SC} 2$ & SC1 & $\mathrm{CH}$ & L2 & L1 & SA \\
\hline
\end{tabular}




\begin{tabular}{|c|c|c|c|c|c|c|c|}
\hline \multirow[b]{2}{*}{ Samples } & \multicolumn{7}{|c|}{$\begin{array}{l}\text { Squared Mahalanobis Distances from Group Centroids (fprinttraceln1) } \\
\text { Incorrect classifications are marked with * }\end{array}$} \\
\hline & $\begin{array}{l}\text { Observed } \\
\text { Classif. }\end{array}$ & $\begin{array}{c}\mathrm{CH} \\
\mathrm{p}=.07895\end{array}$ & $\begin{array}{c}L 1 \\
p=.10526\end{array}$ & $\begin{array}{c}\mathrm{L} 2 \\
\mathrm{p}=.26316\end{array}$ & $\begin{array}{c}\text { SA } \\
p=.21053\end{array}$ & $\begin{array}{c}\text { SC1 } \\
p=.15789\end{array}$ & $\begin{array}{c}\text { SC2 } \\
p=.18421\end{array}$ \\
\hline CH GS-7 & $\mathrm{CH}$ & 4.3108 & 64.4435 & 56.1811 & 99.6442 & 66.3362 & 28.6322 \\
\hline CH GS-12 & $\mathrm{CH}$ & 7.9282 & 104.5179 & 88.4730 & 168.3455 & 4.8962 & 49.1524 \\
\hline CH GS-16 & $\mathrm{CH}$ & 3.6639 & 76.7996 & 51.7219 & 125.4557 & 53.2863 & 14.2501 \\
\hline L 1A & L1 & 102.4727 & 10.7648 & 54.9154 & 101.4578 & 87.7577 & 80.9594 \\
\hline L 4A & L1 & 86.1852 & 9.9982 & 14.0804 & 69.6966 & 70.2932 & 53.5250 \\
\hline L 9A & L1 & 68.8692 & 2.9524 & 14.1060 & 72.4469 & 61.3445 & 45.4330 \\
\hline L10A & L1 & 78.1214 & 5.4557 & 43.5319 & 100.7511 & 69.2241 & 69.2156 \\
\hline L GS-2 & L2 & 47.9616 & 21.0123 & 4.6999 & 91.3468 & 41.7619 & 25.6373 \\
\hline L GS-4 & L2 & 47.9221 & 28.9525 & 2.3462 & 100.3234 & 9572 & 22.0171 \\
\hline & L2 & 58.7036 & 24.4161 & & 91. & & 27.4732 \\
\hline L A & L2 & 62.9517 & $27 . \varepsilon$ & & & & 39.8685 \\
\hline L & L2 & 93.6771 & & & 125 & & \\
\hline L 5A & L2 & 73.7995 & & & & & 2811 \\
\hline L 6A & L2 & 87.2 & 32. & & 115. & & 56.9939 \\
\hline L & L2 & 69. & 22. & & & & 45. \\
\hline L 8A & L2 & 33 & 31. & & 98. & & 43.1708 \\
\hline L 11A & L2 & 37. & 35.3 & & 66. & & 24.9407 \\
\hline SA G & SA & 96.8068 & 84.0465 & 100. & & 17 & 114.7671 \\
\hline SA GS-13 & SA & 105.2012 & 72.9229 & 78. & 3.0 & 190 & 101.6247 \\
\hline SA GS-17 & SA & 102.6133 & 63.4013 & 74.7227 & 3.4093 & 149.9388 & 93.6034 \\
\hline SA GS-18 & SA & 115.6095 & 68.8763 & 83.2895 & 1.3454 & 163.6704 & 107.2119 \\
\hline C1 & SA & 204.2938 & 130.7741 & 154. & 13.2 & & 207.0001 \\
\hline C2 & SA & 899 & 69 & & & & 0486 \\
\hline & $\mathrm{S}$ & 27 & & & & & 72 \\
\hline & A & 140. & & & & & 24 \\
\hline $\mathbf{S}$ & SC1 & & & & & & \\
\hline $\mathbf{S}$ & & & & & & & 22 \\
\hline & & & & & & & \\
\hline & & & & & & & \\
\hline $\mathbf{s}$ & 1 & & & & & & 40 \\
\hline SC11 & 1 & 119 & 34 & & 23 & & 85.4688 \\
\hline SC GS-11 & SC2 & 378 & & & 102 & & 8.4348 \\
\hline SC GS-1 & SC2 & 19.2423 & 98 & 39 & 107. & 67 & 8.6780 \\
\hline $\mathrm{SC2}$ & $\mathrm{SC} 2$ & 46.4466 & 26 & 63. & 114 & 042 & 23.7883 \\
\hline $\mathrm{SC} 3$ & 2 & & 38 & & & & 5.0605 \\
\hline SC & & & & & & & 42 \\
\hline SC & & & & & 8 & & \\
\hline SC PVC & $\mathrm{C} 2$ & & & & & & \\
\hline P1 & --- & & & & & & \\
\hline P2 & --- & 28 & & & & & 6.7825 \\
\hline P3 & --- & & & & & & 13.8514 \\
\hline 4 & - & & & & & & \\
\hline P5 & - & & & & & & 72 \\
\hline P6 & --- & & & & & & 82 \\
\hline Li1U & --- & & & 68 & & & 40.7349 \\
\hline I & ---- & 56.1864 & 27. & 8.1801 & 61. & 36 & 40.1395 \\
\hline IUI & ---- & 47.3089 & 33.0367 & 6.7772 & 72.7127 & 49.3964 & 29.9458 \\
\hline $2 \mathrm{UI}$ & ---- & 38.2004 & 43.1280 & 15.6713 & 75.5275 & 52.9097 & 32.9044 \\
\hline $3 \mathrm{UI}$ & ---- & 28.4250 & 64.8759 & 36. & 82. & 32 & 31.2283 \\
\hline $4 \mathrm{UI}$ & ---- & 316 & 9.7917 & 6 & 81 & 41 & 35.7464 \\
\hline 101 & ---- & 130.8547 & 5.1354 & 101.9 & 29 & 192.7156 & 35.3408 \\
\hline ga2Ul & --- & 124.8178 & 92.6786 & 94.5820 & 5.6905 & 183.8445 & 127.7496 \\
\hline 301 & --- & 108.4265 & 64 & 55 & 28 & 30 & 125.8937 \\
\hline J & --- & 526 & 04 & 34 & & & \\
\hline ga5UI & --- & & & & 124.9970 & 429.1799 & 361.7213 \\
\hline & --- & 103.3171 & & & & & 114.9477 \\
\hline & --- & 152.6537 & & & & & 147.7067 \\
\hline SA1UI & ---- & 585.7692 & 453 & 468 & 187. & 67 & \\
\hline & --- & 40.7916 & & & & & \\
\hline 2UI & ---- & & & & & 20 & 17.8393 \\
\hline & ---- & & 48.2985 & 30.3600 & 112.5763 & 38.4665 & 4.4048 \\
\hline & ---- & 33.6483 & 56.3608 & 31.4648 & 133.0495 & 33.6582 & 2.6192 \\
\hline & ---- & 147.9581 & 138.4651 & & 224.4548 & 56.1016 & 59.8762 \\
\hline 6UI & --- & 53.9656 & 100.4686 & 57.1921 & 167.5251 & 49.4372 & 20.065 \\
\hline
\end{tabular}




\begin{tabular}{|c|c|c|c|c|c|c|c|}
\hline \multirow[b]{2}{*}{ Samples } & \multicolumn{7}{|c|}{$\begin{array}{c}\text { Posterior Probabilities (fprinttraceln1) } \\
\text { Incorrect classifications are marked with * }\end{array}$} \\
\hline & $\begin{array}{l}\text { Observed } \\
\text { Classif. }\end{array}$ & $\begin{array}{c}\mathrm{CH} \\
\mathrm{p}=.07895\end{array}$ & $\begin{array}{ll} & L 1 \\
p=.10526\end{array}$ & \begin{tabular}{c|}
$L 2$ \\
$p=.26316$
\end{tabular} & \begin{tabular}{c|} 
SA \\
$p=.21053$
\end{tabular} & $\begin{array}{c}\text { SC1 } \\
p=.15789\end{array}$ & $\begin{array}{c}\mathrm{SC2} \\
p=.18421\end{array}$ \\
\hline CH GS-7 & $\mathrm{CH}$ & 0.99999 & 0.00000 & 0.00000 & 0.00000 & 0.00000 & 0.00001 \\
\hline CH GS-12 & $\mathrm{CH}$ & 1.00000 & 0.00000 & 0.00000 & 0.00000 & 0.00000 & 0.00000 \\
\hline CH GS-16 & $\mathrm{CH}$ & 0.98841 & 0.00000 & 0.00000 & 0.00000 & 0.00000 & 0.01159 \\
\hline L 1A & L1 & 0.00000 & 1.00000 & 0.00000 & 0.00000 & 0.00000 & 0.00000 \\
\hline L 4A & L1 & 0.00000 & 0.75488 & 0.24512 & 0.00000 & 0.00000 & 0.00000 \\
\hline L 9A & L1 & 0.00000 & 0.99063 & 0.00937 & 0.00000 & 0.00000 & 0.00000 \\
\hline L10A & L1 & 0.00000 & 1.00000 & 0.00000 & 0.00000 & 0.00000 & 0.00000 \\
\hline L GS-2 & L2 & 0.00000 & 0.00011 & 0.99987 & 0.00000 & 0.00000 & 0.00002 \\
\hline L GS-4 & L2 & 0.00000 & 0.00000 & 0.99996 & 0.00000 & 0.00000 & 0.00004 \\
\hline L GS-10 & L2 & 0.00000 & 0.00001 & 0.99999 & 0.00000 & 0.00000 & 0.00000 \\
\hline LA & L2 & 0.00000 & 0.00000 & 1.00000 & 0.00000 & 0.00000 & 0.00000 \\
\hline L $3 A$ & L2 & 0.00000 & 0.00000 & 1.00000 & 0.00000 & 0.00000 & 0.00000 \\
\hline L 5A & L2 & 0.00000 & 0.00000 & 1.00000 & 0.00000 & 0.00000 & 0.00000 \\
\hline L 6A & L2 & 0.00000 & 0.00000 & 1.00000 & 0.00000 & 0.00000 & 0.00000 \\
\hline L 7A & L2 & 0.00000 & 0.00001 & 0.99999 & 0.00000 & 0.00000 & 0.00000 \\
\hline L $8 A$ & L2 & 0.00000 & 0.00000 & 1.00000 & 0.00000 & 0.00000 & 0.00000 \\
\hline L 11A & L2 & 0.00000 & 0.00000 & 0.99857 & 0.00000 & 0.00000 & 0.00143 \\
\hline SA GS-3 & SA & 0.00000 & 0.00000 & 0.00000 & 1.00000 & 0.00000 & 0.00000 \\
\hline SA GS-13 & SA & 0.00000 & 0.00000 & 0.00000 & 1.00000 & 0.00000 & 0.00000 \\
\hline SA GS-17 & SA & 0.00000 & 0.00000 & 0.00000 & 1.00000 & 0.00000 & 0.00000 \\
\hline SA GS-18 & SA & 0.00000 & 0.00000 & 0.00000 & 1.00000 & 0.00000 & 0.00000 \\
\hline SA PVC1 & SA & 0.00000 & 0.00000 & 0.00000 & 1.00000 & 0.00000 & 0.00000 \\
\hline SA PVC2 & SA & 0.00000 & 0.00000 & 0.00000 & 1.00000 & 0.00000 & 0.00000 \\
\hline SA PVC3 & SA & 0.00000 & 0.00000 & 0.00000 & 1.00000 & 0.00000 & 0.00000 \\
\hline SA GS-1 & SA & 0.00000 & 0.00000 & 0.00000 & 1.00000 & 000 & 0.00000 \\
\hline SC4 & SC1 & 0.00000 & 0.00000 & 0.00000 & 0.00000 & 000 & 0.00000 \\
\hline SC5 & SC1 & 0.00000 & 0.00000 & 0.00000 & 0.00000 & 0.97234 & 0.02766 \\
\hline SC 6 & SC1 & 0.00000 & 0.00000 & 0.00000 & 0.00000 & 1.00000 & 0.00000 \\
\hline SC9 & SC1 & 0.00000 & 0.00000 & 0.00000 & 0.00000 & 1.00000 & 0.00000 \\
\hline SC10 & SC1 & 0.00000 & 0.00000 & 0.00000 & 0.00000 & 1.00000 & 0.00000 \\
\hline SC11 & SC1 & 0.00000 & 0.00000 & 0.00000 & 0.00000 & 000 & 0.00000 \\
\hline SC GS-11 & SC2 & 0.00000 & 0.00000 & 0.00000 & 0.00000 & 0.00000 & 0.99999 \\
\hline SC GS-15 & SC2 & 0.00217 & 0.00000 & 0.00000 & 0.00000 & 0.00000 & 0.99783 \\
\hline SC2 & $\mathrm{SC} 2$ & 0.00001 & 0.00000 & 0.00000 & 0.00000 & 0.00000 & 0.99999 \\
\hline sc3 & SC2 & 0.00000 & 0.00000 & 0.00000 & 0.00000 & 0.00000 & 1.00000 \\
\hline SC7 & SC2 & 0.00000 & 0.00000 & 0.00000 & 0.00000 & 0.00000 & 1.00000 \\
\hline SC8 & SC2 & 0.00000 & 0.00000 & 0.00000 & 0.00000 & 0.00049 & 0.99951 \\
\hline SC PVC5 & $\mathrm{SC} 2$ & 0.00124 & 0.00000 & 0.00042 & 0.00000 & 0.00022 & 0.99812 \\
\hline P1 & --- & & 0.00000 & & $\overline{000}$ & & 0.00000 \\
\hline P2 & --- & & 00 & & & & \\
\hline P3 & --- & 0.0 & 0.00000 & 0.0 & 00 & 00 & 99 \\
\hline P4 & --- & 0.00000 & 0.00003 & 0.9 & 000 & 000 & 0.00000 \\
\hline P5 & --- & 0.00000 & 0.00000 & 0.99999 & 0.00000 & 0.00000 & 0.00001 \\
\hline P6 & --- & 0.00000 & 0.77098 & 0.21728 & 0.01173 & 0.00000 & 0.00000 \\
\hline Li1UI & --- & 0.00000 & 0.00000 & 1.00000 & 0.00000 & 0.00000 & 0.00000 \\
\hline Li2UI & --- & 0.00000 & 0.00003 & 0.99997 & 0.00000 & 0.00000 & 0.00000 \\
\hline at1Ul & --- & 0.00000 & 0.00000 & 0.99999 & 0.00000 & 0.00000 & 0.00001 \\
\hline at2UI & ---- & 0.00000 & 0.00000 & 0.99987 & 0.00000 & 0.00000 & 0.00013 \\
\hline at3UI & ---- & 0.60857 & 0.00000 & 0.04183 & 0.00000 & 0.00001 & 0.34959 \\
\hline at4UI & ---- & 0.00000 & 0.00000 & 1.00000 & 0.00000 & 0.00000 & 0.00000 \\
\hline ga1UI & ---- & 0.00000 & 0.00000 & 0.00000 & 1.00000 & 0.00000 & 0.00000 \\
\hline ga2UI & ---- & 0.00000 & 0.00000 & 0.00000 & 1.00000 & 0.00000 & 0.00000 \\
\hline ga3ul & ---- & 0.00000 & 0.00000 & 0.00000 & 1.00000 & 0.00000 & 0.00000 \\
\hline ga4UI & ---- & 0.00000 & 0.00000 & 0.00000 & 1.00000 & 0.00000 & 0.00000 \\
\hline ga5UI & --- & 0.00000 & 0.00000 & 0.00000 & 1.00000 & 0.00000 & 0.00000 \\
\hline ga6UI & ---- & 0.00000 & 0.00000 & 0.00000 & 1.00000 & 0.00000 & 0.00000 \\
\hline ga7UI & --- & 0.00000 & 0.00000 & 0.00000 & 1.00000 & 0.00000 & 0.00000 \\
\hline SA1UI & ---- & 0.00000 & 0.00000 & 0.00000 & 1.00000 & 0.00000 & 0.00000 \\
\hline SC1UI & ---- & 0.00002 & 0.00000 & 0.00098 & 0.00000 & 0.00000 & 0.99901 \\
\hline SC2UI & ---- & 0.00006 & 0.00000 & 0.00005 & 0.00000 & 0.00000 & 0.99989 \\
\hline SC3UI & --- & 0.00028 & 0.00000 & 0.00000 & 0.00000 & 0.00000 & 0.99972 \\
\hline SC4UI & ---- & 0.00000 & 0.00000 & 0.00000 & 0.00000 & 0.00000 & 1.00000 \\
\hline SC5UI & ---- & 0.00000 & 0.00000 & 0.00000 & 0.00000 & 0.84981 & 0.15019 \\
\hline Sc6UI & --- & 0.00000 & 0.00000 & 0.00000 & 0.00000 & 0.00000 & 1.00000 \\
\hline
\end{tabular}



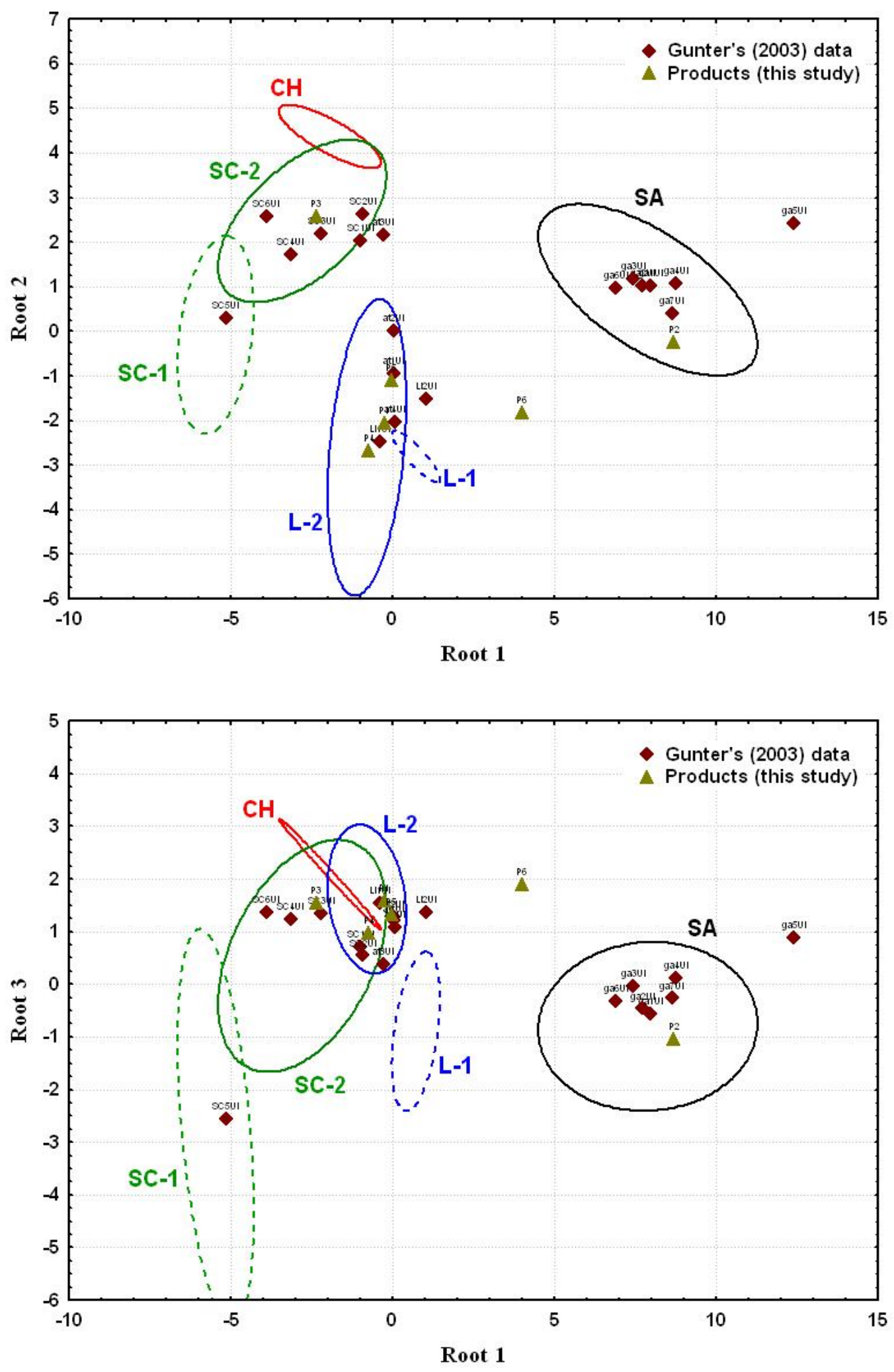

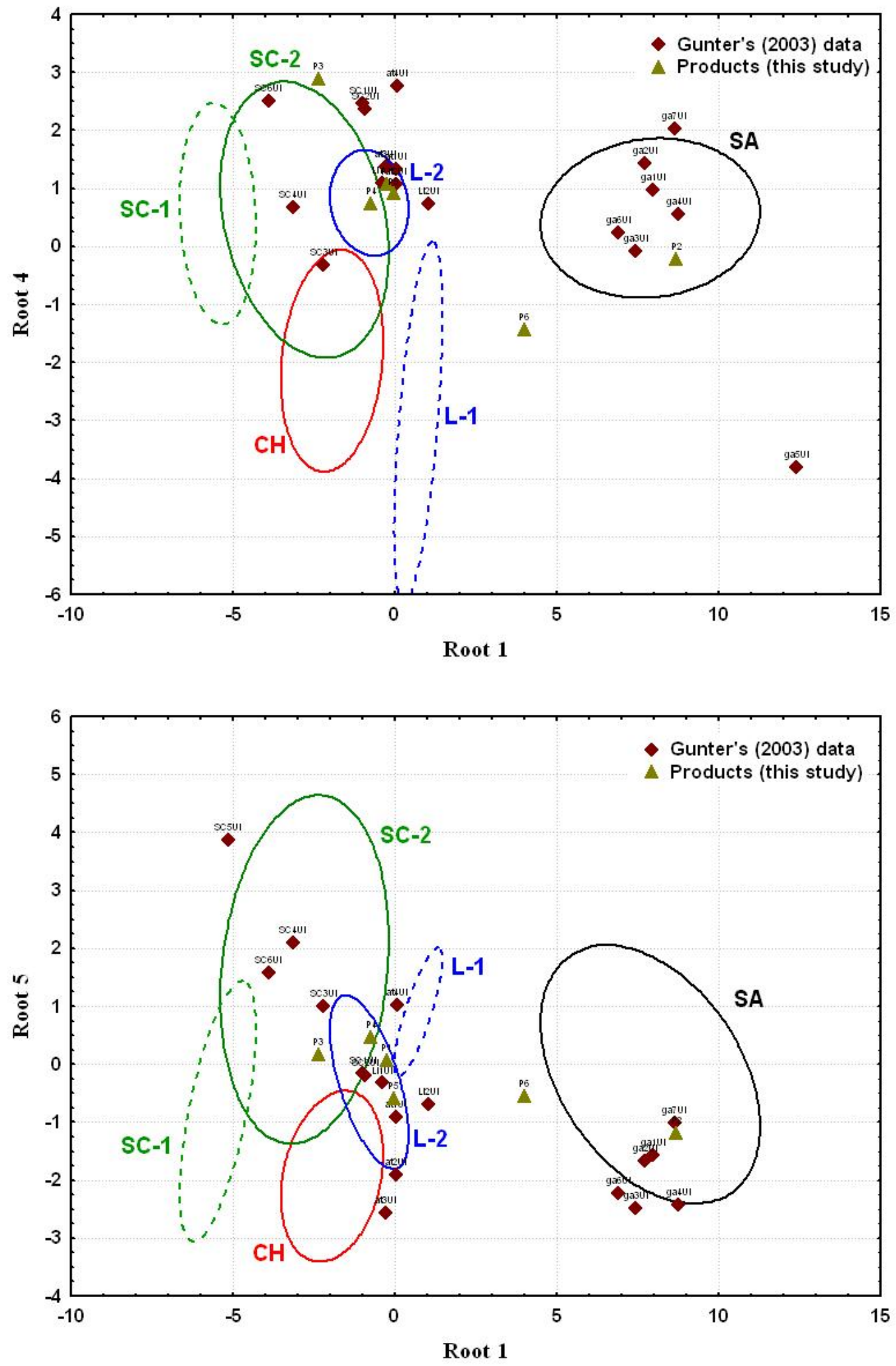

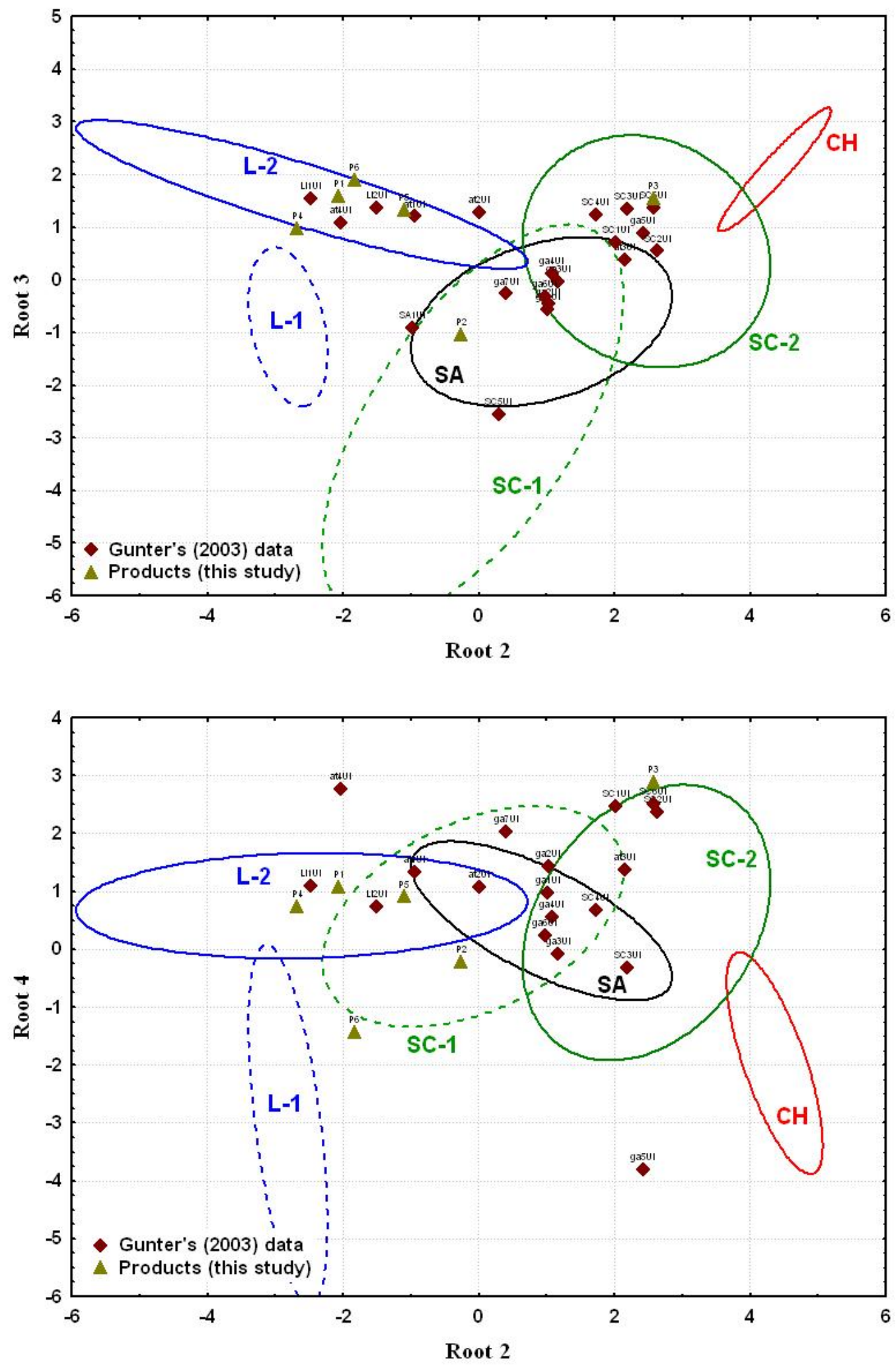

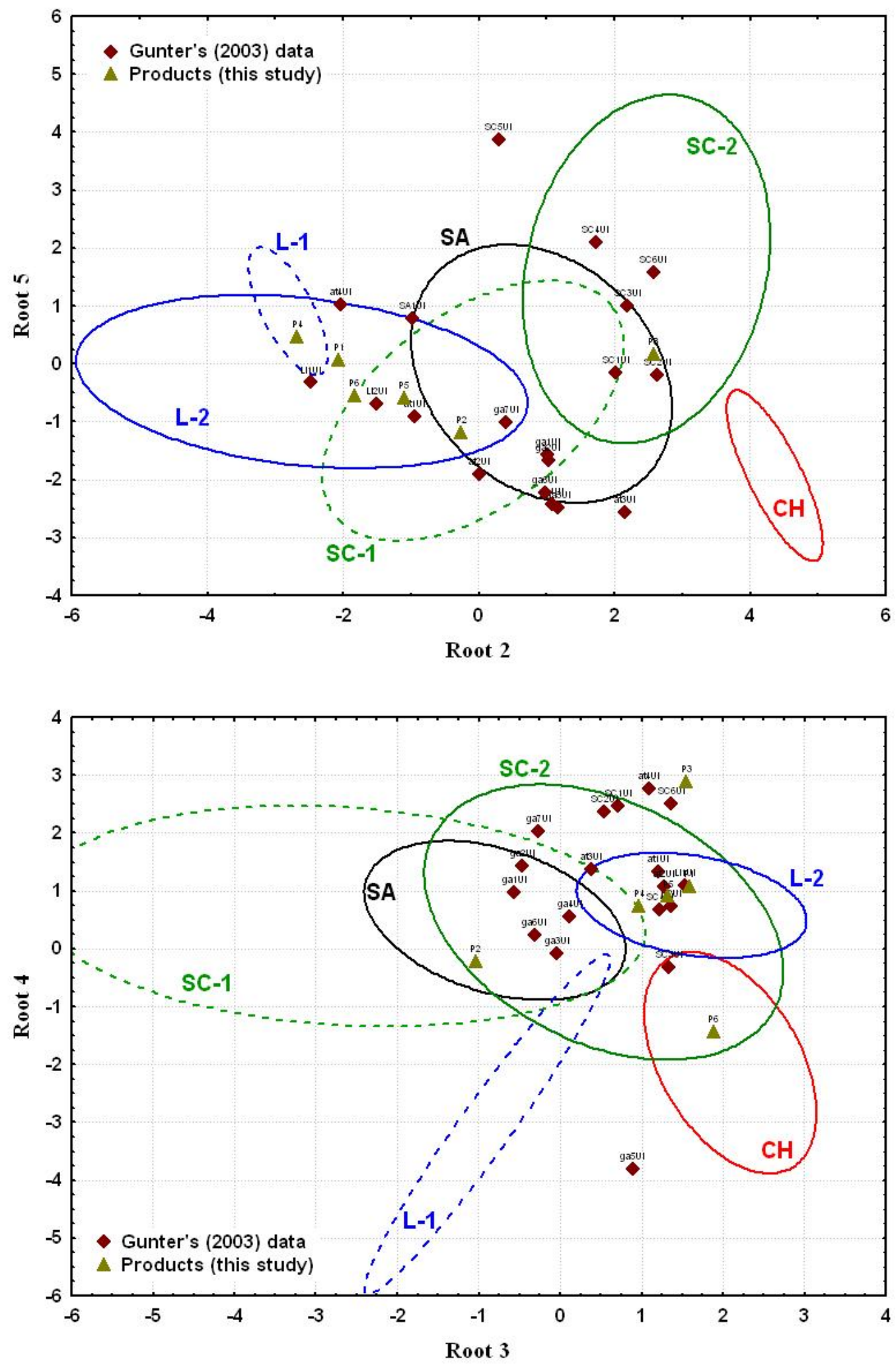

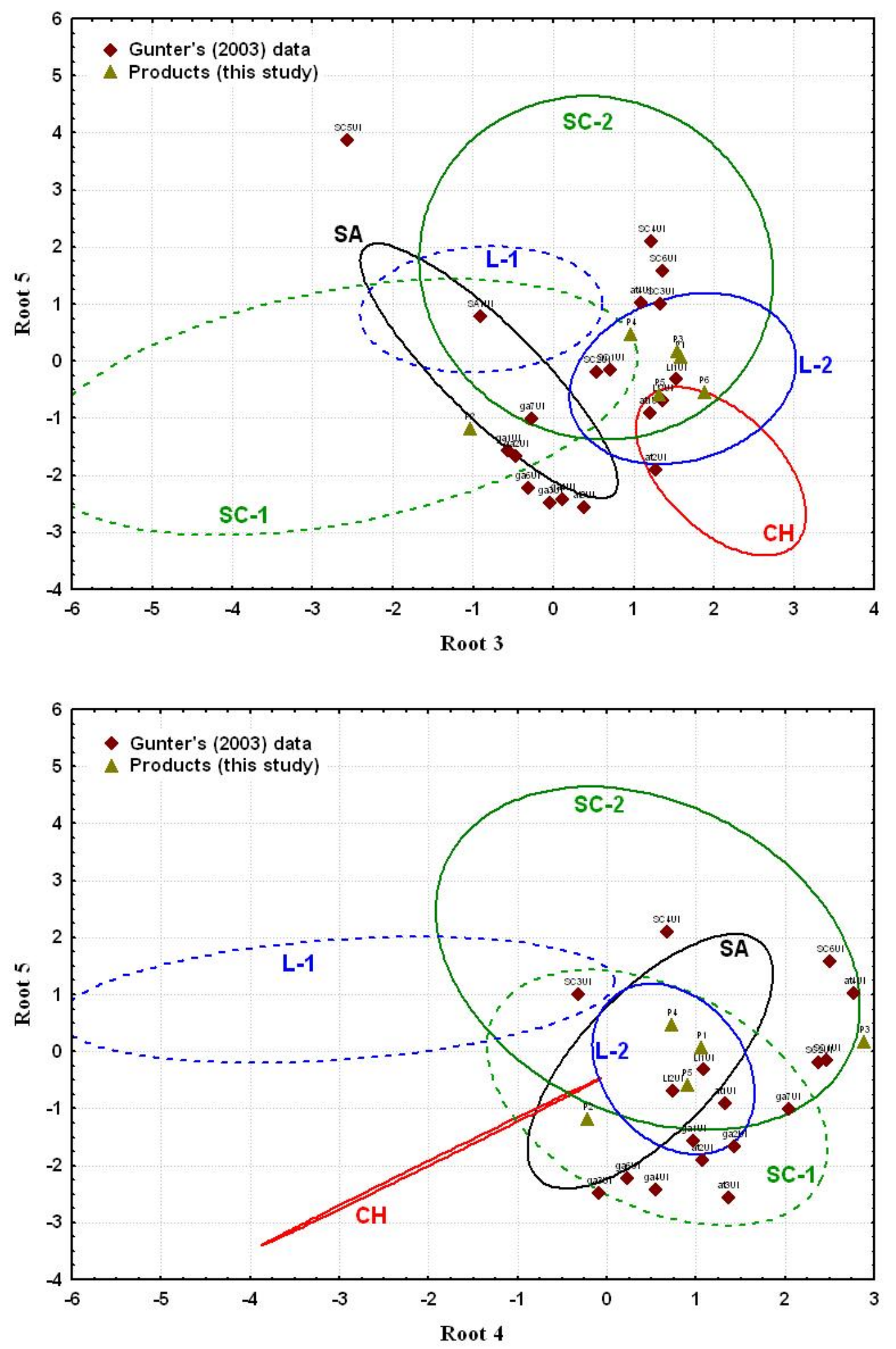